\begin{abstract}
UNIVERSIDADE DE SÃO PAULO (USP)
FACULDADE DE FILOSOFIA, LETRAS E CIÊNCIAS HUMANAS (FFLCH)

DEPARTAMENTO DE GEOGRAFIA (DG)

PROGRAMA DE PÓS-GRADUAÇÃO EM GEOGRAFIA HUMANA (PPGH)
\end{abstract}

ALEXANDRE DE CARVALHO TINOCO

Metropolização do espaço: o exemplo de Itaituba no Baixo Tapajós - PA

São Paulo

2019 


\author{
UNIVERSIDADE DE SÃO PAULO (USP) \\ FACULDADE DE FILOSOFIA, LETRAS E CIÊNCIAS HUMANAS (FFLCH) \\ DEPARTAMENTO DE GEOGRAFIA (DG) \\ PROGRAMA DE PÓS-GRADUAÇÃO EM GEOGRAFIA HUMANA (PPGH)
}

\title{
Metropolização do espaço: o exemplo de Itaituba no Baixo Tapajós - PA
}

Alexandre de Carvalho Tinoco

\section{Versão Original}

Tese apresentada ao Programa de Pós-Graduação em Geografia Humana do Departamento de Geografia Humana da Faculdade de Filosofia, Letras e Ciências Humanas da Universidade de São Paulo para obtenção de título de Doutor em Geografia Humana.

Orientadora: Prof ${ }^{\text {a. }}$ Dra. Sandra Lencioni.

\author{
São Paulo
}


Autorizo a reprodução e divulgação total ou parcial deste trabalho, por qualquer meio convencional ou eletrônico, para fins de estudo e pesquisa, desde que citada a fonte.

Catalogação na Publicação

Serviço de Biblioteca e Documentação

Faculdade de Filosofia, Letras e Ciências Humanas da Universidade de São Paulo

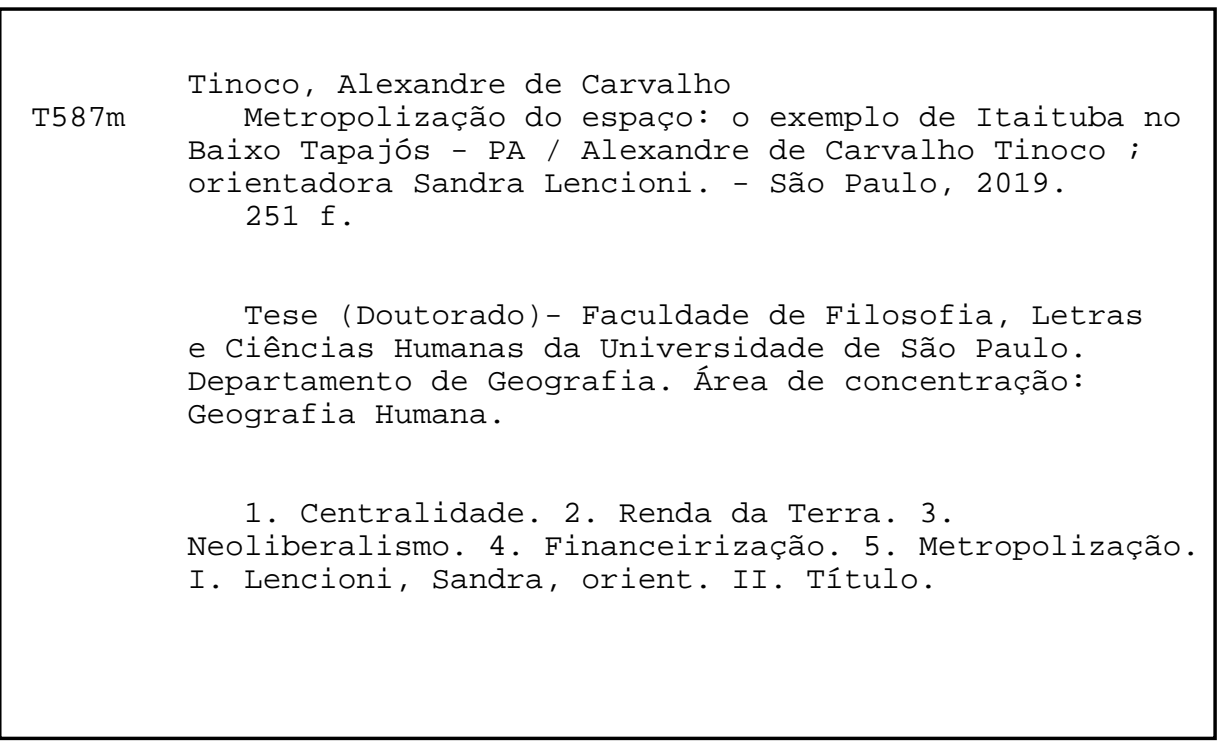


TINOCO, Alexandre de Carvalho. Metropolização do espaço: o exemplo de Itaituba no baixo Tapajós - PA. 2019. 251 f. Tese (Doutorado em Geografia Humana) - Programa de Pós-Graduação em Geografia Humana, Faculdade de Filosofia, Letras e Ciências Humanas, Universidade de São Paulo, São Paulo, 2019.

Aprovado em:

Banca Examinadora

Prof. Dr.

Instituição:

Julgamento:

Prof. Dr.

Instituição:

Julgamento:

Prof. Dr.

Instituição:

Julgamento: 
in memoriam, a Ivan Cruz Moura, com quem dividi tanto as pingas quanto os tombos desde os tempos de colégio, até os estudos em Paris. Que por questão de apenas um mês, não viu ganhar vida essa tese que sempre apoiou. 


\section{APRESENTAÇÃO E AGRADECIMENTOS}

Não. Esta tese não é sobre o baixo Tapajós. Também não é sobre Itaituba. Menos ainda sobre as enormes transformações pelas quais essa região vem passando no início do século XXI, a partir da consolidação do Arco Norte - conjunto de corredores logísticos que possibilitam a integração produtiva do agronegócio brasileiro às cadeias globais de produção de valor, em uma alternativa cerca de $40 \%$ mais barata do que a do escoamento dos produtos pelos portos do Sul e Sudeste do Brasil.

Esta tese também não é sobre o modo fordista de produção, muito menos sobre sua superação a partir da especialização flexível, da globalização e da financeirização da economia. Mas também não é sobre a hegemonia neoliberal que se instaura a partir de sua derrocada, definindo uma nova racionalidade para o mundo.

Também não é sobre a formação de cidades e suas redes, nem tampouco sobre as metrópoles decorrentes de uma urbanização fordista. E menos ainda sobre sua superação pelos processos de fragmentação e espraiamento que constituem as chamadas megarregiões, de onde se comandam as redes globais de produção de valor.

Esta tese também não é sobre a superação dos processos de urbanização fordista pelos de metropolização neoliberal como forma de compreendermos os processos de produção de espaço contemporâneo.

Esta tese quase não é uma tese.

Esta tese é sobre a relação existente entre cidade e valor. Esta tese é sobre o modo como a produção de valor produz cidades onde se produzem valores.

E como produção de valor que cria seu anti-valor, esta tese também produz sua anti-tese.

Uma tese que articula todos esses conceitos e assuntos sobre as quais ela não é.

Esta tese é apenas uma tese. 
Para que esta tese não deixasse de ser uma tese, várias pessoas contribuíram, e de forma bastante variada, na construção da trajetória que a tornou possível. E aqui gostaria de agradecer, iluminando o que de cada um há nesta tese.

Primeiro de tudo, a meus pais, Marta Maria Chagas de Carvalho e João Adolfo Hansen que, com afeto e acolhimento, me formaram intelectualmente, ensinando-me a pensar e a inquirir. Deles recebi todo o estímulo para ir buscar diálogos distantes, fosse em Belo Horizonte, Paris ou Belém, apesar das distâncias e ausências que disso decorreram. Deles recebi todo o apoio quando essa trajetória se mostrou difícil e em risco. Deles vem a base, além de leituras, críticas e preciosa revisão.

A partir de instigantes discussões com o Professor Dr. Paul Singer, quando da realização de meu trabalho de final de curso e de seu curso sobre a Moeda, na Faculdade de Economia da USP, me interessei em buscar compreender as origens do valor na sociedade capitalista. Desde então, essa busca por diálogos entre várias linhas de pesquisa e correntes teóricas, que marcaram a trajetória desta tese, se evidenciou, quando decidimos compreender em Georg Simmel, a partir de seu Filosofia do dinheiro, de 1908, a relação entre dinheiro e valor.

Desde a realização de meu mestrado, terminado em 2001 no CEDEPLAR-UFMG, pude compartilhar minha trajetória com os Professores Drs. Mauro Borges Lemos e Clélio Campolina Diniz - então meu orientador. Com o professor Mauro aprendi os rigores e a importância dos rendimentos crescentes para os processos aglomerativos e de crescimento econômico. Do professor Campolina ouvi, repetidas vezes, que precisávamos parar de "amassar barro" acerca dos estudos sobre o processo de desconcentração industrial da Região Metropolitana de São Paulo e que seria necessário procurarmos novas abordagens de análise para compreender esses movimentos à luz das transformações estruturais da sociedade contemporânea.

Com ambos pude compartilhar ótimos momentos de reflexão quando da passagem deles por Paris, por ocasião de seus pós-doutoramentos. Da exigência do rigor no tratamento das correntes de pensamento da economia 
regional, que se desdobravam desde o final da década de 1990 com um deles, até o alargamento do espectro explicativo do impacto das transformações estruturais do capitalismo contemporâneo nas dinâmicas metropolitanas, com outro. Com ambos consolidei a questão com a qual, meio que sem querer, vim me reencontrar neste doutoramento na Geografia Humana da USP.

Da passagem por Paris retenho as inspiradoras reflexões e discussões ocorridas durante o curso com o Professor Dr. Jacques François Thisse, na École nationale de la statistique et de l'administration économique (ENSAE), cuja capacidade de contextualizar histórica e geograficamente a importância e o significado de betas, alfas e ômegas das equações dos modelos da Nova Geografia Econômica é inspiradora e me permitiu conectar intelectualmente correntes teóricas distintas na explicação do fenômeno da metropolização.

Aproveitando para corrigir um erro quando da finalização de meu mestrado, onde não inseri na versão depositada os agradecimentos, gostaria de reconhecer e agradecer a meus colegas de Programa de Formação de Quadros Profissionais do CEBRAP, turma de 1999/2001, com quem compartilhei os primeiros escritos desta longa reflexão. De Cláudio Roberto Amitrano, com quem formava a dupla de intrépidos economistas do grupo, recebi sempre o reforço da leitura keynesiana e sua importância para compreendermos a sociedade que, então, se desestruturava. As inquietações e questionamentos do sociólogo Celso Rocha de Barros sempre me obrigaram a buscar outra explicação, sempre avançando na complexidade dos fenômenos analisados. Por último, com o cientista político Adrián Gurza Lavalle, compartilhei possivelmente as discussões mais ricas, construtivas e rigorosas que pude ter na consolidação desta problemática, que culminou na elaboração de minha dissertação e no projeto de doutoramento junto à Universidade de Paris XI. Aos três sou bastante grato pela contribuição nesta trajetória e feliz de ter, com eles, compartilhado a amizade e o conhecimento.

Nos mais de 10 anos dedicados à consultoria na área de planejamento urbano e territorial e meio ambiente tanto no Brasil, quanto no Exterior (Moçambique, Guiné, Indonésia, Colômbia e Chile), compartilhei com inúmeros colegas o estudo do impacto de grandes empreendimentos em seus territórios de implantação e a proposição de alternativas de enfrentamento. 
Desta experiência trago comigo a compreensão da violência do capital. Violência em todos os níveis e todas as esferas. Seja a violência física - que começa, por exemplo, no rasgar da terra para a extração, à força, de milhões de toneladas de ferro por ano, arrancando junto com o minério todo o equilíbrio hidrogeológico e ecossistêmico de uma região; seja a violência direta de comunidades impactadas das mais diversas formas, que perdem acesso a recursos, que perdem vínculos com territórios, e às quais é dificultada a possibilidade do viver; seja a violência política e institucional, devido à força com que o capital se apropria da coisa pública e a desvirtua.

Nesta tese não tratarei desses impactos. Venho falando, buscando e negociando estratégias de mitigação e compensação deles há mais de 10 anos. Mas gostaria de que todas as vezes em que a palavra capital for lida no decorrer das próximas páginas, o leitor se lembre dessa violência. Ela nunca deve ser esquecida. E me desculpem, porque essa palavra se repete 293 vezes nesta tese.

Do trabalho com consultoria amadureci um segundo projeto de doutorado sobre o processo de redução da extrema pobreza no Estado do Piauí, durante a primeira década deste século. Foi com esse projeto que entrei no doutorado na Geografia Humana da USP. Para minha surpresa, acabei sendo "alocado" com a Professora Dra. Sandra Lencioni, com quem compartilhava as preocupações iniciais de pesquisa de meu mestrado e de meu primeiro doutoramento, mas que eu imaginava que não se interessasse em discutir o projeto entregue. Ela nunca me sugeriu nem indicou a possibilidade de mudança de tema, no sentido de retornar para a temática da metropolização, tão cara a mim e tão tributária a ela.

Fomos avançando leituras e segui suas sugestões quanto aos créditos a cumprir. As matérias dos professores Paulo César Xavier Pereira (FAU-USP) e Ana Fani Alessandri Castro (PPGH-USP) reativaram o interesse pelo estudo das grandes cidades mundiais e pelo processo de metropolização, fornecendo as bases da reflexão desenvolvida nesta tese. Mas a reconversão ainda não se havia operado.

Foi necessária mais uma etapa de meu trabalho profissional, enquanto Coordenador das ações da ONU-Habitat no Estado do Pará, em um projeto 
que buscava contribuir com o Estado na elaboração de políticas públicas de desenvolvimento urbano sustentável para as regiões impactadas por grandes empreendimentos para que eu entrasse, definitivamente, em contato com Itaituba.

Quando, mais uma vez, as preocupações acadêmicas se encontraram com minha atividade profissional, tive a ideia de sugerir à Professora Sandra mudar de tema e defendermos a qualificação sobre o "impacto de grandes empreendimentos na rede de cidades do baixo Tapajós". Confesso que, à época, tive receio de sua reação. Hoje, imagino que um "tava demorando" deve ter passado por sua cabeça.

E foi assim, com esse novo projeto, que fui para a qualificação, elaborada quando eu ainda estava morando em Belém.

E não foi uma surpresa que um dos principais questionamentos que recebi se referia à qual conceito de centralidade eu estava recorrendo. Tanto a Professora Dra. Glória da Anunciação Alves quanto o Prof. Dr. César Ricardo Simoni Santos me fizeram a mesma observação que os professores Mauro Borges e Roberto Luis Monte-Mór fizeram na banca de meu mestrado, a de que precisava reforçar a reflexão que fazia sobre a centralidade (e suas mutações) de cidades, sejam elas São Paulo, Itaituba ou Santarém. Pra completar, O Professor Dr. Saint-Clair, para quem eu mandei a qualificação, me fez, dentre outras contribuições, o mesmo questionamento.

Foi dessa forma que praticamente todos os momentos de minha trajetória intelectual e profissional convergiram para o tema principal desta tese, a discussão do teor dessa centralidade no mundo contemporâneo, entendendo que é justamente esse conceito que une as noções de cidade e valor.

Neste processo, as ricas reflexões no âmbito dos colóquios mensais do Laboratório de Estudos Regionais em Geografia (LERGEO) - USP, formado por orientandos da Profa. Sandra, contribuíram, em muito, para que chegasse à compreensão de que deveria incorporar definitivamente a abordagem sobre a metropolização para meu objeto de estudo, a implantação de grandes empreendimentos no baixo Tapajós. 
E, por fim, foi justamente a partir da compreensão do aspecto globalizado e financeirizado desses empreendimentos, comandados em grande parte a partir da cidade de São Paulo, que o ciclo se fechou e foi possível argumentar sobre um tipo específico de centralidade contemporânea que conecta o desenvolvimento urbano de Itaituba com o de São Paulo, como expressão da chamada metropolização do espaço.

Terminado esse caminho, gostaria de registrar um profundo agradecimento à Professora Sandra pelo acolhimento, por ter dado o espaçotempo necessário para que eu reencontrasse esse caminho e partisse para o encerramento desse longo ciclo. Sem ela o fluxo não seria retomado. E, sem o fluxo, o devir não se apresenta como realizável.

Dentre os colegas de trabalho, gostaria de registrar um agradecimento especial ao Marcos Martines, sobretudo por ter sido o grande incentivador para que eu me decidisse por concorrer a uma vaga no doutorado da Geografia, onde ele também fez o dele, e também por ter me ajudado com a elaboração dos mapas aqui presentes. Outro agradecimento especial vai para minha colega de trabalho e de pesquisa Martha Malheiro, que acompanho desde estagiária. Participei da banca de seu trabalho de final de curso e com ela tenho compartilhado reflexões teóricas e conceituais, bem como uma trajetória profissional.

Por fim, há o agradecimento de vida. Um agradecimento especial à duplinha com quem compartilho todos os momentos e que iluminou esse caminho.

À Kellen, agradeço por me doar a crença de que sempre seria possível. Por ter apoiado os diversos momentos críticos dessa caminhada, por ser uma inspiração de competência, inteligência e força de vontade. Por ter acendido a luz desse caminho.

À Dora agradeço por ser a luz. Sua alegria multiplica as possibilidades do ser. Seu interesse pelo mundo aguça o espírito explicativo. Sua abertura para o mundo faz de sua conquista um horizonte.

À Dora agradeço também o primeiro mapa desta tese. Quando comigo foi para o Rio Tapajós, na delícia de seus 6 anos de idade, me ouviu horas a fio 
explicar o que nele me intrigava. Para minha surpresa, quando fui à exposição de artes de final de ano na escola dela, fui presenteado com o primeiro esboço da tese, um desenho do Rio Tapajós conectando dia e noite o Brasil com a China maravilhada com os botos cor-de-rosa.

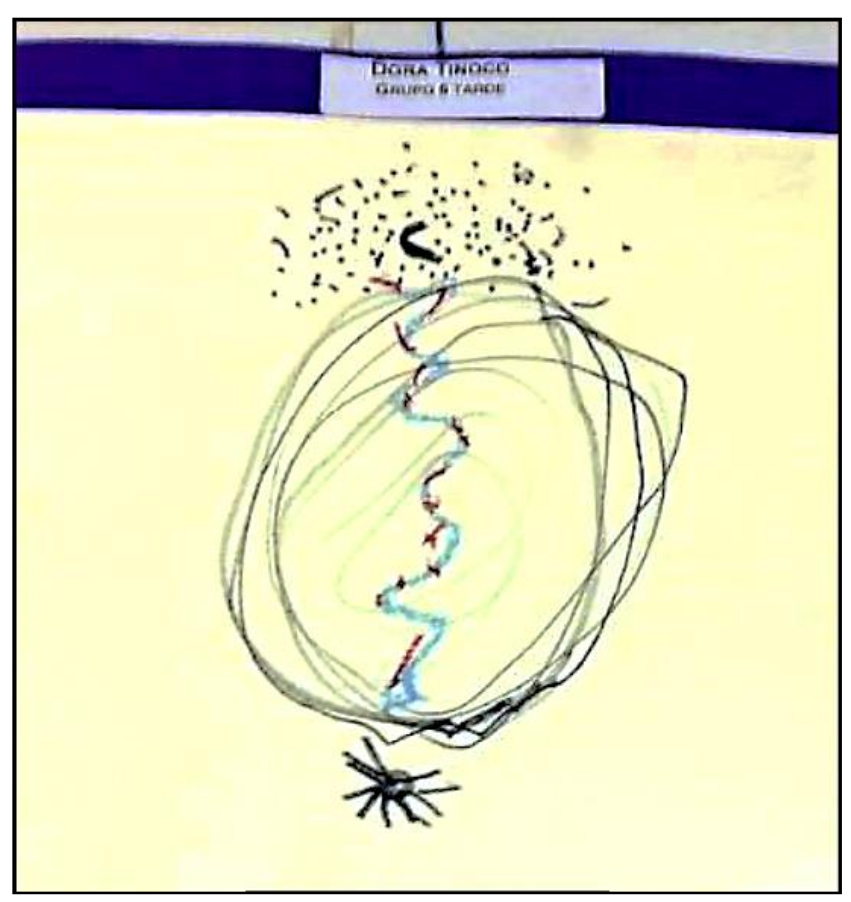




\section{RESUMO}

TINOCO, Alexandre de Carvalho. Metropolização do espaço: o exemplo de Itaituba no baixo Tapajós - PA. 2019. 251 f. Tese (Doutorado em Geografia Humana) - Programa de Pós-Graduação em Geografia Humana, Faculdade de Filosofia, Letras e Ciências Humanas, Universidade de São Paulo, São Paulo, 2019.

A produção do espaço na sociedade contemporânea resulta da interação entre diversas condicionantes históricas e novos processos que operam uma ruptura entre 0 que podemos chamar de sociedade moderna e sociedade contemporânea. A resultante dessa interação, longe de ser um padrão homogêneo, é diversa e desigual. No entanto, essa desigualdade não impede que identifiquemos no processo de cisão da centralidade contemporânea, entendida como a não obrigatoriedade de coincidência espacial entre processos de concentração e centralização de capital, o mecanismo base que opera a metropolização do espaço, compreendido aqui como processo de formação das chamadas Megarregiões, a partir de onde se organiza a rede mundial de cidades, concomitantemente ao espraiamento, desigual, do padrão metropolitano para as cidades que são conectadas a essa rede.

Identificamos no que chamamos de período metropolitano-neoliberal, como especificidade histórica capitalista da contemporaneidade, o momento em que essa cisão da centralidade se opera de forma hegemônica, por ser grandemente interligada à globalização, à financeirização e à hegemonia da racionalidade neoliberal em todas as esferas da vida pública e privada.

Nesta tese percorremos elementos históricos, teóricos e empíricos que visam argumentar que o processo contemporâneo de produção do espaço está marcado pela metropolização-neoliberal, em contraste com os processos de urbanização-fordista que marcaram a segunda metade do século XX e consolidaram as metrópoles como forma urbana típica desse período.

A análise empírica se baseia na avaliação da contribuição que os investimentos em logística de escoamento da produção de grãos da agropecuária brasileira, via consolidação do chamado Corredor Logístico do Tapajós, em Itaituba-PA, tem para a consolidação de uma cadeia de produção de valor globalizada e financeirizada. A partir da importância que fundos de investimentos têm na alocação de capital fixo nessa região, seja diretamente via participação acionária, ou mediados pelas sedes das empresas de tradings, pudemos identificar a rede de cidades mundiais que estruturam essa cadeia produtiva e esses investimentos no baixo Tapajós.

Desta identificação, a megarregião de São Paulo se sobressai comandando o processo de metropolização do espaço do baixo Tapajós, uma vez que mais de $40 \%$ desses investimentos se originam ou passam por ela.

Palavras-chave: Metropolização do espaço. Renda da terra. Neoliberalismo. Centralidade. Financeirização. 


\begin{abstract}
TINOCO, Alexandre de Carvalho. Metropolization of space: the example of Itaituba in the lower Tapajós - PA. 2019. $251 \mathrm{f}$. Tese (Doutorado em Geografia Humana) - Programa de Pós-Graduação em Geografia Humana, Faculdade de Filosofia, Letras e Ciências Humanas, Universidade de São Paulo, São Paulo, 2019.

The production of space in contemporary society results from the interaction of several historical constraints and new processes that operate a rupture between what we can call modern society and contemporary society. The result of this interaction, far from being a homogeneous pattern, is diverse and unequal. However, this inequality does not prevent us from identifying in the process of Division of contemporary centrality, understood as the non-mandatory spatial coincidence of processes of concentration and Centralization of capital, the basic mechanism that operates the metropolization of space, understood here as a process of formation of the so called megarregions, from where the world network of cities is organized, concomitant to the unequal metropolitan pattern of the cities that are connected to this network.
\end{abstract}

We identify in what we call the Metropolitan-neoliberal period, as a historical capitalist specificity of contemporaneity, the moment when this division of centrality operates in a hegemonic way, because it is largely interconnected with globalization, financialization and the hegemony of neoliberal rationality in all spheres of public and private life.

In this thesis we have covered historical, theoretical and empirical elements that aim to argue that the contemporary process of production of space is marked by metropolization-neoliberal pattern instead of the processes of Fordist urbanization that marked the second half of the twentieth century and consolidated the metropolises as the typical urban form of this period.

The empirical analysis is based on the evaluation of the contribution of the investments in logistics to yield the grain production of Brazilian agriculture, through consolidation of the so-called logistics corridor of Tapajós, in Itaituba$\mathrm{PA}$, for the consolidation of a production chain of globalized and financialized value. From the importance that investment funds have in the allocation of fixed capital in this region, either directly via shareholding, or brokered by the headquarters of trading companies, we were able to identify the network of cities structuring this production chain and these investments in the lower Tapajós.

In this identification, the megarregion of São Paulo stands out commanding the process of metropolization of the space of the low Tapajós, since more than $40 \%$ of these investments originate from it or pass through it.

Keywords: Metropolization of Space. Land Rent. Neoliberalism. Centrality. Financialization. 


\section{RÉSUMÉ}

TINOCO, Alexandre de Carvalho. Métropolisation de l'espace: l'exemple d'Itaituba dans le Bas Tapajós - PA. 2019. 251 f. Tese (Doutorado em Geografia Humana) - Programa de Pós-Graduação em Geografia Humana, Faculdade de Filosofia, Letras e Ciências Humanas, Universidade de São Paulo, São Paulo, 2019.

La production de l'espace dans la société contemporaine résulte de l'interaction entre plusieurs contraintes historiques et de nouveaux processus qui opèrent une rupture entre ce que nous pouvons appeler la société moderne et la société contemporaine. Le résultat de cette interaction, loin d'être un modèle homogène, est diversifié et inégalitaire. Cependant, cette inégalité ne nous empêche pas d'identifier dans le processus de division de la centralité contemporaine, comprise comme la coïncidence spatiale non obligatoire entre les processus de concentration et de centralisation du capital, le mécanisme de base qui exploite la métropolisation de l'espace, comprise ici comme un processus de formation des mégarrégions, d'où le reseau mondial des villes est organisé, en même temps que le modèle inégal, métropolitain, pour les villes qui sont connectées à ce réseau.

Nous identifions dans ce que nous appelons la période métropolitainenéolibérale, comme une spécificité capitaliste historique de la contemporanéité, le moment où cette division de la centralité fonctionne d'une manière hégémonique, parce qu'elle est fortement liée à la mondialisation, à la financiarisation et à l'hégémonie de la rationalité néolibérale dans tous les domaines de la vie publique et privée.

Dans cette thèse, nous avons examiné des éléments historiques, théoriques et empiriques qui visent à faire valoir que le processus contemporain de production de l'espace est marqué par la métropolisation-néolibérale, en contraste avec les processus d'urbanisation-fordiste qui ont marqué la seconde moitié du 20 ème siècle et ont consolidé les métropoles comme une forme urbaine typique de cette période.

L'analyse empirique est basée sur l'évaluation de la contribution que les investissements dans la logistique de l' écoulement de la production céréalière de l'agriculture brésilienne par la consolidation du Corridor Logistique du Tapajós, à Itaituba-PA, a pour la consolidation d'une chaîne de production de valeur mondialisée et financialisée. D' après l'importance que les fonds d'investissement ont dans l'allocation de capital fixe dans cette région, soit directement par actionnariat, soit négocié par les sièges des sociétés de négoce, nous avons pu identifier le réseau de villes mondiales qui structurent cette chaîne de production et ces investissements dans le bas Tapajós.

D' après cette identification, la mégarrégion de Sao Paulo se distingue commandant le processus de métropolisation de l'espace du bas Tapajós, puisque plus de $40 \%$ de ces investissements proviennent d'elle ou passent par elle.

Mots-clés: Métropolisation de l'espace. Rente Foncière. Néolibéralisme. Centralité. Financiarisation. 


\section{LISTA DE FIGURAS}

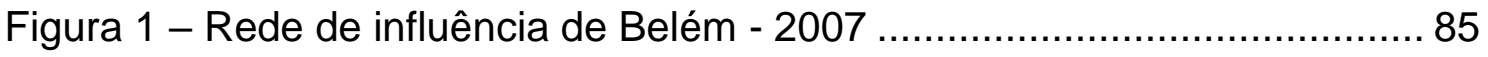

Figura 2 - Interações espaciais de Santarém - PA ..................................... 86

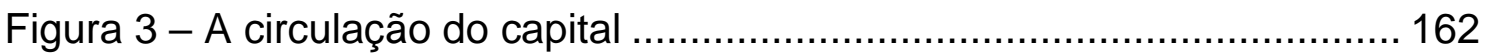

Figura 4 - Capacidade de escoamento de grãos pelo Arco Norte................. 203

Figura 5 - Localização das ETCs existentes na margem direita do rio Tapajós,

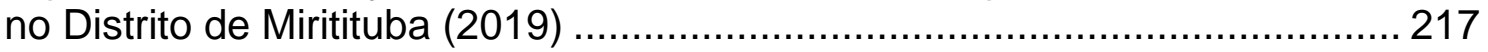

Figura 6 - Foto aérea da ETC da Bunge, Miritituba ...................................... 221

Figura 7 - Foto aérea da ETC da Hidrovias do Brasil, Miritituba .................... 223

Figura 8 - Foto aérea da ETC da Cianport, Miritituba.................................. 224

Figura 9 - Foto aérea da ETC da Cargill, Miritituba ..................................... 225

Figura 10 - Foto aérea com indicativo de instalação de quatro novas ETCs, a

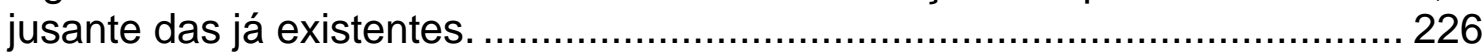




\section{LISTA DE TABELAS}

Tabela 1 - Área territorial e população dos municípios pertencentes à RI do

Tapajós 72

Tabela 2 - Produto Interno Bruto a preços correntes (Mil Reais) dos municípios que compõem a Região de Integração do Tapajós - RIT 76

Tabela 3 - Características da redes de cidades de primeiro nível - 2007 ........ 84

Tabela 4 - Participação dos investimentos previstos por município 198

Tabela 5 - Participação dos investimentos previstos por origem do capital .. 216 


\section{LISTA DE MAPAS}

Mapa 1 - Limites da Região de Integração do Tapajós ................................... 71

Mapa 2 - Corredor Logístico do Tapajós .................................................... 192

Mapa 3 - Rotas de exportação de grãos a partir do baixo Tapajós ................ 199

Mapa 4 - Origem de capital do investimento no baixo Tapajós - conexões

diretas, por percentual do investimento total (2017)..................................... 230

Mapa 5 - Origem de capital do investimento em Itaituba por tipo de conexão (2017) 


\section{LISTA DE GRÁFICOS}

Gráfico 1 - Evolução da população rural e urbana da RI Tapajós 75

Gráfico 2 - Proporção do Produto Interno Bruto a preços correntes (Mil Reais) de Itaituba em relação a sua RIT e a RIT em relação ao Estado do Pará - entre os anos de 2002 a 2016

Gráfico 3 - Distribuição dos investimentos previstos por etapa do processo de licenciamento ambiental....

Gráfico 4 - Participação acionária na Bunge - julho de 2019........................ 218

Gráfico 5 - Variação diária da cotação das ações da Bunge (BG) na NYSE de out/14 a set/19. 219

Gráfico 6 - Variação diária da cotação das ações da Price T. Rowe (TROW) na NYSE de out/14 a set/19. 219

Gráfico 7 - Composição acionária da Hidrovias do Brasil S.A....................... 222

Gráfico 8 - Composição acionária da Cianport - 2019 ................................. 224

Gráfico 9 - Cidade de origem dos investimentos em Santarém - em participação percentual no total de investimentos no baixo Tapajós - 2017 .. 231

Gráfico 10 - Cidade de origem dos investimentos em Itaituba e Rurópolis - em participação percentual no total de investimentos no baixo Tapajós - 2017 .. 232 


\section{LISTA DE SIGLAS E ABREVIATURAS}

ABCD - ADM, Bunge, Cargill e Dreyfus

ADM - Archer Daniels Midland

ANTAQ - Agência Nacional de Transportes Aquaviários

BNDESPAR - Banco Nacional de Desenvolvimento Econômico e Social Participações

BG - Sigla da Bunge na NYSE

CC - Carta Consulta

CEBRAP - Centro Brasileiro de Análise e Planejamento

CEDEPLAR - Centro de Desenvolvimento e Planejamento Regional

Cianport - Companhia Norte de Navegação e Portos

CSA - Ciclo Sistêmico de Acumulação

EIA - Estudos de Impacto Ambiental

Embraps - Empresa Brasileira de Portos de Santarém

ENSAE - École nationale de la statistique et de l'administration économique

ETC - Estação de transbordo de carga

EUA - Estados Unidos da América

FADESP - Fundação de Amparo e Desenvolvimento da Pesquisa

FAU- Faculdade de Arquitetura e Urbanismo

FGTS - Fundo de Garantia por Tempo de Serviço

HERMASA - Empresa de Navegação da Amazônia

IBGE - Instituto Brasileiro de Geografia e Estatística

IDESP - Instituto de Desenvolvimento Econômico, Social e Ambiental do Pará

INCRA - Instituto Nacional de Colonização e Reforma Agrária

IFC - International Finance Corporation

LDC - Louis Dreyfus Company

LERGEO - Laboratório de Estudos Regionais em Geografia

LI - Licença de Implantação

LO - Licença de Operação

LP - Licença Prévia

MAPA - Ministério da Agricultura, Pecuária e Abastecimento

MTPA - Ministério dos Transportes, Portos e Aviação Civil

NEG - Nova Geografia Econômica

NYSE - New York Stock Exchange 
ONU-Habitat - Organização das Nações Unidas - Programa das Nações Unidas para os Assentamentos Humanos

OTP - Odebrecht Transport

P\&D - Pesquisa e Desenvolvimento

PAC - Programa de Aceleração de crescimento

PDP - de Desenvolvimento Produtivo

PIB - Produto Interno Bruto

PIC - Programa Integrado de Colonização

PIL - Plano Infraestrutura Logística

PIN - Plano de Integração Nacional

PNLP - Plano Nacional Logística Portuária

PPGH - Programa de Pós-Graduação em Geografia Humana

PORTOBRAS - Empresa de Portos do Brasil

PROTERRA - Programa de Redistribuição de Terras e de Estímulos à Agroindústria do Norte e do Nordeste

REGIC - Regiões de Influência das Cidades

RI - Região de Integração

RIT - Região de Integração do Tapajós

SEMAS - Secretaria de Meio Ambiente e Sustentabilidade do Pará

SUDAM - Superintendência do Desenvolvimento da Amazônia

TERFRON - Terminal Portuário Fronteira Norte

TI - Tecnologia de Informação

TR - Termo de Referencia

TROW - Sigla da Bunge na NYSE

TUP - Terminais de Uso Privado

UFMG - Universidade Federal de Minas Gerais

UHE - Usina Hidrelétrica de Energia

USA - United States of America

USDA - United States Departament of Agriculture

USP - Universidade de São Paulo 


\section{Sumário}

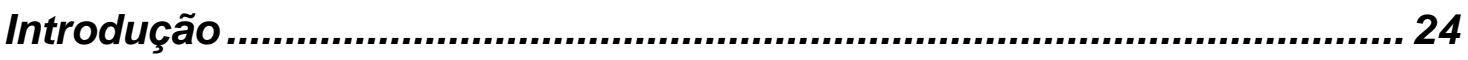

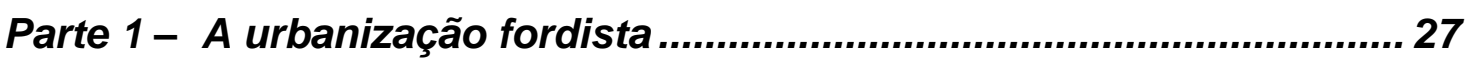

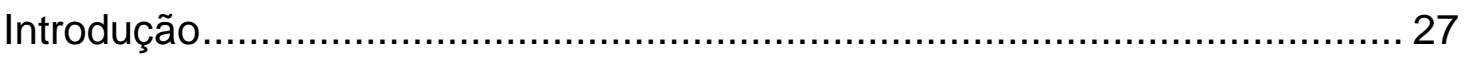

1.1 A crise Liberal e o novo mundo Keynesiano........................................... 28

1.2 A estruturação do espaço regionail na virada do mundo liberal para uma

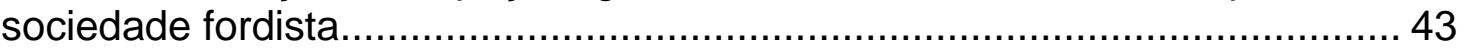

1.2.1 A Metrópole como fenômeno da urbanização fordista........................... 63

1.3 Itaituba e o baixo Tapajós no final do século XX ...................................... 67

1.3.1 Breve contextualização histórica do baixo Tapajós .................................. 68

1.3.2 O contexto territorial da Região de Integração do Tapajós na segunda metade do século XX

1.3.3 Características socioeconômicas da Região de Integração Tapajós..... 74

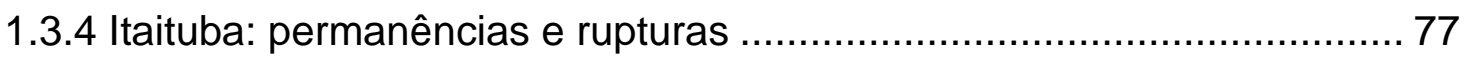

1.3.4.1 Itaituba e seu momento urbano-fordista ......................................... 79

1.4 Itaituba hoje e novos desafios teórico-metodológicos .............................. 88

Parte 2 - Da urbanização fordista à metropolização neoliberal ................ 92

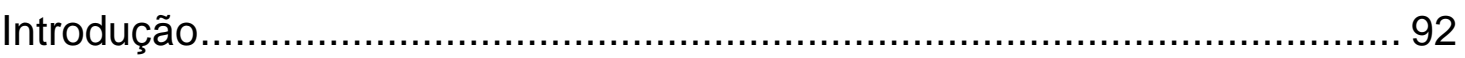

2.1 A crise do fordismo e sua superação pelo neoliberalismo ......................... 94

2.1.1 A constituição de uma sociedade em rede ...................................... 100

2.1.2 Globalização e urbanização sob a racionalidade neoliberal ................ 103

2.1.3 Os reflexos na centralidade dos lugares........................................... 118

2.1.4 A centralidade na era metropolitano-neoliberal ................................ 120

2.2 A estruturação do espaço regional e urbano no pós-fordismo ................ 124

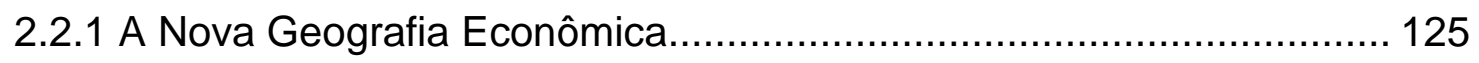

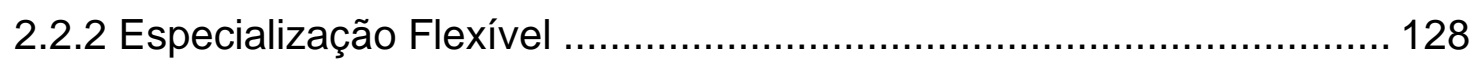

2.2.3 Estudos Urbanos: uma perspectiva da Economia ............................. 131

2.2.4 Os estudos das grandes cidades mundiais ..................................... 134

2.3 Do capitalismo neoliberal à metropolização: da centralidade cindida..... 151

2.3.1 Valorização, capitalização e megarregiões ....................................... 151

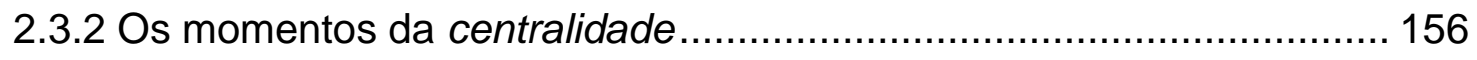

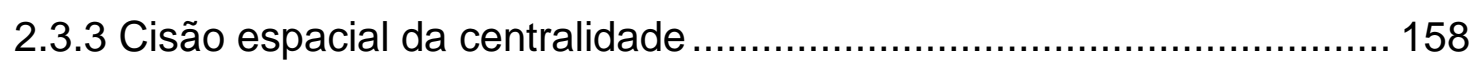

2.3.4 Centralização de capital e produção do espaço: a importância da renda da terra 159 
2.3.5 A formação, realização e distribuição da mais-valia e os circuitos de acumulação

2.3.6 A renda da terra 168

2.3.7 O papel da renda da terra e o circuito ampliado de circulação do capital. 172

2.3.8 Metropolização 177

2.3.9 Metropolização do espaço 186

2.4 O Baixo Tapajós no início do século XXI. 190

2.4.1 A infraestrutura das cadeias de valor globais ........ 200

2.4.2 A constituição do Arco Norte 201

2.4.3 A presença dos Grupos Econômicos. 214

Considerações finais.. 236

Referências 


\section{Introdução}

Esta tese tem por objetivo propor e defender uma abordagem baseada na Teoria Marxista do Valor para a compreensão da noção de centralidade urbana na sociedade contemporânea.

No entanto, à primeira vista, poderá parecer que segue outro caminho, ao invés de ir diretamente ao assunto, uma vez que vai discutir um conjunto grande de teorias, sobretudo no âmbito da Ciência Econômica, que ou se dedicou a compreender a noção de centralidade ou nela se baseou para propor esquemas explicativos à realidade urbana de suas épocas.

Da mesma forma, poderá parecer estranho numa discussão acerca das características contemporâneas definidoras dessa centralidade urbana 0 recurso ao estudo empírico de uma região que pode ser muita coisa, menos ser considerada central na estruturação de sua rede urbana de inserção, como é o caso de Itaituba no baixo Tapajós.

A provocação desse estranhamento é, contudo, parte da estratégia argumentativa aqui adotada, que busca lançar luz a um fenômeno a partir do contraste com seu contrário, com seu oposto, com sua alternativa, para que, com isso, aquilo que definitivamente os une seja exposto e elucidado.

De acordo com essa estratégia, separamos a tese em duas Partes com três movimentos, com os quais contrastaremos: no primeiro movimento, a compreensão de dois momentos históricos distintos. Na Parte 1, a compreensão da passagem do mundo liberal para o mundo fordistakeynesiano; e, na Parte 2, a superação deste último pelo mundo neoliberal. Com esse contraste poderemos identificar continuidades e rupturas entre esses diferentes momentos, explicitando o que eles têm em comum e no que diferem radicalmente.

Em um segundo movimento, contrastaremos as teorias (sobretudo econômicas) que buscaram explicar o desenvolvimento regional e urbano em cada um desses períodos históricos. Na primeira Parte daremos especial atenção à Teoria de Localização Industrial, à Teoria de Lugar Central e às Teorias de Polarização Regional. Na Parte 2, vamos discutir a abordagem da 
Nova Geografia Econômica, da especialização flexível e das abordagens da Escola Francesa de Metropolização. Com esse contraste poderemos identificar três momentos distintos do processo de urbanização, quais sejam, a urbanização liberal, a urbanização fordista e a metropolização neoliberal. Do ponto de vista dos fenômenos urbanos associados a esses momentos distintos, discutiremos a especificidade da noção de metrópole, a historicidade das abordagens das Cidades Globais e das Cidades-região, para chegarmos à compreensão das atuais Megarregiões como fenômeno urbano específico dessa racionalidade metropolitano-neoliberal.

Como veremos, a própria passagem do uso do termo urbanização para o termo metropolização carrega consigo uma proposta de periodização bastante clara, que se apoia, sobretudo, no contraste explicitado pelo primeiro movimento, o de contextualização histórica.

É nesse segundo movimento, em que se articulam de modo mais explícito pontes de diálogo entre economia e geografia e onde se recorre à Teoria do Valor, que se vai propor uma especificidade da centralidade metropolitano-neoliberal em relação às noções de centralidade típicas do mundo urbano-industrial, sejam elas liberais ou fordista-keynesianas. É nesse segundo movimento também que se vai propor que essa racionalidade metropolitano-neoliberal se opera por meio do processo de metropolização do espaço.

Na sequência, após explicitar os movimentos históricos e teóricos, será a vez do terceiro movimento, focado no desenvolvimento de abordagens empíricas nas quais as categorias trabalhadas em cada uma das Partes da tese serão articuladas com base em estudos existentes na Parte 1 e com produção de dados originais na Parte 2.

É do contraste entre as realidades de Itaituba entre os momentos do final do século XX e do início do século XXI que iremos indicar a especificidade do desenvolvimento urbano contemporâneo. Nesse movimento, vamos argumentar como que as categorias mobilizadas para sustentar as especificidades do momento histórico e dos processos de urbanização contemporâneos têm grande poder explicativo ao serem capazes de mostrar duas dinâmicas bastante distintas entre esses dois períodos. 
Com essa sequência de movimentos, pretendemos dar nossa contribuição ao esforço, que já vem sendo feito nas últimas décadas por diversos autores, de elucidar o próprio processo de metropolização do espaço.

Dada a escolha da estratégia acima descrita, gostaríamos de aqui salientar que, na realidade, essa estrutura reflete exatamente a própria trajetória intelectual do autor que, como visto na apresentação, vem se aproximando da temática aqui exposta de modo paulatino, desde a elaboração da sua dissertação de mestrado. Desse modo, além de uma estratégia argumentativa, a maneira com que esta tese está sendo defendida se baseia e se estrutura no próprio caminho percorrido pelo autor. Caminho esse que, com os resultados aos quais chegamos, entendemos ter sido - apesar de tortuoso capaz de contribuir para o debate no qual se insere. 


\section{Parte 1 - A urbanização fordista}

\section{Introdução}

Esta Parte 1 tem dois objetivos. Primeiro, contextualizar, teórica e historicamente, o surgimento das grandes metrópoles mundiais como fenômenos de um processo chamado de urbanização fordista.

Para tanto, serão consagrados dois itens. O Item 1.1, que discorrerá sobre a superação da sociedade liberal do século XIX e a consolidação do chamado modo de regulação fordista no século $\mathrm{XX}$, busca compreender os impasses enfrentados pelo liberalismo na virada do século passado e as disputas doutrinárias que coroaram o keynesianismo como arcabouço teórico dominante no pós- Segunda Guerra Mundial.

O Item 1.2 discorrerá sobre a maneira como, nesse modo de regulação fordista, em contraponto com a sociedade liberal, a Ciência Econômica buscou explicar a formação das redes de cidades, suas hierarquias e os processos cumulativos de causação circular que levaram à formação das grandes metrópoles mundiais. Nesse caminho, buscaremos elucidar as características definidoras de uma centralidade fordista, motor desse processo de urbanização fordista.

O segundo objetivo é o de contextualizar, teórica e empiricamente, o surgimento e/ou consolidação de redes de cidades hierarquizadas também como fenômeno desse processo de urbanização fordista. Para tanto, o Item 1.3 vai demonstrar que a urbanização observada na região do baixo Tapajós-PA é amplamente estudada e explicada por abordagens que adotam esse arcabouço teórico ou que se inspiram nele.

Com isso, pretende-se demonstrar que o processo de urbanização fordista explica tanto a formação das grandes metrópoles mundiais quanto a constituição de redes de cidades hierarquizadas a partir de princípios keynesiano-fordistas. 
À guisa de conclusão, discutiremos a pertinência de utilização dessas abordagens face às transformações do capitalismo contemporâneo que assume sua forma neoliberal, como será visto na Parte 2.

\subsection{A crise Liberal e o novo mundo Keynesiano}

De acordo com a perspectiva adotada, a de que vivenciamos, a partir do final do século $X X$, uma ruptura no modelo de urbanização, impôs-se a necessidade de compreendermos como se formou o modelo então superado e quais suas origens e características principais para, enfim, procedermos à compreensão desse novo e atual padrão, na segunda parte desta tese.

Para tanto, aqui, neste item, vamos ocupar-nos da compreensão da crise do capitalismo liberal e sua superação pelo capitalismo fordista, de base keynesiana, caracterizado pelo estado de bem-estar social, que teve sua hegemonia em boa parte do século XX e moldou o mundo como o vivenciamos na última virada de século.

Em 1944, no contexto da Segunda Guerra mundial, Karl Polanyi, em seu clássico $A$ Grande Transformação, declara, nas primeiras linhas, que "A civilização do século XIX ruiu." (POLANYI, K., 2000, p. 17). Para o autor, a civilização a que se refere se baseava em quatro pilares, dois de cada tipo. Pelo lado econômico, o padrão internacional do ouro e o mercado auto regulável; pelo lado político, o estado liberal e um sistema de equilíbrio de poder, que, argumentava, seriam responsáveis por impedir a ocorrência de guerras entre as grandes potências mundiais durante todo o século XIX. No entanto, como veremos, a aludida paz reinante durante cem anos ruiria justamente com a eclosão das duas grandes guerras mundiais e suas consequências em termos dos questionamentos acerca das causas que nos levaram a elas.

Reconhecendo o padrão-ouro como um dos principais pilares desse período, cuja superação "revelou-se a causa mais aproximada da catástrofe" (p. 17), Polanyi indica o mercado auto-regulável como matriz do sistema vigente durante o século XIX, que teria originado um tipo de civilização específica onde 
Uma economia de mercado significa um sistema auto regulável de mercados, em termos ligeiramente mais técnicos, é uma economia dirigida pelos preços do mercado e nada além dos preços do mercado. Um tal sistema, capaz de organizar a totalidade da vida econômica sem qualquer ajuda ou interferência externa, certamente mereceria ser chamado auto regulável. (POLANYI, K., 2000, p. 62)

O mercado auto-regulável, como locus de realização do "Homem Econômico" de Adam Smith, fundamentava uma sociedade liberal baseada na "propensão a intercambiar, permutar ou trocar uma coisa pela outra" (SMITH, 1996, p. 73), cujo único pressuposto é a liberdade absoluta que devem ter os homens de buscarem seus interesses próprios, uma vez que são os melhor posicionados e bem informados para a tomada de decisões que maximizem seus interesses individuais. Uma vez garantida a busca pelos interesses individuais, as leis de mercado fariam que, automaticamente, se chegasse aos melhores resultados do ponto de vista social. Caberia ao Estado única e exclusivamente deixar operar a "Mão invisível" do mercado para que o bemestar social estivesse garantido.

Do ponto de vista da modelagem econômica, para que se opere o equilíbrio de mercado e o encontro entre oferta e demanda a um determinado preço e quantidade, essa perspectiva leva aos postulados de concorrência perfeita, de equilíbrio entre os diferentes agentes econômicos que possuem comportamento maximizador de utilidade a partir de decisões baseadas em informações perfeitamente distribuídas. Ou seja, um conjunto de pressupostos que se mostraram, depois, difíceis de ser sustentados.

Durante boa parte do século XIX, o desenvolvimento industrial encontrou campo fértil de desenvolvimento, gerando, de fato, a incorporação, via força de trabalho, de parte significativa da população expulsa do campo, ocasionando, com isso, o extenso período de relativa tranquilidade a que Polanyi se referiu. No entanto, o aprofundamento das desigualdades advindas do "disfuncionamento" da chamada economia de mercado que, ao não funcionar segundo os princípios liberais, acabou sendo geradora de desigualdades tanto individuais quanto empresariais, acarretando, também, a configuração de economias oligopolistas (com desequilíbrios de poder entre os agentes, portanto), levaria o mundo liberal a se defrontar com seu esgotamento e com 
as consequências sociais e políticas advindas dessas crescentes desigualdades.

Nesse contexto, observa-se que o desenvolvimento industrial de países então periféricos, como a Alemanha e os Estados Unidos, aconteceu aceleradamente e sobre novas bases. Como resultado:

Sur le plan international la fin du XIXème siècle rassemblait guère à cette grande société universelle et pacifique organisée selon les principes rationnels de la division du travail qu'imaginait Ricardo [...] L'Allemagne comme l'Amérique offraient également le visage d'un capitalisme de grandes unités protégées par des barrières douanières élevées, tandis que l'Angleterre voyait ses propres positions industrielles remises en cause. ${ }^{1}$ (DARDOT; LAVAL, 2010b, p. 126)

A superação de uma estrutura de mercado de pequenas empresas por outra, com a dominação de grandes grupos econômicos, também produziu distorções no mundo político, que passou a ser cada vez mais capturado por interesses privados, configurando não mais uma economia liberal - na qual o Estado teria o papel de garantir as regras de concorrência e a liberdade dos agentes econômicos - e sim uma economia oligopolista, em que esses grandes grupos garantiam a prevalência de seus interesses frente aos de seus concorrentes, fortalecendo ainda mais seu poderio econômico e político.

Les politiciens faisaient surtout figure de marionnettes dans les mains de ceux qui détenaient le pouvoir de l'argent. ${ }^{2}$ (DARDOT; LAVAL, 2010b, p. 125)

Com capacidade de influência de agenda política, esses grandes grupos oligopolistas, que buscaram, durante um longo período, consolidar suas posições nacionalmente, passaram a disputar espaço, mercados e matérias primas internacionalmente, impondo uma escalada de protecionismo em nível internacional que reforçou suas posições oligopolistas, talvez monopolistas.

1 - No plano internacional o fim do século XIX se assemelhava bastante a eessa grande sociedade universal e pacífica organizada segundo os princípios racionais da divisão do trabalho que Ricardo imaginava[...] A Alemanha como a América ofereciam igualmente o rosto de um capitalismo sobre grandes unidades protegidas por barreiras alfandegárias elevadas, enquanto que a Inglaterra via suas próprias postições industriais ser postas em causa.

2 - Os políticos faziam sobretudo figura de marionetes nas mãos dos que detinham o poder do dinheiro. 
As tarifas de importação de um país dificultavam as exportações de outro e forçavam-no a procurar mercados em regiões politicamente desprotegidas. $O$ imperialismo econômico era principalmente uma luta entre potências pelo privilégio de estender seu comércio aos mercados politicamente desprotegidos. (POLANYI, K., 2000, p. 255)

Simultaneamente a esse movimento, o padrão-ouro, outro pilar da sociedade liberal, resultante da imposição hegemônica da dominação econômica inglesa, a economia mais forte em meados do século XIX, buscava minimizar o poder dos governos nacionais que se contrapunham ao predomínio do comércio de mercadorias inglesas no cenário internacional. Com o padrãoouro as economias nacionais não tinham efetivamente uma política monetária ao seu dispor, dado que a quantidade de moeda circulante (e, portanto, seu valor, sua taxa de câmbio) deveria preservar uma paridade constante para com a quantidade de ouro que cada país possuía. Dessa forma, desequilíbrios comerciais, que implicariam repasse de quantidades de ouro para compensar o comércio, sempre deficitário frente à Inglaterra, não poderiam ser compensados por desvalorização cambial. Como observa Polanyi,

O comércio internacional significava agora a organização da vida no planeta sob um mercado auto regulável, que compreendia o trabalho, a terra e o dinheiro, sendo o padrãoouro o guardião desse gigantesco autômato. Nações e povos eram apenas bonecos num espetáculo inteiramente fora do seu controle. (POLANYI, K., 2000, p. 254)

Como vetor de transposição, para além das fronteiras nacionais, das contradições e impasses inerentes à economia de mercado que se observava nas economias domésticas, o padrão-ouro levou para o âmbito internacional as mesmas limitações e impasses que o capitalismo liberal impunha domesticamente.

O padrão-ouro foi apenas uma tentativa de ampliar o sistema doméstico de mercado no campo internacional; o sistema de equilíbrio de poder foi uma superestrutura erigida sobre $O$ padrão-ouro e parcialmente nele fundamentada.(POLANYI, K., 2000, p. 17)

Desta forma, enquanto garantidor do funcionamento em escala internacional de uma economia de mercado, o padrão-ouro levava consigo as tensões e as disputas entre grupos econômicos nacionais oligopolizados, 
ampliando os efeitos deletérios da economia de mercado em níveis internacionais e à disputa entre grandes interesses oligopolistas. Quando ele se desintegra, leva consigo todos os pressupostos da sociedade liberal, sobretudo o próprio livre mercado.

O colapso do padrão-ouro internacional foi o elo invisível entre a desintegração da economia mundial na virada do século e a transformação de toda uma civilização na década de 1930. (POLANYI, K., 2000, p. 36)

A velocidade com que o padrão-ouro ruiu resultou em intenso choque, que atingiu o equilíbrio existente entre as nações, acelerando tensões que levariam ao fim do desenvolvimento da industrialização em sua fase liberal, base daqueles cem anos de relativa paz e prosperidade mundial.

Não se percebeu a verdadeira natureza do sistema internacional sob o qual vivíamos senão quando ele entrou em colapso. Quase ninguém compreendeu a função política do sistema monetário internacional, e a terrível rapidez da transformação tomou o mundo completamente de surpresa. E, no entanto, o padrão-ouro era o único pilar remanescente da economia mundial tradicional; quando ele ruiu, o resultado teria que ser imediato. (POLANYI, K., 2000, p. 36)

Em resumo, é neste momento que o liberalismo enfrenta o nível máximo de questionamento quanto a seus pressupostos e sua hegemonia. No entanto, tais questionamentos já vinham de longa data e a velocidade e a força com que os efeitos deletérios do liberalismo se apresentaram puseram a própria democracia liberal em questão.

La Première Guerre mondiale et les crises qui I'ont suivi n'ont fait qu'accélérer une remise en cause générale de dogmes libéraux du XIXème siècle. Que faire des vieilles images idéalisées de l'échange libre quand c'est tout l'équilibre social et économique qui paraît ébranlé ? Les crises économiques à répétition, les phénomènes spéculatifs, les désordres sociaux et politiques montraient toute la fragilité des démocraties libérales. ${ }^{3}$ (DARDOT; LAVAL, 2010b, p. 142)

3 - A Primeira Guerra mundial e as crises que the seguiram não fizeram senão acelerar um questionamento geral dos dogmas liberais do século XIX. Que fazer das velhas imagens idealizadas da livre troca quando é todo o equilíbrio social e econômico que parece abalado? As crises econômicas repetidas, os fenômenos especulativos, as desordens sociais e políticas evidenciavam a fragilidade das democracias liberais. 
Nesse contexto, Polanyi constata que, após a Primeira Guerra Mundial e o colapso do mundo liberal, houve uma grande transformação, que se operou de forma radical, marcando o fim do predomínio do mercado sobre a sociedade.

Uma transformação social de alcance planetário é coroada por guerras de um tipo sem precedente, nas quais uma série de estados entra em colapso e os contornos de novos impérios se delineiam num mar de sangue. (POLANYI, K., 2000, p. 18)

O colapso dos Estados e consequente mar de sangue se configuraram à época como alternativas em termos de organização da sociedade, agora não mais sob a égide do mercado, ou seja, não mais sob a égide da liberdade individual acima dos interesses sociais. Como é sabido, a transformação à qual Polanyi faz referência é a superação da sociedade e da democracia liberais operada a partir da ascensão do fascismo e do socialismo. Ambas as alternativas apareceram, em seu tempo, como uma forma de a sociedade retomar o controle sobre o indivíduo, deixando de lado as liberdades individuais e a economia de mercado como princípio ordenador da sociedade.

A solução fascista do impasse atingido pelo capitalismo liberal pode ser descrita como uma reforma da economia de mercado, alcançada ao preço da extinção de todas as instituições democráticas, tanto no campo industrial como no político. (POLANYI, K., 2000, p. 276)

E, na visão de Polanyi, à época,

O socialismo é, na sua essência, a tendência inerente a uma civilização industrial de transcender o mercado auto-regulável, subordinando-o, conscientemente, a uma sociedade democrática. (POLANYI, K., 2000, p. 273)

Vale lembrar que Polanyi testemunhou a ascensão do fascismo e do socialismo, tendo analisado como cada um deles propõe uma alternativa à sociedade liberal.

A civilização do século XIX não foi destruída por ataques de bárbaros externos ou internos; sua vitalidade não foi solapada pelas devastações da Primeira Guerra Mundial, nem pela revolta de um proletariado socialista ou de uma classe média baixa fascista. Seu fracasso não foi consequência de alguma suposta lei de economia, como a taxa de lucros decrescentes, 
a do subconsumo ou a da superprodução. Ela se desintegrou como resultado de um conjunto de causas inteiramente diferentes: as medidas que a sociedade adotou para não ser aniquilada, por sua vez, pela ação do mercado auto- regulável. (POLANYI, K., 2000, p. 289)

Como síntese, Polanyi apenas nos lembra que a civilização do século XIX se exauriu a partir do seu interior ou de seus próprios fundamentos que, segundo ele, estariam sendo superados. Não teria sido possível ao autor, contudo, antever a resposta que o próprio pensamento liberal daria a esse impasse, ressignificando alguns de seus pressupostos em duas correntes principais, como veremos a seguir.

A reconfiguração do pensamento liberal permitiu, na realidade, o fortalecimento das economias de mercado, mesmo que, por um certo momento, estas tenham passado por uma etapa em que chegou a ser tachada por muitos liberais de tendência socialista, apesar de não sê-lo. Essa etapa, conhecida como o estado de bem estar social de inspiração keynesiana, também poderia ser considerada uma expansão da sociedade sobre 0 indivíduo, apesar de isso não ter sido objeto da análise de Polanyi para quem, de fato, a economia de mercado estaria sendo superada, desintegrada.

A derrocada da sociedade industrial liberal levou com ela as lógicas de estruturação dos espaços regionais e dos processos de urbanização como vivenciados até aquele momento. Como veremos, no âmbito da Economia, esse período histórico da sociedade liberal encontra nas Teorias de Localização clássicas um aparato teórico capaz de explicar seus principais traços. Veremos também que, com a superação da sociedade liberal, essa lógica urbano-liberal será suplantada por outra, a urbano-fordista e novas teorias serão mobilizadas para pensar a configuração dos espaços regionais e processos de urbanização. Contudo, o que ambas lógicas têm em comum é o fato de serem profundamente ancoradas no desenvolvimento industrial e suas mutações. Permanecem, portanto, na mesma lógica de acumulação capitalista, apesar de se relacionarem a fenômenos regionais e urbanos distintos. Por enquanto, pretendemos focar a atenção no que efetivamente se constituiu como alternativa ao liberalismo. 
Do ponto de vista doutrinário, Dardot e Laval (2010b), em seu capítulo intitulado "Crise du liberalisme et naissance du néolibérlisme", reconstituem as disputas internas ao próprio liberalismo que operaram a possibilidade de sua superação. Baseado no direito natural, na liberdade do comércio, na propriedade privada, nas virtudes do equilíbrio de mercado, esse momento do capitalismo industrial chega ao século XX com seus dogmas fraturados a ponto de os autores entenderem que, na virada do século, "La crise du libéralisme est aussi une crise interne"4 (2010b, p. 122).

Dès le milieu du XIXème siècle, le libéralisme expose des lignes de fracture qui iront en s'approfondissant jusqu'à la Première Guerre mondiale et l'entre-deux-guerres. Les tensions entre deux types de libéralisme, entre celui des réformateurs sociaux qui défendent un idéal de bien commun et celui des partisans de la liberté individuelle comme fin absolue, n'ont en réalité jamais cessé. ${ }^{5}$ (DARDOT; LAVAL, 2010b, p. 122-123)

Segundo a leitura dos autores, o campo hegemônico encontrava-se em disputa justamente no momento em que o próprio liberalismo mostrava seus limites enquanto regime de acumulação, dada a "necessité pratique de I'intervention gouvernementale pour faire face aux mutations organisationnelles du capitalisme [...]qui mettent 'en crise' le libéralisme dogmatique." ${ }^{\prime 6}$ (2010b, p. 123).

Para além das respostas de cunho totalitário apontadas por Polanyi, internamente, alternativas ao liberalismo foram elaboradas, de modo a buscar viabilizar uma nova forma de liberalismo, respeitando seus princípios fundadores. A partir desse exercício, vemos consolidar-se o já exaustivamente conhecido neoliberalismo, mas, também, o novo liberalismo, menos conhecido. Ambos se colocam, desde o início, como tentativas de evitar a virada totalitária.

[...] il s'agissait dans les deux cas de répondre à une crise du mode de gouvernement libéral, de surmonter les difficultés de toutes sortes nées des mutations du capitalisme des conflits

4 - "a crise do liberalismo é também uma crise interna"

5 - "Desde a metade do século XIX, o liberalismo expõe linhas de fratura que irão aprofundand(o-se até à Primeira Guerra mundial e o entre as duas guerras As tensões entre dois tipos de liberalismo, entre o dos reformadores sociais que defendem um ideal de bem comum e o dos partidários da liberadade individual como fim absoluto na realidade nunca cessaram."

6 - "necessidade prática da intervenção governamental para enfrentar as mutações organizacionais do capitalismo, nos conflitos de classe ameaçando a 'propriedade privada', nas novas relações de força internacionais, que punham 'em crise' o liberalismo dogmático." 
sociaux, des affrontements internationaux. II s'agissait même, plus fondamentalement, de faire face à ce qui a pu apparaître un moment comme la 'fin du capitalisme', laquelle fin c'est incarnée dans l'ascension des 'totalitarismes' après la Première Guerre mondiale. ${ }^{7}$ (DARDOT; LAVAL, 2010b, p. 152)

Essas duas alternativas compartilhavam, desde suas origens, uma preocupação de fornecer elementos que justificassem e estruturassem o fortalecimento do papel do Estado frente aos efeitos nocivos decorrentes das liberdades individuais que caracterizaram o Estado liberal e forjaram a economia de mercado. Mesmo que se diferenciando na racionalidade adjacente a essa atuação, buscavam, com isso, preservar esses pilares do capitalismo liberal. Contudo, não devemos perder de vista essa origem comum, justamente no momento em que a sociedade liberal entra em colapso.

Ce que ces deux courants se sont progressivement découvert en commun, pour le dire brutalement, c'est un ennemi commun, le totalitarisme, c'est-à-dire la destruction de la société libérale. C'est sans doute ce qui les a poussées à forger un discours à la fois théoriques et politiques qui donne raison, forme, sens à l'intervention gouvernementale, un discours nouveau qui produise une nouvelle rationalité gouvernementale. ${ }^{8}$ (DARDOT; LAVAL, 2010b, p. 152)

Como expoente maior do novo liberalismo, os autores reconhecem em Keynes, contrariamente às leituras mais correntes, os traços desse novo discurso de renovação do liberalismo, indicando que, na realidade, toda alteração das funções do Estado propostas pelo keynesianismo (o chamado Estado Keynesiano) passa pela tentativa de garantir uma sociedade de liberdades individuais, com a condição de que essas liberdades individuais favoreçam a todos e não sejam apenas meios para a busca de maximização individual de interesses. (DARDOT; LAVAL, 2010b, p. 153)

7 - [...] tratava-se nos dois casos de responder a uma crise do modo de governo liberal, de ultrapassar as dificuldades de toda espécie nascidas de mutações do capitalismo, de conflitos sociais, de enfrentamentos internacionais. Tratava-se mesmo, mais fundamentalmente, de enfrentar o que pôde aparecer um momento como «o fim do capitalismo", o qual se encarnou na ascensão dos 'totalitarismos' depois da Primeira Guerra mundial.

8 -'O que essas duas correntes progressivamente descobriram em comum, para dizê-lo brutalmente, foi um inimigo comum, o totalitarismo, isto é, a destruição da sociedade liberal. Foi sem dúvida isso que os levou a forjar um discurso simultaneamente teórico e político que dá razão, forma, sentido à intervenção governamental, um discurso novo que produz uma nova racionalidade governamental. 
A compreensão do modo como o ideário de Keynes pode ser compreendido inserido numa continuidade da linhagem liberal se opera a partir da proposição de que a adoção de meios "aparentemente opostos aos princípios do liberalismo" é a melhor maneira de garantir a realização dos próprios ideais liberais:

[...] la réalisation des idéaux du libéralisme réclame que l'on sache utiliser des moyens apparemment étrangers où opposés aux principes libéraux pour mieux en défendre la mise en œuvre: lois de protection du travail, impôts progressifs sur le revenu, assurance sociale obligatoire, dépenses budgétaires actives, nationalisations. ${ }^{9}$ (2010b, p. 153)

Paradoxalmente, esta proposição incorpora uma parte significativa das críticas ao liberalismo advindas de teorizações e práticas de cunho socialista e se inspira nelas, configurando esse novo liberalismo sem, contudo, buscar a superação total dos dogmas do liberalismo.

Un « nouveau libéralisme » plus conscient des réalités sociales et économiques cherchait à définir depuis longtemps une nouvelle manière de comprendre les principes du libéralisme, qui emprunterait au socialisme certaines de ces critiques mais pour mieux réaliser les fins de la civilisation libérale. ${ }^{10}$ (2010b, p. 153)

A corrente dos chamados reformadores sociais, da qual Keynes faz parte, ganha terreno à medida que o próprio capitalismo, cuja potência não mais se encontrava na Inglaterra e havia deslocado seu centro de poder para os Estados Unidos e para a Alemanha, passa por mutações profundas e

démontrait que le modèle atomistique d'agents économiques indépendants, isolés, guidés par le souci de leur intérêt bien compris et dont les décisions était coordonnées par le marché concurrentiel, ne correspondait plus guère aux structures et aux

9 - [...] a realização dos ideais do liberalismo exige que se saiba utilizar os meios aparentemente estranhos ou opostos aos princípios liberais para melhor defender a colocação deles em prática : leis de proteção do trabalho, impostos progressivos sobre a renda, securidade social obrigatória, despesas orçamentárias ativas, nacionalizações.

10 - Um "novo liberalismo" mais consciente das realidades sociais e econômicas procurava definir depois de muito tempo uma nova maneira de compreender os princípios do liberalismo, que pediria emprestado ao socialismo algumas de suas críticas mas para melhor realizar os fins da civilização liberal. 
pratiques du système industriel et financier réellement existant. ${ }^{11}$ (DARDOT; LAVAL, 2010b, p. 124)

Havia, portanto, um claro diagnóstico de que, frente às novas formas de organização e práticas industriais, não mais atomizadas e concorrenciais, mas sim resultantes da formação de grandes oligopólios, seria necessária a atuação frente às desigualdades que esses oligopólios impunham ao sistema como um todo. Segundo os autores,

Ce que le libéralisme classique n'avait pas suffisamment intégré, c'était précisément le fait même de l'entreprise, de son organisation [...] de la concentration de ses moyens, des nouvelles formes de compétition [...] L'entreprise moderne [...] était devenue une réalité que la science économique dominante ne parvenait pas encore à comprendre ${ }^{12}$.(DARDOT; LAVAL, 2010b, p. 125).

A vantagem da análise retroativa é a de nos permitir conceber 0 passado a partir da experiência vivida. Além disso, o capitalismo tem demonstrado perseverança e enorme capacidade de se reinventar, superando suas crises e impasses. Essa compreensão de que tanto o keynesianismo como um novo liberalismo - quanto o neoliberalismo são formas de buscar preservar os princípios do capitalismo liberal, adequando-o às realidades econômicas e sociais de suas épocas, permite aos autores indicar que a "grande transformação" à qual Polanyi faz referência, como sendo "la fin de la civilisation du XIXème siècle, la mort du libéralisme économique et de son utopie"13 não estaria assim tão correta, já que Polanyi teria feito um "erro de diagnóstico", justamente porque o liberalismo estaria se reinventando, e não morrendo ou sendo superado (DARDOT; LAVAL, 2010b, p. 150).

John Maynard Keynes escreve seu livro mais influente exatamente entre as duas Grandes Guerras, após o crash de 1929 e mais de 10 anos antes da contribuição de Polanyi com seu A Grande Transformação. Como vimos, o

11 - Demonstrava que o modelo atomístico de agentes econômicos independentes, isolados, guiados pela preocupação do seu interesse bem compreendido e cujas decisões estavam coordenadas pelo mercado concorrente, não correspondia mais às estruturas e às práticas do sistema industrial e financeiro realmente existente

12 - "O que o liberalismo clássico não tinha suficientemente integrado era precisamente o fato mesmo da empresa, de sua organização... da concentração de seus meios, das novas formas de competição... A empresa moderna ...tinha-se tornado uma realidade que a ciência econômica dominante não tinha ainda chegado a compreender".

13 - o fim da civilização do século XIX, a morte do liberalismo econômico e de sua utopia 
teórico liberal entendia que caberia ao próprio mercado de trabalho encontrar soluções para o crescente desemprego e para a crise generalizada, resultante dos desequilíbrios entre oferta e demanda agregadas na economia. Partindo da compreensão das causas dos desequilíbrios existentes, Keynes propõe que é por meio do estímulo em investimento público e a geração de emprego que seria possível recuperar uma trajetória de crescimento econômico, a partir do efeito multiplicador e dinamizador da economia proveniente da expansão dos gastos públicos, reestabelecendo as virtudes da economia de mercado, agora de forma dirigida.

Por outro lado, em plena crise da Primeira Guerra Mundial, e no âmbito da organização industrial, Henry Ford, em 1914, estabelece novos parâmetros de jornada de trabalho e revoluciona o mundo industrial. Revolução essa que terá um impacto bastante grande em nossa sociedade. Como será desenvolvido adiante, o termo fordismo, em sua concepção mais ampla, engloba os conceitos de regime de acumulação e modo de regulação e incorpora o ideário keynesiano. No entanto, nesse primeiro momento, 0 "sistema de produção implantado por Ford cuidava desde a produção da matéria-prima inicial até o produto final, envolvendo inclusive a sua distribuição comercial por meios de agências próprias" (GUERRA, 2000, p. 72), cristalizando o domínio econômico de grandes empresas e oligopólios.

Essa primeira fase marcou a diferença entre o taylorismo ${ }^{14}$ e o fordismo quando este último estrutura uma nova lógica de produção, agora predominantemente uma produção em massa aliada ao consumo de massa, que configura um novo sistema de reprodução da força de trabalho. Inicia-se também uma nova política de controle e gerenciamento do trabalho reverberando "uma nova estética e uma nova psicologia, em suma, um novo tipo de sociedade democrática, racionalizada, modernista e populista". (HARVEY, 1994, p. 121)

Desse modo, é importante enfatizar que

14 - Como será destacado mais à frente, uma das principais características do Fordismo está na racionalização do trabalho e na mecanização da produção com tecnologia mais especializada. No início o taylorismo exigia certa qualificação da mão de obra ou alguma "cultura industrial". Entretanto, o que diferencia o taylorismo do fordismo é a produção em massa do segundo para atender à demanda crescente de um mercado consumidor impulsionado por políticas redistributivas. 
o fordismo é proposto como uma referência muito mais ampla do que a revolução tecnológica e organizacional realizada por Henry Ford em sua fábrica de automóveis. A combinação de produção e consumo em massa do regime de acumulação fordista envolveu não somente a difusão do método de produção de Henry Ford para vários setores e economias nacionais mas também, e principalmente, novos compromissos salariais e de classe, ampliação das ações estatais e reformulação das políticas econômicas, reformas nas relações econômicas internacionais e novos hábitos culturais. (ARIENTI, 2002, p. 6)

É no pós-Segunda Guerra Mundial que o pensamento keynesiano ganha expressão, embasado no papel do Estado como principal agente de estímulo ao crescimento econômico. O Estado - por meio de investimento no setor produtivo, e, portanto, na geração de emprego- se transformaria em patrocinador de grandes projetos, produtivos ou de infraestrutura, que viabilizariam a expansão da renda, da produtividade, das áreas de mercado e, sobretudo, do consumo e da produção em massa dos grandes oligopólios.

De certa forma, coube ao keynesianismo aprofundar a estrutura oligopolista da sociedade liberal do início do século $\mathrm{XX}$, fornecendo-lhe as condições da expansão da demanda via gasto público e por meio de garantias de expansão real do poder de compra via políticas distributivas. Desta forma, reforça-se a análise de que o keynesianismo se insere na linhagem que busca resguardar a integridade do ideário liberal, fornecendo as condições para que a sociedade de mercado, mesmo que com maior participação do Estado, possa se perenizar e não sucumbir aos riscos totalitários. Devemos nos lembrar disso mesmo

Si Keynes deviendra plus tard la cible favorite des néolibéraux, il ne faut pas oublier que keynesianisme et néolibéralisme ont partagé un temps les mêmes préoccupations : comment sauver contre le libéralisme lui-même ce qu'on peut du système capitaliste ? $^{15}$ (DARDOT; LAVAL, 2010b, p. 142)

Como resultante da hegemonia das políticas keynesianas de fortalecimento de grandes empresas, do patrocínio do desenvolvimento da

15 - Se Keynes se tornará mais tarde a presa favorita dos neoliberais, é preciso não esquecer que keynesianismo e neoliberalismo partilharam por um tempo as mesmas preocupações : como salvar contra o próprio liberalismo o que for possível do sistema capitalista? 
produção e do consumo de massa, passamos a vislumbrar a consolidação do chamado fordismo como regime de acumulação do capitalismo moderno, resultante da sobrevida de uma economia de mercado adaptada à realidade do século XX. Nesse momento, o regime de acumulação fordista estabelecia novas formas de "realocação sistemática do produto, que administra, ao longo de um período prolongado, uma certa adequação entre as transformações das condições da produção e aquelas das condições do consumo" (LIPIETZ, 1989, p. 304).

A abordagem regulacionista, desenvolvida inicialmente por Aglietta (1976), relaciona "variáveis técnicas e organizacionais da base produtiva e seus efeitos para o equilíbrio macroeconômico, como as variáveis sociais e as variáveis políticas, como as funções e as formas dos Estados nacionais capitalistas". Nessa articulação entre as esferas econômica, social e política se determinava a "formação de um conjunto de relações, processos, instituições e estruturas que garantam condições para a acumulação de capital". (ARIENTI, 2002, p. 5)

Como mostra Lipietz (1989), o regime de acumulação predominante em um determinado momento histórico está fortemente atrelado à sua lógica de expansão, à sua capacidade de "aumentar a escala de produção" (p. 305).

De forma esquemática, da primeira revolução industrial até a Primeira Guerra Mundial, prevaleceu, nos primeiros grandes países capitalistas, um regime de acumulação preponderantemente extensivo, centrado na reprodução ampliada dos bens de capital e, desde a Segunda Guerra, um regime preponderantemente intensivo, centrado no crescimento do consumo de massa. (p. 305).

A partir da leitura da escola da regulação, que propõe que "Um dado regime de acumulação não se satisfaz com qualquer modo de regulação ${ }^{16 " ~ e ́ ~}$ possível compreender a derrocada do mundo liberal como a "primeira crise da acumulação extensiva ou a última crise da 'regulação concorrencial'” (p. 306), e compreende-se a constituição, a partir da Segunda Grande Guerra, de um modo de "regulação monopolista", associado ao regime de acumulação

16 - Modo de regulação entendido como as "formas institucionais, procedimentos e hábitos - agindo como forças coercitivas ou indutoras - que conduzem os agentes privados a obedecer a tais esquemas [de reprodução do capital]" (Lipietz, 1989, p. 305) 
intensiva, que "incorporou, a priori, um crescimento do consumo popular proporcional aos ganhos de produtividade na determinação dos salários e dos lucros" (p. 306).

Segundo Abramo (1995, p. 513),

A partir dessa tipologia de formas de acumulação do capital, que pode ser identificada nos textos de Marx e que traduz, grosso modo, a predominância de uma das duas formas de extração da mais-valia (absoluta e relativa), os autores da regulação procuram estabelecer uma distinção conceituai e histórica na forma de organização do trabalho e na forma de estabelecimento do salário. Como esse modo de regulação monopolista, no imediato pós-Segunda Guerra Mundial, estava associado tanto às práticas de organização industrial da produção em massa quanto associado às políticas keynesianas que conduziam os agentes privados a obedecer aos esquemas gerais de reprodução do capital, garantindo ganhos salariais reais, acabou por receber o nome de "fordismo", e é a ele que nos referimos quando propomos compreender 0 desenvolvimento regional e urbano modernos.

O fordismo, portanto, que constitui a etapa intensiva, alia a produção e o consumo de massa a uma combinação de empresas com alta racionalização e grande participação do Estado. É com essa influência do keynesianismo na política econômica que se apresenta o modo de acumulação monopolista em que as empresas dividem os riscos das atividades econômicas diretamente com o Estado, por meio de regulamentações e com instrumentos macroeconômicos ${ }^{17}$.

Pela compreensão das características que diferenciam a sociedade liberal da sociedade fordista, ambas, contudo, industriais, mas baseadas em sistemas sociais, políticos e econômicos distintos, como procuramos demonstrar anteriormente, é que vamos buscar especificar as implicações que essas distinções fornecem para o entendimento dos processos de urbanização atrelados à industrialização nos séculos XXI e XX. Se podemos qualificá-los como momentos distintos do capitalismo, podemos trabalhar com a distinção entre um processo urbano-liberal e outro urbano-fordista, que será importante para compreendermos o que de fato estará sendo ultrapassado na passagem

17 - O Estado assumiu sua característica keynesiana, no lado da demanda, ao adotar políticas macroeconômicas expansionistas para garantir uma demanda efetiva sempre próxima ao pleno emprego. (ARIENTI, 2002, p. 12) 
para o século XXI, quando da superação do fordismo (e não necessariamente do mundo industrial).

\subsection{A estruturação do espaço regionail na virada do mundo liberal para uma sociedade fordista}

De forma esquemática, o arcabouço teórico, no âmbito das ciências econômicas, que se dedica ao estudo das regiões e cidades busca compreender o processo de urbanização como resultante de um jogo de forças entre diferentes cidades, entre diferentes locais ${ }^{18}$, que levam a processos de diferenciação regional.

Nesse contexto, as teorizações acerca dos processos regionais acompanharam as mudanças observadas na sociedade do século XX. Em um primeiro momento, marcado pela economia liberal do laissez-faire e pelos modelos econômicos de concorrência perfeita, situam-se as teorias que se baseiam nesses princípios. No entanto, como veremos adiante, num segundo momento, a partir da emergência do fordismo e, junto com ele, do keynesianismo, um novo conjunto de teorias buscou explicar as dinâmicas regionais e embasar a ação de planejamento territorial.

No que se refere ao primeiro momento, destacam-se os estudos constitutivos das chamadas teorias clássicas de localização, que vão de VON THÜNEN (1966), no começo do século XIX (1826), a Isard (1949), que serão explicitados mais adiante; enquanto o segundo momento define um "conjunto de teorias de desenvolvimento regional, com ênfase em fatores de aglomeração de inspiração marshalliana e keynesiana", (MONASTÉRIO; CAVALCANTE, 2011, p. 45) como, por exemplo, em Perroux (1955), Myrdal (1960), Hirschman (1961) e North (1955).

Como veremos a seguir, ambos os conjuntos teóricos foram muito relevantes para explicar o processo de urbanização de suas épocas. As teorias clássicas de localização se baseavam na racionalidade clássica da concorrência perfeita e do liberalismo econômico e, com isso, foram capazes

18 - O que Thisse (2011, p. 18) chamou de "trade-off entre diferentes tipos de economias de escala na produção e o custo de mobilidade de bens, pessoas e informação", algo que estaria no "centro da geografia econômica desde o trabalho dos primeiros teóricos locacionais, como Lösh (1954) e Hoover (1936)". 
de compreender a formação dos sistemas urbanos decorrentes do predomínio do capitalismo concorrencial. Já o segundo conjunto teórico conseguiu lidar melhor com as transformações estruturais operadas na passagem do capitalismo concorrencial para o capitalismo oligopolista, da grande concentração de capital, seja ela espacial ou patrimonial, indutor de maior integração e diferenciação entre as regiões. A passagem de um modelo para o outro foi bem descrita por Dardot e Laval (2010b):

Les capitalismes américain et allemand, les deux puissances émergentes de la seconde moitié du siècle [XIX], démontrait que le modèle atomistique d'agents économiques indépendantes, isolés, guides par le souci de leur intérêt bien compris et dont les décisions étaient coordonnées par le marché concurrentiel, ne correspondait plus guère aux structures et aux pratiques du système industriel et financier réellement existant. Ce dernier, de plus en plus concentre dans des branches majeurs de l'économie, dominé par une oligarchie en imbrication étroite avec les dirigeants politiques. ${ }^{19}$ (DARDOT; LAVAL, 2010b, p. 124)

Assim, discutiremos as teorias econômicas que buscam contextualizar esses dois momentos do capitalismo industrial, operando a passagem do mundo liberal para o mundo fordista, para que possamos demonstrar a importância de atualização do arcabouço teórico de análise quando se operam transformações estruturais na sociedade.

No que se refere às teorias clássicas de localização, observamos que seus principais autores buscam lidar, sob diferentes perspectivas, com o tradeoff entre os ganhos de economias de escala e as variações nos custos de mobilidade de bens, pessoas e informações entre localidades distintas. É também no contexto do desenvolvimento dessa literatura que o conceito de economia de aglomeração, fundamental para a compreensão dos processos de formação das cidades, é estabelecido.

19 O capitalismo americano e o alemão, as duas potências emergentes da segunda metade do sécul0 [XIX], demonstravam que o modelo atomístico de agentes econômicos independentes, isolados, guiados pela preocupação de seu interesse bem compreendido e do qual as decisões eram coordenadas pelo mercado concorrencial não correspondia mais às estruturas e às práticas do sistema industrial financeiro realmente existente. Este último, mais e mais concentrado nos ramos maiores da economia, dominado por uma oligarquia em imbricação estreita com os dirigentes políticos. 
De forma sintética, é importante reter que esse conceito é amplamente utilizado por várias correntes de pensamento na economia regional e urbana, tanto de tradição neoclássica, quanto de diferentes tradições heterodoxas. Em várias correntes econômicas, é um dos conceitos que, ao explicitarem os efeitos aglomerativos da concentração de atividades econômicas e mercado consumidor em uma localidade, justificam economicamente a existência de cidades e suas hierarquias.

Como salienta Catin (1994), a origem do conceito, no entanto, não pode ser unicamente atribuída ao trabalho primordial de Marshall (1983). Neste, encontramos a consolidação do conceito de economias externas como forma de compatibilizar, no plano teórico, a existência efetiva de retornos crescentes ao nível da indústria e a necessidade de retornos constantes ao nível da firma ${ }^{20}$ para a possibilidade de existência de um equilíbrio único de mercado em concorrência perfeita.

De acordo com Marshall, em seus Princípios de Economia, de 1890, a atividade industrial pode, sob determinadas condições, apresentar tanto economias de escala interiores à firma, o que chama de economia de escala microeconômica, quanto economias de escala externas às firmas, ou, em seus termos, economias macroeconômicas. As primeiras levariam à concentração de capital, formação de oligopólios e diferenciação de forças entre as firmas em suma, a uma economia desigual na relação de forças entre agentes econômicos. As segundas, por sua vez, levariam à concentração da atividade econômica em regiões específicas, em detrimento de outras que, por diversos motivos, começaram a atividade industrial com atraso.

A segunda fonte de inspiração para a constituição do conceito de economia de aglomeração pode ser encontrada em Weber (1929), quando discute a localização industrial, na qual as economias referentes à localização de mão de obra mais barata e as economias provenientes de um determinado processo aglomerativo devem ser levadas em consideração para a determinação da localização ótima de uma firma.

20 - Aqui adotamos a utilização dos temos indústria e firma advindos da microeconomia, que postula a firma como unidade decisória da economia de mercado e indústria como o agregado de firmas setorialmente próximas. 
No entanto, é apenas com o trabalho de Hoover (1936), de ênfase eminentemente empírica, e, fundamentalmente, com as formalizações teóricas de Isard (1949), que a economia espacial ganha corpo teórico e o conceito de economias de aglomeração, densidade. Para Isard, as economias de aglomeração são definidas, em alusão direta a Marshall, como economias de escala externas à firma, que podem se apresentar como internas a uma indústria (setor) em uma certa região - e recebem o nome de economias de localização - ou, além de externas à firma, também externas à indústria, atuando no conjunto das atividades de uma determinada região - e recebem o nome de economias de urbanização.

A discussão acerca do papel das economias de aglomeração para o processo de urbanização é bastante importante no desenvolvimento das teorias de localização, em especial para a Teoria de Lugares Centrais desenvolvida por Christaller (1966) na década de 1930, que se apresenta como uma teoria geral, uma vez que explica não apenas o crescimento dentro de uma cidade individualizada, mas também a distribuição espacial dos centros urbanos na economia regional e nacional. (CLEMENTE; HIGACHI, 2000, p. 88).

Assim, a Teoria de Lugares Centrais contribui de forma decisiva para a questão da compreensão do processo de ordenamento espacial entre as cidades, pois trata do conceito de lugar, tão importante na ótica da hierarquização de centros, dada a funcionalidade destes e a disponibilidade de maior dotação de bens e serviços. De forma geral, quanto maior a especialização ou grau de sofisticação dos tipos de serviços encontrados em uma cidade, maior a centralidade do lugar em questão - isto é, a ordem (dentro de uma hierarquia) dos bens e serviços oferecidos num centro está associada à própria ordem de importância (ou centralidade) dele.

Logo, Christaller (1966) define "lugar central de primeira ordem" central places of a higher order - determinando um sistema de cidades em que sua localização - ou posição de cada uma delas - depende diretamente da quantidade e diversidade de bens centrais e de serviços fornecidos. Esse sistema estabelece elos entre as cidades com diferentes níveis de centralidade, determinando assim uma área de influência, isto é, uma área ao redor de cada 
lugar ou espaço que está sob o controle desse lugar central de primeira ordem em suas diversas esferas - seja econômico, político e/ou social. Ao se fundamentar na hierarquização dos serviços, acaba também por hierarquizar os lugares, de acordo com suas centralidades.

Christaller (1966) designa dois termos capazes de descrever a distribuição e o tamanho das cidades: distância e limite, visto que sua teoria parte das funções (serviços e bens ofertados) orientadas pelo mercado e para ele. Nesse sentido, as variações de funções da cidade dependem de economias de escala e custo de transporte associados à oferta desses bens e serviços (trade-off). A distância determina a amplitude máxima que as pessoas estarão dispostas a viajar para obter um bem ou serviço, enquanto o limite é a quantidade mínima de pessoas (escala) necessária para instalar ou manter uma atividade econômica.

Segundo o autor, esses dois fatores criam uma hierarquia no espaço e, no contexto de economia concorrencial do século XIX, têm um poder descritivo bastante eficaz em explicar o padrão relativamente homogêneo de distribuição espacial observado na Alemanha no início do século XX.

Antes de Christaller, e contemporâneo de David Ricardo, Von Thünen (1966) já havia teorizado acerca do uso do solo, no caso agrícola, mas sem relações com outros centros, ao descrever os padrões de ocupação do espaço em torno das cidades da Alemanha pré-industrial. Os pressupostos clássicos para sustentar seu modelo são os de que: i) os agentes econômicos são tomadores de preço; ii) existência de livre entrada nas atividades agrícolas, portanto, sem lucros extraordinários; iii) ocorrência de retornos constantes de escala e coeficientes fixos de produção; iv) terreno homogêneo (a questão principal para o autor não é a fertilidade do solo, como para Ricardo); e v) os preços de cada produto são dados na cidade. Visto que o preço no mercado é fixo e que a região agrícola é supostamente homogênea e isotrópica (que apresenta as mesmas propriedades independentemente da direção), segundo seus pressupostos, o rendimento do agricultor será dado pela função da distância ao centro do mercado (MONASTÉRIO; CAVALCANTE, 2011).

Sem aprofundar a questão matemática, mas a lógica que a ordena, o que se obtém a partir dos pressupostos é uma função linear, formando 
gradientes de rendimento, ou "anéis" no espaço. Caso não haja concorrência para ocupação do solo, qualquer distância das culturas ocuparia todo o espaço, desde o centro de mercado até a distância em que o custo de transporte esgota o lucro bruto da produção. Assim, as culturas que ocupam os anéis mais próximos vão apresentar maiores lucros de produção por unidade de terra ocupada. O custo do transporte relativamente mais alto faz com que 0 rendimento líquido diminua à medida que as áreas mais afastadas são ocupadas, criando gradientes de rendimento negativo, logo, a necessidade de mudar o tipo de cultura. (CLEMENTE; HIGACHI, 2000)

Segundo Thisse (2011, p. 20), "a importância da análise de Thünen para o desenvolvimento da teoria locacional é dupla, pois considera o espaço ao mesmo tempo um bem econômico e um substrato de atividades econômicas", sendo um dos primeiros a teorizar acerca do trade-off que marca essa tradição de pensamento.

Como dito anteriormente, Weber (1929), em seu trabalho seminal Theory of the location of industries, de 1909, incorpora o conceito de "fatores locacionais" de (des) aglomeração e destaca dois tipos de fatores: gerais e específicos. ${ }^{21}$ Os fatores gerais se dividem em regionais e aglomerativos. $\mathrm{O}$ primeiro, argumenta Weber, irá determinar as decisões quanto à localização de atividades industriais, como os custos de transporte e de mão de obra. A partir de uma análise comparativa entre esses dois fatores, obtém-se a localização de mínimo custo, isto é, o custo de transporte considera o custo de reunir os insumos materiais, bem como a distribuição do produto, tendo em vista que há insumos materiais ubíquos, que não acarretam custos de transporte, e insumos que existem apenas em determinadas áreas.

Enquanto os fatores regionais explicam a escolha locacional interregional, os fatores aglomerativos são capazes de explicar a concentração ou dispersão da indústria em uma determinada região, ou seja, a escolha intrarregional. Nesse sentido, os fatores de aglomeração decorrem da redução do custo que uma firma, de certa indústria, aufere ao se localizar junto a outras

21 - Os fatores específicos são deixados de lado, porque não são capazes de contribuir para a explicação geral da teoria de Weber. (CLEMENTE; HIGACHI, 2000, p. 102) 
firmas da mesma indústria. E, seguindo o raciocínio inverso, um fator desaglomerativo representa uma economia de custo obtida pelo distanciamento em relação às empresas já estabelecidas ${ }^{22}$. (CLEMENTE; HIGACHI, 2000, p. 105)

Lösch (1954), por sua vez, contribui para a literatura ao considerar menos relevante a explicação acerca da localização de uma indústria. Ele concentra sua teoria em um modelo de equilíbrio geral para a execução de um planejamento "eficiente", tanto pela ótica do poder público, quanto do setor privado. Nesse sentido, o autor enfatiza que a minimização dos custos não é a variável primordial de uma atividade econômica que determina sua instalação em um determinado lugar, mas sim a maximização dos seus lucros. Isso altera a lógica e os determinantes para a tomada de decisão de uma firma ou indústria, discordando de parâmetros estabelecidos, como os de Christaller. Para Lösch, economias de escala e custos de transporte contrapõem-se, isto é, "a dispersão total não ocorre porque existem economias de escala, capazes de proporcionar custo unitário mais baixo para a produção concentrada [...]", assim como a "concentração total não ocorre porque os custos de transporte a inviabilizam." A maior ou a menor concentração irá depender do predomínio de uma sobre a outra (CLEMENTE; HIGACHI, 2000, p. 110), ou seja, depende de quem sobressai no referido trade-off.

Apesar das diferenças entre Christaller e Lösch, este último, ao criar seu modelo com pressupostos microeconômicos de hierarquia entre áreas de mercado, culmina em um sistema urbano semelhante ao de Christaller. Seu modelo pressupõe um agente monopolista que atua "em seu mercado com consumidores bem distribuídos pelo espaço e um produto vendido que possui alguma elasticidade-preço." Portanto o que marca a diferença entre os dois autores é a diversidade e o número de centros de hierarquia distintos que existe em Christaller, pois Lösch limita a quantidade de centros e sua distribuição no espaço, impondo restrições microeconômicas. (MONASTÉRIO; CAVALCANTE, 2011, p. 59-60)

22 - Conforme Clemente e Higachi (2000, p. 105), essa análise das economias de escala e da concentração industrial é insuficiente, por considerar apenas as vantagens ou desvantagens no âmbito de certa indústria. Dessa forma, Hoover retoma a questão dos fatores (des) aglomerativos classificando-os. 
Apropriando-se de ideias de Thünen, Lösch estabelece a curva de demanda espacial, a partir de uma relação crescente entre distância, preço e quantidade demandada, elabora o chamado cone de demanda, ferramenta pela qual se obtém o volume de receita total do empresário e se define uma racionalidade na tomada de decisões de localização. A diferença entre os dois autores está no fato de que acabam por resultar em fenômenos distintos. Em Thünen, resulta em uma área de produção, enquanto que, em Lösch, um espaço de consumo. Logo, tudo o mais constante, as áreas de mercado serão tanto maiores quanto menores forem a densidade da demanda, a elasticidadepreço e os custos de transporte.

Ao retomar a teoria weberiana, Isard (1949) aperfeiçoa seu modelo. Ambos adotam custos de transporte como principal explicação para a escolha locacional e padrão de distribuição espacial das atividades econômicas. Ponto importante a ser destacado é que, até então, todo processo teórico de localização era de publicação alemã. Isard, sendo estadunidense, traz para o mainstream acadêmico o pensamento que se convencionou chamar de Regional Science. Dessa forma, diversos autores tentam propor novos fatores de localização, com o objetivo de adequar suas teorias à realidade. Isso se torna um marco importante para o campo da economia regional e uma perspectiva mais direcionada aos fatores de aglomeração.

Vale ressaltar que esses aportes teóricos do que foi denominado como Teorias de Localização foram profundamente marcados pelo contexto econômico e social de suas épocas. Uma época ainda inicial do desenvolvimento do capitalismo liberal, com pouca integração entre estadosnação (pouco comércio internacional), marcado por elevados custos de transporte de longas distâncias. Na virada para o século $X X$, com 0 desenvolvimento do capitalismo oligopolista e a difusão do fordismo, o cenário regional se altera e novas teorias precisam ter poder explicativo para um processo que evidenciou cada vez mais a diferenciação dos espaços regionais e os processos de urbanização.

Como visto anteriormente, junto com a queda do Liberalismo, todo um campo teórico doutrinário entrou em crise, o que se traduziu em oportunidades para o desenvolvimento de novas correntes de pensamento. A partir da 
Segunda Guerra Mundial, sob forte influência de Schumpeter e de Keynes, culminou nas chamadas Teorias de Desenvolvimento Regional.

Como expoentes maiores desta renovação teórica, Perroux (1955), Myrdal (1960), Hirschman (1961), entre outros, contrapõem as teorias clássicas de localização, argumentando que estas enfatizavam as decisões locacionais pelo ponto de vista da firma, sem considerar os seus efeitos indutores e condicionadores de novas decisões. (MONASTÉRIO; CAVALCANTE, 2011)

Nesse sentido, a teoria dos polos de crescimento de Perroux (1955) evidencia um papel importante desempenhado pelas inovações na dinâmica capitalista entre as indústrias. Ao denominá-las motrizes, identifica que o aumento das vendas e das compras de serviços não se dá de forma homogênea no espaço. Em outras palavras, os polos de crescimento terão intensidades variáveis, expandindo-se por diversos canais e com efeitos finais também variáveis sobre toda a economia. O autor identifica quatro formas diferentes de polarização, por meio das quais essas indústrias iriam induzir o desenvolvimento regional: técnica, econômica, psicológica e geográfica. (PERROUX, 1955)

\begin{abstract}
A polarização técnica refere-se aos efeitos de encadeamento entre a indústria motriz e outras empresas. Já a geração de emprego e renda decorrente da implantação da indústria motriz seria incluída na polarização econômica. A polarização psicológica, por sua vez, associa-se aos investimentos decorrentes do clima de otimismo gerado pelo sucesso da indústria motriz. Por fim, a polarização geográfica refere-se aos impactos nos sistemas urbanos do desenvolvimento da cidade onde se localiza a indústria motriz; esses impactos levariam à minimização dos custos de transporte e à criação de economias externas de aglomeração. (MONASTÉRIO; CAVALCANTE, 2011, p. 66)
\end{abstract}

Na mesma linha de análise de polos de crescimento, Myrdal (1960) estabelece o princípio da interdependência circular inserido no processo de causação cumulativa ligado ao desenvolvimento regional, evidenciando os efeitos cumulativos na execução de investimentos produtivos. Desse modo, Myrdal aponta que os mecanismos determinantes de concentração produtiva e de investimento ocorrem em áreas já providas de alguma infraestrutura ou atividade econômica. Sem estabelecer um modelo formal, esse princípio 
consiste no desenvolvimento regional divergente entre as economias ao longo do tempo, de modo que alguns mecanismos seriam simultaneamente reforçados pelas forças do mercado. Nesse sentido, destaca a importância da intervenção do Estado para que efeitos difusores e propagadores propiciem o desenvolvimento regional, pois "o jogo das forças de mercado opera no sentido da desigualdade". (MYRDAL, 1960, p. 42)

Um dos pontos chave de sua teoria é trazer uma discussão crítica acerca da diferença entre países subdesenvolvidos e países desenvolvidos (conceito dinâmico e novo à época, em contraponto ao "atrasado" oriundo da concepção de equilíbrio estático e estável das teorias econômicas vigentes). Para tanto, o autor irá trazer elementos que mostram que o conceito de equilíbrio geral (fundamental para o liberalismo e para as teorias clássicas de localização), que até então vigorava, cai por terra, pois é no âmbito da realidade social que as reações se fazem normalmente por meio de desequilíbrios. Em outras palavras, não há como aplicar a hipótese de equilíbrio geral à realidade social, como o processo social tendendo a uma posição que se possa descrever como estado de um equilíbrio entre forças. Logo, a teoria clássica, ao deixar de fora os elementos não-econômicos e caracterizar o modelo somente por fatores econômicos, se mostra limitada. Tal teoria econômica seria deficiente ao não embutir fatores não econômicos, pois os dois fatores estão ligados e devem ser analisado em conjunto.

[...] em geral não se verifica essa tendência à autoestabilização automática no sistema social. O sistema não se move, espontâneamente, entre fôrças na direção de um estado de equilíbrio, mas, constantemente, se afasta dessa posição. Em geral, uma transformação não provoca mudanças compensatórias, mas, antes, as que sustentam e conduzem o sistema, com mais intensidade, na mesma direção da mudança original. Em virtude dessa causação circular, o processo social tende a tornar-se acumulativo e muitas vêzes, a aumentar, aceleradamente, sua velocidade. (MYRDAL, 1960, p. 34)

Além de identificar as diferenças entre países em desenvolvimento distintos, o autor destaca que há semelhanças dessas desigualdades entre países para regiões internas de um mesmo país, por isso, dedica dois capítulos de sua obra, Teoria Econômica e Regiões Subdesenvolvidas, a esse enfoque regional, evidenciando uma "relação causal muito estreita entre as duas" onde 
o papel do Estado se mostra necessário para reequilibrar o sistema (MYRDAL, 1960, p. 53).

Para fundamentar sua teoria (e ecoando as percepções da falência do modelo liberal de desenvolvimento no início do século XX), Myrdal identifica três fatores que evidenciam ser difícil sustentar que tenha havido progresso econômico à época, a partir de um olhar mais amplo, para todo o globo, quais sejam: i) somente um pequeno grupo de países prosperavam e os demais países encontravam-se em situação de extrema pobreza; ii) de forma geral, esse primeiro grupo apresentava crescimento econômico contínuo e/ou sustentável, enquanto que o segundo ou apresentava um progresso mediano e lento ou estagnado, isto é, sem conseguir sair da situação de extrema pobreza; e iii) observou-se que a distância entre o primeiro grupo e o segundo aumentava ao longo do tempo, reforçando a compreensão de que o processo de crescimento econômico possui um caráter cumulativo, causador de divergências.

É nesse ponto que o autor trabalha o princípio da causação circular cumulativa. Myrdal propõe que as teorias ligadas ao desenvolvimento e subdesenvolvimento tinham como referência o círculo vicioso, tendo como pressão contínua de cima para baixo um fator negativo que era simultaneamente causa e efeito de outros fatores negativos. Entretanto, esse processo acumulativo também caminhava para o outro sentido, isto é, ao citar a frase "nothing succeeds like sucess", Myrdal, ao tratar o equilíbrio estável como uma falsa analogia, trouxe para sua análise o processo cumulativo como fator de desigualdades crescentes ${ }^{23}$.

Por serem fatores "multicausais", um elemento que melhora o padrão de vida de uma população irá alterar o seu estado. Desta forma, às vezes as forças cumulativas poderão caminhar na mesma direção, outras vezes, em sentidos opostos, mas também não significa que não haverá momentos de

23 - Para exemplificar o autor discorre sobre a situação dos negros nos EUA. Dois fatores caracterizam o processo de circulação cumulativa da pobreza: o preconceito do branco que causa a discriminação e o baixo padrão de vida da população negra. -são causa e efeito - e ambos os fatores são multicausais. "Os processos cumulativos tendentes à desigualdade regional operam por meio de muitas cadeias causais que, em regra, não são consideradas na análise teórica do jogo das fôrças do mercado. (MYRDAL, 1960, p. 56) 
"repouso", ou em que forças opostas possam se equilibrar por um momento. No entanto, esse momento é ocasional, e novas mudanças ocorrem. O objetivo, portanto, é analisar as "interrelações causais dentro do sistema, à medida que êle se move sob a influência de fôrças externas que pressionam, ora em determinado sentido ora em outro, ao ritmo de seus próprios processos internos". (MYRDAL, 1960, p. 40, grifos nossos)

Essas forças externas, denominadas pelo autor de "comunidade nacional", impulsionam e puxam o sistema continuamente e ao mesmo tempo mudam a estrutura de forças dentro do próprio sistema. Algumas dessas forças constituem as relações de negócios, as oportunidades de emprego, entre outros, que estão sujeitos a "violentas" flutuações a curto prazo. Portanto, a variável tempo "é central uma vez que os efeitos de um choque nas diversas variáveis do sistema se projetam diversamente ao longo do eixo do tempo.". (MYRDAL, 1960, p. 41)

Antes, segue o autor, a escolha locacional tinha relação direta com a geografia do lugar. Depois, em linhas gerais, "o poder de atração de um centro econômico se origina principalmente em fato histórico fortuito”. (1960, p. 52)

Destacando os efeitos regressivos (backwash effects), Myrdal explora três elementos importantes: a migração, o movimento do capital e o comércio. O movimento do capital culmina no aumento das desigualdades, pois onde existirem centros de expansão

o aumento da demanda dará um impulso ao investimento que, por sua vez elevará as rendas e a procura, e causará um segundo fluxo de investimentos, e assim por diante. A poupança aumentará em decorrência das rendas mais altas, mas tenderá a ficar inferior ao investimento, no sentido de que a oferta de capital teria de satisfazer uma ativa demanda. Nas outras regiões, a falta de novo impulso expansionista tem como consequência o fato de a demanda de capital permanecer relativamente fraca, mesmo quando comparada ao volume de poupanças, que será pequeno, porque as rendas também o são e tendem a declinar. Estudos em muitos países revelam como o sistema bancário, quando não controlado para operar de maneira diferente, tende a transforma-se em instrumento que drena as poupanças das regiões mais pobres para as mais ricas, mais progressistas, onde a remuneração do capital é alta e segura. (MYRDAL, 1960, p. 54) 
Da mesma forma, no que se refere ao comércio, este irá se instalar em regiões mais abastadas e onde a ampliação e liberalização dos mercados ofereceram vantagens comparativas às indústrias de centros de expansão que já apresentam remunerações crescentes. (1960, p. 54)

Em oposição aos efeitos regressivos, Myrdal estabelece os efeitos propulsores (spread effects). Eles atuam de forma centrífuga em localidades distantes, de forma a trazer melhores condições para outras regiões que não se colocam como centros de expansão. Como, por exemplo, para as regiões distantes produtoras de matéria prima que irão abastecer as indústrias do centro de expansão ao qual são ligadas. Neste ponto, relaciona esses dois efeitos (regressores e propulsores):

Os efeitos propulsores de um impulso originado de um centro de expansão industrial e propagado a outras localidades e regiões, que operam por intermédio de demandas ampliadas para seus produtos e por muitos outros meios, vinculam-se ao processo social cumulativo pela causação circular, do mesmo modo que os efeitos regressivos, em oposição aos quais êles criaram mudanças compensatórias. Representam uma complicação da principal hipótese, segundo a qual, normalmente, as mudanças nos outros fatores, que nascem como reações provenientes da mudança de um fator, tendem sempre a pôr em movimento o sistema na direção da mudança inicial. [...] Todavia, em nenhuma circunstância os "efeitos propulsores" permitem estabelecer os pressupostos para uma análise de equilíbrio. No caso marginal, as duas espécies de efeitos se compensarão reciprocamente e uma região estará em estagnação. Mas não é de equilíbrio estável essa posição, porque qualquer mudança nas forças em oposição desencadeará movimento cumulativo ascendente ou descendente". (MYRDAL, 1960, p. 59)

Observa-se que é nesse ponto que se evidencia a existência de diferentes níveis de progresso, não só entre países, mas entre regiões. Nos países ou regiões cujo progresso econômico é mais rápido, os efeitos propulsores ocorrerão em velocidade maior. Enquanto que, em países e regiões mais atrasados, tais efeitos tornam-se um obstáculo e um fator de causação de pobreza, reforçando-a.

Portanto, Myrdal destaca a importância de uma intervenção por meio de políticas planejadas e aplicadas no intuito de intervir nesse movimento. Esta medida irá em sentido oposto ao da tendência natural para um equilíbrio de um 
sistema. Nota-se a influência de Keynes em sua teoria, visto que o autor destaca que, se as forças do mercado não fossem controladas por uma política intervencionista, a produção da indústria, o comércio, os bancos, os seguros, enfim todas as atividades econômicas (e isso inclui ciência, arte, educação) ficariam concentradas em determinadas localidades e regiões, deixando o resto do país estagnado.

Insistimos aqui na compreensão da importância de teorizações como as de Myrdal, no seio mesmo da Ciência Econômica. Acompanhando a chamada crise do liberalismo, a ascensão de formas alternativas de pensar a teoria econômica e formas de intervenção para fazer frente às mudanças observadas na economia e na sociedade do pós-Segunda Guerra Mundial, autores como Myrdal fornecem um aparato teórico bastante robusto para se pensar nas implicações regionais e territoriais de tais mudanças, ao mesmo tempo que constituem importantes elementos que fundamentam a atuação em prol do reestabelecimento de formas de equilíbrio, mesmo que sabidamente precárias.

Imbuído da teoria e pressupostos de Myrdal acerca dos efeitos regressivos e propulsores ${ }^{24}$ entre nações e entre regiões do mesmo país, Hirschmam (1961) vai além, ao destacar também a importância das políticas públicas de cunho desenvolvimentista. O autor também parte de alguns conceitos observados e desenvolvidos por Myrdal, como os círculos viciosos. Uma vez constituídos todos os requisitos necessários como condição ao desenvolvimento, seu círculo será provavelmente uma espiral ascendente.

Hirschman ainda destaca que o problema não está centrado na escassez de recursos como obstáculo ao desenvolvimento de uma região, pois o problema se mostra estrutural e não cíclico. Assim, ao invés de focar no "capital e a atividade empreendedora", nossa concepção leva-nos a procurar pressões e processos de incentivo, que farão eclodir e mobilizar a maior soma possível destes recursos". (HIRSCHMAN, 1961, p. 21)

O que o autor quer evidenciar, no capítulo 10, Transmissão Interregional e Internacional, é que, para que haja investimento, há necessidade do interesse

24 - Os efeitos regressivos e propulsores de Myrdal são denominados por Hirschmam de efeitos fluentes e de polarização, respectivamente, apresentando mencanismos similares. 
por parte do setor bancário, isto é, "o desenvolvimento não é entravado pela escassez de fundos e sim pela escassez de elementos bancáveis (negociáveis em banco, ou que representem valor para um banco)". (HIRSCHMAN, 1961, p. 27)

Essa questão reforça alguns pontos colocados sobre o movimento do capital, da forma como trabalhado por Myrdal, como backwash effects que reforçam as desigualdades regionais. Hirschman não deixa de lado a questão da escassez de fundos, sejam estes nacionais ou internacionais. E ainda complementa a relevância na necessidade de recursos no processo de desenvolvimento.

Nesse sentido, Hirschman (1961) estabelece as preferências e estratégias quanto a dois tipos de investimento, capital fixo social e atividades diretamente produtivas, e seus riscos quanto à implantação. Sendo o primeiro fundamental para os desenvolvimentistas no âmbito do desenvolvimento econômico, definese pelos serviços básicos coletivos como educação, saúde pública, transporte, energia, comunicação, entre outros. Postos os pró e os contra de financiar esse ou aquele tipo de investimento, o autor questiona se de fato o primeiro estimula o segundo. Importante lembrar que uma boa infraestrutura se coloca como fundamental como geradora de efeitos locacionais de atração e de instalação de uma atividade industrial, mas seu questionamento indica que são condição necessária, mas ainda não suficiente.

Naquele momento, o autor mostrava que, em países subdesenvolvidos, a poupança e o investimento são relativamente mais interdependentes e, nesse sentido, a realização dos investimentos são menos espontâneos. Dado este fator, fazem-se necessários alguns mecanismos de intervenção para que se criem oportunidades de investimento "induzido" local, em contraponto ao investimento autônomo mais recorrente em países desenvolvidos. Assim, o investimento induzido se tornará mais semelhante a um multiplicador do tipo keynesiano, pois

cada investimento concebe-se como induzindo uma série de investimentos subsequentes e há um elemento de convergência, à medida que a produção das economias externas diminui a cada passo. Isso, entretanto, não significa necessáriamente que os investimentos, êles mesmos, 
convirjam. Não há conexão rígida entre a amplitude de um investimento e o seu input de economias externas, embora se possa esperar existir alguma relação entre estas duas grandezas. (HIRSCHMAN, 1961, p. 114-115)

Essa mesma desigualdade que Myrdal analisa como problema, Hirschmam (1961) considera necessária ou mesmo um requisito para o processo de desenvolvimento, quando questiona o conceito de equilíbrio, pois afirma que economias de aglomeração acarretam efeitos de encadeamento para trás (backward linkanges) e para frente (forward linkanges), impactando as regiões com a implantação de um setor industrial.

Esses dois conceitos tratam das economias de escala necessárias à viabilização de empreendimentos em determinadas regiões. Tendo no primeiro as externalidades decorrentes da implantação da indústria (com o aumento da demanda de insumos no setor a montante), e o segundo que resulta da oferta de insumos, isto é, o encadeamento que beneficia os setores que se posicionam à jusante da indústria instalada.

Se, como visto, as economias de aglomeração foram capazes de embasar a compreensão dos processos subjacentes à formação de cidades na sociedade liberal do pós-Revolução Industrial, o que conferia uma centralidade marshalliana às cidades industriais europeias do século XIX, no momento urbano-liberal; os backward linkanges e forward linkanges conferiram uma centralidade hirschmaniana 25 às metrópoles do século $\mathrm{XX}$, sobretudo do pósSegunda Guerra Mundial, dando embasamento teórico para a compreensão do poder indutor e concentrador das aglomerações industriais, explicando como o espaço de fato se diferencia sob a lógica urbano-fordista. Entre esses dois momentos, Christaller nos forneceu o principal descritor dessas centralidades.

Todos esses autores aqui trabalhados tiveram como preocupação dois pontos em comum e que são centrais em suas respectivas obras:

- Contato/experiência com os problemas socioeconômicos dos países subdesenvolvidos, nas décadas de 1940 e 1950, tendo tido, portanto, a preocupação de entender os mecanismos que levavam às 
desigualdades entre países, com enfoque nos países subdesenvolvidos. Com o fim da Segunda Guerra Mundial, seguido da necessidade de reestruturação dos países europeus ocidentais, a industrialização era percebida como um importante impulsionador do desenvolvimento econômico, mesmo para aqueles países de industrialização tardia;

- Em contraponto às teorias (neo) clássicas de equilíbrio geral/estável. esses autores desenvolveram teorias que trariam mais aderência ao contexto socioeconômico, de cunho mais keynesiano. Nesse sentido, todas as obras aqui trabalhadas se dedicam em algum momento a um ator renegado até então pelo laissez faire: o Estado. Apresentam tanto o seu papel nesse processo de superação do subdesenvolvimento como as políticas intervencionistas necessárias para alterar as forças de mercado que levavam aos desequilíbrios regionais, sejam eles intranacionais ou internacionais.

Mas o que são, efetivamente, esses polos de crescimento que culminavam em efeitos regressivos ou de polarização em uma região ou país? Ainda era preciso explicar melhor o que são esses espaços econômicos que tanto modificam e reestruturam lugares pela perspectiva desses autores, visto que há uma alteração nas relações e fluxos de bens e serviços e o movimento do capital. Como vimos anteriormente, Perroux (1967), influenciado por Keynes e Schumpeter, compreendeu essas novas interações, elaborando o conceito de Polos de Crescimento. Para tanto, o autor tece sua crítica à teoria e aos pressupostos (neo) clássicos, demonstrando que o mainstream teórico tinha pouco poder explicativo na época.

Dado o processo de internacionalização da economia, o princípio de concorrência perfeita já não se adequava à realidade posta. Perroux destacou essas falhas em seu clássico A Economia do Século XX (1967). O ponto central de seu estudo é sua contribuição para um entendimento mais apurado sobre o conceito de espaço econômico. Buscando aproximar-se de uma abordagem sobre o espaço mais próxima da Geografia, ao abandonar a ideia bastante esvaziada que a Economia tem sobre a noção de espaço, de cunho bastante topográfico (isto é, por meio de pontos, linhas, superfícies, volumes etc. ), o autor evidencia a complexidade inextricável das relações das coisas e 
seres humanos. O autor identifica três tipos de espaços: como campo de forças, como de conteúdo de plano e como conjunto homogêneo. (PERROUX, 1967)

Para tanto, Perroux vai determinar a distância econômica como elemento inicial de análise sobre a definição desses espaços. Essa distância é medida em termos monetários, isto é, em preços e custos e terá como fatores de influência no seu cálculo os planos do Estado, da mão de obra e dos concorrentes da empresa. O espaço econômico de uma empresa, portanto, será em primeiro lugar um conjunto de relações que definem o plano da unidade e o plano das outras unidades.

A empresa ocupa um espaço definido como campo de forças que é constituído por centros (polos ou sedes) de emanação de forças centrífugas e recepção de forças centrípetas. Cada centro, que é ao mesmo tempo centro de atração e de repulsa, tem o seu próprio campo, que é invadido pelos campos de outros centros. Sob este aspecto, um qualquer espaço vulgar é receptáculo de centros e ponto de passagem de forças. [...] Neste processo, de atrair pessoas e coisas (espaço vulgar), determina-se a zona de influência econômica, ligada ou não à zona de influência topológica. (PERROUX, 1967, p. 150 grifos nossos)

Ademais, Perroux enfatiza que os espaços monetários também são como campos de forças; no entanto, são mais difíceis de ser detectados no ponto de passagem das forças. Estes espaços são mais fáceis de delimitar "pela representação de 'redes' de pagamento ou pela descrição dos fluxos monetários". (PERROUX, 1967, p. 154-155)

Os centros desses espaços monetários são chamados por Perroux de praças, o que corresponde a bolsas de valores e afins, ou seja, lugares onde se materializariam os fluxos monetários de atração ou origem, assim como seu volume e suas variações. Logo, para Perroux, o espaço econômico nacional não é o território nacional, mas sim "o domínio abrangido pelos planos econômicos do governo e dos indivíduos". Nesse sentido, a nação coloca-se como um ponto de passagem de um campo de forças, como um conjunto de centros ou polos que se originam. (1967, p. 158)

Ao incorporar o Estado e sua definição, Perroux explora o espaço econômico como conteúdo de plano. No início de sua obra, indaga qual seria a 
definição de "economia internacional". Seria um mercado entre nações? Entretanto, a própria definição de nação, para o autor, transpõe barreiras e grupos de indivíduos de um território, em que as nações, constituídas por empresas e indivíduos reunidos em interesses comuns, "formam conjuntos nacionais imperfeitamente comunicantes entre si”. São, portanto, esses atores econômicos que estabelecem um "mercado mundial" nas relações de comércio. Com essa compreensão, tem-se que o espaço econômico nacional é abrangido pelos planos econômicos do Governo e dos indivíduos.

Estes planos económicos, mesmo em regime liberal, são por formas diversas dominantes e dominados e normalmente incompatíveis entre si. A internacionalização destes espaços não consiste portanto numa redistribuição de recursos entre espaços nacionais nem a soma ou combinação de espaços nacionais; consiste em tornar tanto quanto possível e compatíveis os planos económicos dos governos e dos indivíduos. Este esforço levanta as verdadeiras dificuldades e assinala também os verdadeiros resultados. As dificuldades existem, seja qual for o traçado das fronteiras; os resultados podem teòricamente, e sem rectificações de fronteiras, ser conseguidos entre países que aceitam o fundamental da economia de mercado. (PERROUX, 1967, p. 158)

Um ponto chave para entender a complexidade dos espaços econômicos está no movimento e na evolução da moeda (principalmente após a derrocada do padrão-ouro). Perroux destaca que ela se torna internacionalizada ou deslocada na medida em que esses planos são compatíveis e a mando de uma organização ${ }^{26}$.

Desta forma, a partir da noção de espaço econômico, Perroux consegue estabelecer uma explicação bastante robusta para a diferenciação regional, seja entre Estados, regiões ou cidades, dado que, juntamente com os olhos, caracteriza-se, segundo Perroux, como um conjunto de ilhotas de crescimento econômico, cercadas por outros espaços econômicos que estão estagnados.

Boudeville (1961), imbuído dessas definições de espaços econômicos de Perroux, também define os espaços econômicos, mas sem fazer uma separação tão evidente. Enquanto Perroux faz uma distinção entre o concreto

26 - Nesse ponto, Perroux faz alusão à formação da União Europeia, tanto que foi alvo de crítica ao estabelecer e definir os espaços econômicos como conjunto homogêneo. 
(vulgar) e abstrato (espaços econômicos), Boudeville não faz tal separação. Nesse sentido, há diferenças entre os três espaços econômicos propostos, que são denominados são denominados como regiões: homogênea, plano e polarizada.

As regiões polarizadas (régions polarisées) se aproximam do que Perroux denomina campos de forças, de forma menos sofisticada, porém evidenciando desequilíbrios onde se encontram polos dominantes, cuja esfera de influência estabelece uma região heterogênea, uma vez que o desenvolvimento das regiões polarizadas supõe uma divisão de trabalho entre as cidades, entre as demais regiões e mesmo entre nações. O tipo e o fluxo de bens e serviços especializados irão determinar, portanto, suas complementaridades e interdependência à la Christaller, na qual se cria uma hierarquia de regiões polarizadas.

Percebe-se que a definição de região-plano de Boudeville está próxima à de Perroux, mas este incorpora outros planos econômicos que se sobrepõem e que não estão somente na esfera pública, mas ligados aos interesses de "grupos de indivíduos e indivíduos" que terão poder de influenciar a região em questão.

Importante lembrar que esse resultado de regiões polarizadas, representando um processo de diferenciação espacial crescente no processo de alocação de capital fixo, está na base da formação das grandes cidades enquanto locus de produção de um capitalismo oligopolista cada vez mais concentrado em grandes grupos econômicos, o capitalismo fordista, que configura um processo de urbanização especificamente fordista.

Desta feita, evidencia-se que a questão urbano-regional, avançando teoricamente de modo concomitante ao desenvolvimento da sociedade fordista-keynesiana,

[...] havia definitivamente ganhado dimensão estratégica para o crescimento econômico nacional, e o planejamento, tomado de empréstimo da experiência socialista e adaptado ao receituário keynesiano e à democracia burguesa do capitalismo industrial de Estado, tornou-se instrumento central para a propulsão do novo ciclo de desenvolvimento prometido ao final da Segunda Grande Guerra. (MONTE-MÓR, 2006, p. 71) 
No item seguinte, vamos compreender como que a Metrópole se constitui como forma urbana específica desse momento histórico, desse novo ciclo de desenvolvimento.

\subsubsection{A Metrópole como fenômeno da urbanização fordista}

As transformações decorrentes do modo de regulação fordista trouxeram novos contornos para a geografia econômica por meio de processos de urbanização até então nunca vistos. Tem-se a formação de grandes centros urbanos, condição sine qua non para o desenvolvimento do modelo fordista, que no seu desenrolar culminou nas metrópoles. Isso porque, no processo produtivo, a indústria tinha sua localização próxima a grandes centros, tanto para a captação de mão de obra mais qualificada, quanto pela proximidade do consumidor final, aliando produção e consumo de massa. Desta forma, os grandes centros urbanos atendiam tanto às necessidades da acumulação quanto às da reprodução do capital.

Geralmente, a literatura sobre os diferentes momentos e processos de urbanização opera com a noção de "revolução urbana" que "se utiliza para designar diferentes momentos históricos "en los que se suscitan eventos acelerados en la evolución de las ciudades"27 (MARTíNEZ TORO, 2016, p. 80) . Neste contexto, "La denominada revolución industrial ha sido reconocida, extensamente, como un hito clave para explicar y localizar la evolución de la urbanización"28, o que acabou por gerar uma sistematização bastante recorrente em termos, primeiramente, da passagem de um modo de produção agrário para um industrial, a partir da segunda metade do século XVIII, e, posteriormente, para a passagem do mundo fordista para o pós-industrial operado a partir do final do século XX:

La urbanización preindustrial compreende el origen de las ciudades com posterioridade a la revolución del periodo neolítico hasta el inicio de la industrialização em el siglo XIX, la urbanización industrial compreendería desde el início de la industrialización em el siglo XIX hasta la crisis de 1975 y la urbanización posindustrial iría desde 1975, momento de la

27 - que envolvem eventos acelerados na evolução das cidades

28 - A chamada revolução industrial tem sido amplamente reconhecida como um marco fundamental para explicar e localizar a evolução da urbanização 
crisis económica e industrial. $^{29}$ (MARTÍNEZ TORO, 2016, p. 81)

Buscando evidenciar o caráter específico da urbanização industrial e reconhecendo que "No existe un único modelo de ciudad industrial"30 uma vez que que as cidades "no partiron de las mismas realidades geográficas, históricas, demográficas, urbanas, sociales, o económicas"31 (MARTíNEZ TORO, 2016, p. 81), o autor sintetiza o processo, que poderíamos chamar de urbano-liberal, como:

un núcleo urbano que crece de manera compacta por efecto de las fuerzas centrípetas, las cuales generan la doble fuerza de atracción del nuevo empleo industrial del centro urbano y de expulsión de las tierras rurales, por el declive de la producción agrícola, especialmente, siguiendo los ejes de comunicación con la región. ${ }^{32}$ (MARTíNEZ TORO, 2016, p. 82)

Essa "dupla força" de atração e expulsão é justamente o trade-off antes indicado por Thisse (2011) que estrutura a compreensão dos processos de urbanização da passagem dos séculos XIX para o XX. Não que esse trade-off tenha deixado de existir, ele apenas passou, sucessivamente, a ser relativizado por outras forças e dinâmicas também presentes nos processos de urbanização mais recentes, como, por exemplo, o urbano-fordista.

As transformações decorrentes do modo de regulação fordista trouxeram novos contornos para a geografia econômica por meio de processos de urbanização até então nunca vistos. Observa-se a formação de grandes centros urbanos, condição sine qua non para o desenvolvimento do modelo fordista, que no seu desenrolar culminou nas metrópoles. Os grandes centros urbanos atendiam tanto às necessidades da acumulação quanto às da reprodução do capital, agora em uma sociedade de produção e consumo de massa onde

29 - A urbanização preindustrial compreende a origem das cidades com posterioridade à revolução do período neolítico até o início da industrialização no século XIX, a urbanização industrial compreenderia desde o início da induystriuazação no século XIX até à crise de 1975 e a urbanização pós-industrial iria desde 1975, momento da crise econômica e industrial 30 - Não há um modelo único de uma cidade industrial

31 - Não começou a partir das mesmas realidades geográficas, históricas, demográficas, urbanas, sociais ou econômicas.

32 [...] um núcleo urbano que cresce de maneira compacta por efeito das forças centrípetas, as quais geram a dupla força de atração do novo emprego industrial do centro urbano e a expulsão das terras rurais, pela baixa da produção agrícola, especialmente, seguindo os eixos de comunicação com a região. 
el cuarteto coche, frigorífico, aspiradora y lavadora fue fundamental. De acuerdo com Ascher (2004, p. 26), su importância radica em que hizo possible el trabajo feminino assalariado, la compra semanal y la prolongación de las distancias en los desplazamientos cotidianos. ${ }^{33}$ (MARTÍNEZ TORO, 2016, p. 82)

Além das mudanças culturais e de costumes propiciadas pela sociedade de consumo, a própria produção em massa desses bens de consumo duráveis se difundiu, na lógica industrial original de Henry Ford, em linhas de produção de larga escala, absorvendo o grande contingente populacional que passa a ser atraído para essas grandes cidades cujos atributos espaciais passam a ser

la concentratión demográfica en unos pocos centros urbanos sobresalientes en su región y su expansión en 'mancha de aceite' de manera compacta, con estructura metropolitana donde los centros menores de la red urbana se interrelacionan unidireccionalmente con la metrópole, y el orden centroperiferia organiza las relaciones interurbanas de su área de influencia" ${ }^{34}$ (MARTÍNEZ TORO, 2016, p. 82)

No entanto, uma metrópole não é apenas uma cidade grande. $\mathrm{Na}$ passagem do momento urbano-liberal para o urbano-fordista, ambos baseados em distintas características do processo de industrialização, quando se consolidam as metrópoles para algo muito além da própria produção industrial, reforçando-se enquanto polos de desenvolvimento e estruturando hierarquias urbanas,

La ciudad se convirtió, [...] en una unidad socioterritorial con potencialidad para garantizar las economías de aglomeración tecnológica y de escala como mercado, capaz de soportar la creación, difusión y absorción de modernidad y, consiguientemente, de ser nudo socioterritorial de modernidad, hasta producir en algunos lugares de singular desarrollo las extensas, complejas y articuladas metrópoles [...] poniendo valor a los modelos relacionales de centro-periferia y a las

33 [...] o quarteto carro, refrigerador, aspirador e lavadora de roupa foi fundamental. De acordo com Ascher (2004, p. 26), sua importância reside em ter tornado possível o trabalho feminino assalariado, a compra semanal e a prolongação das distâncias nos deslocamentos cotidianos.

34 - A concentração demográfica em uns poucos centros urbanos sobressalentes em sua região e sua expansão em 'mancha de azeite' de maneira compacta, com umna estrutura metropolitana na qual os centros menores da rede urbana se inter-relacionam unidirecionalmente com a metrópole, e a ordem centro-periferia organiza as relações interurbanas de sua área de influência. 
áreas de influencia, $y$ expansivos en mancha de aceite $y$ conurbación"35. (MARTÍNEZ TORO, 2016, p. 82)

Como resultado desse processo, a população mundial considerada urbana passou de cerca de $30 \%$ na metade do século XX para alcançar cerca da $50 \%$ no início do século $\mathrm{XXI}$, demonstrando um crescimento bastante significativo justamente no período entendido como o auge do Fordismo e o início de sua superação. A continuar essa tendência, estima-se que "by the middle of this century all regions will be predominantly urban" ${ }^{6}$ (UNITED NATIONS HUMAN SETTLEMENTS PROGRAMME, 2010, p. IX), com quase todo o crescimento populacional nos próximos 30 anos ocorrendo em ambiente urbano.

Portanto, defende-se aqui uma nuança em relação aos diferentes períodos de urbanização, dado que a apresentação da literatura teórica feita anteriormente nos permite compreender as lógicas do processo de urbanização industrial em dois momentos distintos.

Como vimos, primeiro, o capitalismo liberal, em que a distribuição espacial da produção industrial era guiada, sobretudo, pelo trade-off entre custos de produção e custos de transporte, o que, em uma economia de baixa diferenciação entre os agentes econômicos, promoveu o desenvolvimento de redes urbanas relativamente bem distribuídas, como, por exemplo, na Alemanha do século XIX.

Contudo, com o desenvolvimento do capitalismo oligopolista, baseado na disseminação da produção e do consumo de massa, o processo de diferenciação regional se reforça, as grandes cidades se formam, polarizando grandes regiões e constituindo o fenômeno metropolitano. Portanto, é importante a nuança de que não é a industrialização em si que levou à formação de metrópoles, mas seu estágio fordista, oligopolista, de grandes grupos e do consumo e produção de massa, caracterizando o fenômeno

35 - A cidade se converteu [...] numa unidade socioterritorial com potencialidade para garantir as economias de aglomeração tecnológica e de escala como mercado, capaz de suportar a criação, difusão e absorção de modernidade e, consequentemente, de ser nó socioterritorial de modernidade, até produzir em alguns lugares de singular desenvolvimento as extensas, complexas e articuladas metrópoles [...] pondo valor aos modelos relacionais de centro-periferia e às áreas de influência, e expansivos em mancha de azeite e conurbação .

36 - [...] por volta da metade deste século todas as regiões serão predominantemente urbanas. 
metropolitano como algo específico de uma era, a era fordista, profundamente marcada pela reação "novo liberal" de Keynes. Como vimos,

Esta concepção macroeconômica mais geral influenciou várias interpretações teóricas acerca do desenvolvimento regional e das políticas necessárias para combater os desequilíbrios existentes. Tais teorias postulavam que o desenvolvimento de uma região estaria condicionado pela posição ocupada por esta região em um sistema hierarquizado e assimétrico de regiões, cuja dinâmica estava em grande medida fora da região. Esta era a perspectiva que estava presente nas teorias de centro-periferia e da dependência e modelos de causação cumulativa [...] Estas teorias mostravam claramente os mecanismos que determinavam a concentração do investimento em determinadas regiões em detrimento de outras. De forma semelhante, a abordagem keynesiana também se faz presente na análise de polos de crescimento de Perroux (1955) e Boudeville (1961), que combinam a existência de efeitos acumulativos de escala e aglomeração com efeitos de demanda induzida. (DINIZ; CROCCO, 2005, p. 11)

A seguir, ao apresentarmos nosso exemplo - a cidade de Itaituba veremos o poder dessas teorias em explicar o desenvolvimento urbano do baixo Tapajós no final do século $X X$, para compreender essa dinâmica de urbanização num contexto fordista, com a devida estruturação de centralidades advindas de processos de polarização regional.

Feita essa explanação, na Parte 2 desta tese, argumentaremos que, na virada para o século XXI, com a superação do fordismo, essas mesmas teorias perdem poder explicativo - da mesma forma que as teorias clássicas de localização o perderam com o fim do liberalismo - e um outro arcabouço teórico será mobilizado para estudarmos o processo de urbanização do baixo Tapajós no século XXI.

\subsection{Itaituba e o baixo Tapajós no final do século $X X$}

Como indicado nos objetivos desta tese, Itaituba configura-se como exemplo, que mobilizamos para demonstrar a potência da teorização sobre metropolização para compreender os processos de urbanização contemporâneos. Nesse item, buscamos mostrar a adesão das teorias fordistas ao desenvolvimento urbano da região, discutindo as análises que se apoiam em teorias de desenvolvimento regional de cunho fordista-keynesiano para explicar as configurações e mutações da rede de cidades da região. 
Veremos que essas teorias dão conta de explicar o desenvolvimento urbano do baixo Tapajós no final do século XX e a configuração da rede urbana que se formou, com especial atenção à noção de Grandes Projetos de desenvolvimento, que alteraram, em diferentes momentos históricos, as hierarquias presentes nessa rede de cidades, demonstrando como Itaituba e o baixo Tapajós se inserem na lógica de produção e reprodução do capital.

Para tanto, apresentamos Itaituba e a contextualizamos na região do baixo Tapajós, a partir de dados históricos, territoriais e socioeconômicos.

\subsubsection{Breve contextualização histórica do baixo Tapajós}

A Amazônia brasileira possui dinâmicas socioespaciais bastante complexas e peculiares, devido aos aspectos naturais próprios da região, que conformam um tipo específico de ocupação do espaço. Nesse sentido, destaca-se seu complexo ambiente permeado por rios de águas brancas (Rio Amazonas), águas pretas (Rio Negro) e águas claras (Rio Tapajós), às margens dos quais se formaram aglomerados populacionais e cidades que, em suas dinâmicas, mantêm estreita relação com os rios e as florestas.

No período colonial, foi ao longo desses rios que se edificou o primeiro sistema de controle territorial na Região Amazônica. Esse sistema se deu mediante a construção de fortalezas e o estabelecimento de missões religiosas na região (as ordens jesuíta e carmelita, entre outras), que seguiam os objetivos colonizadores de explorar as chamadas "drogas do sertão", desde que os portugueses perderam o controle do comércio de especiarias do Oriente. Assim, estabeleceram-se nas regiões tanto as missões religiosas quanto as fortificações militares, com objetivo de defender o território do interesse estrangeiro e organizar a exploração local mediante controle da mão de obra indígena. Vale notar que o padrão de colonização estabelecido na região privilegiou a ocupação nas margens e confluências de rios navegáveis, a única forma de escoamento da atividade extrativista. (DIAS, 1972)

Essa situação permanece até meados de 1750, quando o Marquês de Pombal cria a Companhia Geral do Grão Pará, desarticulando as missões religiosas na região. A política pombalina visava articular as fortificações a estratégias como o povoamento nuclear, a criação de unidades administrativas 
e a implantação da agricultura, rompendo, assim, com o extrativismo reinante na região e também com o domínio clerical da exploração extrativista. Desse momento é importante destacar que, como consequência da estratégia pombalina, tem-se a introdução de trabalho de escravos africanos na região, em substituição parcial do trabalho indígena, e a substituição do domínio do clero na atividade econômica.

Os objetivos visados pelo Marquês de Pombal não obtiveram o sucesso esperado com a atividade agrícola e a região continuou tendo como base de suas atividades econômicas o extrativismo de recursos florestais. No entanto, se por um lado a política pombalina não logrou o sucesso esperado em termos de mudanças nas atividades econômicas, por outro operou importantes impactos em termos do ordenamento territorial da região. Como principais mudanças, houve o deslocamento da capital do Estado do Grão Pará da cidade de São Luís para Belém, em 1751, e a criação da capitania de São José do Rio Negro, em 1755. Como observa Corrêa (1987b) a partir desse momento, alguns núcleos interioranos passam a distinguir-se dos demais, seja por suas novas funções urbanas de natureza político-administrativa, seja por meio de funções de natureza comercial e de serviços.

Observa-se, desse modo, que a existência dessa grande rede fluvial conformou a ocupação, a circulação e o controle de recursos do território amazônico desde o século XVII. A importância dos rios como vias de circulação e ocupação do território foi fortemente percebida no século XIX, com o conhecido ciclo da borracha, que impacta fortemente a dinâmica da região.

No que diz respeito à exploração da borracha amazônica, Tourinho (2011) observa que, apesar de vinculada ao capitalismo internacional, essa atividade não se desenvolveu em moldes tipicamente capitalistas de relação assalariada e sim por um sistema que se tornou conhecido como aviamento, caracterizado pelo estabelecimento de

uma cadeia de dependências de dívidas, na qual o trabalhador direto (seringueiro), estava submetido ao proprietário do seringal (seringalista), esse às casas aviadoras, e essas ao capital monopolista internacional, que era quem, em última instância, estipulava os preços e controlava todo o processo de produção. (TOURINHO, 2011, p. 223) 
Diante disso, tem-se a criação de uma economia na Amazônia em que "os principais recursos se encontravam no comércio importador e exportador, bem como nos serviços de transportes". (SANTOS, 1984 apud TOURINHO, 2011, p. 224) Assim, a região passou a exportar borracha para mercados dos Estados Unidos e da Europa, tendo nos rios as principais vias de circulação e (re)ocupação do território, com concomitante proliferação de comunidades ao longo das margens dos rios, construindo modos de vida específicos.

Como decorrência da atividade de extrativismo da borracha na região Amazônica, Corrêa (1987b) observa o surgimento de núcleos urbanos localizados estrategicamente, diante da necessidade de escoamento da produção e das características naturais da região. O autor aponta, ainda, o impulso que as cidades e as redes urbanas ganharam, com o crescimento econômico e populacional de núcleos já existentes - Santarém, Itacoatiara e Parintins - localizados próximos às reservas naturais de borracha, bem como 0 desenvolvimento de benfeitorias urbanas substanciais nas cidades de Belém e Manaus.

No que se refere especificamente ao baixo Tapajós, a partir da década de 1870 a extração da borracha se espalha para o oeste do Estado do Pará, alcançando o baixo Xingu e o baixo Tapajós. A partir da primeira metade do século passado, com o cultivo da borracha em Fordlândia, em 1928, e depois em Belterra, em 1935, muitas mudanças ocorreram na região, já que a empreitada de Henry Ford rendeu a construção de uma cidade planejada na região que hoje pertence ao município de Aveiro, o que trouxe uma série de transformações, ainda que não permanentes, dado o curto período de tempo que durou o investimento norte-americano na região.

Após o fim do ciclo da borracha, outras transformações vão acontecer na região do baixo Tapajós a partir dos anos 1970, em função da abertura da BR-230 (Transamazônica) e BR-163 (Cuiabá-Santarém), no contexto do Plano de Integração Nacional (PIN) ${ }^{37}$, que teve como objetivo promover a integração da Amazônia com o Nordeste e o Centro-Oeste. Essas rodovias, desse modo,

37 - PIN - Plano de Integração Nacional, instituído pelo decreto-lei 1.106 de 16/07/1970. 
passam a desempenhar papel fundamental no processo de reorganização territorial na Região de Integração Tapajós, que será tratada a seguir.

\subsubsection{O contexto territorial da Região de Integração do Tapajós na} segunda metade do século $X X$

Como vimos, a dinâmica de povoamento e estruturação espacial inicial do que hoje é a denominada Região de Integração (RI) Tapajós, onde está inserida Itaituba, remonta ao período colonial e ao posterior ciclo da borracha. Nesse tópico, destacaremos as mudanças no padrão de povoamento regional em suas formas de uso e ocupação a partir do início da década de 1950, que se intensifica a partir da década de 1960, com a chamada Operação Amazônia, que visava à integração da região ao Centro-Sul do país, baseada na doutrina de Segurança Nacional.

Como pode ser observado pelo Mapa 1 abaixo, a RI do Tapajós é constituída por mais cinco municípios, além de Itaituba (Aveiro, Jacareacanga, Novo Progresso, Rurópolis e Trairão) e corresponde a 15,20\% do território

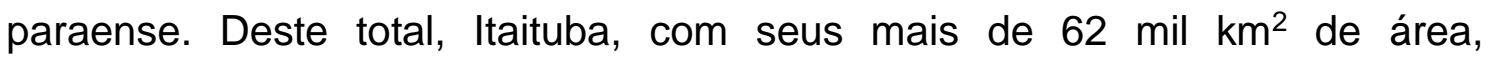
corresponde a cerca de 33\% do total da RI Tapajós:

Mapa 1 - Limites da Região de Integração do Tapajós

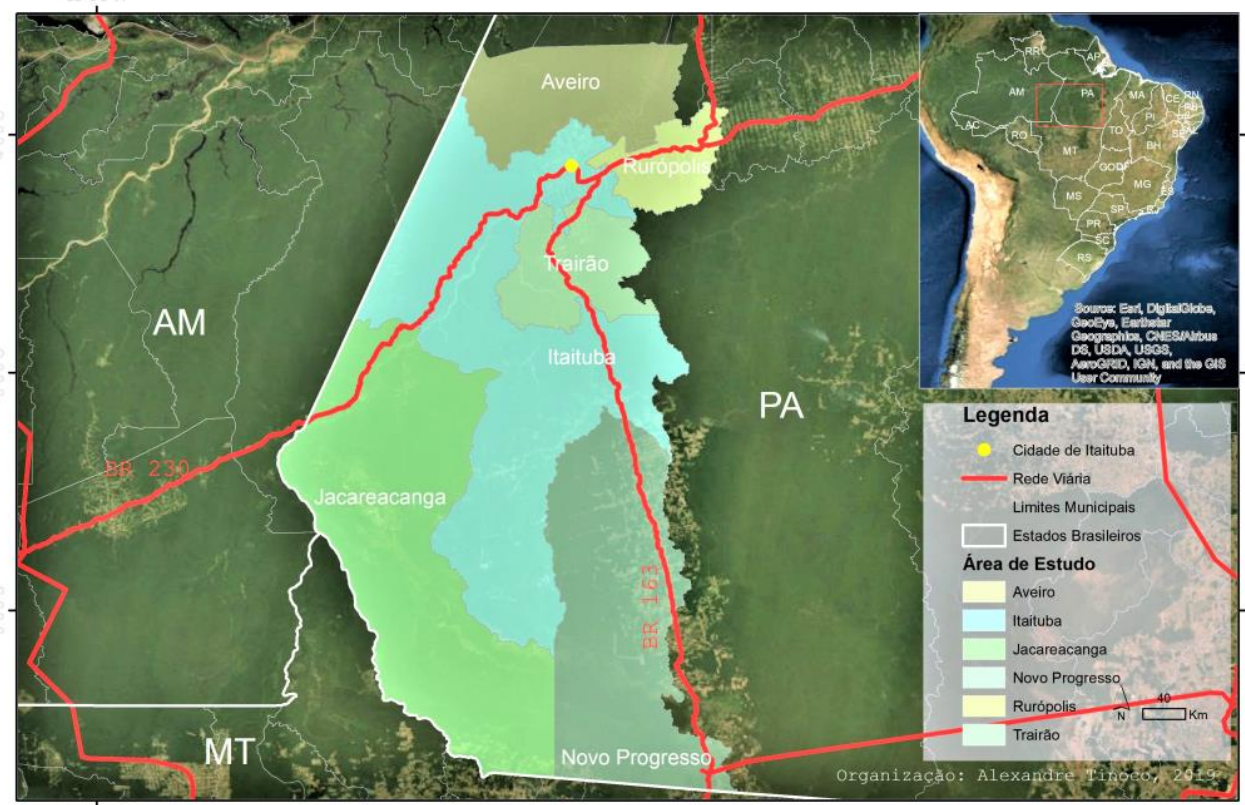




\section{Tabela 1 - Área territorial e população dos municípios pertencentes à RI do} Tapajós

\begin{tabular}{|l|r|r|}
\hline & Área Territorial $\left(\mathrm{Km}^{2}\right)$ & População \\
\hline Aveiro & $17.074,29$ & 15.950 \\
\hline Itaituba & $62.040,95$ & 101.097 \\
\hline Jacareacanga & $53.303,09$ & 8.852 \\
\hline Novo Progresso & $38.162,32$ & 25.124 \\
\hline Rurópolis & $7.021,29$ & 40.087 \\
\hline Trairão & $11.991,02$ & 16.875 \\
\hline RI do Tapajós & $\mathbf{1 8 9 . 5 9 2 , 9 5}$ & $\mathbf{2 0 7 . 9 8 5}$ \\
\hline Pará & $\mathbf{1 . 2 4 7 . 6 8 9 , 5 0}$ & $\mathbf{8 . 3 6 6 . 6 2 8}$ \\
\hline
\end{tabular}

Fonte: IBGE (2010)

O contexto territorial da RI Tapajós é profundamente marcado pelo início do regime militar. As políticas de integração propostas nesse período, dentre as quais se destaca o Programa de Integração Nacional (PIN) e o Programa de Redistribuição de Terras e de Estímulos à Agroindústria do Norte e do Nordeste (PROTERRA) ${ }^{38}$, têm profundas repercussões na Amazônia, em particular no Estado do Pará e na RI do Tapajós, que passam a desempenhar papel de destaque nas políticas de integração nacional.

Nesse contexto, diversas medidas políticas se sucederam entre o final da década de 1960 e início da década de 1980 e, especificamente no que tange à essa região, a federalização atingiu o patamar de aproximadamente 92\% do território (IDESP, 2014), com terras inicialmente transferidas para a alçada federal sob o comando do Instituto Nacional de Colonização e Reforma Agrária (INCRA) para colonização, seguido por um processo que, durante as décadas de 1980, 1990 e 2000, realizou a discriminação dessas áreas por meio da regularização fundiária, a demarcação de terras indígenas e a criação de unidades de conservação federal, de proteção integral e de uso sustentável. (IDESP, 2014, p. 19)

Esse processo de federalização, que passa a ocorrer mais fortemente a partir da década de 1970, se constituiu como condição para a 
operacionalização de políticas de ocupação da terra na RI Tapajós. Como apontamos anteriormente, do ponto de vista da estruturação territorial da RI Tapajós, a criação do PIN processou a expansão da malha rodoviária regional com a construção das rodovias federais BR-230 (Transamazônica) e a BR-163 (Cuiabá-Santarém) e, nesse contexto, a colonização ao longo da BR-230 se deu por meio de um sistema de povoamento de concepção urbano-rural, que previa a construção de vilas e cidades e de assentamentos rurais. O controle territorial serviria para incentivar a ocupação seletiva da terra e para a implantação de projetos de exploração dos recursos naturais (minerais, hidrelétricos e madeireiros). A implantação do projeto integrado de colonização de Altamira e de Itaituba estabeleceu um padrão espacial no qual se associava o assentamento de colonos nos lotes rurais e em lotes urbanos. Esse processo previa um sistema composto de três pequenos núcleos urbanos hierarquicamente posicionados e com funções diferentes e complementares (rurópolis, agrópolis e agrovilas), que deram origem às sedes de municípios criados ao longo das décadas. (IDESP, 2014, p. 19)

Ainda segundo o relatório IDESP (2014), o Decreto Lei ํo. 1.164/71 e o Decreto Lei №. 1.473/76 promoveram a federalização de muitas terras dos Estados da Amazônia Legal, o que representou a transferência para a União de $66 \%$ das terras do Estado do Pará, compreendendo terras situadas na faixa de 100 quilômetros de largura em cada lado do eixo das rodovias construídas, em construção ou ainda em fase de projeto.

O resultado desses processos de federalização e colonização foi o estabelecimento de um novo padrão de organização espacial na RI Tapajós, tendo na estrada seu eixo de estruturação. Esse processo deslocou o centro dinâmico das margens dos rios para as rodovias. Observa-se, com isso, que a introdução de novas atividades - principalmente a agropecuária, a exploração madeireira e a mineração - os novos padrões demográficos, sobretudo pela migração, e o surgimento de novas cidades transformaram o padrão de hierarquização do sistema espacial e da rede urbana regional. (IDESP, 2014) Como mostra Tourinho (2011), a cidade de Itaituba que, junto a Marabá e Altamira, teria a função de servir como ponto de apoio aos grandes projetos de colonização, ficou com o papel de absorver os fluxos migratórios, além de 
receber diversas instituições públicas federais, reforçando seu poder de polarização. (TOURINHO, 2011, p. 247)

Vale notar, no entanto, que, como aponta Tourinho (2011), excetuandose a abertura das rodovias, ainda muito pouco do previsto no PIN foi de fato alcançado. A autora mostra que, dos 70 mil assentamentos previstos, apenas 7 mil foram efetivados, além de a maior parte dos recursos advindos do PIN e PROTERRA terem sido alocados na expansão de rodovias e pavimentação da Belém-Brasília. Ademais, os principais projetos financiados pela SUDAM destinaram-se a empreendimentos de larga escala, favorecendo a instalação de latifúndios e fazendas agropecuárias. (CARVALHO, 1987 apud TOURINHO, 2011)

Ainda sobre o processo acima referido, Théry (2005) argumenta que a expansão de rodovias por meio da ação do Estado transformou profundamente a organização espacial dessa região da Amazônia que até então, dava-se principalmente em torno dos rios. O autor mostra que essa transformação desencadeou um processo no qual se passou "da Amazônia estruturada em função das vias navegáveis, drenando os fluxos para Leste, a uma região dominada pelas estradas que levam ao Sul-sudeste". (THÉRY, 2005, p. 39) Essa mudança, ainda segundo o autor, implicou uma alteração profunda das hierarquias urbanas da região, uma vez que as estradas passam a conectar as cidades da região com outras cidades de fora do contexto amazônico, sobretudo do Centro-Oeste e do Sul-Sudeste do país. Esse movimento altera a hierarquia entre as cidades da região sem, contudo, alterar os pressupostos dessa hierarquia, quais sejam, a centralidade, sobretudo crhistalleriana, baseada no fluxo físico de bens e mercadorias. A distância e o custo de superá-la são as principais chaves de compreensão dessa nova estruturação.

\subsubsection{Características socioeconômicas da Região de Integração Tapajós}

De acordo com o Censo Demográfico de 2010, o Estado do Pará apresenta uma população de 7.581.051. Desse montante, a população da Região de Integração Tapajós possui 209.531 habitantes, que correspondem a 2,76\% da população do Pará, o que equivale a dizer que a Região de 
Integração Tapajós é a menos povoada do Estado, tendo ainda, internamente, uma distribuição populacional irregular. (IBGE, 2010)

Nessa distribuição, o município de Itaituba concentra $45 \%$ da população da RI Tapajós, ou seja, 97.490 habitantes (IBGE, 2010). Vale destacar o fato de que entre 1980 e 1991 a população de Itaituba triplicou, chegando a 116.400 habitantes. Esse processo se deve a um período marcado pela intensificação da atividade aurífera na Região de Integração Tapajós, tendo sido atividade com impacto importante no âmbito local. Já entre 1991 e 2010, observa-se um decréscimo populacional em virtude do arrefecimento dessa atividade econômica.

Os dados censitários para o período entre 1980 e 2000 mostram uma tendência crescente na taxa de urbanização na região: em 1980, a taxa de urbanização correspondia a 44,39\% da população residente na área; já em 2010, essa taxa passou para aproximadamente $56 \%$ da população.

No gráfico a seguir, observamos a evolução da população rural e urbana em números absolutos:

Gráfico 1 - Evolução da população rural e urbana da RI Tapajós

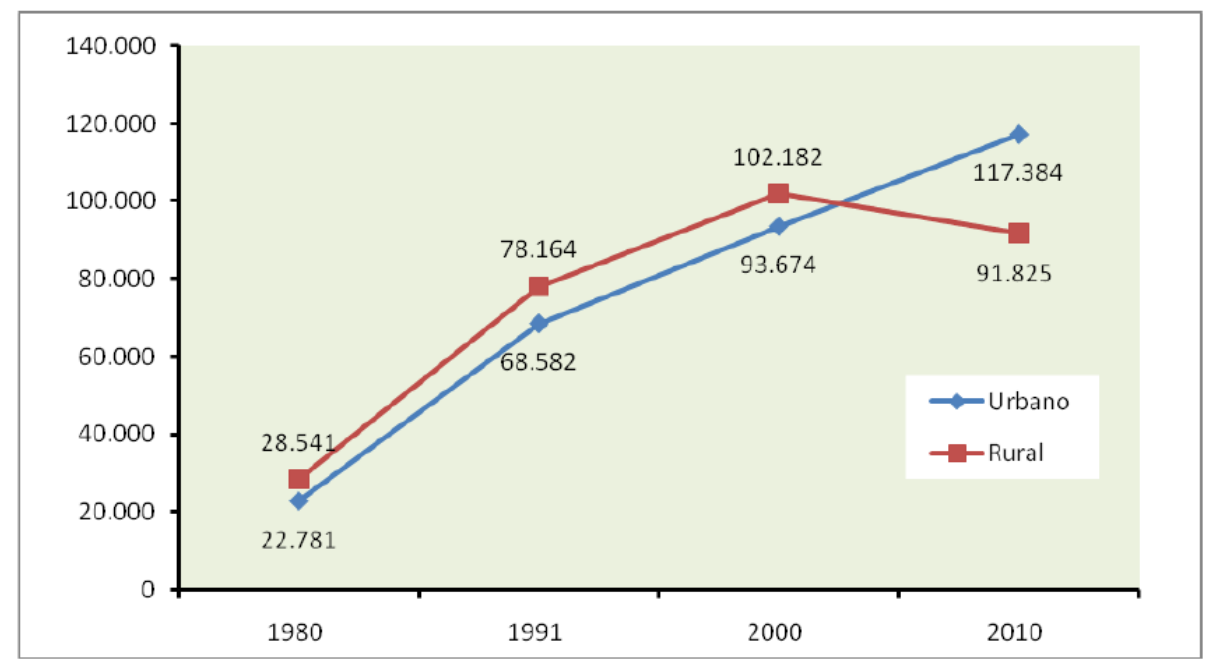

Fonte: IBGE, Censo demografia 1980-2010.

Elaboração: IDESP, 2014.

Ainda segundo o censo de 2010, a distribuição de população na Região de Integração Tapajós corresponde a 47,04\% em área rural e 52,96\% em área urbana. Itaituba e Novo Progresso se destacam entre os municípios com maior grau de urbanização: $72,5 \%$ em Itaituba e $70,52 \%$ em Novo Progresso. Já os 
demais municípios da RI Tapajós apresentam predomínio de população rural, com destaque para o município de Aveiro, que apresenta o índice de $80 \%$ da população em área rural.

Em relação às atividades econômicas presentes na região, em 2016, último ano disponível em termos de Produto Interno Bruto (PIB) municipal no IBGE, a Região de Integração do Tapajós (RIT) produziu mais de $\mathrm{R} \$ 3$ bilhões em bens e serviços a preços correntes, como mostra a Tabela 2. Em 14 anos, desde 2002 até 2016, a região apresentou taxas de crescimento de 14,4\% a.a., acrescentando $R \$ 2,69$ bilhões ao PIB da região. Desse total, Itaituba é o principal impulsionador do crescimento, visto que sua proporção no conjunto dos demais municípios corresponde a mais da metade do PIB.

Tabela 2 - Produto Interno Bruto a preços correntes (Mil Reais) dos municípios que compõem a Região de Integração do Tapajós - RIT

\begin{tabular}{|l|r|r|r|r|r|r|r|}
\hline Ano & Aveiro & \multicolumn{1}{|c|}{ Itaituba } & $\begin{array}{r}\text { Jacare- } \\
\text { acanga }\end{array}$ & $\begin{array}{r}\text { Novo } \\
\text { Progresso }\end{array}$ & Rurópolis & Trairão & RIT \\
\hline 2002 & 18.399 & $\mathbf{2 5 9 . 8 1 8}$ & 29.805 & 82.490 & 55.189 & 35.691 & 481.392 \\
\hline 2003 & 20.479 & $\mathbf{3 2 7 . 9 4 6}$ & 32.980 & 100.211 & 61.274 & 47.000 & 589.890 \\
\hline 2004 & 24.779 & $\mathbf{4 1 9 . 4 8 8}$ & 37.801 & 146.353 & 71.197 & 56.693 & 756.311 \\
\hline 2005 & 32.473 & $\mathbf{4 4 6 . 1 5 6}$ & 41.366 & 151.238 & 74.702 & 56.883 & 802.818 \\
\hline 2006 & 33.157 & $\mathbf{5 2 1 . 1 7 1}$ & 46.686 & 173.060 & 79.215 & 66.106 & 919.395 \\
\hline 2007 & 42.617 & $\mathbf{6 3 2 . 7 9 7}$ & 58.173 & 195.168 & 101.538 & 77.592 & 1.107 .885 \\
\hline 2008 & 53.191 & $\mathbf{6 8 1 . 6 1 8}$ & 70.038 & 165.952 & 109.583 & 80.252 & 1.160 .634 \\
\hline 2009 & 59.929 & $\mathbf{7 2 7 . 7 2 6}$ & 81.677 & 172.774 & 124.066 & 89.038 & 1.255 .210 \\
\hline 2010 & 55.948 & $\mathbf{9 0 6 . 1 0 7}$ & 99.660 & 293.613 & 149.745 & 103.515 & 1.608 .588 \\
\hline 2011 & 66.434 & $\mathbf{9 3 0 . 3 2 2}$ & 113.275 & 296.808 & 172.264 & 133.523 & 1.712 .626 \\
\hline 2012 & 67.953 & $\mathbf{9 2 9 . 6 7 5}$ & 141.010 & 331.148 & 180.425 & 155.088 & 1.805 .299 \\
\hline 2013 & 87.332 & $\mathbf{1 . 1 6 5 . 9 2 7}$ & 159.487 & 355.426 & 229.974 & 201.240 & 2.199 .386 \\
\hline 2014 & 91.998 & $\mathbf{1 . 4 3 3 . 0 5 8}$ & 177.849 & 424.552 & 256.946 & 212.127 & 2.596 .530 \\
\hline 2015 & 97.996 & $\mathbf{1 . 6 0 1 . 8 4 3}$ & 202.240 & 467.114 & 287.612 & 226.746 & 2.883 .551 \\
\hline 2016 & 122.583 & $\mathbf{1 . 6 0 1 . 4 8 5}$ & 237.881 & 560.425 & 341.528 & 309.955 & 3.173 .857 \\
\hline
\end{tabular}

Fonte: IBGE, 2019

Já refletindo a instalação de grandes empreendimentos associados à logística do agronegócio, como veremos a seguir, a participação de Itaituba no total do PIB da região tem oscilado bastante. Isso se deve, sobretudo, às implantações de empreendimentos em Itaituba - que fazem o PIB aumentar significativamente de um ano para outro, ou em outros municípios, que fazem 
com que aumente o PIB total em ano que Itaituba ficou relativamente estável. Esse caráter oscilatório demonstra a magnitude dos empreendimentos que estão sendo inaugurados, bem como as profundas mudanças que poderão acarretar nessa região. Ao longo do período analisado, Itaituba apresenta trajetória de participação crescente com relação à sua Região de Integração, mas depois cai até 2012. Na sequência, sua participação volta a crescer no conjunto da Região até 2015 , ao passo que volta a cair no último período de análise. Importante notar que, de 2008 até 2015, Novo Progresso ganha um pouco mais de espaço no conjunto da RI, enquanto Itaituba perde.

Gráfico 2 - Proporção do Produto Interno Bruto a preços correntes (Mil Reais) de Itaituba em relação a sua RIT e a RIT em relação ao Estado do Pará - entre os anos de 2002 a 2016

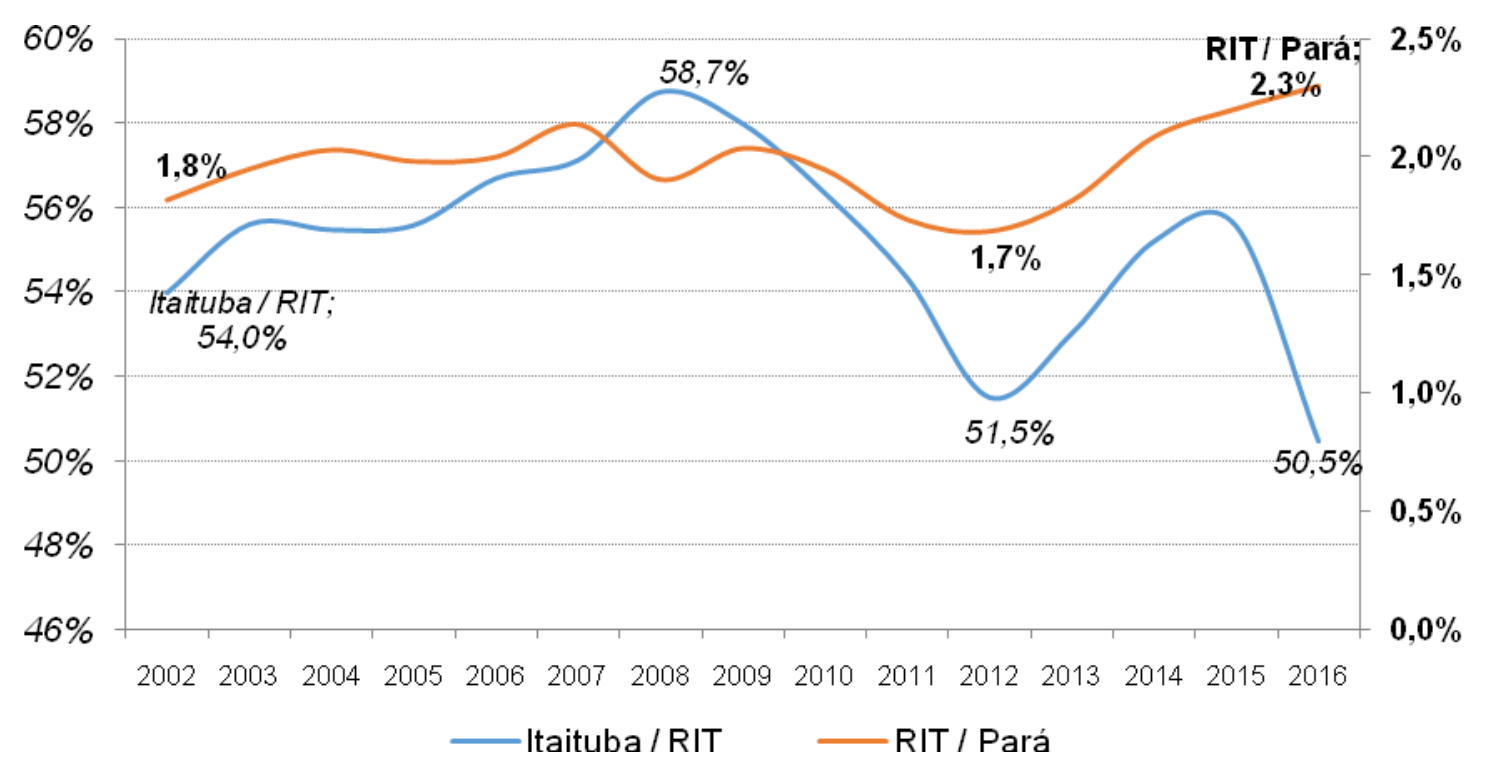

Fonte: IBGE, 2019

\subsubsection{Itaituba: permanências e rupturas}

Apesar de não ser possível afirmar com precisão a data de início da ocupação, registros apontam a existência de povoação na região em 1812, num local onde funcionava um entreposto comercial já denominado Itaituba. $\mathrm{A}$ colonização da região da foz do rio Tapajós pelos portugueses seguiu o processo de estabelecimento de pontos estratégicos de povoamento para garantir a exploração das riquezas extrativistas e o domínio do território contra as incursões de outros povos europeus. Esse local se tornaria uma vila em 
1854 e um município em 1856. Em 1930 seria extinto, voltando a estabelecerse como unidade autônoma em 1935. (IBGE, [S.d.])

Marcada por atividades extrativistas, Itaituba, como todo o baixo Tapajós, também teve grande importância nos ciclos da borracha, tendo sido um dos principais fornecedores da matéria prima para o mercado mundial. Essa importância histórica levou à instalação da chamada Fordlândia em região pertencente aos municípios de Itaituba e Aveiro, quando Henry Ford escolheu o local para a implantação de um seringal em sistema de plantation, visando o abastecimento de borracha para a Ford Motor Company. O projeto não obteve o sucesso esperado devido a uma série de fatores, mas a fundação de uma "cidade" com hospitais, escolas, sistemas de infraestrutura etc. para a exploração do látex ficou no imaginário da população local. Vale notar, entretanto, apesar da riqueza gerada pela extração da borracha, a precariedade das condições de vida e de trabalho dos seringueiros e dos milhares de nordestinos que chegaram à região como trabalhadores dos seringais. (GASPAR, ELIZETE DOS SANTOS, 1990)

Com o fim do ciclo da borracha, a economia do município entra em estagnação até o início do ciclo do ouro, no final da década de 1950, período em que a base produtiva de Itaituba continua focada na economia extrativista, porém com menor produção. (GASPAR, ELIZETE DOS SANTOS, 1990) Apesar de haver registros que indicam exploração de ouro na região do Tapajós já no século XVIII, ainda no contexto das missões jesuíticas (XIMENES; CORREA, 2003), a exploração do ouro ganha maior destaque na atividade econômica local a partir de 1958 e o início dos garimpos leva ao declínio dos seringais, ao mesmo tempo em que abre aos seringueiros uma nova oportunidade, já que, na fase inicial, os garimpos eram pouco mecanizados, exigiam pouca qualificação e puderam empregar os antigos seringueiros, que passaram a trabalhar tanto como funcionários dos garimpos quanto de forma autônoma, seduzidos pelo sonho do enriquecimento. (GASPAR, ELIZETE DOS SANTOS, 1990)

As políticas governamentais de integração implementadas pelo governo militar, na década de 1970, foram sentidas em Itaituba, com repercussões na atividade de garimpo. Vale lembrar que nesse período se destacam a 
construção das rodovias Transamazônica e Cuiabá-Santarém e os projetos de colonização incentivados pelo Estado no âmbito do Programa Integrado de Colonização (PIC). Esse momento marca também o interesse de empresas mineradoras na região, com o processo de expansão da produção de ouro, que combinou a situação favorável de aumento do preço da commodity no mercado com o período de incentivo, pelo Estado, à entrada de empresas na região amazônica, especialmente no Estado do Pará. Ocorre, ao mesmo tempo, a ampliação da mão de obra para os garimpos, com a intensificação da chegada de migrantes para trabalhar nas obras de construção das ferrovias e para fixarse por meio dos projetos de colonização (GASPAR, ELIZETE DOS SANTOS, 1990) e o processo de mecanização da atividade de garimpo, com inserção de novas formas de extração de ouro com impacto na divisão do trabalho entre os funcionários do garimpo e na questão da posse de terras.

Diante de todos esses processos de modernização da região, a cidade de Itaituba passa por grandes transformações, desde urbanização e ampliação do comércio ao aumento da violência e de demandas por serviços sociais $\mathrm{A}$ partir da década de 1990, a produção garimpeira entra em declínio e as atividades agropecuárias e madeireiras entram na pauta da estrutura econômica da região de forma mais intensa (XIMENES; CORREA, 2003) acompanhadas de preocupações com questões ambientais que já haviam começado a ser debatidas durante o ciclo de exploração do ouro, principalmente a utilização do mercúrio, as quais ganham cada vez mais relevância diante das novas formas de exploração econômica da região. (AMORIM, 2013)

\subsubsection{Itaituba e seu momento urbano-fordista}

Como vimos, a consolidação de um aparato teórico de cunho fordistakeynesiano nos permite compreender os processos de urbanização enquanto processos diferenciadores do espaço, geradores de desigualdades e desequilíbrios. Entendendo os grandes projetos como processos deliberados de intervenção estatal visando o desenvolvimento regional da Amazônia nos anos 1960 a 1980, podemos entendê-los como processos que intervêm diretamente no reequilíbrio entre centralidades urbanas, alterando hierarquias e, em última instância, as próprias redes de cidades decorrentes dessas 
hierarquias. Desta forma, encontramos na literatura sobre a região uma grande quantidade de estudos que se dedicam a compreender essas hierarquias e essas redes, avaliando as dinâmicas de constituição e reconstituição de centralidades que estruturam os espaços regionais.

As alterações na rede urbana derivam de um embate entre antigas e novas funções e interações. Da tensão criada surge uma nova rede urbana, na qual formas do passado sobrevivem como resíduos, que desaparecem ou são refuncionalizadas. (CORRÊA, 2012, p. 215)

Grosso modo, historicamente estruturadas pelos rios, as redes de cidades da Amazônia se tornam mais complexas com a chegada de rodovias, por exemplo, instaurando um padrão híbrido onde

a ocupação de terra firme, com novas atividades, a criação de inúmeros centros servidos por rodovias construídas nos divisores de água e o redirecionamento dos novos fluxos geraram uma nova rede que se justapõe à rede urbana dendrítica. A rede urbana amazônica é híbrida, com dois padrões de temporalidade e de organização espacial. Passado e presente, renovação parcial e o novo, nela convivem. (CORRÊA, 2012, p. 215)

A despeito de a literatura mais recente debater se, de fato, há uma rede urbana na Amazônia (SATHLER; MONTE-MÓR; CARVALHO, 2009) e (TOURINHO, 2011), é notório que a região passou por diversas transformações e reconfigurações de sua rede urbana na segunda metade do século XX devido à implantação de grandes projetos de desenvolvimento (TRINDADE JÚNIOR, 2011), (TRINDADE JÚNIOR, 2006) e (CORRÊA, 1987b), inseridos no contexto das "transformações na organização espacial dos países do Terceiro Mundo". (CORRÊA, 1987b, p. 56)

Essas transformações, nas próprias palavras de Corrêa (1987b, p. 58):

[...] referem-se ao aparecimento, em escala mais ampla, de outros modelos de gênese de cidades e de novas funções urbanas, à dependência da rede urbana a um maior número de produtos, e às alterações no tipo de sítio, paisagem urbana e no padrão espacial da rede de cidades: a localização no 'centro', em áreas de 'terra-firme', em detrimento da 'beira', em um terraço de várzea alta, junto a um rio navegável, constituem mudanças que significam, simultaneamente, a valorização de um outro sítio e a ruptura do tradicional padrão espacial dentrítico da rede urbana. 
As redes urbanas na Amazônia são resultado de processos que se sobrepõem no tempo e no espaço. Apesar de Corrêa (1987b) definir sete períodos distintos no desenvolvimento da rede urbana amazônica, dois momentos marcam fortemente esses processos (SOUZA, 2000): datando de antes da década de 1960, o que marca o desenvolvimento dos aglomerados urbanos é o traçado dos rios e os fluxos de comércio e de pessoas por via fluvial; uma segunda fase, associada a grandes projetos de exploração mineral e projetos de colonização, foi impulsionada pela implantação de grandes rodovias a partir dos anos 1960, no que Corrêa (1987b) chamou de "fronteira do capital".

Apesar de uma significativa "explosão urbana nas proximidades das principais ligações rodoviárias" nas últimas décadas (MATOS, 2005), com taxas de crescimento populacional acima das médias nacionais, esses dados devem ser encarados sem

euforia, diante de uma série de peculiaridades que merecem ser exploradas com mais profundidade. Apesar de haver sido estruturada, em algumas porções da Amazônia Legal, uma hierarquia urbana aparentemente similar das demais regiões, com centros regionais claramente distinguíveis, os diversos níveis hierárquicos urbanos apresentam dinâmicas demográficas, socioeconômicas e espaciais distintas daquelas estabelecidas para as redes de cidades do Centro-Sul do País. (SATHLER; MONTE-MÓR; CARVALHO, 2009, p. 11)

Indicando que a "fragilidade das redes urbanas amazônicas" decorre de em um conjunto de "impedimentos para os fluxos de pessoas, mercadorias e serviços" (SATHLER; MONTE-MÓR; CARVALHO, 2009, p. 23), os autores destacam:

Diante das recentes transformações na organização e na estruturação das cidades no território amazônico, à primeira vista pode-se inferir que existe uma rede urbana dinâmica, com várias cidades médias e centros locais com forte poder de interação [...] Entretanto, um olhar mais atento, apoiado em outros argumentos, leva-nos a questionar esta interpretação, cabendo destacar aquele que parece ser o argumento mais imediato: as escalas espaciais da região amazônica são bastante distintas. (SATHLER; MONTE-MÓR; CARVALHO, 2009, p. 22) 
Os autores concluem que "pode-se dizer que pensar em uma única rede urbana amazônica, e toda complexidade que caracteriza uma rede madura e equilibrada, parece impossível" (SATHLER; MONTE-MÓR; CARVALHO, 2009, p. 33), o que implicaria reconhecer que "o eventual sonho de vários planejadores de uma Amazônia integrada talvez nunca se concretize", evidenciando o caráter normativo da abordagem adotada, justamente por partir de uma visão de que, para ser rede, deve ser "equilibrada e madura", sem claramente definir o que significam esses termos, dando a entender que deva existir uma rede ótima que sirva de padrão.

No sentido de buscar compreender as redes urbanas na Amazônia, e não o de buscar o padrão de rede do Centro-Sul na Amazônia (busca que nunca se realiza), é que se insere a perspectiva adotada por Tourinho (2011).

Para a autora, que aponta que essa abordagem "está centrada mais na questão de saber se os centros urbanos amazônicos são ou não dinâmicos e equilibrados do ponto de vista christalleriano", o pressuposto básico é o de que "uma vez que há nós e fluxos, por mais precários que estes sejam, há rede" (TOURINHO, 2011, p. 213), apontando para uma análise mais formal - e menos funcional - da rede urbana.

Entendemos que o debate colocado dessa maneira diz menos sobre o objeto de estudo e mais sobre duas abordagens diferentes acerca do mesmo fenômeno. Por meio de tal perspectiva, Itaituba é entendida não só enquanto um nó inserido em um conjunto de fluxos, mas também enquanto hierarquia que se coloca frente às demais cidades, mesmo que as grandes distâncias dos principais polos nos impeçam de compreender seu papel em uma rede urbana ampliada e estruturada em nível regional mais amplo.

A profusão da literatura acerca das redes de cidades amazônicas é um reflexo direto da magnitude que o processo de urbanização adquiriu nessa região a partir dos anos 1960. De modo geral, somando-se aos estudos de abrangência nacional, como Branco (2003), IPEA, IBGE, \& UNICAMP/IE/NESUR (2001), IBGE (1987, 2000, 2008a), uma série de estudos com foco na rede de cidades amazônicas, como Dias (1972), Ferreira (1977), Oliveira (1983), Corrêa (1987a, 1989, 1990) e Corrêa (2006), Ribeiro (1997, 1998), Browder e Godfrey (2006), Schor \& Costa (2006), Schor, Costa, \& 
Oliveira (2007) e Sathler, Monte-Mór, \& Carvalho (2009), dedicaram-se a entender o processo de produção do espaço regional a partir da compreensão, sobretudo, dos impactos demográficos e econômicos do processo de interiorização do desenvolvimento brasileiro da década de 1960, com a abertura de rodovias e a implantação de políticas explícitas de integração nacional.

A partir da abordagem de rede de cidades buscou-se também compreender o grau de integração das diferentes regiões amazônicas nos circuitos regionais e nacionais. Não é de espantar, devido à magnitude das regiões e distâncias amazônicas, que boa parte desses estudos chegue a conclusões que indicam a ausência de integração entre as diferentes redes de cidades amazônicas e grandes áreas desconectadas dos fluxos predominantes, o que não impede a utilização desse instrumental conceitual para buscar compreender a produção do espaço em uma rede específica, uma vez que consideramos, da mesma forma que (SCHOR; COSTA, 2006, p. 12), que:

[...] a rede urbana será aqui considerada como o conjunto de centros urbanos funcionalmente articulados entre si, algo socialmente produzido, historicamente contextualizado, cujo papel principal é articular a sociedade numa dada porção do território. As cidades não se constituem numa rede funcional em si, mas para si. Quem se estabelece em rede é a sociedade, que tem a cidade como base desse processo.

A rede de cidades de um território se constitui na base material e social de controle e comando de uma região. Por meio de seu estudo, pode-se ter uma aproximação da teia de relações que se estabelece entre as cidades e onde se realiza a satisfação das necessidades econômicas, sociais, culturais e dos diversos produtos e serviços consumidos pela população e pela própria atividade produtiva.

A cidade que atrai mais relações é a que tende a comandar a vida regional e estabelecer uma vida econômica menos dependente da produção local stricto sensu, bem como da sazonalidade física e econômica. É nesse sentido que se pode dizer que uma determinada cidade comanda uma parcela 
do território e é comandada por cidades que estão hierarquicamente acima dela.

A diversificação de funções políticas e econômicas e a disponibilidade de serviços sociais e empresariais, bem como de equipamentos sociais e culturais, forjam a polarização entre as cidades e garantem a posição de entreposto das relações para onde convergem os fluxos e os recursos de um território.

Quanto mais a hierarquização da rede de cidades apresenta diferentes níveis de polarização, menos suscetível ela se apresenta a possíveis modificações de comando em virtude de fatores logísticos, como a implantação de novos acessos rodoviários, ferroviários ou mesmo de novas atividades produtivas que se instalam em territórios vizinhos.

A REGIC 2007 (IBGE, 2008a), a partir do poder de comando metropolitano, identificou doze redes urbanas consideradas de primeiro nível no Brasil. Dentre elas, a de Belém polariza 161 municípios, dos quais 3 são consideradas Capitais Regionais (Marabá, Santarém e Macapá), 11 centros sub-regionais (Redenção e Castanhal do tipo A e Itaituba, Abaetetuba, Altamira, Bragança, Breves, Cametá, Capanema, Paragominas e Tucuruí do tipo B) e 10 centros de zona. A rede de Belém possui "muito baixa densidade, 5,5 hab. $/ \mathrm{km}^{2}$, correspondendo a $4,2 \%$ da população do País". Com uma participação no PIB nacional (2\%) de menos da metade de sua participação na população total, o que a faz atingir um dos menores PIB per capita do país, com $R \$ 5,7$ mil.

Tabela 3 - Características da redes de cidades de primeiro nível - 2007

\begin{tabular}{|c|c|c|c|c|c|c|}
\hline \multirow[b]{2}{*}{$\begin{array}{c}\text { Redes de } \\
\text { primeiro nivel }\end{array}$} & \multicolumn{6}{|c|}{ Dimensão } \\
\hline & $\begin{array}{l}\text { Número } \\
\text { de capitais } \\
\text { regionais }\end{array}$ & $\begin{array}{c}\text { Número } \\
\text { de centros } \\
\text { sub-regionais }\end{array}$ & $\begin{array}{l}\text { Número } \\
\text { de centros } \\
\text { de zona }\end{array}$ & $\begin{array}{l}\text { Número } \\
\text { de } \\
\text { municipios }\end{array}$ & $\begin{array}{l}\text { População } \\
\text { (2007) }\end{array}$ & $\begin{array}{l}\text { Área } \\
\left(\mathrm{km}^{2}\right)\end{array}$ \\
\hline São Paulo & & & & 1028 & 51020582 & 2279108,45 \\
\hline Rio de Janeiro & & & & 264 & 20750595 & 137811,66 \\
\hline Brasilia & & & & 298 & 9680621 & 1760733,86 \\
\hline Manaus & & & & 72 & 3480028 & 1617427,98 \\
\hline Belém & & & & 161 & 7686082 & 1389659,23 \\
\hline Fortaleza & & & & 786 & 20573035 & 792410,65 \\
\hline Recife & & & & 666 & 18875595 & 306881,59 \\
\hline Salvador & & & & 486 & 16335288 & 589229,74 \\
\hline Belo Horizonte & & & & 698 & 16745821 & 483729,84 \\
\hline Curitiba & & & & 666 & 16178968 & 295024,25 \\
\hline Porto Alegre & & & & 733 & 15302496 & 349316,91 \\
\hline Goiânia & & & & 363 & 6408542 & 835783,14 \\
\hline
\end{tabular}
cartografia/default_territ_area.shtm>. Acesso em: mar. 2008.

Fonte: IBGE (2008b) 
$\mathrm{Na}$ análise comparativa com a REGIC 1966, Marabá e Santarém (junto com Macapá) passaram de Centros sub-regionais para a categoria de Capitais Regionais, evidenciando um adensamento da rede urbana da região. Por outro lado, as cidades de Tucuruí, Paragominas e Itaituba aparecem como centros subregionais do tipo B, sendo que constavam na REGIC de 1966 como cidades subordinadas, evidenciando a força do processo do avanço da frente de ocupação amazônica do final do século XX no Pará.

Figura 1 - Rede de influência de Belém - 2007
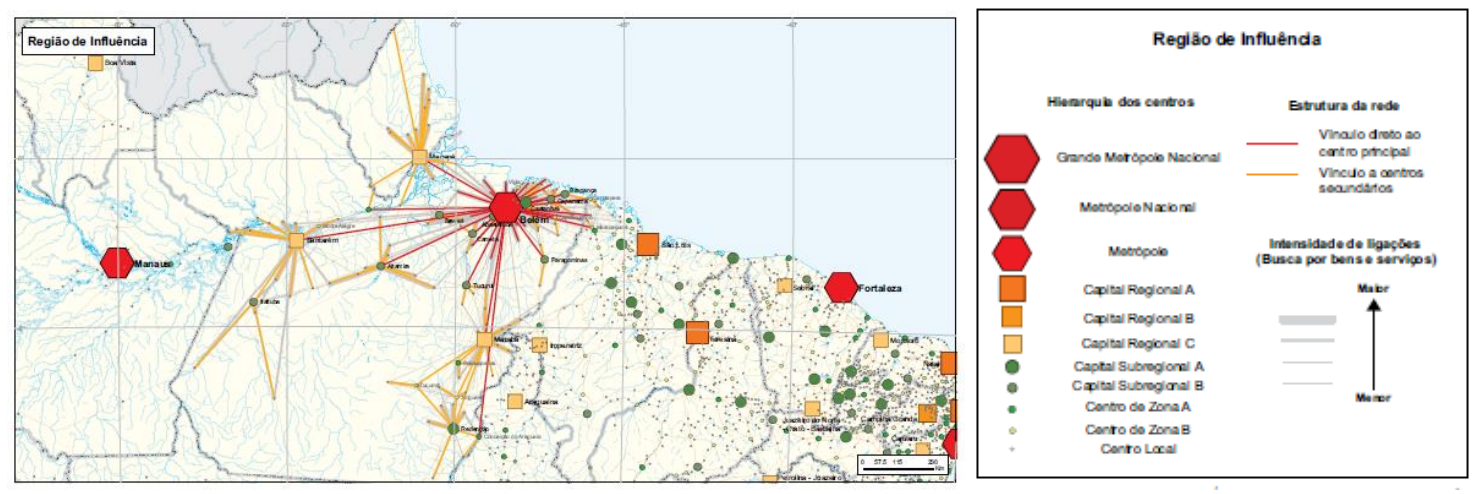

Fonte: IBGE (2008)

Itaituba encontra-se na sub-rede de Santarém. A melhor forma, portanto, de compreendermos as implicações em termos de estruturação desse espaço sub-regional onde Itaituba se insere é examinarmos as para as transformações pelas quais a rede de Santarém vem passando e que são representadas pelas sucessivas REGICs, de 1966, 1987, 2000 e 2007. Tourinho (2011, p. 540), em seu excelente trabalho de sistematização das informações das REGICs para o estudo da urbanização amazônica, sistematiza as mudanças das interações espaciais para cada sub-rede da região. A trajetória de Itaituba aparece claramente no esquema abaixo, referente à sub-rede de Santarém. Nela, Itaituba aparece nas duas primeiras REGICs como cidade subordinada, no último nível da hierarquia espacial. Essa posição reflete o enclave econômico que, mesmo no auge da exploração aurífera, não conseguiu estabelecer conexões mais robustas com as cidades de seu entorno. Até o final dos anos 1970, cidades como Monte Alegre, Óbidos e Oriximiná tinham posição hierárquica superior à de Itaituba. 
Figura 2 - Interações espaciais de Santarém - PA

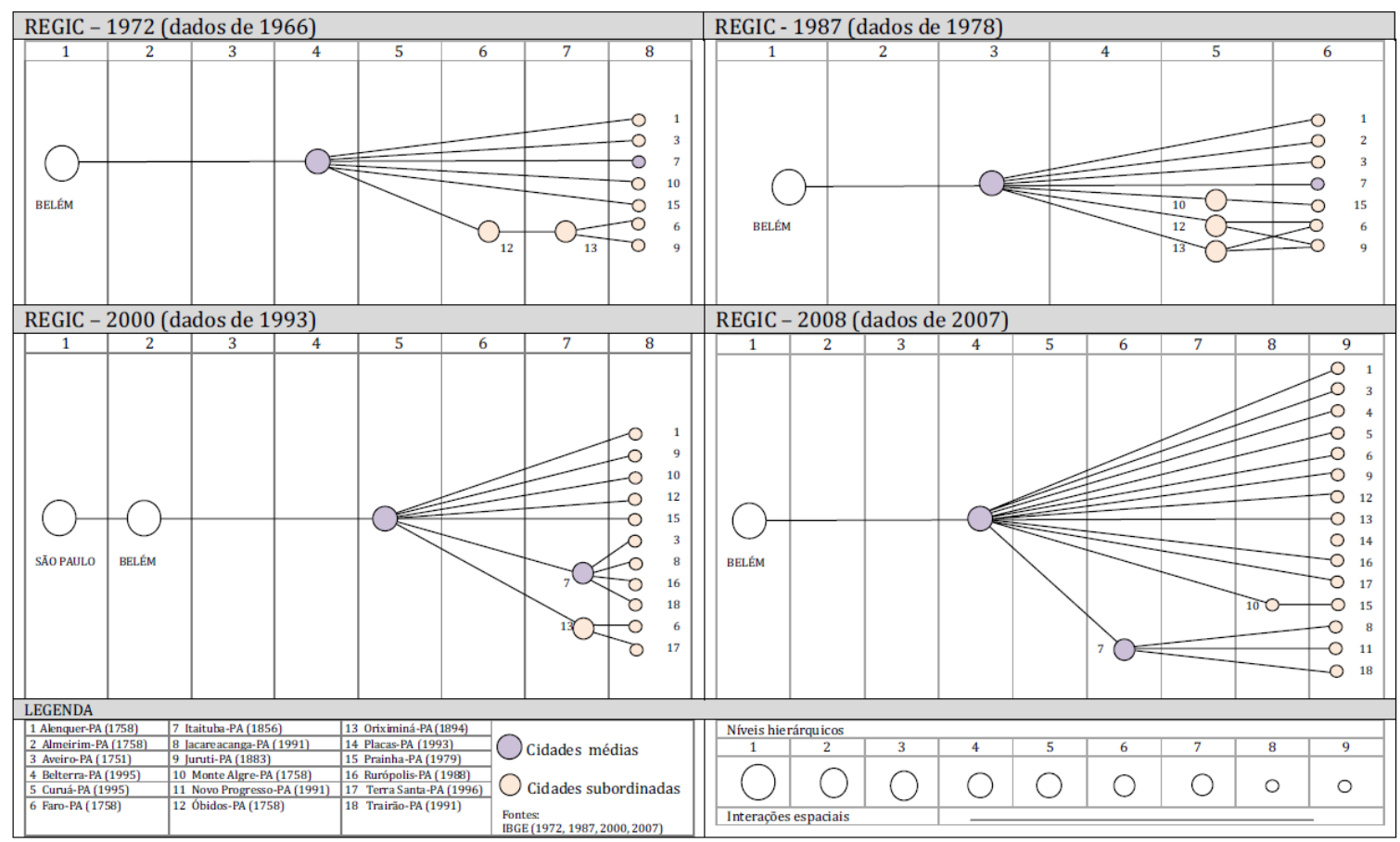

Fonte: Tourinho (2011)

No entanto, já no início dos anos 1990, hierarquicamente Itaituba desbanca Óbidos e Monte Alegre, alçando-se a centralidade de nível 7, um acima dessas cidades, juntamente com Oriximiná e, naquela época, polarizando as cidades de Aveiro, Jacareacanga, Rurópolis e Trairão. Contudo, já como reflexo da expansão do agronegócio e do plantio de soja na região, Itaituba se desprende das demais cidades, ficando relativamente mais próxima de Santarém, isolada como cidade de terceiro nível, não só deixando de ser considerada um enclave (o que já tinha feito na REGIC de 1993), mas também demonstrando considerável poder polarizador.

Toda essa dinâmica espacial evidenciada pela análise das REGICs nos permite compreender a forma desigual com que os Grandes Projetos de desenvolvimento do final do século $X X$ atuaram no território, especificamente no baixo Tapajós. Em geral, na maior parte dos territórios sob impacto de grandes projetos é possível identificar diferentes cenários, dependendo das características e das condições socioeconômicas preexistentes e do tipo de território afetado (se urbano, metropolitano, rural ou de baixa urbanidade). Potencialmente, e de acordo com as Teorias de Desenvolvimento Regional, a implantação de um grande projeto provoca introdução de novas cadeias 
produtivas, crescimento acelerado da economia local, elevação da arrecadação e da poupança fiscal e geração de oportunidades de emprego e novos negócios.

Adicionalmente, no caso específico da relação entre grandes projetos e processos de urbanização na Amazônia, a literatura mostra claramente (TRINDADE JÚNIOR, 2006, 2011), que a forma desigual com que esses projetos são implantados nas diferentes sub-regiões engendra alterações significativas nas dinâmicas territoriais.

\begin{abstract}
Diferentemente da Amazônia ocidental, a Amazônia oriental cresce mais que sua metrópole (Belém), devido ao dinamismo econômico imprimido a outras frações do espaço regional nos últimos anos, onde são implantados projetos, em especial os grandes empreendimentos, que necessitam de espaços urbanos relativamente bem estruturados para 0 seu funcionamento, mas que não se limitam a eles, implicando em redefinições espaciais que alcançam um raio de influência relativamente significativo e que repercutem no grau de urbanização do território. (TRINDADE JÚNIOR, 2006)
\end{abstract}

O autor elenca cinco grandes projetos, implantados no período de 20 anos, entre 1960 e 1980, que teriam, pela incorporação dos fluxos que representam, alterado a estrutura dos nós da rede urbana da Amazônia oriental, quais sejam: Projeto Jari; UHE Tucuruí; Projeto Trombetas; Projeto Carajás e Projeto Albrás. Juntos, teriam promovido a ruptura do padrão de urbanização anterior a 1960.

[...] predominantemente dentrítico com desmesurada primazia de Belém como metrópole regional e uma expansão relativamente pequena da grande maioria dos centros urbanos regionais, em prol de um forte dinamismo das cidades localizadas, ou que passam a surgir, às margens das novas vias de circulação e no entorno de projetos econômicos, em detrimento das cidades ribeirinhas. (TRINDADE JÚNIOR, 2006, p. 184)

Ao discutir a diferenciação entre cidades de porte médio, cidade intermediária e cidade média, propondo que esta última se define pela "importância sub-regional apresentada por uma dada cidade intermediária, ipso facto, pelas fortes centralidades que aí se materializam por meio de fluxos, a ponto de contribuírem significativamente para o ordenamento do espaço 
regional em que se inserem" (TRINDADE JÚNIOR, 2011, p. 136), o autor chama a atenção para o modo como as cidades de Marabá e Santarém consolidaram, de formas diferentes, suas posições enquanto cidades médias, diferentemente das demais cidades impactadas pelos grandes projetos citados acima. À exceção de Tucuruí, as demais cidades que tiveram um crescimento populacional e econômico advindo desses projetos não são capazes de estruturar o espaço ao seu redor, configurando-se como "verdadeiros enclaves urbanos no conjunto da rede urbana", incapazes de a influenciá-la (TRINDADE JÚNIOR, 2011, p. 143), concluindo:

[...] mesmo com status econômico e equipamentos urbanos que as potencializam à condição de cidades médias, não definem polarizações regionais significativas e não se constituem propriamente como centros de distribuição e oferta de bens e serviços, apresentando, portanto, frágeis centralidades econômicas.

A despeito das diferenças metodológicas entre as REGICs, essa mudança de ranking e de hierarquia é bastante significativa dos impactos da implantação de grandes projetos em um determinado território e seus efeitos polarizadores, geradores de novas hierarquias entre as cidades, mesmo que de fraca centralidade.

Vale destacar que a teoria do lugar central de Christaller é a base da REGIC e possui suas críticas: normatividade, premissas de concorrência perfeita, racionalidade dos agentes e planície isotrópica. Portanto, é importante problematizar seu uso para o estudo do processo de urbanização contemporâneo, marcado por elementos que eram ausentes na época das teorizações de Christaller, ao mesmo tempo em que o baixo Tapajós passa por profundas transformações no início do século XXI.

\subsection{Itaituba hoje e novos desafios teórico-metodológicos}

O município de Itaituba hoje é considerado foco de um conjunto grande de investimentos produtivos e de infraestrutura em andamento no Estado do Pará. Dentre eles, destacam-se o Corredor Logístico do Tapajós, associado ao crescimento da área plantada de soja e a viabilização de uma rota de escoamento através de portos da Região Norte; e o Complexo Hidroelétrico do Tapajós. Dada a magnitude desses investimentos, bem como a 
característica peculiar do Corredor Logístico de associar as duas lógicas predominantes na região, quais sejam, a de uma Itaituba histórica, marcada por sua relação com o rio, e a de outra Itaituba que se desenvolveu a partir de sua relação com a estrada, em um momento de grandes transformações do capitalismo, algumas questões se fazem prementes. Uma delas indaga sobre até que ponto as estações de transbordo de carga (ETCs), peças chave do Corredor do Tapajós, ao aproximarem essas duas Itaitubas, estariam representando uma nova forma de produção do espaço regional, para além do modelo existente até o final do século passado, baseada numa lógica pósfordista.

Há a tentação de achar que essas ETCs possam potencializar a integração entre esses dois mundos. No entanto, o que buscamos argumentar nesta Tese é que devem produzir uma terceira lógica, que adiciona a esse território uma camada daquele período metropolitano neoliberal citado na apresentação deste trabalho e que será trabalhado na Parte 2, a seguir.

As respostas a essas questões, no nosso entendimento, virão da compreensão do momento histórico do capitalismo mundial que se instaura com a superação do fordismo, definindo novos fluxos que começaram a chegar ao território de análise no início do século XXI.

Tais fluxos não são mais a resultante da implantação de grandes projetos, dirigidos pelo Estado, numa lógica de integração e ocupação do território nacional, fundada em efeitos polarizadores, e indutores de hierarquias territoriais características do mundo urbano-fordista. Com o advento da hegemonia do neoliberalismo como racionalidade social dominante, esses novos fluxos carregam consigo as novas formas, globalizadas e financeirizadas, de estruturação de cadeias globais de produção de valor, conectando localidades aos circuitos de produção e distribuição de mais-valia, a partir, agora, da implantação dos chamados grandes empreendimentos que, neste novo mundo, assumem o papel de agentes estruturadores do espaço.

Em um mundo caracterizado por relações econômicas, sociais e ambientais globalizadas, um grande empreendimento tende a ser um evento globalizado. A tecnologia que o informa, em geral, deve ter sido desenvolvida em algum centro de Pesquisa \& Desenvolvimento localizado em um país 
central; o financiamento pode ter tido origem em fundos de pensão do hemisfério norte, que usualmente buscam investir em projetos de retorno financeiro de longa duração; os softwares necessários para controlar as operações de instalação e produção são, com frequência, desenvolvidos na Índia; e a manufatura dos bens de capital se dá, principalmente, na Ásia. Apenas a matéria-prima e a mão de obra são locais. Essa é a configuração atual de uma típica cadeia de valor globalizada, na qual diferentes fluxos conectam diferentes nós em diferentes intensidades, independentemente de distâncias físicas.

Desta forma, aquele processo de urbanização que culminou na formação das grandes metrópoles mundiais passa a se defrontar com novas lógicas de produção de espaço, o que nos leva a querer compreender o que é esse processo de metropolização para além das próprias metrópoles (que, por sua vez, entram em crise no mundo pós-fordista).

La metropolización organizada en relaciones de centroperiferia y, espacialmente, en áreas y regiones metropolitanas jerarquizadas por un núcleo dominante y claros contrastes urbano-rurales, constituye un cuerpo teórico en crisis para explicar la urbanización contemporánea que, sin embargo, continúa dominando el imaginario urbano de los investigadores, de los medios de comunicación, de los ciudadanos y de los gobiernos. ${ }^{39}$ (MARTíNEZ TORO, 2016, p. 99)

O enfraquecimento das distâncias físicas como variável relevante aponta para a superação parcial da lógica de redes de cidades, justamente no momento em que Itaituba, pelo interesse de grandes fundos internacionais, se conecta a uma rede de cidades que comandam a economia mundial. Para compreendermos essa passagem de Itaituba de centro regional dentro de uma hierarquia de cidades subordinada a Santarém para Itaituba receptora de investimentos mundializados, é necessário compreendermos as mudanças estruturais pelas quais o capitalismo passou no final do século $X X$ com a

39 - Metropolização organizada em relações centro-periferia e espacialmente em áreas metropolitanas e regiões hierárquicas por um núcleo dominante e claros contrastes urbano-rurais, constitui um corpo teórico em crise para explicar a urbanização que, no entanto, continua a dominar a imaginação urbana dos pesquisadores, os meios de comunicação, os cidadãos e os governos 
superação do fordismo e a consolidação do neoliberalismo como a forma dominante do capitalismo contemporâneo. 


\section{Parte 2 - Da urbanização fordista à metropolização neoliberal}

\section{Introdução}

Contextualizamos teórica e historicamente o surgimento das grandes metrópoles mundiais como fenômeno da urbanização fordista, demonstrando, ao mesmo tempo, que na segunda metade do século $\mathrm{XX}$ a região do baixo Tapajós apresentou um processo de urbanização em sintonia com os mecanismos keynesiano-fordistas de polarização econômica e formação de redes de cidades hierarquizadas, segundo princípios de uma centralidade que poderia ser chamada, então, de hirschimaniana. Agora, nesta Parte 2, temos três objetivos.

Primeiro objetivo: a partir da compreensão da crise do modo de produção fordista, então superado pela consolidação de uma racionalidade neoliberal no capitalismo contemporâneo, buscamos evidenciar o caráter de ruptura existente na passagem do século XX para o XXI. Isso se encontra no item 2.1.

O reconhecimento dessa ruptura implica a aceitação de que essa centralidade, então baseada em preceitos keynesiano-fordistas, também passa por profundas alterações. Uma vez reconhecida e compreendida essa ruptura, vamos discutir as teorias (no âmbito da economia regional e dos estudos urbanos) que buscaram compreender essa mudança, permitindo-nos identificar nas megarregiões a unidade territorial que estrutura e conecta globalmente um conjunto de cidades em rede (e não mais apenas redes de cidades) que organizam a produção global de valor, explicitando as racionalidades da localização das atividades econômicas (segundo as abordagens de cunho mais econômico) ou de formação dos espaços regionais (segundo abordagens de cunho mais geográfico). Essa discussão se encontra no item 2.2. e articula a compreensão da ruptura entre os momentos fordistas e neoliberal do capitalismo com a passagem da centralidade hirschimaniana das metrópoles fordistas para uma nova centralidade, agora associada às megarregiões e ao chamado processo de metropolização. 
Essa nova centralidade será objeto de discussão e apresentação no item 2.3., sendo compreendida como cisão entre os processos de concentração e centralização de capital. Este item tem por objetivo (o segundo) fundamentar uma nova centralidade típica dos processos de metropolização, entendidos como lógica de urbanização do chamado período metropolitanoneoliberal, que se contrapõe ao período urbano-fordista.

Com a discussão e apresentação, o item 2.3. sustenta conceitualmente a especificidade e, desta forma, a ruptura dos processos de urbanização contemporâneos em relação ao processo de urbanização ocorrido na segunda metade do século XX.

O item 2.4 dedica-se, a partir do exemplo do baixo Tapajós, a explorar a potência do arcabouço teórico da metropolização ao se colocar o desafio de buscar capturar as lógicas metropolitano-neoliberais em ambiente não metropolitano.

Da mesma forma que a urbanização-fordista estruturou espaços regionais bastante distantes das grandes metrópoles, que encabeçavam as hierarquias das redes de cidades (item 1.3), postula-se que a metropolização neoliberal estrutura espaços regionais vinculados às megarregiões, que conectam cidades às redes globais de produção de valor, não apenas pela incorporação nesses espaços de conteúdos metropolitanos, mas também, e sobretudo, por incorporarem tais espaços aos fluxos globais de produção e distribuição de valor (item 2.4).

O terceiro objetivo é o de recorrer à compreensão dos processos de urbanização recente do baixo Tapajós para evidenciar aquilo que de mais metropolitano de fato se tem no processo de urbanização contemporâneo. Por mais paradoxal que possa parecer, entendemos que é justamente a capacidade de encontrar lógicas metropolitano-financeiras em espaços não metropolitanos que contribui para compreender a potência desta abordagem. 


\subsection{A crise do fordismo e sua superação pelo neoliberalismo}

No final do século XX, Amin (1994), no primeiro capítulo do livro PostFordism: a reader por ele organizado, estabelece que os novos tempos

... appear to be times of bewildering transformation and change in the structure and organization of modern Western economy and society. It seems that capitalism is at a crossroads in its historical development signaling the emergence of forces technological, market, social and institutional - that will be very different from those which dominated the economy after the Second World War. ${ }^{40}$ (AMIN, 1994, p. 1)

Da mesma forma que um novo mundo surgiu no pós-Segunda Guerra Mundial, com a crise do liberalismo e emergência do keynesianismo, essas transformações pelas quais a sociedade ocidental moderna passava no final do século XX, não sem controvérsias, indicavam a superação desse mesmo keynesianismo reconhecendo-se, na época, que

... there is an emerging consensus in the social sciences that the period since the mid-1970s represents a transition from one distinct phase of capitalist development to a new phase. ${ }^{41}$ (AMIN, 1994, p. 1)

$\mathrm{Na}$ época, reconhecendo e recuperando a miríade de alternativas que se colocavam como possibilidades de descrever essa "nova era do capitalismo" emergente (se pós-fordismo, pós-industrial, pós-moderno, quinta onda de Kondratiev, por exemplo), o autor sumariza a compreensão de que o debate se apresentava "about the putative transition from one dominant phase of capitalist development in the post-war period to another thirty to fifty year cycle of development based upon very different economic, societal and political norms" $\left(A M I N, 1994\right.$, p. 3) ${ }^{42}$, chamando a atenção a que essa transição precisaria ser

40 - Parecem ser tempos de espantosa transformação e mudança na estrutura e na organização da economia e da sociedade ocidental modernas. Parece que o capitalismo está numa encruzilhada no seu desenvolvimento histórico, sinalizando para a emergência de forças- tecnológicas, mercadológicas, sociais e institucionais- que serão muito diferentes das que dominaram a economia depois da Segunda Guerra Mundial.

41 - [...] há um consenso emergente nas ciências sociais de que o período desde a metade dos anos 1970 representa uma transição de uma fase distinta do desenvolvimento capitalista para uma nova fase. 42 - [...] sobre uma suposta transição de uma fase dominante do desenvolvimento capitalista no período pós-guerra para outro ciclo de trinta a cinquenta anos de desenvolvimento baseado em normas econômicas, societárias e políticas muito diferentes. 
compreendida de forma abrangente, não apenas pelo caráter de transição entre processos produtivos, como a ideia de superação do fordismo pode sugerir.

Há pelo menos duas formas de apreensão das características fundantes dessa profunda alteração das normas vigentes do capitalismo. Uma, a partir de seus indícios, apontando que

Estas mudanças abrangem desde novas tecnologias de produção e produto, formas de organização da produção, formas de concorrência, ampliação e aceleração das relações comerciais internacionais, todas com impacto sobre o contexto econômico nacional e internacional, até mudanças nas relações de força entre grupos sociais, novas estratégias de hegemonia política, reformas nos Estados nacionais e novas relações inter-governamentais e internacionais, todas com impacto sobre o contexto político e social. (ARIENTI, 2002, p. 3)

E outra, baseada na compreensão dos fatores que contribuíram para essa mudança. Obviamente, eles possuem variações relacionadas às especificidades dos diferentes contextos nacionais. Segundo Nielsen (1991, p. 24), resumindo as análises de Boyer (1986), existem quatro desses fatores: produtividade, acirramento da globalização, aumento dos gastos sociais e diversificação dos padrões de consumo.

Firstly, productivity gains decreased as a result of the social and technical limits of Fordism (worker resistance to the Fordist organisation of work and increasing difficulties in "balancing" ever longer and more rigid production lines). Secondly, the expansion of mass production led to an increasing globalisation of economic flows which made national economic management increasingly difficult. Thirdly, Fordism led to growing social expenditure (the relative costs of collective consumption increased, because of the inapplicability of mass production methods in this area, leading to inflationary pressures and distributional conflicts). Fourthly, the consumption pattern has gradually changed towards a greater variety of use values (the new demands are at odds with standardization, the basis of economies of scale, and cannot easily be satisfied through mass production methods). ${ }^{43}$

43 - Primeiramente, os ganhos de produtividade decresceram como um resultado dos limites sociais e técnicos do Fordismo (resistência do trabalhador à organização fordista do trabalho e dificuldades crescentes em "balancear" linhas de produção mais longas e mais rígidas. Em segundo lugar, 'a expansão da produção de massa levou a uma crescente globalização dos fluxos econômicos que tornou 
Portanto, as características da nova era que se inicia buscam enfrentar esses quatro fatores. Na literatura, seguindo Amin (1994), encontramos três grandes corpos teóricos que buscaram explicar essas mudanças. Primeiramente, a escola de regulação, buscando elementos que justifiquem a construção de um novo modo de acumulação ou de regime de regulação; em seguida, a escola neoschumpeteriana e sua ênfase nos processos cíclicos associados à inovação tecnológica; e, por último, a vertente da especialização flexível, que põe bastante ênfase na mudança do próprio padrão produtivo da passagem da era do consumo de massa para a era do just-in-time. (AMIN, 1994, p. 6)

A abordagem regulacionista, desenvolvida pioneiramente na França na década de 1970 tinha por objetivo

to develop a theoretical framework which could encapsulate and explain the paradox within capitalism between its inherent tendency towards instability, crisis and change, and its ability to coalesce and stabilize around a set of institutions, rules and norms which serve to secure a relatively long period of economic stability. (AMIN, 1994, p. 7$)^{44}$

A força da escola regulacionista é de que "its theorization of economic development and change claimed to give as much regard to historical processes as to the basic rules of the capitalist economy" (AMIN, 1994, p. 7) ${ }^{45}$, diferentemente de muitas das abordagens no campo da Economia.

Desta forma, como indicado por Arienti (2002, p. 7), de acordo com essa tradição de pensamento,

a administração da economia nacional cada vez mais difícil. Em terceiro, o Fordismo levou a um crescente gasto (despesa) social (os custos relativos do consumo coletivo cresceu por causa da não aplicabilidade dos métodos de produção de massa nessa área, levando a pressões inflacionárias e a conflitos distributivos). Em quarto lugar, o padrão de consumo mudou gradualmente na direção de uma maior variedade de valores de uso (as novas demandas são por desigualdades com padronização, a base de economias de escala, e não podem ser facilmente satisfeitas por meio de métodos de produção de massa).

44 - [...] desenvolver um padrão teórico que pudesse delimitar e explicar o paradoxo no qual o capitalismo, entre sua tendência inerente à instabilidade, crise e mudança, e sua habilidade de aglutinar e estabilizar em torno de um conjunto de instituições, regras e normas, que servem para assegurar um relativamente longo período de estabilidade econômica.

45 - [...] sua teorização do desenvolvimento econômico e mudança exigiu dar atenção tanto aos processos históricos quanto às regras básicas da economia capitalista. 
vários indicadores apontam para a crise do regime de acumulação e modo de regulação fordista nos meados da década de 1970 [...] A estagflação das economias desenvolvidas na década de 1970, o rompimento dos pontos centrais do acordo internacional de Bretton Woods, a crescente reivindicação salarial de trabalhadores sindicalizados além do controle do Estado e da moderação esperada pelos capitalistas, a rebeldia da juventude de classe média aos padrões de produção e de cultura tipicamente fordistas, a decisão autônoma da OPEP de elevar o preço do petróleo, a crise fiscal que atingiu quase todos os governos nacionais e a crise da dívida externa de vários países em desenvolvimento.

Diferentemente da tradição marxista na qual se apoia a escola da regulação, a abordagem neoschumpeteriana se baseia nos ciclos de Kondratiev - períodos de 40 a 60 anos nos quais oscilam fases ascendentes e descendentes de prosperidade, recessão, depressão e melhora. O quarto ciclo de Kondratiev teria correspondido justamente aos 30 anos gloriosos do fordismo, baseado nas tecnologias petroquímicas e na produção automobilística. Um quinto ciclo ter-se-ia iniciado com a revolução das tecnologias da informação. Adicionalmente a essa visão de ciclos longos, essa abordagem retrabalha as contribuições de Schumpeter dos anos 1930 sobre o papel do empreendedor na economia capitalista como agente capaz de promover uma mudança radical de paradigma produtivo, expandindo assim, sucessivamente, o fluxo circular da renda a cada inovação.

Os autores fundadores dessa abordagem são Christopher Freeman e Carlota Perez (FREEMAN, C; PEREZ, 1988; FREEMAN, CHRISTOPHER; CLARK; SOETE, 1982), da Universidade de Sussex, para os quais

the successful transition from one long wave to another is dependent, first, on "quantum leaps" in industrial productivity, which are secured once pioneering advances in technology diffuse across the economy. ${ }^{46}$ (AMIN, 1994, p. 12)

O elemento que diferencia essas duas abordagens é, sobretudo, a importância dada pelos neoschumpeterianos aos processos de inovação tecnológica como elementos capazes de iniciar e sustentar ciclos longos.

46 - [...] a transição bem sucedida de uma longa onda para outra depende, primeiramente, dos "intervalos de quantum" na produtividade industrial, os quais são assegurados uma vez que os avanços pioneiros em tecnologia se difundam através da economia. 
Apesar de possuírem origens tão díspares, Amin (1994, p. 11) postula que há uma concordância bastante grande entre elas e a abordagem regulacionista, sobretudo nos seguintes quesitos:

the systemic and cyclical nature of capitalist development; the periodization and general dynamic of Fordism; the significance of the degree of match between, in neo-Schumpeterian language, the 'techno-economic paradigm' (regime of accumulation) and the 'socio-institutional framework' (mode of regulation); and the stability of a 'long wave' or 'long cycle' of economic development. ${ }^{47}$

Por sua vez, a terceira abordagem, para quem, segundo Amin (1994, p. 13), o recurso à teorias abstratas "is less pronounced than in the preceding two approaches, [...] to avoid emphasizing the role of general structural tendencies in economic and social life, and to reject a deterministic account of historical evolution and transition"48, é associado aos sociólogos norteamericanos Charles Sabel e Michael Piore e se constitui na abordagem da especialização flexível. Para estes, Segundo Amin (1994), a crise do fordismo está relacionada a dois fatores:

The first concerns changes in the market, notably the stagnation of demand in the course of the long recession, growing uncertainty of demand owing to the breakdown of international regulatory mechanisms such as Bretton Woods and, above all, the threat to mass consumerism posed by the growth in demand for non-standardized, better quality, short shelf-life goods. These market trends are said to constitute a problem for mass production and an opportunity for flexible specialization. The second development, also an opportunity for flexible specialization, is the rise of non-specialist and highly flexible manufacturing technologies (numerically controlled as well as non-electronic) and flexible work practices. ${ }^{49}$ (AMIN, 1994, p. 15)

47 - [...] a natureza sistêmica e cíclica do desenvolvimento capitalista; a periodização e a dinâmica geral do Fordismo; a significação do grau de jogo entre, em linguagem schumpeteriana, o "paradigma tecnoeconômico"(regime de acumulação) e a "estrutura sócio-institucional" (modo de regulação); e a estabilidde de uma "longa onda" ou "longo ciclo" de desenvolvimento econômico.

48 - [...] é menos pronunciado do que nas duas abordagens precedentes, em parte devido à tentativa consciente de evitar a ênfase no papel das tendências estruturais gerais na vida econômica e social, e de rejeitar uma avaliação determinista da evolução e transição históricas.

49 - [...] O primeiro diz respeito a mudanças no mercado, principalmente a estagnação da demanda durante a longa recessão, crescendo a incerteza de demanda devido à falência de mecanismos reguladores internacionais, tais como Bretton Woods e, acima de tudo, a ameaça ao consumo de massa posta pelo aumento na demanda por bens de curta duração não padronizados e de melhor qualidade. Considera-se que essas tendências do mercado constituem um problema para a produção de massa e 
Assim, uma era de flexibilidade, a começar pela especialização flexível dos sistemas produtivos, seria inaugurada a partir da derrocada do fordismo. No entanto, segundo Amin (1994), algumas críticas podem ser feitas a essa abordagem, sobretudo porque

the theory is constructed around dual oppositions (mass production versus flexible specialisation) which not only caricature each industrial paradigm (e.g. a rigid past versus a flexible future, unskilled Fordism versus skilled flexible specialisation), but also reduce a great deal of diversity on either side of the divide down to narrowly defined paradigms. ${ }^{50}$ (AMIN, 1994, p. 16)

Evitando esse tipo de simplificação e buscando propor uma análise de "mediação", articulando o capital e o urbano, Abramo (1995) propõe dois conceitos, advindos da escola da regulação que "procuram revelar a articulação geral do capitalismo com a estrutura urbana ('regime urbano') e os modos como essa espacialidade construída se reproduz ('regulação urbana')". (ABRAMO, 1995, p. 511)

Associados à vertente regulacionista que caracterizou o modo de acumulação fordista, bem como as fissuras que indicaram sua superação, conforme visto acima, esses conceitos, que partem da

hipótese de que as relações sociais de produção capitalista
assumem formas históricas e geográficas diferentes ao longo
da "historicidade capitalista" e de que se manifestam nas
maneiras e nas formas de organização e distribuição da
produção comandada pela valorização capitalista [...]
identificam fases particulares da relação do capital e da
estrutura urbana. A "funcionalidade" da estrutura urbana em
relação ao processo de valorização do capital muda ao longo
do tempo e do espaço, em função das características
particulares do regime de acumulação em vigor. (ABRAMO,
1995, p. 511)

uma oportunidade para a especialização flexível. O segundo desenvolvimento, também uma oportunidade para a especialização flexível, é o surgimento de tecnologias manufatureiras nãoespecializadas e altamente flexíveis (numericamente controladas tanto quanto não-eletrônicas) e práticas de trabalho flexíveis.

50 - [...] a teoria é construída em torno de oposições duais (produção de massa versus especialização flexível) que não só caricaturizam cada paradigma industrial (por exemplo um passado rígido versus um futuro flexível, Fordismo inexperiente versus especialização flexível experiente), mas que também reduzem uma grande quantidade de diversidades de ambos os lados da partilha até paradigmas redutoramente definidos. 
Buscando "identificar os principais traços do que poderia ser caracterizado como o regime urbano fordista" Abramo (1995, p. 516) indica dois momentos importantes. Primeiro, o impacto na espacialidade urbana advindo da localização da moradia operária em larga escala. Segundo, essa articulação entre o urbano e o industrial "enfatizaria a dimensão do consumo e, portanto, da realização, em um regime de acumulação caracterizado pela produção em massa, de bens de consumo duráveis."

Por outro lado, quando esse modo de regulação entra em crise, fica a interrogação acerca de que regime urbano se sobreporia ao fordista. A resposta a essa questão surge ao compreendermos a natureza das transformações estruturais contemporâneas. À época das análises de Amin e Abramo a discussão da flexibilização da produção era dominante. No entanto, com o avanço, consolidação e aprofundamento destas transformações, poderemos pensa-las à luz da sociedade neoliberal.

Mas antes iremos buscar compreender a lógica destas transformações contemporâneas relativas à formação de uma Sociedade em Rede, conforme teorizada e sistematizada por Castells (1999), para compreendermos a lógica de configuração da rede das grandes cidades mundiais nesta sociedade flexível.

\subsubsection{A constituição de uma sociedade em rede}

Com a globalização e o declínio do fordismo, as abordagens baseadas na noção de fluxos e na conformação de uma sociedade em rede ganham força explicativa. Com o acirramento do processo globalizante, esses fluxos ganharam status de grandes baluartes da modernidade. Castells (1999) postula, no início de seu trabalho, que "Uma revolução tecnológica concentrada nas tecnologias de informação está remodelando a base material da sociedade em ritmo acelerado. Economias por todo o mundo passaram a manter interdependência global". (CASTELLS, 1999, p. 21) Por esse caminho, o autor destaca que o espaço organiza o tempo na sociedade em rede, onde "espaço e tempo estão sendo transformados sob o efeito combinado do paradigma da tecnologia, da informação e das formas e processos sociais". (1999, p. 403)

Isso porque 
Diferentemente de qualquer outra revolução, o cerne da transformação que estamos vivendo na revolução atual referese às tecnologias da informação, processamento e comunicação. [...] O que caracteriza a atual revolução tecnológica não é a centralidade de conhecimento e informação, mas a aplicação desses conhecimentos e dessa informação para a geração de conhecimento e de dispositivos de processamento/comunicação da informação, em ciclo de realimentação cumulativo entre inovação e seu uso. [...] O ciclo de realimentação entre a introdução, seus usos e seus desenvolvimentos em novos domínios torna-se muito mais rápido no novo paradigma tecnológico. Consequentemente, a difusão da tecnologia amplifica seu poder de forma infinita, à medida que os usuários apropriam-se dela e a redefinem. As novas tecnologias da informação não são simplesmente ferramentas a serem aplicadas, mas processos a serem desenvolvidos. (CASTELLS, 1999, p. 50-51)

O avanço nas telecomunicações, que permite a localização de escritórios ubiquamente, possibilitando sua dispersão no globo, caracteriza dois fenômenos/processos simultâneos: concentração e descentralização em vários países. Desta forma, Castells busca teorizar sobre a emergência de uma lógica espacial que chama de espaço de fluxos, em forte oposição ao tradicional espaço de lugares, com poder explicativo sobre as transformações estruturais pelas quais a sociedade contemporânea vem passando. Mas o que seria esse espaço de fluxos e qual sua importância para a compreensão da sociedade contemporânea?

Para caracterizar esses espaços de fluxos, Castells identifica uma nova forma de espaço industrial. Com o advento da indústria de alta tecnologia, tevese uma nova lógica de localização industrial. Este novo espaço é caracterizado

pela capacidade organizacional e tecnológica de separar o processo produtivo em diferentes localizações, ao mesmo tempo em que reintegra sua unidade por meio de conexões de telecomunicações e de flexibilidade. (CASTELLS, 1999, p. 412)

É nesse espaço que se estabelecem os meios de inovação, como um conjunto de relações de produção e gerenciamento, cujo objetivo é de gerar novos conhecimentos, processos e produtos. Por sua vez, o que irá definir a especificidade destes meios é a capacidade de gerar valor agregado. (1999, p. 413-414) 
Seguindo Castells, a dinâmica que se estabelece dos principais meios de inovação fará com que estes comandem as redes globais de produção e distribuição. Eles irão atuar em cooperação e de forma concorrencial, determinando uma nova divisão espacial do trabalho. Segue disso a descontinuidade fundamental do espaço, decorrente da descentralização da produção, a exemplo das empresas eletrônicas japonesas, para a exportação em âmbito global e para prover suas respectivas matrizes no país de origem. Assim, o novo espaço industrial "é organizado em uma hierarquia de inovação e fabricação articuladas em rede globais". (1999, p. 418)

Após longa apresentação de resultados empíricos de diversas pesquisas, Castells resume que "nossa sociedade está construída em torno de fluxos: fluxos de capital, fluxos de informação, fluxos de tecnologia, fluxos de interação organizacional, fluxos de imagens, sons e símbolos". Tais fluxos não seriam somente mais um elemento da organização social contemporânea, pois "são a expressão dos processos que dominam nossa vida econômica, política e simbólica". (CASTELLS, 1999, p. 436)

A partir dessa constatação, o autor é enfático ao postular que há uma nova forma espacial típica da sociedade em rede: esse espaço de fluxos. Em suas palavras: "O espaço de fluxos é a organização material das práticas sociais de tempo compartilhado que funcionam por meio de fluxos. Por fluxos, entendo as sequências intencionais, repetitivas e programáveis de intercâmbio e interação". (CASTELLS, 1999, p. 501) Grande parte da literatura que Castells usa para fundamentar sua tese é proveniente dos estudos sobre as cidades globais e suas características, como nós mais importantes de uma economia em rede. Essa literatura, ao tentar recuperar a importância do local perante 0 global, enaltece o global frente ao local, apontando a forma pela qual algumas cidades são capazes de controlar os fluxos globais e demonstrando que, assim, recuperam sua predominância no cenário mundial.

Castells destaca que a cidade continua sendo um centro de gravidade para as transações econômicas, mas o que importa é a flexibilidade de suas redes como mecanismo básico de atuação, assim como as economias de aglomeração como fator proeminente de localização. A hierarquia na rede não é, portanto, garantida ou estável, pois ela estará sujeita à concorrência entre as 
cidades. Segundo a teorização de Castells, temos que esse espaço de fluxos pode ser descrito em três níveis de suporte material definidores do espaço. A primeira camada é resultado direto da revolução da microeletrônica e é formada pela constituição de redes de impulsos eletrônicos que são uma infraestrutura tecnológica que expressa o conjunto de fluxos possíveis. Sua segunda camada descritiva são os nós dessas redes ou centros de controle. Aqui, faz uma importante ressalva ao afirmar que "O espaço de fluxos não é desprovido de lugar [...] ", da mesma forma que esses lugares não são desprovidos de interesses específicos. A terceira camada preenche o caráter dos nós que orientam os fluxos de acordo com os interesses das "elites gerenciais dominantes". Ou seja, Castells toma muito cuidado em não teorizar sobre uma espacialidade fluida, desprovida de interesses e com ganho de autonomia perante a sociedade. Busca enfatizar o quão interligadas são as relações sociais dominantes e a espacialização em fluxos da sociedade em rede.

Desta feita, para fazer frente a esse mundo em mutação, novas teorias se desenvolveram, buscando, de alguma forma, incorporar a noção de fluxos informacionais ou, ao menos, ser capazes de abordar economias cada vez mais integradas e conectadas (é o que analisaremos no item 2.2). Assim, seja por fluxos de mercadorias, seja por fluxos imateriais, esse é o pano de fundo que define a estruturação espacial do mundo pós-fordista.

Antes disso, porém, é pertinente indicar que necessitamos configurar a racionalidade contemporânea associada ao novo regime urbano que se inicia com a superação do fordismo, em um momento no qual a sociedade em rede se impõe como marco organizacional global.

\subsubsection{Globalização e urbanização sob a racionalidade neoliberal}

Como visto anteriormente, compreender o modelo de desenvolvimento predominante é fundamental para que se possa compreender os processos de urbanização e de desenvolvimento regional de uma determinada época histórica. Se as teorias clássicas de localização tinham um poder explicativo relevante para o mundo liberal do século XIX; as teorias de polarização passam a ter maior poder explicativo quando passamos para uma economia fordista, associada ao estado de bem estar social. Com o desmanche deste último, 
passa a ser importante compreendermos o sistema político e social que se colocou e vingou, como alternativa, qual seja, o neoliberalismo, para compreendermos o modelo de desenvolvimento associado e, por conseguinte, buscarmos compreender os processos de urbanização contemporâneos.

Sob a lupa da análise de transição, grande parte da literatura foca na transição entre fordismo e acumulação flexível. Entendemos que essa abordagem, embora fundamental e correta, que foca nas transformações do processo produtivo, devido, sobretudo, ao advento de novas tecnologias da chamada Terceira Revolução Industrial, não alcança a totalidade dos processos sociais e políticos envolvidos na transição de um modelo de urbanização fordista e metropolitano para um modelo que seja capaz de dar conta de explicar o surgimento das megarregiões (tema que será discutido no item 2.2). De fato, esse viés tecnológico-produtivo (ao se focar no processo de acumulação flexível) levou muitos estudiosos a, precipitada e equivocadamente, advogar a superação de todas as restrições e "rugosidades" espaciais, tornando a localização dos agentes algo desatrelado do processo de urbanização. A tal ponto que ainda temos de ler reflexões que consideram necessário refutar esse discurso, como, por exemplo, em Florida (2009, p. 1):

It's a mantra of the age of globalization that where we live doesn't matter. The world is flat, says New York Times columnist Thomas Friedman. Thanks to advances in technology the global playing field has been leveled [...] All these technologies have carried the promise of a boundless world. They would free us from geography, allowing us to move out of crowded cities and into lives of our own bucolic choosing. Forget the past, when cities and civilizations were confined to fertile soil, natural ports, or raw materials. In today's high-tech world, we are free to live wherever we want. According to this increasingly popular view, place is irrelevante [...] It's a compelling notion, but it's wrong. By almost any measure, the international economic landscape is not at all flat. Today's key economic factors - talent, innovation, and creativity-are not distributed evenly across the global economy. They concentrate in specific locations. Welcome to the age of the megaregion. ${ }^{51}$

51 - É um mantra da era da globalização dizer que não importa onde nós vivamos. O mundo é chato, diz Thomas Friedman, colunista do New York Times. Graças aos avanços na tecnologia o campo de jogo global foi nivelado [...] Todas essas tecnologias levam consigo a promessa de um mundo sem fronteiras. Elas deveriam libertar-nos da geografia, permitindo-nos sair das cidades povoadas e para vidas da nossa própria escolha bucólica. Esqueça o passado, quando cidades e civilizações estavam confinadas ao solo 
Para fazer frente a essa compreensão do desenvolvimento urbano contemporâneo, pós-fordista, é necessário, além de definir metodologias e técnicas capazes de demonstrar o surgimento e o fortalecimento dessa forma de urbanização chamada megarregião, que é o que, dentre vários outros autores, Florida faz, também compreendermos o funcionamento da sociedade atual que leva a essa configuração espacial das atividades produtivas, tecnológicas ou não. Por isso aqui não adotaremos a passagem do modelo de produção fordista para o de acumulação flexível e sim a passagem do modo de produção fordista para o modo de produção neoliberal, como momentos e lógicas distintas do capitalismo.

Desta feita, partindo de um ponto de vista mais amplo acerca das transformações sociais e políticas engendradas a partir da consolidação do neoliberalismo enquanto uma nova racionalidade, Dardot e Laval (2010b) o definem como

\begin{abstract}
[...] il n'est pas seulement une politique économique qui donne au commerce et à la finance une place prépondérante. II s'agit bien d'autre chose, il s'agit de bien plus : de la manière dont nous vivons, dont nous sentons, dont nous pensons. Ce qui est en jeu n'est ni plus ni moins que la forme de notre existence, c'est-à-dire la façon dont nous sommes pressés de nous comporter, de nous rapporter aux autres et à nous-mêmes. [...] Cette norme enjoint à chacun de vivre dans un univers de compétition généralisée, elle somme les populations d'entrer en lutte économique les une contre les autres, elle ordonne les rapports sociaux au modèle de marché, elle transforme jusqu à l'individu, appelé désormais à se concevoir comme une entreprise $^{52}$. (DARDOT; LAVAL, 2010b, p. 5)
\end{abstract}

Mais do que uma política econômica, o neoliberalismo passa a ser $A$ nova razão do mundo, ou seja, um conjunto de regras e práticas que

fértil, portos naturais ou materiais crus. No mundo high-tech de hoje, estamos livres para viver onde quer que desejemos. De acordo com esse ponto de vista cada vez mais popular, o lugar é irrelevante [...] É uma noção sedutora, mas está errada. Segundo quase todas as medidas, a paisagem econômica internacional de modo algum é plana. Os fatores econômicos-chave de hoje - talento, inovação e criatividade- não estão distribuídos uniformemente através da economia global. Eles se concentram em lugares específicos. Benvido à era da megaregião.

52 - [...] ele não é somente uma política econômica que dá ao comércio e às finanças um lugar preponderante. Bem se trata de outra coisa: da maneira como vivemos, como nós sentimos, como nós pensamos. O que está em jogo não é nem mais nem menos senão a forma de nossa existência,ou seja, a maneira pela qual nós somos pressionados a nos comportar, a nos relacionar com os outros e com nós mesmos. [...] Esta norma leva cada um a viver em um universo de competição generalizada, ela unifica as populações a entrar em luta econômica umas contra as outras, ordena as relações sociais pelo modelo do mercado, transforma até ao indivíduo chamado agora a conceber-se como uma empresa . 
enquadram as relações sociais dentro da lógica do mercado, da concorrência e das escolhas individuais.

Desta forma, a noções de Estado e de governabilidade adquirem novas facetas. Na nova lógica neoliberal, não se questiona qual deve ser o limite do mesmo (assim como do mercado), mas sim "sobre como fazer do mercado tanto o princípio do governo dos homens e como o do governo em si" (DARDOT; LAVAL, 2010a, p. 34). Nesse sentido, o neoliberalismo não se coloca apenas como uma ideologia, mas sim como uma racionalidade que transforma a sociedade em três aspectos: i) econômico - capitalismo financeiro globalizado; ii) político - forças liberais; e iii) social - individualização das relações sociais.

Para os autores, a consolidação do neoliberalismo como "a forma de nossa existência" tem quatro fases. A primeira e mais importante foi chamada de "A Grande Virada" (DARDOT; LAVAL, 2010b, p. 273) e se consubstanciou nos governos Reagan e Thatcher ainda nos anos 1980 (mas também na ditadura de Pinochet no Chile) e foi marcada pelo início da ruptura com o Estado de bem estar social e da Social Democracia que marcaram o período precedente. Segundo os autores:

La politique conservatrice et néolibérale a surtout semblé constituer une réponse politique à la crise à la fois économique et sociale du régime dit "fordiste » d'accumulation du capital. ${ }^{53}$ (DARDOT; LAVAL, 2010b, p. 273)

Como vimos, a crise do sistema fordista foi marcada por uma conjunção inédita de inflação e estagnação econômica, dois processos que historicamente nunca haviam ocorrido simultaneamente e cujo trade-off, representado pelo fato de que políticas expansionistas, apesar de potencialmente inflacionárias, tendiam a dinamizar a economia, promovendo o crescimento, deixou de ocorrer. No modelo keynesiano cabia ao Estado atuar de forma anticíclica, aumentado os gastos (mesmo que pressionando a inflação por aumento da demanda agregada) quando a economia apresentasse sinais de recessão; e reduzindo os gastos nos ciclos de crescimento econômico, a fim de evitar a

53 - A política conservadora e neoliberal pareceu sobretudo constituir uma resposta política à crise simultaneamente econômica e social do regime dito "fordista" de acumulação do capital. 
disparada dos preços e a formação de bolhas especulativas nos mais diferentes mercados.

Tomando a inflação como o grande inimigo a ser combatido, as políticas neoliberais questionaram as políticas de pleno emprego keynesianas e

ont profondément remis en cause la régulation keynésienne macroéconomique, la propriété publique des entreprises, le système fiscal progressif, la protection sociale, l'encadrement du secteur privé par des réglementations stricts, spécialement en matière de droit du travail et de représentation des salariés. (DARDOT; LAVAL, 2010b, p. 273) ${ }^{54}$

Mais do que uma substituição de um arcabouço teórico por outro, no caso o keynesianismo ser substituído pelo monetarismo de Milton Friedman (como muitas análises fazem), para Dardot e Laval (2010b, p. 278) a compreensão de como a lógica generalizada da concorrência dominou todas as esferas da vida humana e social em nível mundial passa pelo entendimento de que o neoliberalismo é um projeto político que se acoplou à dinâmica endógena (tecnológica, comercial e produtiva) do desenvolvimento do capitalismo do final do século XX. Sem essa simultaneidade, sua disseminação não teria sido possível.

Enquanto projeto político, o neoliberalismo se apoia profundamente nos preceitos de Milton Friedman que preconiza que, para que seja possível a superação da estagflação keynesiana, é necessário implantar mecanismos de quebra dos processos de indexação salarial, marcantes do Estado de bem estar social, e fortemente ligados à força dos sindicatos, visando lutar contra a inflação galopante e promover a recuperação das taxas de lucro. Ambos os objetivos visavam tornar a economia mais competitiva e atraente para 0 investimento e, consequentemente, para a geração de emprego, e foram adotados junto com grandes e abrangentes processos de privatização de empresas públicas (sempre com o discurso de que setor privado tem melhores condições de gestão e, consequentemente, mais lucratividade do que o setor

54 - Questionaram profundamente a regulação keynesiana macroeconômica, a propriedade píublica das empresas, o sistema fiscal progressivo, a proteção social, o enquadramento do setor privado por regulamentações estritas, especialmente em matériade direito trabalhista e de representação dos assalariados. 
público) e mudanças legais e regulatórias visando a desregulamentação da atividade econômica.

Poder-se-ia dizer que esse cenário seria um retorno ao liberalismo do século XIX, do laissez-faire mais radical e generalizado, um retorno ao Estado mínimo. No entanto, o que Dardot e Laval (2010b) pretendem demonstrar é que, diferentemente do liberalismo clássico, o neoliberalismo não implementa um Estado mínimo. Diferentemente disso, indicam que a lógica da concorrência passa a ser a própria lógica do Estado e que essa se espraia para o conjunto da sociedade. O Estado tem sim o papel forte de garantir a implantação e o domínio das regras de concorrência em todos os âmbitos da vida social e econômica. É a livre concorrência como política de Estado.

Esse processo de progressiva internalização da lógica da concorrência em todos os âmbitos sociais, fomentada pelo Estado, acoplou-se em profundas mudanças do capitalismo do final do século passado que permitiram sua amplificação para escalas e esferas nunca antes atingidas.

Segundo os autores, as principais características dessa dinâmica endógena de transformação do capitalismo são a mundialização e a financeirização:

Sur le plan mondial, la diffusion de la norme néolibérale trouve un véhicule privilégié dans la libéralisation financière et la mondialisation de la technologie. Um marché unique des capitaux se met en place à travers une série de réformes de la législation, dont les plus significatives ont été la libération complète des changes. ${ }^{55}$ (DARDOT; LAVAL, 2010b, p. 283)

Portanto, estamos aqui falando de dois processos. Primeiro, da própria financeirização em si e de sua importância como modelo de desenvolvimento que, como veremos adiante, tem profundas implicações para os processos de urbanização contemporâneos. No entanto, uma das grandes contribuições de Dardot e Laval (2010b) é argumentar como o desenvolvimento da financeirização se transforma em indutor do neoliberalismo como norma social

55 - No plano mundial, a difusão da norma neoliberal encontra um veículo privilegiado na liberalização financeira e na mundialização da tecnologia. Um mercado único de capitais põe-se em cena através de uma série de reformas da legislação das quais as mais significativas foram a liberdade completa das trocas. 
e, portanto, também individual, formatando a base das relações sociais e, com isso, definindo uma racionalidade tanto de empresas quanto de indivíduos.

Os autores lembram que, inicialmente, "Cette libéralisation politique de la finance est fondée sur un besoin de financement de la dette publique » (DARDOT; LAVAL, 2010b, p. 283), ${ }^{56}$ mas que, a partir de «une révision progressive de la politique monétaire américaine qui a abandonné les stricts canons du monétarisme doctrina"57, o mercado financeiro se torna independente das variáveis reais (produção e consumo) da economia mundial, apresentando um volume bastante elevado e uma lógica própria.

No entanto, a economia real não fica alheia ao mercado financeiro, muito pelo contrário:

Le passage du capitalisme fordiste au capitalisme financier a également été marqué par une modification sensible des règles de contrôle des entreprises. Avec la privatisation du secteur public, le poids croissant des investisseurs institutionnels et l'augmentation des capitaux étrangers dans la structure de la propriété des entreprises, l'une des transformations majeurs du capitalisme réside dans les objectifs poursuivies par les entreprises sous la pression des actionnaires [...] Selon cette logique, la "création de valeur actionnaire ", c'est-à-dire la production de valeur au profit des actionnaires telle que les marchés boursiers la déterminent, devient le principal critère de gestion des dirigeants. ${ }^{58}$ (DARDOT; LAVAL, 2010b, p. 284)

Nesse processo, o mercado financeiro se constituiu, nas palavras dos autores, em um "agent disciplinant por tous les acteurs de l'entreprises, depuis le dirigeant jusqu'au salarié de base"59 e, dessa forma, foi um indutor da racionalidade neoliberal em todo o tecido social.

56 - Esta liberalização política das finanças está fundada sobre uma necessidade de financiamento da dívida pública.

57 - [...] uma revisão progressiva da política monetária americana que abandonou os cânones estritos do monetarismo doutrinário.

58 - A passagem do capitalismo fordista ao capitalismo financeiro foi igualmente marcada por uma modificação sensível das regras de controle das empresas. Com a privatização do setor público, o peso crescente dos investidores institucionais e o aumento dos capitais estrangeiros na estrutura da propriedade das empresas, uma das transformações maiores do capitalismo reside nos objetivos perseguidos pelas empresas sob a pressão dos acionistas[...] Segundo essa lógica, a " criação de valor acionário" , isto é, a produção de valor em proveito dos acionistas tal qual os mercados bolseiros a determinam, torna-se o principal critério de gestão dos dirigentes.

59 - [...] agente disciplinador para todos os atores das empresas desde o diretor até o assalariado de base. 
Esta visão acerca da relação entre financeirização e neoliberalismo contrasta com muitas leituras que ou os equiparam, tratando-os como sinônimos, ou tratam o efeito pela causa, ao identificar o neoliberalismo como subproduto da financeirização, numa análise que dá a entender que os mercados, com a financeirização, se autonomizam e subjugam os Estados. $\mathrm{Na}$ realidade, a leitura é mais complexa, e a proposta de Dardot e Laval (2010b, p. 286) é a de que

Le nouveau capitalisme est profondément lié à la construction politique d'une finance globale régie par le principe de la concurrence généralisée. En cela, la "mise en marché" (marketization) de la finance est fille de la raison néolibérale. ${ }^{60}$

Muitos analistas chegaram a crer que, com a crise mundial de 2008 (originada nas finanças), que inaugura a segunda fase, o neoliberalismo demonstrava seu esgotamento, o que abriria as portas para sua superação. No entanto, muito pelo contrário, a crise acabou sendo uma oportunidade para se reforçar a disseminação do neoliberalismo pela sociedade. Construiu-se um discurso dominante que a culpa pela crise não era do neoliberalismo (ou de seus preceitos, como a primazia da lógica da concorrência em todas as esferas), mas sim o contrário, que a culpa era a não penetração ampla dessas lógicas. Desta forma, na terceira fase, propostas políticas, mesmo da chamada esquerda, se viabilizaram com discursos, posições e ações que reforçaram e fortaleceram a lógica neoliberal.

$\mathrm{Na}$ quarta fase, a partir de 2016, o neoliberalismo acabou por conseguir se expressar ideologicamente de diversas maneiras. Importante a distinção que os autores fazem entre a racionalidade neoliberal e as ideologias dominantes que adotam essa racionalidade. Dessa forma, posições nacionalistas e regionalistas, como o Brexit e a vitória de Trump nos EUA, que podem parecer, à primeira vista, um retrocesso do neoliberalismo, são, na verdade, mais um momento de reforço dessa lógica, mas com novas roupagens ideológicas.

60 - O novo capitalismo está profundamente ligado à construção política de uma finança global regida pelo princípio da concorrência generalizada. Nisso, a "mise en marché" (marketisation) da finança é filha da razão neoliberal. 
Em suma, esse processo de consolidação do neoliberalismo como lógica dominante nas sociedades contemporâneas tem raízes profundas na superação do Estado de bem estar social e se viabilizou, como bem demonstram Dardot e Laval (2010b), no processo de globalização e financeirização da economia mundial.

Em uma análise bastante anterior, Chesnais (1998) já demonstrava essa relação bastante próxima entre globalização e financeirização, postulando que "[...] a esfera financeira representa a ponta-de-lança da mundialização da economia" (CHESNAIS, 1998, p. 11) relacionando esses dois processos na definição do que chamou de "mundialização financeira" que "designa as estreitas interligações entre os sistemas monetários e os mercados financeiros nacionais, resultantes da liberalização e desregulamentação adotadas inicialmente pelos Estados Unidos e pelo Reino Unido, entre 1979 e 1987" (CHESNAIS, 1998, p. 12). Este processo de mundialização financeira teve sua origem, segundo $o$ autor:

[...] de um processo de interação, ao longo de uns quinze anos, entre o fortalecimento do capital privado - tanto industrial como bancário - e 0 crescente impasse das políticas governamentais. O contexto geral é o fim dos "anos dourados". Ou seja, embora ela tenha começado a se manifestar em fins da década de 60, a mundialização financeira não pode ser compreendida fora do que os regulacionistas chamaram de "crise do modo de regulação fordista". (CHESNAIS, 1998, p. 16)

No mesmo movimento da análise de Dardot e Laval (2010b) apresentada anteriormente acerca do processo pelo qual o neoliberalismo assume uma posição hegemônica enquanto forma de organização da sociedade contemporânea, com implicações em todas as esferas da vida humana, Chesnais (1998, p. 17) aponta para a importância da compreensão do contexto político e social que propiciaram terreno fértil para o processo de mundialização financeira.

O fracasso das políticas de reerguimento a partir da demanda, a estagflação dos fins da década de 70 e a determinação de romper as condições que ainda permitiam aos assalariados defender seu poder de compra e manter suas conquistas sociais, provocaram a guinada monetarista dirigida por Paul Volcker [...] e afinal desembocaram na "revolução 
conservadora" de Margaret Thatcher e Ronald Reagan. Mas essa guinada correspondeu também ao momento em que os fundos de pensão e as sociedades de aplicação coletiva de valores mobiliários (os pension funds e mutual funds anglosaxônicos), que são os atores principais do regime de finanças de mercado mundializado, ultrapassaram certo limiar no montante de poupança que centralizavam. (CHESNAIS, 1998, p. 17)

Portadores da racionalidade da "criação de valor acionário", os fundos de pensão e os fundos mútuos se tornam atores cada vez mais importantes, à medida que concentram montantes cada vez maiores de recursos numa lógica rentista de busca de oportunidades globais de valoração de capital. Valoração esta que tanto pode operar na esfera financeira (capitalização), atuando na alocação e apropriação de valor, quanto pode financiar, impondo sua lógica própria de funcionamento, investimentos produtivos na chamada economia real, mobilizadora de fatores de produção e, portanto, geradora de novos valores (valorização).

Devemos, aqui, evitar restringir-nos à leitura corrente de que a esfera financeira do processo de criação de valor teria se autonomizado em relação à esfera real, industrial. Por mais que ela tenha ganhando espaço e se tornado dominante, ela o é também pelo fato de que, na realidade, ela comanda (coordena) a alocação de capital fixo na produção industrial. Francisco de Oliveira nos lembra que, sem dúvida,

[...] existe uma acumulação comandada pelo capital-financeiro, ou uma acumulação à dominância financeira, como quer Chesnais, mas nunca no sentido estrito de que a valorização do capital deixa de passar pelo sistema produtivo. Ou dizendo de outra maneira: a forma financeira descolou-se da forma capital-produtivo, e a divisão mundial do trabalho é agora comandada pela oferta de capital-dinheiro, que escolhe as localizações espaciais do capital-produtivo. (OLIVEIRA, F., 2005, p. 34)

Para compreendermos como a escolha do capital-dinheiro acerca da alocação do capital-produtivo é feita numa economia financeirizada, precisamos entender como esse capital financeiro consegue se associar ao capital produtivo e, com ele, produzir valor, para além de sua função de criação de capital fictício. Na realidade, o fato de as grandes empresas industriais terem, elas também, passado por um processo de financeirização de seu 
processo de busca por rentabilidade, abrindo seus capitais em busca de financiamentos a baixo custo, gerou grandes oportunidades de investimentos para esses grandes fundos internacionais.

A presença dos grandes grupos multinacionais como membros ativos do sistema financeiro mundializado tem como contrapartida o fato de que eles próprios são cada vez mais considerados "ativos de rendimento" pelos fundos de pensão e de arbitragem [...] e outros "investidores institucionais", cujos representantes nos conselhos de direção têm os olhos pregados na distribuição trimestral de dividendos. (SERFATI, 1998, p. 143)

Lembrando que o "capital constitui uma relação social que permite se apropriar de uma parte do valor criado pelo processo de trabalho" (SERFATI, 1998 , p. 145), e que, uma vez posto em movimento a partir destes grandes fundos,

parece se desdobrar: ao lado do capital existente sob a forma de equipamentos produtivos, que servem de fundamento ao processo de trabalho, existe uma outra forma de capital, composta de direitos de propriedade e créditos, que certifica o direito de seus detentores a uma participação no valor criado. (SERFATI, 1998, p. 145)

Desta forma, seria justamente essa "outra forma de capital", garantidora de direitos de propriedade que garantiria, também, a apropriação de parte do valor produzido pelo trabalho. Mesmo que fictício, sua relação com a produção e apropriação de mais-valia estaria garantida por esses direitos de propriedade. Por mais fictício que possa parecer, Serfati (1998) nos lembra que o valor que se apropria por meio desses fundos tem sua origem na produção da mais-valia, na economia real, caracterizando, na realidade, um processo de centralização de capital (nas mãos dos fundos de investimento) que, ao capitalizar os recursos, o faz tendo como perspectiva, também, a valorização do capital pelo trabalho.

A frutificação desse capital-dinheiro - sob a forma de dividendos, de juros e de variáveis "híbridas" de rendimento se baseia, no fim das contas, no valor criado na esfera da produção de bens. Atualmente, a "tirania dos mercados" não significa nada mais que o direito dos que centralizam esse capital-dinheiro, depois de o terem criado e multiplicado, de 
arrogar para si uma parte desmesurada das riquezas criadas no processo de produção. (SERFATI, 1998, p. 145-146)

Como isso funciona?

Esse fenômeno evidencia-se de forma mais acentuada quando os investidores institucionais - e, em primeiro lugar, os mutual funds e os pension funds - figuram, como é cada vez mais o caso, entre os acionistas mais significativos dos grupos, porque o encurtamento do tempo de retorno e a lógica do "curtoprazismo" se impõem como uma exigência suplementar. A dimensão industrial dos grupos pouco importa; ela não passa de direito de propriedade que eles se esforçam em valorizar o mais rápido possível. (SERFATI, 1998, p. 175-176)

Portanto, junto com a globalização e a financeirização, este elemento deve ser destacado. Os fundos de investimento são um dos elos entre essas duas dimensões da sociedade neoliberal, ao operarem, fortemente e rapidamente, a transferência patrimonial destes direitos de propriedade e, com isso, coordenarem os fluxos internacionais de capitais. Importante retermos que

[...] o poder crescente dos investidores institucionais constitui uma inovação maior nas relações entre indústria e finanças. (SERFATI, 1998, p. 177)

Pessanha (2019) nos traz uma excelente compreensão acerca do papel destes fundos financeiros no capitalismo contemporâneo, financeirizado e neoliberal, ao analisar as condições que tornaram possível que o rentismo avançasse sobre a esfera da produção de valor a níveis nunca antes imaginados. Em um processo de "Espoliação da força de trabalho e a transferência de valor da produção para a financeirização" (2019, p. 40), esses fundos direcionam "o dinheiro que tinha origem na produção e posterior circulação das mercadorias [...] para os juros e para o rentismo", transformando renda em capital fictício.

A transformação dessas rendas em capital fictício ganhou agilidade e volume, encontrou nos fundos financeiros uma plataforma superior e mais eficiente para se movimentar, reproduzir e acumular ativos do que os antigos conglomerados bancários. Os fundos financeiros assim se tornaram o locus ideal, onde ampliam o seu potencial de acúmulo e usufruem da mobilidade tão desejada pelo capital para fugir das crises 
sistêmicas, através da migração para outras ações e espaços para a sua reprodução. $(2019$, p. 40)

Esta agilidade temporal (na velocidade com que investem ou desinvestem) e espacial (ampliando alternativas ao desconsiderar as distâncias) que os fundos proporcionam ao capital está na base tanto das novas configurações espaciais da produção quanto dos riscos de instabilidade associados a essa grande agilidade de escolhas de investimento.

É cada vez mais importante que consigamos compreender a relação existente entre esses dois processos de geração de capital. O rentista, associado a um processo de capitalização, criador de capital fictício, e o processo de valorização, que surge diretamente do processo produtivo.

A maior parte das análises sobre o capitalismo dentro do sistema mundo ainda separa o rentismo da produção material como se tratassem de coisas diferentes. (SERFATI, 1998, p. 41)

$\mathrm{Na}$ realidade, a financeirização da economia opera uma imbrincada relação entre esses dois momentos, que jamais são estanques, não são dissociados, e, mais do que isso, ao se compreender o funcionamento dos fundos de investimento conseguimos compreender como que ambos processos são mutuamente dependentes na economia contemporânea.

Os fundos foram aumentando, ao mesmo tempo, a sua mobilidade e a sua concentração, com mais produtividade para o empreendedor e maior rentabilidade para o investidor. Para isso, eles se mostraram uma ferramenta com enorme mobilidade e agilidade para a produção de movimentos verticais e horizontais. Verticais de formação de valor e horizontais com a escolha das frações do capital com maior lucratividade em diferentes espaços. Os fundos de investimento apresentam-se, além disso, como poderoso instrumento de integração entre o rentismo e a acumulação sistêmica. (PESSANHA, 2019, p. 85)

Aqui é importante evidenciarmos que essa agenda de pesquisa se desdobra em, pelo menos, duas frentes: uma primeira, e a mais corrente e aprofundada, que se refere ao papel da financeirização no desenvolvimento do mercado imobiliário urbano, sobretudo das grandes cidades, onde a financeirização opera o duplo movimento de financiamento da produção 
imobiliária, mercantilizando a produção habitacional, por exemplo, simultaneamente ao processo especulativo acerca dos preços imobiliários urbanos por meio de criação de monopólios temporários de produtos diferenciados capazes de capturarem mais valia produzida em outras esferas. Esta frente se dedica, sobretudo, a buscar entender como é que, a partir do processo de concentração urbana de capital, em projetos imobiliários específicos, é possível produzir valor (ou anti-valor) a partir do processo de capitalização, baseado na especulação imobiliária e no recebimento de juros sobre adiantamento de capital-dinheiro.

Uma segunda frente busca compreender como esses fundos coordenam a alocação de capital fixo no espaço, permitindo o processo de centralização de capital, seja ele local ou global. Especificamente para o que aqui nos é importante, o autor chama a atenção à potência que esses fundos adquiriram na capacidade de comandar capital fixo.

Os fundos financeiros demonstraram oferecer maior capacidade ao capital, para se enraizar como capital fixo implantando em projetos no território. Depois, possuem menos dificuldades que as corporações para se desenraizar. A sua valorização através dos produtos e dos serviços transformam em dinheiro (lucros) e voltam a condição de capital. No circuito do valor, em determinado momento do CSA (ARRIGHI, 1997), - capital necessita se territorializar para produzir valor. O capital precisa se embutir (to embed) no território, nas instituições locais/comunidade e se articular com as partes que possuem interesses nos seus negócios. (PESSANHA, 2019, p. 188)

Associando essa característica dos fundos de investimentos com o processo descrito anteriormente de financeirização dos grupos industriais, que se lançaram aos mercados de capitais para financiarem suas atividades e investimentos, encontramos a conjunção perfeita entre a necessidade de recursos para expansão de atividades e a busca constante por remuneração e rentabilidade.

Os fundos financeiros possuem maior agilidade para se movimentar como investimentos entre as frações do capital e investimentos em diferentes setores da economia. $O$ setor econômico e o espaço interferem na rentabilidade dos empreendimentos. Assim, é fato que os fundos são mais ágeis 
que uma corporação para sair de um negócio e entrar em outro numa ou noutra região. (PESSANHA, 2019, p. 189)

Importante lembrar também que uma parte significativa desses fundos de investimentos internacionais são fundos de pensão. Como fundos de pensão, concentram a poupança individual de milhões de pessoas que buscam na rentabilidade deles a proteção para a falta de renda futura (na velhice) que 0 Estado não Ihes proporciona. Talvez seja justamente na conjunção desses fundos de pensão com a participação deles em projetos produtivos ao redor do mundo que encontramos uma das expressões extremas e mais acabadas da extensão da penetração da racionalidade neoliberal em que vivemos. Devido à ausência de proteção estatal, seja porque ela nunca chegou a existir, seja porque foi desmantelada, pequenas poupanças individuais são alocadas em grandes fundos de investimentos que buscam por oportunidades de baixo risco (não majoritariamente especulativo-financeira, portanto) capazes de garantir um fluxo futuro de rendimento, geralmente na base de dividendos. Dessa forma, indivíduos que passam a "consumir" alternativas concorrenciais de alocação de seus recursos para suprir uma necessidade que outrora fora considerada dever do Estado (aposentadoria), passam a ter a "liberdade" de melhor alocar seus recursos e, para isso, "consomem" no mercado da "indústria de fundos" as melhores alternativas.

Esses fundos, por sua vez, fazem o mesmo com a escolha de alternativas de investimento produtivo, via participação acionária, colocando projetos e empreendimentos específicos também em concorrência entre si, o que, consequentemente, coloca diferentes lugares também em concorrência uns com os outros como melhores alternativas de investimento. Portanto, essa lógica demonstra como a financeirização, por meio dos fundos de investimento, para além de funcionar como competição e especulação do grande capital (processo extremamente importante e exaustivamente estudado), conecta pessoas, empresas e lugares numa lógica concorrencial em busca de oportunidades, incorporando por completo a racionalidade neoliberal da liberdade individual e da concorrência generalizada.

Como veremos mais adiante, justamente por compreender que esse processo é fundamental para entendermos o desenvolvimento urbano de 
regiões distantes dos grandes centros, mas sob influência de grandes empreendimentos financeirizados globalmente, é que o estudaremos para o exemplo de Itaituba, no baixo Tapajós. E veremos também que, diferentemente da importância que tem para a primeira frente indicada acima a renda da terra, enquanto elemento de coordenação de alocação de capital fixo no processo ampliado de acumulação de capital, tem uma importância crucial para conseguirmos explicar o desenvolvimento recente dessa região.

Nesse movimento descrito até agora de tomada de hegemonia da racionalidade neoliberal, processo, como vimos, concomitante ao aprofundamento dos processos de financeirização e globalização das economias nacionais, quando se consolidam conexões entre as grandes cidades mundiais na chamada economia de arquipélogo, grandes transformações vêm ocorrendo tanto no desenvolvimento dessas grandes cidades quando nas características do processo de formação regional.

\subsubsection{Os reflexos na centralidade dos lugares}

Em um primeiro momento, o que parece estar acontecendo vem da constatação de que as hierarquias entre as cidades estão se alterando, como apontado por Ciccolella e Mignaqui (2008), “La globalización de la economía ha alterado las jerarquías urbanas vigentes hasta principios de los años ochenta y ha producido un re-escalamiento de las estructuras espaciales al interior de cada país" ${ }^{61}$ No entanto, vale notar que, além de o tal reescalonamento não ter se operado apenas no interior de cada país, mas sim numa escala global, é a própria noção de hierarquia que passa a estar em questão. Lembrando que o que ordena o posicionamento das cidades (de todos os tamanhos e tipos) nessa hierarquia é o grau de sua centralidade, como visto anteriormente, os autores reconhecem e indicam que a própria noção de centralidade, definidora dessas hierarquias, foi impactada.

Los cambios tecnológicos y la revolución en las tecnologías de la información y comunicación han permitido al capital global circular con mayor fluidez, modificando no solo el concepto de distancia, tal como era concebido por la teoría de la

61 - A globalização da economia alterou as hierarquias urbanas vigentes até princípios dos anos oitenta e produziu um reescalonamento das estruturas espaciais no interior de cada país. 
planificación clásica (años cincuenta y sesenta del siglo pasado), sino también el concepto de espacio-tiempo. La reconfiguración territorial a partir de entonces y el uso de la telemática han impactado sobre la centralidad urbana, en particular sobre la localización de los espacios de comando y servicios avanzados sobre los que opera la economía mundial. (CICCOLELLA; MIGNAQUI, 2008) ${ }^{62}$

Portanto, se os estudos regionais e urbanos até fins do século $X X$ se concentravam em compreender a estruturação da centralidade dos lugares, sua história e suas características, comparando-os e hierarquizando-os, no momento em que essa centralidade se altera, é necessário compreendermos que alteração foi essa e como ela impacta a própria noção de hierarquia e da própria urbanização.

Historicamente, assistimos à constituição da centralidade urbana industrial na passagem, primeiro, da economia agrário-comercial para a centralidade urbano-industrial. Como vimos, essa definição pode ser matizada a partir da noção de uma centralidade urbano-industrial liberal e uma centralidade urbano-industrial fordista, esta última formadora das metrópoles do final do século XX. Ambas marcaram suas eras e possuem corpos teóricos distintos que explicam seu funcionamento.

Desta forma, recuperando as teorias estudadas anteriormente, é possível dizer que a centralidade liberal poderia ser definida pela importância do lugar para a produção e para a concorrência capitalista. Por sua vez, a centralidade fordista releva da importância do local para a produção e consumo de massa e, simultaneamente, para a centralização de capital (definindo o locus do oligopólio), formador de metrópoles.

Como poderíamos compreender a essência da centralidade no momento neoliberal do capitalismo contemporâneo?

62 - As mudanças tecnológicas e a revolução nas tecnologias da informação e da comunicação permitiram ao capital global circular com maior fluidez, modificando não só o conceito de distância, tal como era concebido pela teoria da planificação clássica (anos cinquenta e sessenta do século passado), mas também o conceito de espaço-tempo. A reconfiguração territorial a partir de então e o uso da telemática impactaram sobre a centralidade urbana, em particular sobre a localização dos espaços de comando e serviços avançados sobre os que opera a economia mundial. 


\subsubsection{A centralidade na era metropolitano-neoliberal}

Postula-se aqui, a partir da mudança do mundo fordista para o neoliberal (e não apenas industrial para o financeiro), com um grande paralelo à proposição de (LEOPOLDO, 2016, p. 2) de que "the world has moved from an urban-industrial economy to a metropolitan-financial economy, establishing a new era"63, de que estamos presenciando a era metropolitano-neoliberal na sociedade, e não apenas no âmbito econômico, com a consolidação de uma centralidade metropolitano-neoliberal que organiza a formação do espaço contemporâneo.

Se, na visão do autor, a passagem da economia agrário-comercial para a urbano-industrial já foi bastante estudada (apesar de algumas divergências, como o postulado por Jacobs) e seu entendimento é bastante consolidado, "the transition from the urban-industrial economy to a new time, the metropolitanfinancial economy, has not deserved a more detailed treatment." (LEOPOLDO, 2016, p. 3) ${ }^{64}$

$\mathrm{Na}$ proposição de Leopoldo (2016, p. 4) essa nova era tem sua historicidade, definida como novas estratégias no processo de acumulação de capital, necessárias devido ao esgotamento do modelo fordista e possibilitadas pela consolidação do neoliberalismo:

The transition from the predominance of the urban-industrial economy to the metropolitan-financial economy is limited to the period between the concrete emergence of the metropolitan capitalist space in the USA in the middle of last century to the metropolitan deconcentration policies in the peripheral countries in the 1970s and 1980s. Deregulation of the financial sphere and neoliberal policies mobilized new strategies of capital by way of the metropolization of space..$^{65}$

63 - [...] o mundo moveu-se de uma economia urbano-industrial para uma economia metropolitanofinanceira, estabelecendo uma nova era.

64 - [...] a transição de uma economia urbano-industrial para um novo tempo, a economia metropolitanofinanceira, não careceu de um tratamento mais detalhado. Não há um entendimento mais compreensivo dos termos do que estamos chamando de economia metropolitano-financeira"

65 - A transição da predominância da economia urbano-industrial para a economia metropolitanofinanceira é limitada ao período entre a emergência concreta do espaço metropolitano capitalista nos Estados Unidos na metade do último século à desconcentração metropolitana das políticas nos países periféricos nos anos 1970 e 1980. A desregulação da esfera financeira e as políticas neoliberais movilizaram nova estratégias do capital por meio da metropolização do espaço. 
Ela se constitui também como uma nova dialética (e por isso a noção de ruptura) no processo de produção de valor na sociedade contemporânea onde, como vimos, a literatura costuma mostrar o predomínio das finanças na geração de valor contemporâneo.

A época metropolitano-financeira é o momento mais contemporâneo e determinado do capitalismo, onde operam profundas metamorfoses que apontam para uma nova dialética da produção do espaço. Nesse movimento, a produção da riqueza mundial se articula muito mais à esfera financeira que a produção propriamente dita. (LEOPOLDO, 2018, p. 95)

A definição dada por Leopoldo (2016) acerca dessa nova era, a metropolitano-financeira, opta por basear-se no deslocamento que o processo de financeirização promoveu na relevância do processo de produção de valor na economia capitalista. Portanto, apesar de uma nova era, seja na produção industrial, seja na produção financeira, o que rege a noção de centralidade, em ambas as eras, é a importância do lugar (da cidade) como locus de produção. Enquanto locus de produção, a ênfase é posta na compreensão seja na fase de produção de mais-valia, por meio do comando da força de trabalho, seja na fase de realização da mais-valia, quando essa se realiza no mercado enquanto lucro, seja ele especulativo, fictício ou não.

Portanto, a nova dialética da produção do espaço é também uma nova lógica de produção do valor. No limite, se, talvez, o capital gerado na esfera financeira não seja tão fictício assim, ao contrário do que a tradição dos estudos marxistas está inclinada a aceitar, a despeito do próprio Karl Marx que previu a insubordinação e hegemonia do capital financeiro [...] É nesse compasso de financeirização da economia simultânea ao processo de metropolização, corroborando com a difusão do metropolitano, produção de regiões e espraiamento das formas imobiliárias metropolitanas por toda parte, que há a constituição de uma nova lógica de produção do espaço, condição e meio da nova lógica econômica. Desse modo, a época metropolitano-financeira é a própria supremacia da simultaneidade entre a produção do metropolitano e o predomínio das finanças, que chega no século XXI em seu período mais avançado, apesar de sua emergência bem anterior na década de 1970. (LEOPOLDO, 2018, p. 95-96)

De certa maneira, quando compreendemos o metropolitano como resultante do fordismo e não necessariamente apenas do industrial (daí a importância de separar o momento liberal do momento fordista) e, enquanto 
fordista, entendido como resultante da produção e do consumo em larga escala, poderíamos dizer que a produção financeira de valor também poderia ser entendida como fordista, porque, se entendermos a própria finança como uma indústria, ou seja, como um processo de mobilização de fatores de produção em grande escala, capaz de mobilizar grandes quantidades de força de trabalho para dela extrair mais-valia, a própria finança estaria seguindo regras fordistas de produção. $O$ fato de parte significativa do valor financeiro na realidade ser fictício e especulativo não contradiz essa afirmação, apenas chama a atenção a que essa mercadoria, a financeira, por diversas razões, é mais propícia à geração de valores fictícios. No entanto, o princípio fordista da produção de valor em larga escala, por mais paradoxal que possa parecer, não deve ser esquecido.

Esta visão acerca da relevância dos processos de produção de valor, seja na era industrial, seja na era financeira, fica ainda mais evidente quando Leopoldo (2018, p. 96) escolhe seu objeto empírico de análise, ou seja, os empreendimentos Alphaville. $\mathrm{O}$ autor os define como "produto imobiliário que representa no território nacional a transição do urbano ao metropolitano". Ele de fato o é e a análise do autor é precisa. No entanto, entendemos, pelo que foi posto acima, que esse produto imobiliário representa o que há de mais urbano no metropolitano, ao focar no que há de mais "industrial" nas finanças, a produção imediata do espaço urbano, por mais financeirizada que possa estar, como de fato está e o autor muito bem demonstra.

Nossa proposição aqui é outra, se bem que complementar e relacionada a esta. Se, para a compreensão das mudanças estruturais pelas quais as metrópoles mundiais passaram no final do século $X X$, e pelas quais continuam passando, devido a essa mudança de era, é extremamente relevante entendermos a relação entre o processo de produção de valor nas finanças e as novas espacialidades, dado que essas metrópoles são, justamente, o locus da financeirização. Para a compreensão das transformações em regiões e cidades desprovidas de mercados financeiros relevantes, como é o caso do baixo Tapajós, a compreensão só é possível a partir do entendimento do processo global de acumulação de capital que engloba, além da produção de valor, sua distribuição. 
Portanto, nossa proposição de uma transição de um mundo urbanofordista para um mundo metropolitano-neoliberal busca abarcar todas as esferas no processo global de acumulação de capital, enfatizando uma ruptura explicativa não entre duas formas de produção de valor, mas sim entre dois momentos da acumulação global, a produção e a distribuição de valor.

Ambas as definições fazem referência ao mesmo processo, o da superação do mundo fordista pelo mundo neoliberal, cuja transição mostramos anteriormente. No entanto, a adoção de uma ou de outra enfatiza aspectos distintos do mesmo macro-processo, sem negar os demais aspectos, da mesma forma que a ênfase na produção do espaço metropolitano não nega a produção dos espaços regionais, mesmo que distantes. A única diferença é que entendemos que a segunda abordagem nos permite compreender como antigas hierarquias são substituídas por outras relações de centralidade e não apenas como uma alteração de posição em uma hierarquia de cidades mais ou menos metropolizadas.

Resumidamente, ao estudarmos uma metrópole, como São Paulo, por exemplo, é extremamente importante compreendermos como sua centralidade industrial passou para uma centralidade de prestação de serviços e, sobretudo, serviços financeiros. Seria a passagem da era urbano-industrial para o metropolitano-financeiro. No entanto, para estudarmos um espaço não metropolitano, como é o baixo Tapajós, vimos que teorias baseadas na noção de centralidade do tipo crhistaleriana ainda são bastante relevantes para compreendermos como ela se estrutura na hierarquia de cidades da região. No entanto, para entendermos novas formas de estruturação do espaço regional do baixo Tapajós no século XXI, necessitamos compreender como que essa região se conecta aos grandes fluxos de capitais mundiais, definindo qual sua função no desenvolvimento do capitalismo metropolitano-neoliberal, bem mais amplo do que apenas o aspecto da financeirização. É o que faremos no item 2.4 desta Parte 2. No momento, reconhecendo o fato da grande concentração e conexão das grandes metrópoles mundiais, iremos compreender como diferentes correntes teóricas buscaram explicar os fenômenos urbanos contemporâneos. 
Do ponto de vista das macro-tendências do processo de urbanização, essas reconfigurações territoriais, a partir do metropolitano, têm levado ao seguinte movimento:

Cities are merging together to create urban settlements on a massive scale. These configurations take the form of megaregions, urban corridors and city-regions. They are emerging in various parts of the world, turning into spatial units that are territorially and functionally bound by economic, political, sociocultural, and ecological systems. Cities in clusters, corridors and regions are becoming the new engines of both global and regional economies, and they reflect the emerging links between urban expansion and new patterns of economic activity. ${ }^{66}$ (UNITED NATIONS HUMAN SETTLEMENTS PROGRAMME, 2010, p. IX)

\subsection{A estruturação do espaço regional e urbano no pós-fordismo}

Do mesmo modo que fizemos na Parte 1 desta tese, aqui vamos apresentar um conjunto de literaturas teóricas que buscaram, cada uma à sua maneira, compreender o impacto da passagem do mundo urbano-fordista para o metropolitano-neoliberal (sem, evidentemente, utilizarem essa terminologia). Desta forma, menos do que contrastá-las, pretendemos indicar no que cada uma delas pode contribuir para a compreensão das lógicas espaciais deste novo momento do capitalismo.

Outro objetivo desta apresentação dessas teorias é indicar possíveis pontos de diálogo entre essas diferentes teorizações que, em um momento ou outro, acabam por se complementar, teórica ou empiricamente, na tentativa de apreensão do fenômeno urbano.

Grosso modo, nesta nova era pós-fordista e neoliberal, podemos apontar de forma bastante abrangente, e não desconsiderando a grande diferenciação entre as teorias agrupadas, três importantes grupos teóricos. A Nova Geografia Econômica, a Especialização Flexível e um conjunto de

66 - Cidades estão emergindo juntas para criar estabelecimentos urbanos em escala maciça. Essas configurações tomam a forma de mega-regiões, corredores urbanos e cidades-regiões. Elas estão emergindo em várias partes do mundo, tornando-se unidades espaciais que são territorialmente e funcionalmente ligadas por sistemas econômicos, políticos, sócioculturais e ecológicos. As cidades são feixes, corredores e regiões que se estão tornando as novas máquinas tanto das economias globais quanto das regionais e elas refletem as ligações emergentes entre a expansão urbana e novos padrões de atividade econômica. 
abordagens que se dedicaram a estudar especificamente as Grandes Cidade Mundiais.

\title{
2.2.1 A Nova Geografia Econômica
}

No primeiro grupo, em um importante esforço de integração e atualização das teorias clássicas de localização e as teorias de desenvolvimento regional, temos a Nova Geografia Econômica (NEG), inaugurada por (KRUGMAN, 1991) que, segundo (THISSE, 2011, p. 18),

\begin{abstract}
destacou a sustentação microeconômica das aglomerações econômicas espaciais e os desequilíbrios regionais nos níveis nacional e internacional", tendo, para isso, construído "um modelo completo de equilíbrio geral, capaz de explicar por quê, como e quando a atividade econômica pode ser concentrada em poucos locais.
\end{abstract}

Sua perspectiva busca dar conta de incorporar um princípio de competição monopolística (DIXIT; STIGLITZ, 1977), em contrapartida ao modelo de concorrência perfeita e os processos cumulativos apontados por Myrdal (1960). Desta feita, como apontado por Thisse (2011, p. 34), "é lícito dizer que Krugman apresentou uma síntese da polarização e as teorias neoclássicas padrão", em um esforço de atualizar-se, simultaneamente, às lógicas do mundo fordista de produção, deixando para trás, com um grande atraso, as teorias de inspiração liberal.

A crítica feita pela NEG é a de que as teorias anteriores (tanto urbana quanto regional) não apresentavam uma teoria geral que explicasse a micro organização espacial dos agentes. Com isso, esta corrente propõe uma "teoria geral da economia no espaço", que, na realidade, formaliza o modelo centroperiferia que o aparato teórico ortodoxo não conseguia compreender até aquele momento. Desta forma, pode ser entendido como uma aplicação dos modelos de concorrência imperfeita, originalmente aplicados nas teorias de comércio internacional, nas teorias de economia regional (e, posteriormente, economia urbana). Tal modelo se encontra no livro Economia Espacial (The Spatial Economy, (1999)), escrito por Paul Krugman, Masahita Fujita e Anthony Venables, principais representantes dessa corrente. A obra resgata, por meio dos modelos de retornos crescentes, a economia regional na teoria econômica, 
sendo Krugman (1991) o primeiro a elaborar o modelo, que serviu de base para os modelos subsequentes.

De acordo com a sistematização de Ruiz (2006), o modelo centroperiferia da NEG tem

dois conjuntos de regras: o primeiro define como os consumidores alocam a renda (curva de demanda), e o segundo especifica como as firmas determinam o nível de produção e preços (curva de oferta). No caso da economia regional, as firmas e os consumidores distribuem-se entre as regiões e arcam com custos de transportes. Ambos tentam maximizar rendas e minimizar gastos tomando em consideração a localização dos demais agentes, ou seja, procuram otimizar sua localização na rede de economias regionais. Como nos convencionais modelos de equilíbrio geral, no modelo centro-periferia ofertas e demandas são determinadas simultaneamente. (RUIZ, 2006, p. 144-145)

Ao criticar o modelo de Von Thünen, a NEG assume as estruturas urbano-industriais de Christaller e Lösch como a aproximação mais realista possível às complexidades que se colocam na dinâmica socioeconômica. Complementarmente, os autores da NEG incorporam um número maior de indústrias (saindo do padrão simplista de apenas uma), com diferentes tecnologias e demanda. A partir dessas diferenciações, a NEG passa a conseguir modelar o fato de as cidades apresentarem diferentes estruturas de oferta, que se articulam por um comércio interregional, intra-industrial e intersetorial, e que acabam por estabelecer dinâmicas temporais distintas, diferenciando o território. (FUJITA; KRUGMAN; VENABLES, 1999)

De acordo com Duranton e Puga (2000), essa incorporação da teoria do lugar central de Thünen em um modelo de equilíbrio geral com fundamentos microeconômicos é bastante inovadora e um grande avanço para a Economia Regional. Entretanto, o modelo apresenta limitações empíricas, assim como algumas falhas ${ }^{67}$ identificadas pelos críticos da NEG e sistematizadas por Ruiz (2006), como: i) do lado da oferta não há nenhuma independência estratégica entre firmas; ii) a formação de preços se assemelha ao comportamento de empresas em setores competitivos; iii) as firmas são totalmente móveis;

67 - Os próprios autores reconhecem que o modelo centro-periferia não consegue gerar robustez nas distribuições de Pareto. 
portanto, não há custos irrecuperáveis; iv) os custos de transporte são um questionável modo de lidar com sistema de transporte; v) o modelo é estático, visto que sua dinâmica está completamente concentrada em um ajuste adaptativo do mercado de trabalho; vi) emprego, renda, preços e produção são definidos; e vii) a lei de Say é parte integrante do modelo, isto é, as firmas e os consumidores gastam toda a renda, logo não existe poupança, restrições e desemprego ${ }^{68}$.

Consideradas as críticas quanto ao modelo, faltava ainda à Nova Geografia Econômica incorporar o fator "crescimento econômico" em sua análise, o que é feito posteriormente com a chamada "síntese crescimentoaglomeração". De acordo com Baumont e Huriot (1999), essa síntese é feita integrando, por um lado, as teorias de crescimento endógeno, com seus princípios de acumulação temporal da atividade econômica; e por outro lado a NEG, que oferece os princípios da aglomeração espacial dessa atividade. Desta forma, a síntese crescimento-aglomeração procura explicitar os mecanismos de interações entre esses dois processos que até então eram analisados separadamente. Como resultante, passa a ser possível compreender, em uma única abordagem, o processo temporal de aglomeração e o processo espacial de crescimento. A título de exemplo, destacamos abaixo a estrutura básica dos modelos fundadores dessa abordagem, para indicar que ela é bastante flexível em termos de pressupostos de acordo com a realidade com a qual se gostaria de trabalhar. Diferenciam-se, sobretudo, nos processos de inovação e a natureza das externalidades (se local ou global):

1. Engelmann e Walz (1995): com quatro setores - bens tradicionais, bens industriais, bens intermediários diferenciados e P\&D - na qual a produtividade do setor industrial, que trabalha com os rendimentos

68 - Outras críticas sobre o modelo são inerentes aos próprios pressupostos microeconômicos, como, por exemplo, as firmas serem agentes passivos e homogêneos e todos os insumos e ativos serem idênticos, tornando as empresas simétricas. "Em tal ambiente, os produtores observam somente a demanda e investem sem qualquer constrangimento financeiro, tecnológico ou informacional. Elimina-se, assim, a existência de ativos específicos capazes de criar assimetrias econômicas entre produtores, tais como efeitos de transbordamentos regionais (spillovers) e/ou localizados e ativos intangíveis. Também não estão presentes processos de imitação e seleção. Por tudo isto, produtos não são excluídos do mercado, as firmas não falem e não existe nenhuma perda de capital. Além disso, a simétrica preferência por variedades, que é a base teórica do comportamento do consumidor, é uma hipótese questionável, em particular quando empregada na formulação de modelos industriais (equilíbrio parcial). Em resumo, o modelo microeconômico de referência é frágil e as 'micro-diversidades' são restritas". 
crescentes, aumenta com a variedade de bens intermediários. Há imobilidade de bens diferenciados, produção de bens indiferenciados e mão de obra não qualificada.

2. Walz (1996): com a mesma estrutura setorial, mas com mobilidade, a partir de um custo, de bens diferenciados, mas imobilidade do trabalho não qualificado e de estruturas locais e da produção de bens indiferenciados.

3. Martin e Ottaviano (1999): com três setores - bens indiferenciados, bens diferenciados e P\&D. Também com mobilidade de bens diferenciados e imobilidade de bens indiferenciados, mas com uma imobilidade espacial (não setorial) de trabalhadores.

\subsubsection{Especialização Flexível}

Um segundo grupo teórico (caracterizado como sendo um conjunto de literatura de fato pós-fordista, os estudos que partem da superação do fordismo pela especialização flexíve), recorre à compreensão do processo industrial fundado na inovação tecnológica e novas formas de organização da produção. Desta forma, os principais teóricos dessa linhagem partem dos distritos marshallianos e incorporam a herança neoschumpeteriana acerca da importância dos processos de inovação. (MATTEO, 2011)

Com a superação do fordismo, caracterizado pela queda tanto da produtividade quanto da relação capital/produto, uma nova forma de organização industrial se impõe, geralmente como idealização de casos bem sucedidos mundo afora. Para além da discussão das causas da crise do fordismo (se é uma crise de demanda, logo, de subconsumo, ou de oferta, insuficiência de rentabilidade), o fato é, como apontam Lipietz e Leborne (1994) e Matteo (2011), a crise deve ser entendida a partir da compreensão de duas causas. Uma delas por questões internas, decorrente do próprio modelo de desenvolvimento; e a outra externa, devido à internacionalização da economia. Deste modo, a flexibilidade nos processos produtivos surge como uma adaptação a essas causas que se agravam a partir do final dos anos 1960 .

No campo da organização industrial neste novo tempo, a especialização flexível se compõe de um "sistema em pequenas empresas altamente inovadoras, participantes de um mercado global de produtos de alta qualidade 
e com a produção orientada ao atendimento de uma demanda cada vez mais exigente e volúvel". Com isso, ela acarreta a formação de distritos industriais de alta tecnologia, voltados tanto ao mercado interno, quanto ao consumo diversificado e customizado. Como sua estrutura é constituída de pequenas empresas, estas estariam desvinculadas da hierarquização característica das metrópoles fordistas (MATTEO, 2011, p. 83-84) e trariam outras formas de organização espacial da produção.

O fundamento teórico dessa vertente, cujos autores principais são Piore e Sabel (1984), é estabelecido "quando os mercados de massa tornam-se estagnados e a competição intensifica-se, as firmas procuram diversificar seus produtos para atrair consumidores" (1984, p. 86). As que conseguem se adaptar são aquelas que apresentam tecnologias flexíveis, aumentando, assim, sua eficiência. A revolução informacional e das tecnologias de comunicação também é fator que facilita e favorece esses novos sistemas flexíveis de produção. Ao mesmo tempo, esse ambiente se torna competitivo, estimulando os avanços tecnológicos.

Do ponto de vista da regulação microeconômica, uma mudança da produção em massa para a especialização flexível permite um tipo de economia regulada por preços de mercado, seja por causa do aumento do número de pequenas empresas, seja pela disponibilidade livre dos recursos. Além disso, com as mudanças na demanda, as firmas poderiam simplesmente usar a capacidade flexível de suas máquinas para fabricar as mercadorias cujos preços estivessem em alta. Em outros termos, a demanda ditaria os preços a serem pagos, e às firmas caberia programar-se adequadamente para produzir, tendo em sua estrutura de custos este preço. (MATTEO, 2011, p. 86)

Como enunciado acima, um dos grupos teóricos da especialização flexível é o baseado nos distritos industriais à la Marshall, onde se constituem as chamadas regiões de produção flexível. Por exemplo, são regiões da Itália centro-setentrional (a chamada Terceira Itália), ou as confecções novaiorquinas.

Esses distritos são compostos por empresas de pequeno porte e com tamanhos semelhantes em uma complexa rede de cooperação e concorrência. 
Esse ambiente faz com que esses distritos estejam em constante reorganização de seus recursos humanos. (MATTEO, 2011)

Ao mesmo tempo se cria um intercâmbio entre atividades ou entre empresas, estabelecendo-se o que Marshall definiu como um "ambiente industrial", em que há transmissão de conhecimentos tanto de forma tradicional como interpessoal e informal. Outro fator essencial que Becatini (1994, p. 43) destaca na formação desses distritos é a existência de bancos locais para o acesso ao crédito. Portanto, o autor destaca que a concentração dessas empresas não é acidental, e que cada aglomerado apresenta suas especificidades. As "empresas estão arraigadas no território e não é possível conceber esse fenômeno sem ter em conta a sua evolução histórica".

A partir da compreensão das premissas destes diferentes aportes teóricos, evidencia-se que a forma de organização do território se altera, "tendo em vista que a hierarquia urbana fundada desde a primeira Revolução Industrial e consolidada no fordismo não é mais um elemento fundamental para o desenvolvimento econômico." É estabelecida uma competição entre regiões, ou mesmo entre cidades no processo de adequação deste novo modelo de desenvolvimento. (MATTEO, 2011, p. 89)

Competição essa que, vale lembrar, é um dos pilares do neoliberalismo.

Desse conjunto de literaturas apresentadas até aqui é importante ressaltarmos duas coisas:

- Fica patente que a NEG demorou um pouco a reagir frente às transformações ocorridas no século XX. Buscando dialogar com a literatura que já se delineava para compreender a superação do fordismo (as vertentes ligadas à especialização flexível), a NEG acaba por contribuir, sobremaneira, para incorporar ao mainstream econômico os resultados teóricos da vertente keynesiana de Myrdal e Hirschman ao conseguirem modelar o modelo centro-periferia, tão importante para compreendermos a formação das grandes metrópoles mundiais, justamente quando elas começam a dar sinais de profundas transformações. 
- Por outro lado, a literatura de especialização flexível, ao enfocar os processos produtivos associados à superação do fordismo, dá ênfase desmesurada para os setores modernos da economia, dinâmicos ("as regiões que ganham"), esquecendo-se de compreender as permanências, as importantes heranças presentes nessas grandes cidades que, apesar de não serem mais o locus preferencial da especialização flexível, continuam a mostrar importância.

Para compreendermos a importância dessas grandes cidades, iremos verificar, primeiro, como a Economia vem estudando as cidades nas últimas décadas para, então, discutirmos as principais correntes que se dedicaram a estudar especificamente as Grandes Cidades Mundiais.

\subsubsection{Estudos Urbanos: uma perspectiva da Economia}

Podemos encontrar em Derycke (2009) um balanço dos últimos 40 anos da pesquisa francesa em Economia Urbana. De acordo com sua classificação, os estudos contemporâneos pós-1995 podem ser classificados em seis grupos:

1. Nova Economia Urbana : com todos os trabalhos herdeiros da Nova Geografia Econômica decorrentes da aplicação (e desenvolvimento) dos modelos fundadores de Krugman (1991, 1992); Krugman e Venables (1995); Fujita, Krugman et al (1999), com Duraton (1997), Combes (1996, p. 5) como, Rychen (1998), Charlot (1999), dentre outros, que tratam de compreender as implicações intra e/ou interurbanas dos esquemas centro-periferia modelizados pela NEG; bem como os trabalhos em maior ou menor grau impregnados pelas questões centrais da NEG, como por exemplo, Ghio e Van Huffel (2000, 2001), Gaschet (2000; 2001), cuja compilação dos principais resultados se encontra em Baumont et al. (2000);

2. Periurbanização, policentralidade e metropolização: segundo a seleção de Derycke (2009), essas temáticas, na França, são compartilhadas entre as escolas de Dijon e Bordeaux. A partir do abandono do modelo monocêntrico, essas duas escolas tomam caminhos diferentes na maneira de tratar a questão da policentralidade. A escola de Dijon nos fornece uma boa quantidade de estudos que levam em consideração fatores como a preferência dos habitantes seja por externalidades ambientais positivas, seja pela existência de uma boa oferta de serviços públicos de proximidade, para explicar o fenômeno da periurbanização. Nesses estudos, os modelos multicêntricos e não monocêntricos são postos em prática a partir do dimensionamento dessas amenidades residenciais. Por outro lado, a escola de Bordeaux 
segue a linha de estudos das grandes cidades mundiais, dedicando-se à temática da metropolização, que será melhor detalhada na sequência, (GASCHET, FRÉDÉRIC; LACOUR, 2002; LACOUR, C, 1993; LACOUR, CLAUDE; CORADE, 1995; LACOUR, CLAUDE; PERRINI; AL., 2005; LACOUR, CLAUDE; PUISSANT, 1999).

3. Densificação versus espraiamento urbano: a questão da distribuição espacial da densidade urbana é bastante antiga. Partindo de Clark (1951), que estabelece a forma exponencial negativa para a curva de densidades residenciais, uma grande gama de trabalhos (cuja compilação está em Peguy, Goffette-Nagot et al. (2000) buscou descrever e explicar os fenômenos de perda de emprego e de população dos centros das cidades que se verificaram (de forma bastante contrastada) nas grandes cidades, sobretudo as norteamericanas. No nível das políticas públicas, esta temática opõe as virtudes e os problemas associados ao tipo de cidade, se compacta, densa ou espraiada. Neste último caso, a função das infraestruturas de transporte se torna crucial. É nesta temática que a escola de Lyon em Economia Urbana tem importantes contribuições.

4. Obstrução e congestionamento: em particular o congestionamento de automóveis não é mais do que um fenômeno de massificação que, de acordo com Derycke, afeta em diferentes níveis os serviços e equipamentos públicos nas cidades. Tais fenômenos de congestionamento foram incorporados à teoria urbana como no caso de Solow $(1972,1973)$. Outros efeitos que se desdobram como custos sociais decorrentes do tráfico de carros são as poluições, como poluição sonora, emissão de gases e efeito estufa. Com a expansão urbana e os deslocamentos centro-periferia, muitas pesquisas foram feitas para identificar a ocorrência desse fenômeno de congestionamento urbano como objeto de análise e de modelagem. Identifica-se que o fenômeno tem múltiplas causas: a estrutura urbanística da cidade com a estreita malha da rede rodoviária que é anterior ao surgimento dos automóveis, a insuficiência da oferta de transporte público na periferia, a dependência automobilística, as novas formas de mobilidade, policentralidades, dentre outros. Essas relações criam desafios como no caso de uma melhoria da oferta de transporte urbano com novas conexões que acaba por não diminuir necessariamente o tempo médio do congestionamento. Zahavi (1980) destaca que todo aumento de oferta de transporte aumenta também o raio médio da mobilidade potencial e alonga a distância média percorrida entre o domicílio e o lugar de trabalho, ou seja, desloca-se mais rápido e mais longe por uma duração idêntica do trajeto. É com essas questões conflitantes e paradoxais que tais fenômenos revelam a complexidade de realizar políticas de redução do congestionamento.

5. Concentração e segregação: as cidades oscilam em permanentes tendências antagônicas, como se identificou no item anterior. Elas reforçam o centro ao mesmo tempo em que se expandem para a 
periferia; elas atraem atividades e funções/cargos de prestígio e famílias de alta renda para locais também privilegiados, ao mesmo tempo em que relegam às famílias mais pobres, excluídas pelo preço da terra ou do aluguel muito elevados no centro, para bairros incertos e com carência de equipamentos públicos em regiões periféricas. Além de oferecerem empregos de pouca atratividade ou com poucas perspectivas de desenvolvimento profissional. Portanto, à concentração de riqueza e de poder no centro responde a miséria dos bairros periféricos, estabelecendo a segregação no espaço. Baron-Toe (1995) foi uma exceção à regra por parte dos economistas ao estudar esse fenômeno social de segregação no espaço urbano, juntamente com Fitoussi et al. (2004) e Maurice (2005). Para esse conjunto de trabalhos, o acesso ao emprego e a renda é difícil pelas imperfeições do mercado de trabalho e, portanto, trazem desequilíbrios locais. Esse cenário se agrava pela informação assimétrica dos candidatos à vaga e pelas práticas discriminatórias. No campo da educação Benabou (1996) e os modelos de Ogawa, Fujita $(1982 ; 1980,1989)$ e Mori tem-se a interação espacial domicílios-empresas que destaca essas configurações misturadas e separadas, evidenciando que de fato há uma segregação. Tais métodos de análise foram estudados em cidades na África do Sul depois do apartheid na tese de Selod (2002).

6. Concorrência fiscal e interações estratégicas entre os coletivos locais: essa classificação já é discutida há mais de meio século com o modelo de Tiebout (1956). Com a desconcentração e o aumento da autonomia, as comunidades foram renovadas. Os incentivos fiscais tornam-se um mecanismo de atração para as empresas, na medida em que isso incorre na redução das despesas das empresas em áreas próprias para a atividade. Para estabelecer qual seria a resposta das empresas a esses incentivos a partir da localização ótima Favardin (1996), Madies (1997), Binet (1997) e Paty (2000) trabalham essa questão em suas respectivas teses. Uma vez instaladas em determinada localização, as empresas hesitarão em se mudar novamente. Portanto, no campo teórico são estudados os tipos de relações que as empresas estabelecem, se de cooperação ou não cooperação, único ou múltiplo, simétrico ou não, estável ou instável, e assim por diante. Entretanto, esse tipo de interação estratégica é tratado quando estão no mesmo nível (local). Quando se analisa por diferentes níveis, outros problemas surgem. Como a interação de cofinanciamento ou financiamento cruzado, por exemplo Cornu (1999).

De todos esses temas, o que mais nos interessa aqui para esta tese é o da metropolização, e iremos detalhá-lo na sequência, ao compilarmos as abordagens que buscaram compreender o fenômeno de fortalecimento das grandes cidades mundiais decorrente do processo de globalização. 


\subsubsection{Os estudos das grandes cidades mundiais}

Para dar conta dessas transformações, os estudos acerca da sociedade contemporânea, em seus mais diversos aspectos e em diversas áreas do conhecimento, têm-se baseado fortemente na noção de fluxo. De forma específica, nos estudos urbanos - sejam eles feitos no âmbito da sociologia, da economia ou da geografia - os fluxos de informação, de mercadorias, de capital e de pessoas têm sido objeto privilegiado de análise. $O$ mundo da interconectividade, os avanços das tecnologias de informação (TI), a desmaterialização do trabalho e a elevação do conhecimento ao estatuto de principal moeda de troca da economia atual, levaram diversos teóricos a estudar as mudanças sociais de fins de século a partir do aumento de fluidez das relações sociais e, fundamentalmente, da possibilidade da conformação de uma sociedade em rede Castells (1999), capaz ou não de conectar certa localidade aos grandes fluxos da dita modernidade.

Se aceitarmos que passamos por mais uma "revolução" do capitalismo contemporâneo, no qual a lógica de acumulação de capital se basearia mais na capacidade de produção e acumulação de conhecimento, imaterial, portanto, do que na produção física de bens, podemos ser levados a duas conclusões. A mais simplória apontaria para o fato de que os processos de aglomeração que dão a lógica das cidades deixariam de existir e as cidades se tornariam obsoletas $^{69}$. No entanto, numa versão mais refinada, poderíamos dizer que, uma vez que todo conhecimento tem em parte um caráter tácito ${ }^{70}$, relações de face a face ainda seriam necessárias mesmo para a produção imaterial do conhecimento. Esse argumento pode declinar-se nos mais diversos azimutes: por meio da necessidade de proximidade das empresas de alta tecnologia apontada por Saxenian (1994); por meio da tirania da proximidade, que encontramos na literatura da Geografia da Inovação, cuja ideia principal poderia ser resumida na frase "ideias cruzam mais facilmente corredores e ruas do que rios e oceanos"; e por meio dos trabalhos herdeiros da Nova Economia Geográfica (NEG) de Ellison e Glaeser (1997) e Gaspar e Glaeser (1998). Nesse último, encontramos uma indicação de que o desenvolvimento das 
novas tecnologias de informação e comunicação não aboliria a necessidade de encontros face a face, uma vez que existiria uma relação de complementaridade entre encontros reais e virtuais ${ }^{71}$.

Dessa forma, os processos aglomerativos continuariam a existir e as cidades garantiriam sua perenidade. Contudo, o que daria a lógica desses processos aglomerativos seria justamente a lógica de produção, troca e acumulação de conhecimento e não mais necessariamente (ou exclusivamente) da atividade de produção física, que, com a queda dos custos de transporte, poderia se localizar onde bem entendesse. A indústria, como a conhecemos, ter-se-ia tornado footlose e a cidade, o locus privilegiado das relações sociais específicas dessa nova forma de organização do capitalismo. Distantes dos antigos burgos, das cidades mercantis onde as mais diversas feiras dominavam a paisagem e atraiam uma grande quantidade de pessoas e capitais; longe das cidades industriais, com seus excedentes de mão de obra, com sua produção em massa, com seus ganhos de escala, com seus custos de congestão; nos aproximaríamos de uma cidade de criação, tomada por spillovers tecnológicos e fertilizações cruzadas, centralizadora das decisões da produção flexível e dominada por novos e emergentes setores de prestações de serviços e de criação. Até mesmo uma nova classe social nela seria dominante. (FLORIDA, 2002)

\subsubsection{Cidades globais e cidades-região}

Quem bem identificou e descreveu esses processos e como eles impactaram o desenvolvimento das grandes cidades mundiais foi toda a literatura das cidades globais e das cidades-região. Nesta linha de trabalho podemos situar, com termos atualizados, desde praticamente toda a literatura sobre cidades globais (Sassen (1991, 1994), Mollenkopf e Castells (1991), Friedman (1986), Abu-Lughod (1995), entre outros), a das cidades-região de Scott, Stoper, Agnew, Soja (2001), até os esforços de releitura histórica da função metropolitana efetuada por Bourdeau-Lepage e Huriot (2003). 
Reconhecendo que também partem da compreensão da importância da especialização flexível como fenômeno capaz de alterar as regras da produção do espaço, a literatura das cidades-região se diferencia do grupo das teorias dos distritos industriais porque compreende que as aglomerações se dão não exatamente por relações de cooperação e transmissão de conhecimento, mas pela diminuição dos custos de transação e no aumento dos efeitos de informação e flexibilidade. Além disso, "incentiva graus crescentes de criatividade e inovação por causa da alta qualificação da força de trabalho e oferece uma grande variedade de fornecedores e de oportunidades de negócios" (MATTEO, 2011, p. 90).

No calor da virada para o século XXI, Tinoco (2001, p. 79), refletindo que apesar da perda relativa de participação na produção industrial, justamente por essa, em geral, "ter deixado de ser o motor central de uma economia internacionalizada, é que devemos buscar novos aportes teóricos e novos instrumentos capazes de aferir a real centralidade da RMSP" (p. 79), busca avaliar a pertinência da literatura das Cidades Globais e das Cidades-região para compreender essas novas centralidades.

No caso da literatura das cidades globais, Tinoco (2001) entendeu que a partir dela era possível avaliar uma nova centralidade para a RMSP baseada em que sua nova função

seria a de conectar o mercado nacional ao mercado global,
através do gerenciamento dos grandes fluxos internacionais de
capital e de mercadorias. O grande problema deste
procedimento é que não nos é possível, a partir unicamente
dessa hipótese, recuperar, conceitualmente, a centralidade da
RMSP para a dinâmica regional brasileira, para a dinâmica
interna. (TINOCO, 2001, p. 82)

Esse excessivo foco na dinâmica global dessas cidades, no entender do autor, reforçava a leitura de um processo de fragmentação da estrutura regional interna, o que, a partir dos dados disponíveis à época, já se mostrava nuançado. Por fim, entendeu que essa literatura não era capaz de explicar o novo na RMSP (o que não quer dizer que não havia algo de novo nas cidades globais de fato). O que se observava em São Paulo, na época, era que "O que São Paulo tem é seu lastro de principal cidade brasileira já há muito tempo e 
que continua a ser pelos indicadores fornecidos pela hipótese das Cidades Globais". (TINOCO, 2001, p. 111)

Por sua vez, a literatura das cidades-região se propunha justamente a superar essa limitação ao propor que essas grandes cidades deveriam ser compreendidas

a partir das transformações estruturais do capitalismo contemporâneo, não apenas a capacidade de inserção de uma grande cidade na economia global, mas sim a capacidade desta grande cidade em ser um forte pólo aglutinador da atividade econômica de seu entorno. (TINOCO, 2001, p. 112)

Desta forma, o desafio então colocado era o de buscar parâmetros e métricas de avaliação dessa nova centralidade. Para tanto, foi possível,

a partir da centralidade tipo cidade-região, que aponta a importância da aglomeração para o enfrentamento do aumento das incertezas provenientes do aumento da concorrência do capitalismo moderno, para todos os tipos de atividade econômica, é que estudamos as diferenças setoriais-regionais nos processos e intensidades inovativos para a indústria do Estado de São Paulo. (TINOCO, 2001, p. 80)

Em clara concorrência com essa literatura, veremos a seguir a contribuição da escola francesa da metropolização, a partir de seu enfoque econômico. Mais à frente, no item 2.3, vamos discutir as contribuições para além do debate interno à Economia.

\subsubsection{Metropolização na Economia}

$\mathrm{Na}$ França, esse debate sobre as grandes cidades mundiais teve uma penetração bastante grande nos diferentes centros de Economia Regional e Urbana, como nas Universidades de Dijon, Bordeaux e Lyon, sobretudo.

Demonstrando uma amplitude semântica considerável, a literatura iniciada por Corade (1993) e que em Lacour e Puissant (1999) recebeu uma primeira grande sistematização, apresenta certa dificuldade em definir claramente a especificidade de sua abordagem.

Partindo do binômio metrópole e metropolização, os autores do livro $\mathrm{La}$ Métropolisation: croissance, diversité, fractures buscam, primeiramente, sistematizar a literatura francesa sobre o debate metropolitano ocorrido nas 
décadas de 1980 e 1990, justamente no momento em que as hierarquias urbanas, marcadas até então pela forte presença de Paris em seu topo - como imortalizado por Gravier (1947) no clássico Paris et le désert français, passam por importante processo de mudança; para, em seguida, proporem uma quase interminável lista de formas e maneiras de classificar tanto o "fato urbano" da metrópole quanto o "processo" de metropolização.

Mas será essa definição assim tão importante? Como apontado por Derycke (1999) "[...] ces deux termes [metrópole e metropolização] paraissent rebelles à toutes définition simple [...]". Para o autor, uma metrópole nasce de um processo reforçado de aglomeração, proximidade e interação entre agentes reunidos num espaço denso, ao mesmo tempo em que produz a diversidade e a complexidade (DERYCKE, 1999, p. 16). A partir daí, poderia ser possível especificar um conjunto de critérios para definir uma metrópole, e muitos autores o fazem e acabam por reforçar as literaturas produtoras de rankings após rankings, sem agregar capacidade explicativa.

No entanto, apesar de dialogar e incorporar a reflexão sobre as metrópoles, Derycke (1999) indica que

L'essentiel n'est sans doute pas là ; il est de bien comprendre la nature interne des processus de métropolisation: comment se rassemblent les hommes et leurs activités, comment les secteurs moteurs du développement urbain s'enchaînent et se relaient à travers l'évolution des techniques et des modes d'organisation. ${ }^{72}$ (DERYCKE, 1999, p. 17)

Reforçando a compreensão da metropolização como um processo, Ascher (1999, p. 183) postula que "La métropolisation est donc une notion plus large qui rend compte des dynamiques de transformations" 73 , e, desta forma ela tanto pode ser instrumentalizada enquanto formas de representação, quanto "[...] d'analyse des changements sociaux et spatiaux." 74

72 - O essencial, sem dúvida, não está aí: é preciso compreender a natureza interna dos processos de metropolização: como se agrupam os homens e suas atividades, como os setores motores do desenvolvimento urbano se encadeiam e ligam através da evolução das técnicas e dos modos de organização

73 - "A metropolização é pois uma noção mais ampla que dá conta das dinâmicas de transformações" 74 - "de análise das mudanças sociais e espaciais" 
Esta característica da metropolização enquanto um processo confere a esse conceito a capacidade de lidar com a especificidade do contemporâneo uma vez que é um processo específico de nossa era.

[...] c'est incontestablement une notion plus stimulantes et finalement moins ambigu qui celles de métropole, car comme le soulignent plusieurs auteurs, des sociétés bien différentes ont connu des métropoles, alors que le processus de métropolisation est une spécificité des sociétés contemporaines. ${ }^{75}$ (ASCHER, 1999, p. 184)

Possivelmente a definição mais estruturada e completa (e também abrangente!) que podemos encontrar está em Lacour (1999, p. 64), que define a metropolização como

[...] l'ensemble des processus qui privilégient les grandes dimensions urbaines marquées par les transformations du système productif, appréhendé au niveau international et mondial. Elle conduit à des organisations et à des recompositions territoriales nouvelles, tant au plan interne des ensembles urbains concernés que sur celui de leurs relations externes. ${ }^{76}$

Num grande exercício de cobrir com a roupagem do vocábulo da metrópole-metropolização praticamente todas as linhas de pesquisa que se dedicaram a estudar diferentes processos de aglomeração espacial, é justamente com aquela que poderia ser considerada sua maior "concorrente" (e que já havia se consolidado no mundo anglo-saxão) que observamos essa amplitude semântica em funcionamento.

Plutôt que de parler de "Global Cities », On préférera évoquer des villes complètes : la métropolisation favoriserait des villes qui assurent la création, le commandement, le contrôle, la coordination et les codes, dans une perspective largement internationale de libération des échanges, d'intensification de la concurrence territoriale. Elle sous-entend aussi, à la fois un renforcement de la centralité, créée et partagée en quelques

75 - [...] é incontestavelmente uma noção mais estimulante e finalmente menos ambígua que as de metrópole, pois, como sublinham diversos autores, sociedades bem diferentes conheceram metrópoles, enquanto que o processo de metropolização é uma especificidade das sociedades contemporâneas"

76 - "[...] o conjunto dos processos que privilegiam as grandes dimensões urbanas marcadas pelas transformações do sistema produtivo, apreendido no nível internacional e mundial. Ela conduz a organizações e a recomposições territoriais novas, tanto no plano interno dos conjuntos urbanos concernidos quanto sobre o de suas relações externas 
lieux et une fragmentation accentuée des sites urbains. ${ }^{77}$ (LACOUR, C, 1999, p. 93)

Mesmo movimento observado em Derycke (1999, p. 15), em que também podemos perceber, mais explicitamente, a ideia simplificadora - e até em parte antagônica à de Ascher, indicada acima - de que metropolização seria o processo que transforma cidades em metrópoles.

Les processus cumulatifs constitutifs de la métropolisation ne jouent pleinement que si des mécanismes de coordination économique, de cohésion sociale et de régulation globale sont mis en place. C'est à cette condition que la métropole peut devenir cette " cité globale ». ${ }^{78}$

Essa ideia, de que a metrópole seria um estágio superior de uma cidade, resultado da metropolização, está ainda mais clara quando uma é colocada como um estágio da outra, que passa a ser o lugar daquilo que passa a ser central na contemporaneidade.

En fait, la métropole se distingue de la ville en ce que les processus cumulatifs d'agglomération, de concentration et d'interaction deviennent à certains stades quasiment irréversibles [...] Les métropoles deviennent des lieux concentration de l'invention, de l'innovation, de la matière grise. $^{79}$ (DERYCKE, 1999, p. 9)

No entanto, e voltando a Ascher (1999), no capítulo que faz o balanço do livro, parece que o autor pede atenção aos demais colegas, ao reclamar a primazia do conceito do processo de metropolização, que

[...] transforme les grandes agglomérations urbaines comme les plus petites [...] J'ai le sentiment qu'il faut définir et nommer les plus précisément possible ces nouveaux traits. La notion de métapole que j'ai créée à cet effet n'est peut-être pas optimale, mais elle vise à caractériser le nouveau type de formes urbaines auquel donne naissance la métropolisation, formes qui

77 - Mais que falar de «Cidades Globais », vai-se preferir evocar as cidades completas : a metropolização favoreceria as cidades que asseguram a criação, o comando, o controle, a coordenação e os códigos em uma perspectiva amplamente internacional de liberação das trocas, de intensificação da concorrência territorial. Ela subentende também, simultaneamente, um reforço da centralidade, criada e partilhada em alguns lugares e uma fragmentação acentuada dos sítios urbanos.

78 - Os processos cumulativos constitutivos da metropolização não operam plenamente se mecanismos de coordenação econômica, de coesão social e de regulação global não são postos em cena. É com esta condição que a metrópole pode tornar-se esta "cidade global".

79 - De fato, a metrópole se distingue da cidade nisso que os processos cumulativos de aglomeração, de concentração e de interação tornam-se em certos estágios quase irreversíveis [...] As metrópoles tornamse lugares de concentração, de invenção, de inovação, de massa cinzenta. 
se développent à partir des agglomérations les plus importantes, mais aussi à partir d'agglomérations plus modestes qui connaissent également la dilatation et l'éclatement de leurs territoire. La métapole se distingue donc assez profondément de la notion de métropole, car elle n'est dépendante ni d'une taille de population, ni d'un type économique. ${ }^{80}$ (ASCHER, 1999, p. 188)

\begin{abstract}
Passada a fase inicial dessa literatura, ainda no final do século $X X$, é interessante verificar como os próprios autores fazem um balanço de suas pesquisas e publicações. Lalanne e Pouyanne (2011) indicam ainda a existência de "diferentes concepções que se opõem" mas que fazem referência a processos
\end{abstract}

qui se traduisent par la concentration cumulative des richesses humaines et matérielles dans les plus grandes villes, et qui tendent à en changer leur nature. ${ }^{81}$ (LALANNE; POUYANNE, 2011, p. 8)

No entanto, deste balanço, verifica-se que, de fato, essa literatura, na Economia, não foi capaz de seguir as indicações de Ascher (1999), e continua ainda totalmente dedicada à adoração de seu totem-cidade, da grande cidade, focada na metrópole, ainda em uma perpétua rejeição ao tabu de sua superação, em direção a uma nova e diferente forma urbana. Isso fica patente quando, ao tentar definir o processo de metropolização, na realidade caracteriza as próprias metrópoles.

En première approche, le processus de métropolisation peut être cerné à partir de plusieurs caractéristiques minimales : concentration de fonctions dites "supérieures " (de contrôle et de décision, notamment) créant un milieu urbain métropolitain qui se distingue par la diversité, la complexité et la réactivité. La métropole est le lieu d'articulation de différents réseaux, elle est nœud de communication; elle est aussi le lieu de la coordination économique, au point que certains auteurs voient dans les métropoles des organisations chargées

80 - [...] transforma as grandes aglomerações urbanas como as menores delas... Sinto que é preciso definir e nomear o mais precisamente possível esses novos traços. A noção de metápole que criei para tanto não é provavelmente ótima, mas ela visa caracterizar os novos tipos de formas urbanas aos quais a metropolização dá nascimento, formas que se desenvolvem a partir das mais importantes aglomerações, mas também a partir de aglomerações mais modestas que conhecem igualmente a dilatação e e a dilaceração de seus territórios. A metápole se distingue portanto bastante profundamente da noção de metrópole pois ela não é dependente nem de uma medida de população nem de um tipo econômico.

81 - [...] que se traduzem pela concentração cumulativa das riquezas humanas e materiais nas maiores cidades e que tendem a mudar a natureza delas. 
d'orchestrer la mondialisation (les global cities à la S. Sassen); enfin, la métropole est lieu d'innovation et de création : comme telle, elle renvoie à la littérature sur la capacité d'innovation des villes et sur les creative cities popularisées par R. Florida. ${ }^{82}$ (LALANNE; POUYANNE, 2011, p. 8 negritos nossos)

E ao fazer isso, de, na realidade, não alcançar o processo de metropolização em si, processo de superação das metrópoles, continua a agenda iniciada mais de 20 anos antes de "fagocitar" toda e qualquer proposição teórica e conceitual alternativa, sempre com o olhar na cidade, que pode assumir diferentes capacidades (aqui neste caso, cinco).

La réflexion contemporaine sur la métropolisation s'articule autour de cinq thématiques : la ville globale, la ville des services supérieurs, la ville cognitive, la ville créative et la ville innovante. Le nombre important d'articles retenus fournit la preuve que l'étude des processus de métropolisation est toujours d'actualité ${ }^{83}$ (LALANNE; POUYANNE, 2011, p. 75 negritos nossos)

Poderíamos aqui fazer um paralelo: a teorização francesa acerca da metropolização, no campo da Economia, opera um movimento, nestes quase 30 anos de existência, de espraiamento conceitual sobre teorizações complementares ou alternativas, tentando trazê-las para sua hinterlândia; porém, de forma fragmentada, deixando teorizações, sobretudo as referentes aos processos de metropolização em si, desconectadas do corpo teórico geral e dos trabalhos e produção científica de maior circulação, como fixos desconectados dos fluxos.

Adicionalmente, sem dúvida nenhuma, a Economia tem produzido uma gama bastante grande de estudos acerca das cidades contemporâneas. Contudo, esses estudos têm tido bastante dificuldade de se desvencilharem

82 - Numa primeira aproximação, o processo de metropolização pode ser concebido a partir de diversas características mínimas: concentração de funções ditas "superiores" (de controle e de decisão, principalmente) criando um meio urbano metropolitano que se distingue pela diversidade, a complexidade e a reatividade. A metrópole é o lugar de articulação de diferentes redes, ela é nó de comunicação ; ela também é o lugar da coordenação econômica a ponto de certos autores verem nas metrópoles organizações encarregadas de orquestrar a mundialização (as global cities à moda de S. Sassen) : enfim, a metrópole é lugar de inovação e criação : como tal, ela reenvia à literatura sobre a capacidade de inovação das cidades e sobre as creative cities popularizadas por Florida (2002).

83 - A reflexão contemporânea sobre a metropolização se articula em torno de cinco temáticas: a cidade global, a cidade de serviços superiores, a cidade cognitiva, a cidade criativa e a cidade inovadora. $O$ número importante de artigos retidos fornece a prova de que o estudo dos processos de metropolização é sempre atual. 
das amarras metodológicas advindas do elevado grau de formalização dos modelos propostos. Um conjunto grande de novas realidades Ihes escapam, sobretudo o caráter dinâmico advindo da aceleração dos processos de globalização e de financeirização da sociedade neoliberal. Boa parte desta dificuldade se deve ao fato de elas ainda serem bastante centradas em fixos, ou seja, nos lugares em si.

Novas abordagens se impõem, com a necessidade de uma articulação maior com outros campos de conhecimento, dado que, de fato, algo novo vem ocorrendo (e não apenas a transformação mais de cidades em metrópoles) e no início do século XXI, já com cerca de 40 anos do desenvolvimento deste processo de urbanização globalizado,

Mega-regions today are accumulating even larger populations than any mega- or meta-city (defined by UN-HABITAT as a city with a population that exceeds 20 million), and their economic output is enormous. The population of China's Hong KongShenzen-Guangzhou mega-region, for example, is about 120 million, and it is estimated that Japan's Tokyo-Nagoya-OsakaKyoto-Kobe mega-region is likely to host 60 million by 2015. In Brazil, the mega-region that stretches from São Paulo to Rio de Janeiro is home to 43 million people. Although more widespread in North America and Europe, mega-regions are taking shape in Asia and other parts of the world as cities converge apace, with the typical huge demographic concentrations, large markets, significant economic capacities, substantial innovative activities and high numbers of skilled workers that come with them. Recent research shows that the world's 40 largest mega-regions cover only a tiny fraction of the habitable surface of our planet and are home to fewer than 18 per cent of the world's population, even as they account for 66 per cent of global economic activity and about 85 per cent of technological and scientific innovation. ${ }^{84}$ (UNITED NATIONS HUMAN SETTLEMENTS PROGRAMME, 2010, p. 8)

84 - Mega-regiões hoje estão acumulando ainda maiores populações do que qualquer mega ou meta-city (definida por UN-HABITAT como uma cidade com uma população que ultrapassa 20 milhões) e seu output econômico é enorme. A população da região chinesa da mega-região de Hong Kong-ShenzenGuangzhou, por exemplo, está por volta de 120 milhões e é estimado que a mega-região japonesa de Tokyo-Nagoya-Osaka-Kyoto-Kobe deve semelhantemente ter 60 milhões por volta de 2015. No Brasil, a mega-região que se estira de São Paulo ao Rio de Janeiro é lar para 43 milhões de pessoas. Embora mais espalhadas na América do Norte e na Europa, as mega-regiões estão tomando forma na Ásia e outras partes do mundo como cidades convergentes com as típicas enormes concentrações demográficas, grandes mercados, capacidades econômicas significativas, atividades inovadoras substanciais e elevados números de trabalhadores treinados que vêm com elas. Pesquisa recente demonstra que as 40 maiores mega-regiões do mundo cobrem somente uma estreita fração da superfície habitável do nosso planeta e são lar para um pouco menos que 18 por cento da população mundial, 
Para nossa surpresa, nesses últimos 20 anos, o debate sobre as transformações pelas quais as grandes cidades vinham passando foi marcado por uma proliferação de termos e tentativas de se apreender o que seria essa nova centralidade neste novo mundo globalizado e financeirizado.

Numa excelente sistematização acerca da evolução dos estudos urbanos e ecoando os conjuntos de literatura apresentados nos itens 1.2 e 2.2 desta tese, Taylor e Lang (2004, p. 951) postulam que

In the mid-20th century urban studies was established as a vibrant field of research. The treatment of cities was relatively straightforward, with the subject matter divided into two parts: the internal structure of cities and the external relations of cities. Both were formally modelled -as land-use distance models and central place hierarchy models, respectively - but most research was of a concrete nature depicting empirical patterns for particular cities (for example, factorial ecologies and hinterland studies). Generalisations of these studies linked with the formal models to provide two basic conceptual givens. First, cities were organised around central business districts surrounded by various sectors and zones, the outer being a largely residential suburbia. Second, intercity relations were organised as national urban systems structured as national urban hierarchies ${ }^{85}$.

No entanto, apesar desse conjunto de literatura fornecer um aparato sólido para a compreensão dos processos urbanos e suas transformações, os autores identificam que os estudos empíricos, em geral,

have wrestled with the problem of labelling the new emerging urban patterns. In the process the conceptual clarity of the old orthodox urban studies has been lost to history and no equivalent new clarity has taken its place. Thus there appears

mesmo que eles sejam responsáveis por 66 por cento da atividade econômica global e cerca de 85 por cento da inovação tecnológica e científica.

85 - Na metade do século XX estudos urbanos foram estabelecidos como um vibrante campo de pesquisa. $O$ tratamento de cidades era relativamente singelo, com o assunto dividido em duas partes: a estrutura interna das cidades e as relações externas das cidades. Ambas a partes eram modeladas formalmente - como modelos de distância de usos da terra e modelos da hierarquia de lugares centrais, respectivamente - mas a maior parte da pesquisa era de natureza concreta articulando padrões empíricos para cidades particulares (por exemplo, ecologias fabris e estudos do interior). Generalizações desses estudos foram ligadas com modelos formais para prover dois básicos dados conceituais. Primeiro, as cidades eram organizadas em torno de distritos de negócios centrais cercados por vários setores e zonas, sendo o exterior os subúrbios predominantemente residenciais. Segundo, as relações interurbanas eram organizadas como sistemas urbanos nacionais estruturados como hierarquias urbanas 
to be a conceptual disintegration. ${ }^{86}$ (TAYLOR; LANG, 2004, p. 954)

Essa desintegração conceitual dos estudos urbanos contemporâneos pode ser evidenciada pelo fato de encontrarmos na literatura pelo menos cem maneiras de nos referirmos a essas transformações. Nas conclusões dos autores,

\begin{abstract}
Broadly speaking, there are two ways to view the abundance of terms ... One is to celebrate the variety: the world, especially the urban world, is inherently 'messy' and therefore it is only to be expected that it should be described in multifarious ways. The other is to suspect that there is more than a little incoherent thinking abroad in contemporary urban studies. A degree of conceptual disintegration is to be expected, but this invention of concept after concept is hardly conducive to credible understanding of what is going on in and between our cities. Readers will have surmised that we are in the second camp of interpreters. We do not think we can return to the 'certainties' of a generation ago, nor would we wish to if it were possible, but we do think that we probably do not need more than a hundred new concepts to understand the spatiality of the new urbanism. Inventing new concepts is always interesting, but there must be a threshold when additional concepts obfuscate rather than illuminate. ${ }^{87}$ (TAYLOR; LANG, 2004, p. 955)
\end{abstract}

\title{
2.2.4.3 Megarregiões
}

Correndo o risco de mais ofuscarmos que iluminarmos as questões tratadas nesta tese, mas imbuídos da preocupação de nos basearmos em uma abordagem que seja, ao mesmo tempo, capaz de descrever e explicar os fenômenos urbanos contemporâneos, resolvemos compreender o que de novo o conceito de megarregião poderia agregar para buscarmos compreender a especificidade contemporânea da noção de centralidade.

86 - [...] debateram-se com o problema de classificar os novos padrões urbanos emergentes. No processo a clareza conceitual dos velhos estudos urbanos ortodoxos foi perdida para a história e uma nova clareza não equivalente tomou seu lugar. Isso aí parece ser uma desintegração conceitual

87 - Falando de modo geral, há dois meios de encarar a abundância de termos... Um deles consiste em celebrar a variedade: o mundo, especialmente o mundo urbano, é inerentemente bagunçado e assim só se espera que ele seja descrito de modos múltiplos. O outro é suspeitar que há mais do que um pequeno pensamento incoerente difundido nos estudos urbanos contemporâneos. Um grau de desintegração conceitual é previsível, mas essa invenção de conceito depois de conceito dificilmente conduz a um entendimento crível do que está ocorrendo nas nossas cidades e entre elas. Os leitores devem ter inferido que nós estamos no segundo campo de intérpretes. Não pensamos que possamos retornar para as " certezas' de uma geração atrás, nem iríamos querer que isso fosse possível, mas realmente pensamos que provavelmente não precisamos mais do que uns cem novos conceitos para entender a espacialidade do novo urbanismo. Inventar novos conceitos sempre é interessante, mas aí deve haver uma entrada quando conceitos adicionais ofuscam mais do que iluminam. 
Vale lembrar que entendemos que ela é importante, dada nossa compreensão de que experimentamos uma ruptura do processo de urbanização com a passagem do modo de produção fordista para o neoliberal, de que as metrópoles, como forma urbana típica do fordismo, precisam ser substituídas por uma forma urbana típica do neoliberalismo. E é em busca disso que desenvolvemos esta reflexão, neste momento da tese.

Para começarmos, é importante salientarmos as razões pelas quais decidimos utilizar esse conceito. Seguindo o raciocínio proposto por Harrison e Hoyler (2014, p. 1):

After all, if you look back to Peter Taylor and Robert Lang's (2004) list of 50 names given to new metropolitan forms, the term megaregion is not present. ${ }^{88}$

Primeiro, pelo fato de sua importância como fenômeno da globalização, uma vez que esse termo tem sido visto por muitos estudos como a representação da forma urbana (e não apenas da função) da globalização.

Our starting point is that despite considerable dispute over what the term might mean, an increasing number of commentators seem willing to agree that mega regions are important phenomena in globalization. One widely circulated story is that mega regions constitute globalization's new urban form. Here commentators appear convinced that the expansion of globalizing cities into larger city- regions is being superseded by trans-metropolitan landscapes comprising networked urban centers and their surrounding area. They appear captivated by a perception that what goes on in megaregions is foreboding our urban futures. ${ }^{89}$ (Harrison \& Hoyler, 2014, p. 2)

Segundo, porque essa literatura de megarregiões traz para a reflexão teórica sobre o desenvolvimento das grandes cidades uma dimensão de interrelação de diferentes sistemas urbanos. Ela acrescenta um "olhar para

88 - Depois de tudo, se você retoma a lista de Peter Taylor e Robert Lang dos 50 nomes dados às novas formas metropolitanas, o termo megarregião não está presente.

89 - Nosso ponto inicial é que apesar da considerável disputa sobre o que o termo poderia significar, um número crescente de comentadores parecem dispostos a concordar que megarregiões são importantes fenômenos na globalização. Uma estória de larga circulação é a de que megarregiões constituem a nova forma urbana da globalização. Aqui os comentadores parecem convencidos de que a expansão de cidades globalizantes em cidades-regiões maiores vem sendo suplantada por paisagens transmetropolitanas compreendendo centros urbanos conectados em redes e sua área circundante. Eles parecem cativados por uma percepção de que o que está acontecendo em megarregiões está pressagiando nossos futuros urbanos. 
fora" da antiga metrópole. Isso diferentemente da literatura sobre cidades globais que enfatizam as características da cidade em si e sua maior ou menor capacidade de se conectar à rede mundial de grandes cidades. A partir da compreensão das megarregiões, passamos a poder compreender o processo de formação da própria rede, numa abordagem que retoma para o urbano (e para o regional) o protagonismo da formação do espaço, da criação e da destruição de lugares. Não que essa preocupação não exista nas literaturas de cidades globais e de cidades-região, mas esse argumento de seu papel enquanto estruturadora do espaço regional não é parte estruturante do argumento principal.

Essa capacidade do conceito de megarregião advém de que essa abordagem, além de ser capaz de descrever a forma dessas grandes aglomerações regionais (e mundiais), é capaz também de identificar o que está subjacente a essas formas, ao enfatizar suas funções. A grande distinção se dá quando os pesquisadores

choose to prioritize mega regional form or mega regional function as their entry point. Prioritizing mega regional form leads researchers to start marking out space through observing what is visible in the physical landscape (for example urban sprawl), whereas those who prioritize mega regional function often begin by identifying what is less visible - even invisible -in the physical landscape (for example flows of knowledge and capital). ${ }^{90}$ (HARRISON; HOYLER, 2014, p. 14)

Essa escolha feita pelos pesquisadores levou à consolidação de duas escolas distintas (HARRISON; HOYLER, 2014, p. 14). Se a escola norteamericana adota uma abordagem mais formal das megarregiões, buscando e definindo critérios para a definição das megarregiões existentes, a escola europeia adota uma abordagem mais relacionada à função desempenhada por essas megarregiões.

A perspectiva baseada na forma leva Florida a enfatizar o aumento de escala, em relação às "grandes cidades do passado" ao descrever as funções

90 - (...) escolhem priorizar a forma megarregional ou a função megarregional como seu ponto de entrada. Priorizar a forma megarregional leva os pesquisadores a começar marcando o espaço através da observação do que é visível na paisagem física (por exemplo o espalhamento urbano), enquanto os que priorizam a função megarregional frequentemente começam por identificar o que é menos visível- e mesmo invisível- na paisagem física ( por exemplo fluxos de conhecimentop e capital). 
dessas megarregiões que, segundo ele, não seriam muito distintas das funções do passado em aglomerar (concentrar) fatores de produção e mercado consumidor.

\begin{abstract}
The mega-regions of today perform functions that are somewhat similar to those of the great cities of the pastmassing together talent, productive capability, innovation and markets. But they do this on a far larger scale. Furthermore, while cities in the past were part of national systems, globalization has exposed them to worldwide competition. As the distribution of economic activity has gone global, the city system has also become global-meaning that cities now compete on a global terrain. Urban mega-regions are coming to relate to the global economy in much the same way that metropolitan regions relate to national economies. ${ }^{91}$ (FLORIDA; GULDEN; MELLANDER, 2008)
\end{abstract}

Mas elas não são só maiores, são também diferentes em termos de formas. No entanto, segundo o argumento dos autores, reféns da análise eminentemente formalista, elas seriam apenas uma metrópole que cresceu, tanto se densificando quanto se conurbando. O que, de fato, não acrescenta muita coisa para a compreensão do modo como essas transformações se operam a partir delas.

\begin{abstract}
Mega-regions are more than just a bigger version of a city or a metropolitan region. As a city is composed of separate neighbourhoods, and as a metropolitan region is made up of a central city and its suburbs, a mega-region is a polycentric agglomeration of cites and their lower density hinterlands. It represents the new, natural economic unit that emerges as metropolitan regions not only grow upward and become denser but also grow outward and into one another. ${ }^{92}$ (FLORIDA; GULDEN; MELLANDER, 2008)
\end{abstract}

91 - As megarregiões de hoje executam funções que são algo similares àquelas das grandes cidades do passado- massificar juntando talento, capacidade produtiva, inovação e mercados. Mas elas fazem isso numa escala muitíssimo maior. Além disso, enquanto as cidades no passado eram partes de sistemas nacionais, a globalização as expôs à competição mundial. Quando a distribuição da atividade econômica se tornou global, o sistema de cidade também se tornou global- significando que cidades agora competem num terreno global. As megarregiões urbanas estão vindo para se relacionar com a economia global de maneira muito parecida com o modo como regiões metropolitanas se relacionam a economias nacionais. 92 Megarregiões são mais do que apenas uma versão maior de uma cidade ou região metropolitana. Assim como uma cidade é composta de vizinhanças separadas e assim como uma região metropolitana é feita de uma cidade central e seus subúrbios, uma megarregião é uma aglomeração policêntrica de cidades e seus interiores de menor densidade. Ela (a megarregião) representa a unidade econômica nova, natural, que emerge como regiões metropolitanas e não só cresce para cima e se torna mais densa mas também cresce para fora e uma dentro da outra. 
No entanto, compartilhamos com Martínez Toro (2016, p. 93) a ideia de que é necessário compreender a natureza e o alcance da influência dessas cidades no território numa sociedade neoliberal.

Se aceptan los planteamientos de Marcuse y van Kempen (2000) y Veltz (1995, 1996), en cuanto a que casi todas las ciudades son 'tocadas' por la globalización, siendo relevante en este proceso la naturaleza y alcance de su influencia en el territorio, más que el lugar que ocupan en las jerarquías o rankings. ${ }^{93}$

Por outro lado, a comparação entre as funções exercidas pelas megarregiões no mundo atual, de competição global, em relação às funções das metrópoles, dentro do arcabouço de suas economias nacionais, enfatiza apenas o declínio dos Estados nação como recorte relevante para se compreender seus desenvolvimentos contemporâneos. Nesse sentido, não aponta para uma mudança estrutural de suas funções. O contexto regional (ou global) de competição é a única variável que muda, e não a função da cidade, desconsiderando-se que, ao extrapolar as fronteiras dos Estados nação, novas funções Ihe são atribuídas, dado que é a resultante de uma mudança na forma de reprodução do capital, da passagem do modo fordista para o modo neoliberal. Com isso, essa corrente de abordagem não nos permite compreender de fato qual é a "revolução urbana" associada à globalização que não seja "apenas" uma mudança de escala, apesar de que a compreensão dessa nova escala nos seja fundamental. Reconhecendo essa limitação do conceito de megarregião, os autores indicam a agenda de pesquisa que é colocada por ele.

With this in mind, it is important to acknowledge that if the formative work on mega regions has concentrated on identifying where mega regional spaces and mega regionality are visible, the questions which are central to future agendas for research are who is constructing mega regional spaces, how are they constructing mega regional spaces, and why are

93 Aceitam-se as colocações de Marcuse e van Kempen $(2000)$ e Veltz $(1995,1996)$ quanto a que quase todas as cidades são 'tocadas' pela globalização, sendo relevante neste processo a natureza e o alcance de sua influência no território, mais que o lugar que ocupam nas hierarquias ou rankings. (MARTíNEZ TORO, 2016, p. 93) 
they constructing mega regional spaces. ${ }^{94}$ (HARRISON; HOYLER, 2014, p. 11 negritos nossos)

A discussão da sequência buscará contribuir para a compreensão acerca do quem, do como e do porquê do desenvolvimento das metrópoles fordistas em direção dessas megarregiões, características da contemporaneidade neoliberal.

Para tanto, vai tentar compreender suas novas essências constitutivas de uma cidade neoliberal, permeadas por interesses distintos, em um mundo globalizado e financeirizado, uma vez que

Después de aceptar que se está frente a una revolución urbana, más que discutir los nuevos términos que intentan dar cuenta de la emergencia de nuevos rasgos de la urbanización, se postula cómo la discusión debe plantearse inicialmente en torno a la esencia constitutiva, es decir, la explicación de sus causas y, finalmente, la caracterización de la esencia nominal en la descripción de los rasgos espaciales de tales cambios territoriales asumidos en lugares concretos. Brenner (2013) expresa la necesidad de estudiar la esencia constitutiva de la ciudad neoliberal en el marco de las dinámicas del capitalismo contemporáneo, y no en un lugar específico, un territorio particular que expresa pero que no explica las transformaciones socioespaciales producidas por agentes del capitalismo a distintas escalas en un escenario de globalización. ${ }^{95}$ (MARTÍNEZ TORO, 2016, p. 96)

Para tanto, como veremos a seguir, será a partir da conceituação de metropolização elaborada pela Geografia que conseguiremos compreender essa racionalidade como meio de apreender o movimento que permitiu a constituição das megarregiões como as conhecemos hoje.

94 - Com isso em mente, é importante reconhecer que se o trabalho formativo sobre megarregiões se concentrou em identificar onde espaços megarregionais e megarregionalidade são visíveis, as questões que são centrais para futuras agendas de pesquisa são quem está construindo espaços megarregionais, como estão construindo espaços megarregionais e porque estão construindo espaços megarregionais. 95 - Depois de aceitar que se está frente a uma revolução urbana, mais que discutir os novos termos que intentam dar conta da emergência de novos traços da urbanização, postula-se como a discussão deve situar-se inicialmente em torno da essência constitutiva, ou seja, a explicação de suas causas e, finalmente, a caracterização da essência nominal na descrição dos traços espaciais de tais mudanças territoriais assumidos em lugares concretos. Brenner (2013) expressa a necessidade de estudar a essência constitutiva da cidade neoliberal no âmbito das dinâmicas do capitalismo contemporâneo e não em um lugar específico, um território particular que expressa mas que não explica as transformações sócioespaciais produzidas por agentes do capitalismo em distintas escalas num cenário de globalização. 


\subsection{Do capitalismo neoliberal à metropolização: da centralidade cindida}

Para compreendermos o núcleo da relação entre o mundo neoliberal (do qual a financeirização é uma das partes) e os processos de formação dessas megarregiões, é importante compreendermos como que "o capitalismo contemporâneo é produtor da metropolização". (LENCIONI, 2019, p. 1)

Não podemos perder a perspectiva histórica e o sentido de hegemonia na compreensão dessa contemporaneidade:

Um capitalismo cuja hegemonia é a do capital financeiro que se
impôs como dominante e que se desenvolveu ainda nas
entranhas da supremacia do capital industrial e esse, como
sabemos, foi gestado no interior do desenvolvimento do capital
mercantil. Esse movimento de mudança na forma dominante
do capital na acumulação, expressa um continuum histórico
em que se desloca a hegemonia entre as formas do capital,
mas continuam existindo as formas desenvolvidas
anteriormente. (LENCIONI, 2019, p. 1)

\subsubsection{Valorização, capitalização e megarregiões}

Para a compreensão do processo de mudança de hegemonia do tipo de capital é importante especificar as formas de acumulação capitalista e a intrincada relação entre elas. Para além do clássico processo de valorização do capital, no qual ocorre a geração de valor por meio da extração de mais-valia a partir do uso de fatores de produção, sobretudo o da força de trabalho, (LENCIONI, 2019) chama a atenção para a importância do processo de capitalização, cuja magnitude é decorrente da "busca do capital para se valorizar fora do processo de produção" $(2019$, p. 1) e que foi possibilitado pelo desenvolvimento das finanças e das tecnologias de comunicação.

Se a busca crescente pelo processo de valorização, que necessita agrupar em um mesmo local, de forma crescente, máquinas, equipamentos e força de trabalho, está na base do processo de urbanização da consolidação das grandes cidades industriais do século $X I X^{96}$, o que decorre do fato amplamente reconhecido de que "a valorização sempre está ancorada em

96 - e que os processos de retornos crescentes, das economias de escala, teriam levado à formação de oligopólios e a polarização de regiões, segundo uma leitura de base keynesiana-perrouviana. 
algum lugar" (LENCIONI, 2019, p. 3), a possibilidade aberta pelo crescimento dos processos de capitalização teria levado à formação das megarregiões, como vimos anteriormente, com suas características de magnitude e descontinuidades, apesar da aparência inicial de que tal processo possa dar-se de forma a-espacial, "flutuando no espaço", dada a imaterialidade dos processos geradores de mais-valor.

$\mathrm{Na}$ construção teórica proposta pela autora, baseada na compreensão da relação espaço-tempo para o processo de acumulação capitalista, o lugar tem sua função, como visto acima, não apenas para o processo de valorização. Tem também importância para o processo de capitalização, uma vez que esta necessita de se realizar em infraestruturas de comunicação que, uma vez implantadas em algum lugar, funcionam como fatores de produção mobilizados pelo processo de circulação de informações e de capitais, enquanto mercadorias, e "os custos de circulação das mercadorias se somam aos custos de sua produção uma vez que a mercadoria só se realiza de fato como mercadoria quando é colocada no mercado que possibilitará o consumo dela". (LENCIONI, 2019, p. 4)

Por outro lado, essa infraestrutura de comunicação e de circulação de capitais não é homogênea nem ubíqua. Ela possui algumas características de ser ainda mais desigualmente distribuída no espaço, por ter elevado custo de implantação e, devido à rapidez do desenvolvimento tecnológico, tornar-se obsoleta muito rapidamente, o que faz com que diferentes regiões tenham diferentes qualidades de acesso a ela, gerando diferenciação espacial e, consequentemente, processos de aglomeração uma vez que "no ciberespaço operam condições que interferem na velocidade dos fluxos, [...] que influenciam na relação espaço-tempo". (LENCIONI, 2019, p. 10)

Essa desigualdade de sua distribuição no espaço não inventa novos espaços. É grande a literatura que demonstra que fatores aglomerativos do passado se somam e sobrepõem a fatores aglomerativos do presente, reforçando a centralidade de regiões já centrais.

Se destaca, en múltiples escenarios y por numerosos autores, la privilegiada posición de las metrópolis contemporáneas para servir de soporte al fenómeno de globalización y como nudo en 
las redes de comunicación e información de manera diferenciada, pero, sistemáticamente, a escala mundial. Así, se constituyen en los lugares idóneos para soportar los procesos globalizantes, debido a que ofrecen las mejores condiciones sociotecnológicas de competitividad regional y nacional. Lo anterior ocurre, debido a que proporcionan economías de aglomeración y disponen de mejores condiciones de acceso a la información y asimilación tecnológica, facilitando la difusión territorial desde su capacidad de inserción a los circuitos y redes de información regional: economía de posición, localización y relación. ${ }^{97}$ (MARTÍNEZ TORO, 2016, p. 83)

Desse modo, opera-se no processo de capitalização, ao considerarmos seu aspecto enquanto fator produtor de mais-valia (uma vez que a partir de fatores de produção), um processo de reforço daquilo observado a partir do processo de valorização. A produção de mais-valia ocorreria tanto na produção quanto na circulação da mercadoria e, em ambas, os processos diferenciadores do espaço gerariam "rugosidades" capazes de reforçar processos aglomerativos. Essas duas faces do processo de acumulação de capital tanto podem coincidir espacialmente, quando a produção fornece para o mercado local, quanto de forma separada, ou seja, com a valorização em um lugar - cidades médias, por exemplo, e a capitalização em outro - nas metrópoles, por exemplo - reforçando suas posições hegemônicas em um capitalismo cada vez mais financeirizado.

É justamente esse processo aglomerativo específico do processo de capitalização que está na base do desenvolvimento das megarregiões:

Considerar o movimento de valorização e capitalização, visto da perspectiva da relação espaço-tempo, traz à tona a geografia dos lugares; melhor dizendo, permite compreender a lógica da produção global do espaço no capitalismo contemporâneo que apresenta variadas formas, destacandose, aqui, a megarregião. (LENCIONI, 2019, p. 11)

97 - Destaca-se, em múltiplos cenários e por numerosos autores, a privilegiada posição das metrópoles contemporâneas para servir de suporte ao fenômeno de globalização e como nó nas redes de comunicação e informação de maneira diferenciada mas, sistematicamente, em escala mundial. Assim, constituem-se nos lugares idôneos para suportar os processos globalizantes, devido a oferecerem as melhores condições sociotecnológicas de competitividade regional e nacional. $O$ anterior ocorre porque proporcionam economias de aglomeração e dispoõem de melhores condições de acesso à informação e assimilação tecnológica, facilitando a difusão territorial desde a sua capacidade de inserção aos circuitos e redes de informação regional: economia de posição, localização e relação. 
Essa perspectiva nos permite compreender como se estruturam e se fortalecem os nós principais da rede mundial de cidades e como essas se fortalecem, passando a ser capazes de ampliar suas áreas de influência.

Da recuperação da importância da geografia dos lugares decorre a necessidade da reflexão acerca do que seria relevante para a compreensão da centralidade dos lugares em uma sociedade em rede, na qual novos fluxos conectam tanto velhos quanto novos lugares em que as mudanças advindas da sociedade neoliberal propiciam novas lógicas do processo de urbanização.

los cambios en los procesos productivos y en los sectores que generan riqueza a las naciones, y una nueva fase capitalista de corte neoliberal y en contexto de la globalización, han propiciado nuevas formas de ocupación y uso del territorio (Ascher (1995); Corboz (1994); Indovina (1990))98. (Martínez Toro, 2016, pp. 84-85)

A compreensão dessas novas formas de ocupação e uso do território passa pelo entendimento de que a partir destas "nuevas condiciones tecnológicas, productivas y económicas, las metrópolis contemporáneas [...] vienen a cumplir nuevas funciones en el mundo globalizado", isso porque "La globalización exige, a escala planetaria, una competitividad territorial de las metrópolis y el reforzamiento de su carácter concentrador y polarizante [...] en aquellas relaciones cada vez más multi-escalares que determinan nuevos agentes y recursos en la producción y explotación del territorio". (MARTíNEZ TORO, 2016, p. 83)

Sendo assim, essas novas funções, novos agentes e novas tecnologias, típicas no capitalismo neoliberal que vivemos, engendram uma nova forma de produção do espaço que, embora esteja associada à globalização, nela não se esgota.

Dicha revolución no es la traducción directa de la globalización en el territorio, pero, más que nunca, está influenciada y determinada por el conjunto de factores tecnológicos, económicos, financieros, políticos, sociales y culturales que se

98 - mudanças nos processos produtivos e setores que geram riqueza para as Nações, e uma nova fase capitalista de corte neoliberal e no contexto da globalização, levaram a novas formas de ocupação e uso do território 
vinculan a dicho proceso de globalización. ${ }^{99}$ (MARTíNEZ TORO, 2016, p. 93)

Suas principais características são as de reforçar e ampliar o papel de algumas das antigas metrópoles fordistas, reconfiguradas agora em megarregiões, portadoras de novas centralidades.

No entanto, para compreender a expansão dessa dessas novas forças para além da proximidade geográfica, para além de seu entorno, para além do que está fisicamente conectado, é necessário destrincharmos a noção de centralidade e o que com ela ocorre com o advento do capitalismo financeiro em contraste com o que é a centralidade fordista discutida anteriormente.

En la revolución industrial el capital instrumentalizaba a la ciudad para multiplicarse, -produciendo en ella- $y$ aprovechando el carácter concentrativo y consumista de la aglomeración y economías de escala. En la actualidad el capital utiliza la producción de la urbanización en sí misma -la ciudad y sus artefactos como mercancías - como su estrategia reproductora. ${ }^{100}$ (MARTíNEZ TORO, 2016, p. 93)

Esta abordagem expande essa perspectiva, uma vez que "na atualidade", além de o capital utilizar a produção da urbanização em si mesma e esse ser o foco principal da literatura dedicada a compreender 0 metropolitano financeiro, o capital instrumentaliza a cidade para produzir $\underline{a}$ partir dela, e não apenas nela.

Una inflexión en la urbanización que permite interpretar la revolución urbana, a la luz de los cambios morfológicos y funcionales, como un proceso que ya no puede ser descrito simplemente, como crecimiento descontrolado desde la metrópoli hacia su periferia. El territorio metropolitano se ha extendido para cubrir un espacio regional en forma de archipiélago, que además se encuentra conectado con una red

99 - Tal revolução não é a tradução direta da globalização no território, porém, mais que nunca, está influenciada e determinada pelo conjunto de fatores tecnológicos, econômicos, financeiros, políticvos, sociais e culturais que se vinculam ao dito processo de globalização.

100 - Na revolução industrial o capital instrumentalizava a cidade para multiplicar-se - produzindo nela- e aproveitando o caráter concentrador e consumista da aglomeração e economias de escala. Na atualidade o capital utiliza a produção da urbanização em si mesma- a cidade e seus artefatos como mercadoriascomo sua estratégia reprodutora. 
de interdependencia de ámbito global. ${ }^{101}$ (MARTínEZ TORO, 2016, p. 98)

Buscando destrinchar a noção de centralidade, propomos um caminho que vá para além da compreensão dos processos de geração de mais-valor, da produção, seja via valorização ou capitalização. Este caminho nos levará ao processo ampliado do capital, envolvendo tanto a produção quanto a distribuição de mais-valia e como a centralidade opera em cada um desses momentos.

\subsubsection{Os momentos da centralidade}

De acordo com (LENCIONI, 2007), o conceito de centralidade está intrinsecamente associado às noções de concentração e centralização do capital. Ao refletir acerca do desenvolvimento recente da metrópole paulista, Lencioni (2007) enfatiza a necessidade da compreensão de dois conceitos chave, muitas vezes confundidos na literatura, mas que explicam momentos distintos do capital. Desta feita, advoga "sobre a necessidade de distinguir dois conceitos para se compreender a metrópole contemporânea, 0 de concentração e o de centralização do capital, que consideramos parâmetros indispensáveis para se pensar a dinâmica urbana dos dias atuais." Lencioni (2007, pg. 8), uma vez que "permite relacionar a dinâmica do capital à dinâmica dos lugares. Em particular, possibilita discutirmos a questão da centralidade da cidade no âmago da economia urbana" Lencioni (2007, p. 11).

Para a autora, concentração e centralização figuram como dois momentos do processo de acumulação do capital. O primeiro, advindo do processo de produção, está no âmago do processo de criação de mais-valia e, portanto, da criação de valor. É a concentração de capital necessária para a valorização do valor, seja em meios de produção, seja no acesso a matérias primas. Tal processo este se dá, em sua maioria, localizado num espaço no qual o mundo topográfico impõe suas regras de tempo e distância.

101 - Uma inflexão na urbanização que permite interpretar a revolução urbana à luz das mudanças morfológicas e funcionais como um processo que já não pode ser descrito simplesmente como crescimento descontrolado desde a metrópole até a sua periferia. O território metropolitano se estendeu para cobrir um espaço regional em forma de arquipélago, que ademais se acha conectado com uma rede de interdependência de âmbito global. 
O segundo, inerente ao processo de distribuição da mais-valia, é, portanto, um processo de concorrência de capitalistas na disputa entre capitais, e não apenas na luta entre capital e trabalho na qual se dá o processo de concentração de capital e geração de valor.

Como momentos distintos no processo de reprodução do capital, têm também implicações espaciais distintas. O primeiro momento, base da urbanização industrial moderna, está associado à formação das grandes cidades fabris nas quais a acumulação de capital demandava também a concentração de grande contingente populacional, tanto para produção quanto para consumo. Com o advento da economia oligopolista, geradora de grandes desigualdades regionais, como visto anteriormente, gestou o desenvolvimento das metrópoles como as conhecemos no final do século XX.

No entanto, com o desenvolvimento tecnológico, iniciado ainda com o advento do telégrafo, mas potencializado pelas novas tecnologias de informação e comunicação e com a financeirização da economia, passou a ser possível fazer o comando sobre grandes quantidades de capital à distância, 0 que levou, como bem explica Lencioni (2007), ao processo de espraiamento das grandes cidades (efeito intraurbano) e de desenvolvimento das chamadas cidades médias no Brasil (efeito regional), em um processo de difusão do metropolitano para além de suas fronteiras.

Se observarmos apenas do ponto de vista da concentração de capital, ou seja, a partir de um pressuposto do predomínio da produção sobre a distribuição do capital, procedimento bastante comum na literatura brasileira de desenvolvimento regional, veremos apenas o processo de fragmentação da economia nacional. No entanto, ao compreendermos o segundo processo, o de centralização do capital e acirramento das disputas entre grupos econômicos regionais (oligopolizados, em geral), podemos perceber que a economia nacional está, além de fragmentada em termos de capacidade de produção de valor; também cada vez mais centralizada em termos dos processos de distribuição desse valor. Atualmente, em menos centros, centralizam-se comando, decisão e lucros, em um número ainda menor de mãos, reforçandose a importância das cidades que outrora pareciam perder protagonismo 
econômico e permitindo-se ao capital concentrar produção de valor em lugares distintos dos lugares de comando.

\subsubsection{Cisão espacial da centralidade}

Há, portanto, com o advento do capitalismo financeiro, num contexto de racionalidade neoliberal, uma possibilidade de cisão espacial entre esses dois momentos da acumulação ampliada do capital. O momento da produção de mais-valia busca novas oportunidades em lugares diversos e mesmo distantes, para concentrar recursos e fatores de produção, pondo em concorrência lugares (segundo a lógica neoliberal de concorrência generalizada) capazes de oferecer oportunidades de produção ou realização de mais valia por meio de Grandes Empreendimentos (e não mais Grandes Projetos resultantes de uma lógica de planejamento territorial orientado pelo Estado, visando políticas redistributivas e de equilíbrio regional); enquanto a disputa pela distribuição de mais valia encontra nas grandes cidades mundiais terreno fértil e recursos abundantes (infraestrutura de comunicação e força de trabalho qualificada e inserida na lógica concorrencial e empreendedora do capitalismo neoliberal), onde a disputa capital-capital é fomentada em um ambiente de desregulamentação e liberalização da economia, em que se fortalecem as posições dos grandes grupos econômicos. Com isso, o espaço relevante para a compreensão do processo ampliado de acumulação capitalista deixa de ser sintetizado por meio de oposições (cidade-campo, centro-periferia, polo-região polarizada) para ser compreendido como um todo não necessariamente contínuo, no qual a produção de mais-valia se espraia, gerando diversas concentrações regionais, enquanto a distribuição de mais-valia se localiza de modo crescente nessa rede de grandes cidades, onde se centraliza o capital nas mãos de grandes grupos econômicos.

Do pondo de vista de estruturação do urbano, simultaneamente a essa cisão espacial, assistimos ao enfraquecimento das hierarquias regionais (com seus duplos), comandadas pelas grandes metrópoles, para a consolidação e coexistência de uma estrutura em rede, conectando lugares e cujos nós fortes são as megarregiões, que assim se instalam e suplantam o esquema hierárquico comandado pelas metrópoles regionais. A esse processo foi dado 0 nome de metropolização que, por irônico que possa parecer, não se refere à 
consolidação das metrópoles e das funções metropolitanas, dado que essas são a expressão do processo de urbanização fordista, como vimos anteriormente, mas sim, e justamente, de sua superação, no momento em que elas alteram suas características e, algumas, consolidam-se em megarregiões, simultaneamente espraiando o ser metropolitano (sim, ainda fordista!) para outros lugares.

Em outras palavras, o que aqui é proposto está muito em sintonia com a proposição de Leopoldo (2016, p. 2) acerca do caráter definidor do processo de metropolização em que

We begin with the idea that metropolization involves on the one hand, the centralization of capital in major metropolitan centers and on the other, the dissemination of metropolitan content beyond metropolises and their metropolitan areas. ${ }^{102}$

Portanto, para compreendermos os processos que hoje moldam 0 desenvolvimento urbano brasileiro é necessário que compreendamos 0 processo de centralização de capital e, com isso, o momento de distribuição de mais-valia ganha relevo explicativo e um de seus fundamentos, justamente de caráter espacial, reveste-se de extrema importância: a renda da terra.

\subsubsection{Centralização de capital e produção do espaço: a importância da renda da terra}

Acompanhando 0 debate acerca dos processos de produção e apropriação do espaço urbano, propomos que a compreensão do circuito ampliado de circulação do capital nos permite entender também a produção e a apropriação do espaço regional. Para tanto, postulamos que a compreensão do papel da renda da terra nos processos que impulsionam a produção capitalista do espaço pode ser mais ampliada a partir da interrelação dos processos de produção ("produção imediata", no caso da construção civil, por exemplo) e de apropriação de mais valia e suas relações com a chamada "produção global" do espaço.

102 - Começamos com a ideia de que metropolização envolve, de um lado, a centralização de capital em centros metropolitanos maiores e, de outro, a disseminação do conteúdo metropolitano além das metrópoles e suas áreas metropolitanas. 
Do ponto de vista do espaço urbano, a pergunta corrente tem sido: "qual tipo de produção, imediata ou global, é mais relevante para compreendermos a produção do espaço urbano contemporâneo?". Questão semelhante pode ser feita para a compreensão da produção do espaço regional. Para respondê-la, como veremos, necessitamos de entender o circuito ampliado de circulação do capital.

Entre os procedimentos marxistas de conceituação dos processos de produção de valor no capitalismo, a primeira e sedutora abordagem é (e tem sido) buscar compreender a terra (ou a propriedade da terra, em abordagens mais completas) como mercadoria. Dessa forma, a partir da compreensão das forças produtivas e do caráter da luta de classes associados à produção dessa mercadoria particular, poderíamos buscar compreender como sua produção estrutura o espaço numa economia capitalista.

Contudo, para demonstrar que esse caminho não leva a uma resposta satisfatória, dada a parcialidade da aplicação da abordagem marxista quando adotada apenas segundo a ótica da produção/formação da mais-valia, buscaremos alinhar aqui alguns argumentos, a partir da leitura de Lefebvre (1999), Harvey (2015) e Marx (1980) e Marx (1983), apontando que a importância da "mercadoria propriedade da terra" (e do mercado fundiário, portanto) não se resume à exploração do trabalho pelos capitalistas em sua produção; antes, procuraremos mostrar sua importância no processo de coordenação dos usos do recurso por parte das diferentes classes sociais, de modo a compreender que:

O mercado fundiário molda a alocação de capital à terra e, desse modo, molda a estrutura geográfica da produção, da troca e do consumo, a divisão técnica do trabalho no espaço, e os espaços socioeconômicos da reprodução e assim por diante. (HARVEY, 2015, p. 474)

Num tempo em que todos os mercados se financeirizam, inclusive o mercado fundiário, é importante compreendermos que passa a ser possível moldar "a estrutura geográfica da produção" a partir também desses mercados financeiros. Isso se opera, sobretudo, a partir de tomadas de posição acionárias em empresas nas quais a propriedade da terra é um diferencial importante, gerador de expectativas quanto a rendas futuras. 
De modo geral, vamos recuperar alguns elementos-chave da teoria marxista do valor para avançarmos na compreensão do funcionamento e do papel do mercado fundiário como coordenador do processo de produção do espaço, seja ele urbano ou regional.

Primeiramente, recuperaremos, a partir de Lefebvre (1999) e Marx (1983), uma leitura abrangente sobre o processo de formação, realização e distribuição da mais-valia, com o intuito de chamar a atenção para o papel contraditório da importância da renda da terra na sociedade capitalista.

Em seguida, buscaremos argumentar que as leituras que enfatizam a análise apenas das relações de produção da mais-valia (a partir de uma leitura incompleta de $O$ Capital) obscurecem a compreensão das funções do mercado fundiário como coordenador da alocação de capital fixo, ao buscar compreender sua importância apenas enquanto mercadoria. Tentaremos, com isso, evidenciar as interrelações existentes entre a produção global e a produção imediata do espaço e, com isso, compreender a "oportunidade" pela qual se operou a cisão espacial entre concentração e centralização.

\subsubsection{A formação, realização e distribuição da mais-valia e os circuitos de acumulação}

Para compreender o papel da renda da terra no processo de produção capitalista do espaço, é necessário constituirmos o processo geral de formação, realização e distribuição da mais-valia, especificando sua ação em cada um desses processos.

Em seu capítulo sobre "O capital e a propriedade da terra", Lefebvre (1999) sistematiza as contribuições de Marx fazendo o cotejo de O Capital e os Grundrisse. Segundo o autor (1980, p. 131): "Dos Grundrisse a O Capital, o quadro muda, mas isso não é uma modificação simples. Os esboços metodológicos e teóricos incluídos nos Grundrisse, com uma certa desordem, se confirmam ... Por outro lado [n'O Capital], o encadeamento será conduzido com um maior rigor implicado já no começo: a forma pura."

Esse rigor se aplica desigualmente nos diversos momentos d'O Capital. Se a teoria da produção da mais-valia, na qual Marx efetivamente estabelece os princípios da exploração da classe trabalhadora pelos capitalistas, é 
extremamente forte e bem estruturada, sendo considerada uma obra acabada, a teoria da distribuição, segundo Harvey (2015, p. 124) sofre de imprecisões devido sobretudo ao "estado espantosamente confuso em que Marx deixou suas teorias sobre renda e juro."

Como resultado, não é de espantar que a forma canônica com que o processo de circulação de capital é comumente descrito padeça desse desequilíbrio entre as diferentes partes da teoria de Marx. Isso é bem ilustrado pelo esquema de Desai, recuperado por Harvey (2015, p. 126), no qual busca demonstrar os diferentes circuitos de acumulação de capital e suas intersecções: capital monetário; capital produtivo; e capital mercadoria.

Figura 3 - A circulação do capital

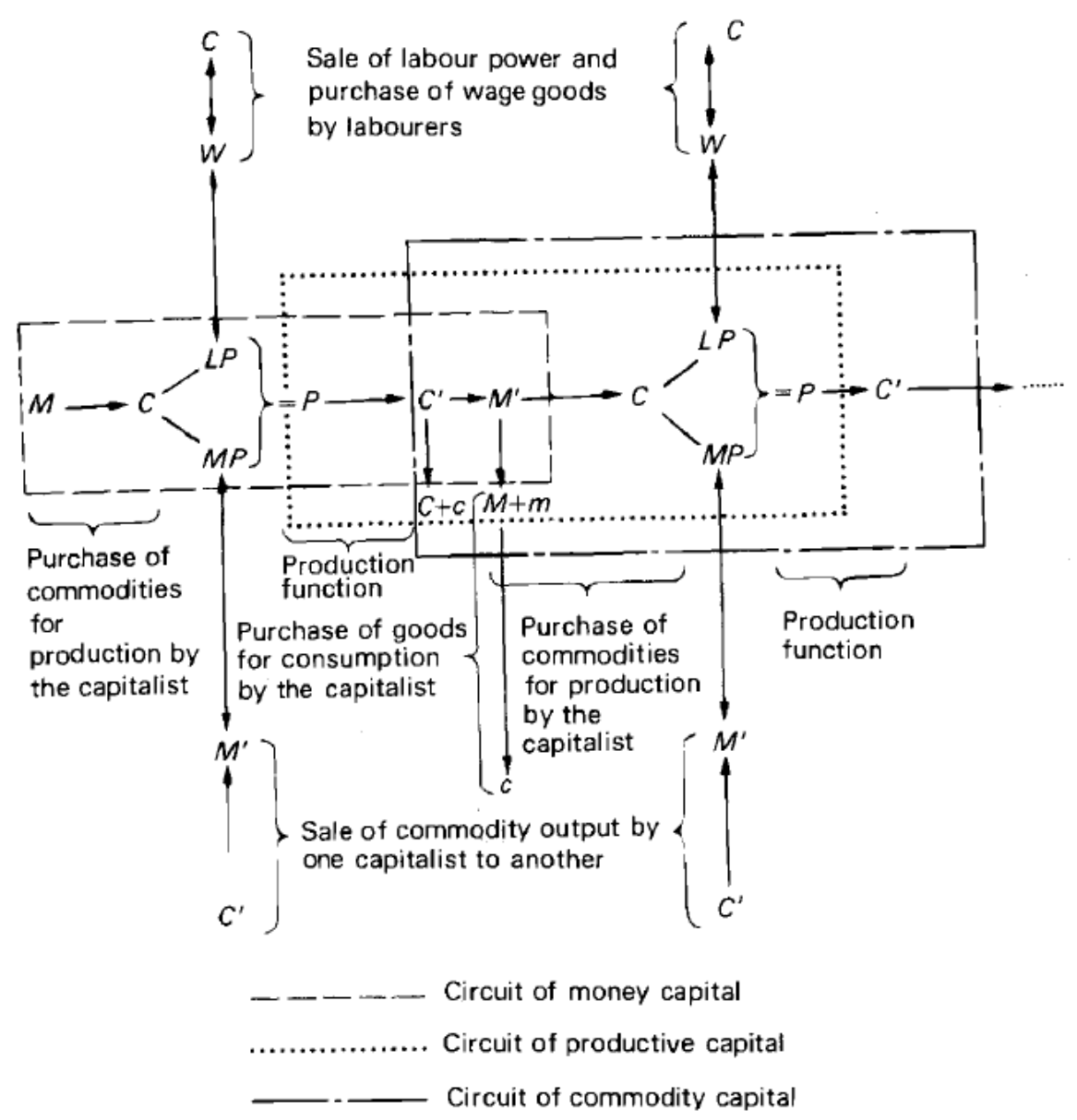

Figure 2.1. The circulation of capital (from Desai, 1979, p. 33)

O primeiro circuito engloba o processo de transformação de dinheiro em "mais dinheiro", a transformação de M (money) em M', passando pelo processo de aquisição de insumos (mercadorias e mão de obra), produção e 
comercialização. É a compreensão deste circuito que nos permite abordar o processo de realização da mais valia, quando de fato C' se converte em M', e indagar quais seriam suas regras. Neste circuito monetário, a ênfase analítica é dada ao capitalista responsável pela circulação do dinheiro, o banqueiro ou financista que por essa função recebe juros (2015, p. 125), evidenciando um dos aspectos importantes a se compreender quando o foco passa a ser a distribuição da mais-valia e não mais apenas a sua formação.

O segundo circuito foca o processo de produção em si, como, de fato, a produção $(\mathrm{P})$ é o momento de formação da mais-valia, sintetizada no fato de $\mathrm{C}^{\prime}$ ser maior do que $C$, independentemente do processo de realização como M'. É a ênfase no processo de produção, ao mobilizar a mercadoria força de trabalho, que permite que o estoque de mercadoria (valor) no final de seu processo seja sempre maior do que o estoque inicial, configurando-se como a base do processo de geração de riqueza na sociedade capitalista. Segundo Harvey (2015, p. 125):

Vemos que as condições e preocupaçães que regulam a
circulação do capital-monetário são muito diferentes daquelas
que controlam o capital amarrado como capital-produtivo a um
processo de produção específico, e que ambos são mais uma
vez diferentes daqueles que regulam a circulação do capital-
mercadoria. No fim, é claro que estamos interessados na
circulação do capital como um todo, mas na visão de Marx, não
podemos entender isso sem antes examinar suas diferenças.

Da compreensão do terceiro circuito e sua relação com os dois outros é que extrairemos alguns indicativos de análise.

O circuito do capital-mercadoria é regido pelo comerciante. É a esfera do comércio e da circulação de mercadorias. Aqui, da mesma forma que o banqueiro para o capital-monetário, o comerciante não cria valor. Sua possibilidade de extrair lucro depende de sua capacidade de se apropriar do mais-valor formado durante $\mathrm{o}$ processo de produção. $\mathrm{O}$ que permite ao comerciante a apropriação de parte desse mais-valor é que ele assume todos os custos e riscos da comercialização (incluindo o marketing) em troca de parcela desse mais-valor. Para isso, o produtor vende ao comerciante abaixo do valor da mercadoria, transferindo ao último uma parte do mais-valor junto com o risco de uma realização a preços de mercado. Na base disso estão a 
divisão social do trabalho e os ganhos de produtividade dela advindos. Um comerciante nato tem melhores entradas e conhecimento sobre o mercado que permitem realizar a mais-valia de forma mais rápida, facultando ao produtor reiniciar o processo de produção acelerando os circuitos de acumulação. Em uma economia concorrencial, sem caracterização de monopólio nem monopsônio, essa relação entre comerciante e produtor seria uma solução do tipo "ganhador-ganhador", sem configurar de fato nenhum processo de exploração.

Importante salientar que o esquema da circulação de capital de Desai demonstra a interrelação do circuito monetário e o circuito mercadoria subordinados ao circuito da produção. De fato, dada a centralidade da produção para a formação da mais-valia, o esquema aponta apenas para as condições necessárias (financeiras e comerciais) para a realização da maisvalia e a remuneração do banqueiro e do comerciante como parte necessária para a viabilização do processo de produção e, consequentemente, do processo de acumulação de capital.

No entanto, o próprio Harvey (2015, p. 126) conclui:

A desagregação dos diferentes circuitos do capital nos permite estabelecer algumas condições necessárias para regular as relações entre a produção de mais-valor e sua distribuição. Entretanto, isso não nos cria as condições suficientes que determinam os arranjos distribucionais que devem prevalecer no capitalismo.

Já Lefebvre (1999), no capítulo sobre "O capital e a propriedade da terra", aponta dois problemas a serem superados quando se quer elucidar as questões apontadas acima. O primeiro deles, também apontado por Harvey, é sobre a incompletude da obra de Marx, dado que "A teoria que deveria coroar o conjunto, a da distribuição da mais-valia [...] não mostra claramente nem os 'sujeitos' (as classes e frações de classes), nem o modo de produção constituído." (HARVEY, 2015, p. 139)

O segundo problema advém de que

[...] a maior parte dos leitores e, principalmente leitores 'sábios', procuram o que lhes convém e encontram-no aqui ou ali, ora no começo da obra (teoria da mercadoria e do fetichismo da 
mercadoria), ora mais adiante (na teoria de classes), raramente no final, na teoria da totalidade social [...]. (2015, p. 139)

Para suplantar esses problemas, como apontado anteriormente, é que Lefebvre busca uma compreensão ampliada da contribuição de Marx a partir da leitura conjugada d'O Capital e dos Grundrisse e, num segundo momento, propõe uma leitura desse processo a partir da relação do capital com a cidade. Neste processo, retoma os diferentes níveis em que a mais-valia aparece - do trabalhador individual; da empresa ou ramo industrial; e no nível da sociedade. Para compreender esses diferentes níveis, Marx analisa "sucessivamente": a) a formação da mais-valia, "pelo trabalho e pelo sobretrabalho", base do processo de exploração capitalista da classe operária; b) a realização da mais-valia, onde o circuito D-M-D' (em português) se fecha e de fato, no mercado, a maisvalia se realiza, remunerando, como vimos, os diferentes capitalistas (produtivo, financeiro e mercantil) segundo os circuitos em que atuam; e c) a distribuição da mais-valia; a esse respeito observar que "a massa da mais-valia se distribui entre suas diversas frações, inclusive, os proprietários de terra [...] Essa distribuição se efetua no nível global" lembrando que "O sistema contratual (jurídico), que o Estado mantém e aperfeiçoa enquanto poder (político), repousa na propriedade privada, a da terra (propriedade imobiliária) e a do dinheiro (propriedade mobiliária)". (1999, p. 137-138)

A questão central que Lefebvre se coloca é:

\begin{abstract}
Em que nos concerne este não acabamento? Nisto, de primeira importância: a teoria marxista da propriedade da terra no capitalismo não é completa. Como e por que uma classe de proprietários imobiliários se perpetua no capitalismo, onde predomina fortemente a propriedade mobiliária? De onde vem a renda da terra? O que ela implica? Esta questão engloba as da agricultura, da pecuária, das minas, das águas e, é claro, a do domínio das edificações das cidades. (1999, p. 139)
\end{abstract}

Dessa forma, propondo um deslocamento analítico da fábrica para a cidade, do industrial para 0 urbano, Lefebvre postula que devemos compreender o papel da cidade nos processos de formação, realização e distribuição da mais-valia para compreender a sociedade burguesa.

Segundo o autor: "A cidade como tal faz parte dessas condições históricas implicadas no capitalismo [...] Ela é coisa social, na qual são 
evidentes (tornam-se sensíveis) relações sociais que, em si, não são evidentes". Relações sociais estas de formação, realização e distribuição da mais-valia.

Lefebvre (1999, p. 142) aponta que "A cidade não tem uma função essencial" para a formação da mais-valia, apesar de, três páginas depois, dizer que "A cidade, nesta transformação, continua, portanto, a desempenhar um papel essencial, ainda que não seja propulsor" (1999, p. 145). Papel esse de contribuir "para o crescimento das forças produtivas, da produtividade do trabalho, da utilização das técnicas" (1999, p. 146). Portanto, se a cidade não é uma categoria analítica fundamental para se compreender o processo de exploração capitalista (que ocorre no interior das fábricas), ela se torna cada vez mais importante para compreender elementos fundamentais que direcionam as formas dessa exploração. Esta compreensão sobre o caráter não propulsor da cidade para a formação de mais-valia é um dos elementos que permitem a cisão espacial mencionada anteriormente. Sim, o crescimento das forças produtivas, da produtividade, necessita do desenvolvimento das grandes cidades, mas o caráter de exploração do sobretrabalho, como condição inicial do capitalismo, não depende da cidade. A formação de maisvalia pode encontrar na cidade (ou numa cidade, especificamente) condições mais favoráveis para ocorrer. Mas o que está na base da formação é a exploração do trabalho. Desta forma, a localização da produção da mais-valia pode se localizar em uma cidade em um determinado período histórico e noutra cidade, até mesmo com características distintas, em outro período, que é o que veio a acontecer a partir da crise do fordismo, por exemplo.

No entanto, o papel da cidade para a realização da mais-valia é totalmente diferente, passando, segundo Lefebvre (1999, p. 147), para o primeiro plano, dado que essa realização "exige primeiro um mercado, e, em seguida, um sistema particular de crédito, de desconto, de transferência de fundos, que permitam ao dinheiro (moeda) completar plenamente sua função", definindo a cidade como locus privilegiado dessa realização.

No entanto, é no processo de distribuição da mais-valia que o papel da cidade se evidencia e simultaneamente se torna mais complexo, uma vez que "Esta distribuição passa pelo nível mais elevado da sociedade capitalista [...] 
ela se efetua no plano econômico e no plano político". Nesse processo, também, o "Estado retém uma parte da mais-valia para pagar os gastos gerais da sociedade burguesa" (1999, p. 155). Para além da ação do Estado, a própria reprodução das relações sociais de produção é intimamente ligada à cidade, ao urbano, uma vez que "A cidade e a realidade urbana seriam, nessa hipótese, o lugar por excelência e o conjunto de lugares onde se realizam os ciclos de reprodução, mais amplos, mais complexos, que os da produção que eles envolvem. A reprodução das relações (capitalistas) de produção, em particular, implica a reprodução da divisão do trabalho, isto é, separações no interior da divisão do trabalho". (LEFEBVRE, 1999, p. 171)

Por outro lado, a cidade capitalista, marcada pela propriedade privada da terra, e pelo subsequente desenvolvimento recente do mercado imobiliário, desempenha ainda um outro papel na distribuição da mais-valia decorrente das chamadas 'rendas urbanas' assemelhadas às rendas rurais fundiárias: renda de situação (renda diferencial I) - renda de equipamento (renda II) ". (1999, p. 167)

Entendemos que o foco comumente adotado nas relações de produção leva a postular que a "produção imediata" do espaço, enquanto criação de novos estoques de "espaços" disponíveis, estaria no centro dos processos para a compreensão da formação do espaço urbano ou regional. De fato, sem ela, não haveria a produção do espaço, por não haver formação de valor. No entanto, isso não explica as regras dessa produção, ou seja, a que relações sociais ela está submetida. Dito de outra forma, a ênfase na produção imediata do espaço explica a constituição das partes integrantes desse espaço em constante produção. O que tentaremos apontar é que essa ênfase no processo de formação da mais-valia não permite a compreensão do todo (bem mais complexo do que a simples soma dessas partes) e que, para isso, é necessário entender o papel da renda da terra no processo de distribuição dessa maisvalia, sobretudo como mecanismo de coordenação dos processos de alocação de capital fixo o que, em outros termos, significa dizer do papel da renda da terra no processo de centralização de capital como processo de apropriação desta alocação e comando dessa coordenação. 
Adicionalmente, aqui se coloca mais uma questão importante. Diferentemente de se questionar qual seria a origem de valor da mercadoria terra (dado que não é produzida pelo trabalho humano), entendemos que a pergunta mais pertinente seria: como a renda da terra opera no processo de distribuição de mais-valia? Qual papel seria esse? Para compreendê-lo, é necessário compreender sua origem. Na sequência, vamos discutir seu funcionamento e suas características.

\subsubsection{A renda da terra}

Harvey (2015, p. 427), no início do Capítulo 11 sobre a teoria da renda, observa que "A teoria da renda, é justo dizer, perturbou profundamente Marx ", lembrando que seus escritos sobre o assunto foram todos publicados postumamente. Deste fato, muito possivelmente, decorre a dificuldade de sua leitura e a incompletude de suas conexões com a teoria da mais-valia, que abre uma das tantas brechas para leituras parciais às quais Lefebvre faz referência.

Apesar disso, Harvey é taxativo na síntese:

A renda, na análise final, é simplesmente um pagamento feito
aos proprietários pelo direito de usar a terra e seus pertences
(os recursos nela incorporados, os prédios nela construídos
etc). A terra, concebida nesse sentido muito amplo,
evidentemente tem tanto um valor de uso quanto um valor de
troca. (2015, p. 428)

E lança a pergunta, agora de forma mais estruturada: "Então, será que ela tem também um valor? Se tem, como a existência desse valor pode ser conciliado com as teorias do valor que se baseiam no tempo de trabalho socialmente necessário? ". (2015, p. 428)

O primeiro passo de Harvey na tentativa de responder a essa questão é decompor a renda em duas partes. Uma primeira seria referente às "melhorias incorporadas na terra", que são, diferentemente da própria terra, "resultado do trabalho humano" (2015, p. 428). O pagamento por essas melhorias, "casas, lojas, fábricas, estradas [...] produzidas como mercadorias", pode ser entendido como "um caso especial de juros sobre o capital fixo ou sobre o fundo de consumo". Portanto, a parte da renda associada ao pagamento por essas melhorias, esses investimentos em capital fixo realizados na terra, não deve 
ser considerada um mistério para a teoria da mais-valia, dado que nela seu conteúdo de valor é muito bem explicado e previsto, recebendo esse tratamento em que associa os valores pagos a título de juros sobre o capital.

O que intriga Harvey é aparentemente simples: "A parte da renda que gera problema é o simples pagamento da terra bruta, independente das melhorias a ela incorporadas. Marx se refere a esse componente como renda fundiária" (2015, p. 428). A partir daí, Harvey adota em seu livro a perspectiva de discutir a renda fundiária, que passa a chamar simplesmente de renda, deixando fora de discussão a explicação acerca do pagamento dos juros sobre as melhorias incorporadas. Portanto, podemos dizer que a exclusão da explicação dos preços pagos pelas melhorias incorporadas na terra ficou de fora da discussão por escolha consciente do autor. No nosso entendimento, ele está buscando isolar os elementos específicos da renda fundiária para poder compreender a fundo seu papel na teoria da mais-valia. O componente de explicação das lógicas de produção do espaço (inclusive o urbano) que se baseia nas regras de produção das melhorias a serem incorporadas na terra é, segundo o autor, de mais fácil compreensão, e focar a análise nelas obscurece o entendimento daquilo que de fato é intrigante e aparentemente incompatível com a teoria do valor. Resumindo, é fácil explicar o fato de uma casa ter valor, a partir dos circuitos de acumulação do capital que vimos anteriormente. No entanto, como explicar o pagamento pela terra bruta se esta não tem valor de troca?

Segundo Harvey (2015), o que está na base da possibilidade de existência da renda é o fato de a terra possuir valor de uso. Este valor de uso, por sua vez, está associado a algumas características da terra que a definem como uma mercadoria particular. $\mathrm{Na}$ sociedade capitalista, a terra é "monopolizável e alienável", podendo, portanto, ser vendida como uma mercadoria. Além disso, é um bem finito, "a quantidade total de terra na superfície da terra não pode ser significativamente aumentada ou diminuída mediante a ação humana". (2015, p. 432)

Dessas características decorre que

os valores de uso na terra e sobre a terra são "dons gratuitos da natureza" e variam em grande parte em sua quantidade e 
qualidade. Por isso, a produtividade física da força de trabalho varia segundo circunstâncias naturais, que são monopolizáveis e não reprodutíveis (2015, p. 433).

Dessa forma, o acesso às quantidades e qualidades desses "dons da natureza" é disputado no mercado pelos capitalistas que se dispõem a pagar pelo controle de condições de produção mais competitivas, fazendo surgir, portanto, o mercado imobiliário. Desta forma, a renda se define então como a remuneração pela alienação de algum monopólio não reprodutível e permanente e está regida pelas regras da concorrência.

Aqui é importante salientar que, diferentemente da teoria ricardiana, Marx não está postulando que os diferentes dons naturais sejam fontes de valor. O que ele nos mostra é que o acesso a essas condições favoráveis de produção monopolizáveis e permanentes permite ao capitalista obter uma fatia maior, via lucros excedentes, do que a mais-valia por ele produzida em seu processo de produção. Desta maneira, Marx insere a renda da terra na teoria do valor por meio de seu processo de distribuição da mais-valia (e não diretamente na formação), dado que, para alcançar esse lucro excedente, o capitalista terá de remunerar o proprietário da terra, repassando para este parte da mais-valia da qual ele conseguiu se apropriar na forma de lucro excedente, justamente por ter tido acesso a melhores condições de produção.

A síntese de Harvey a respeito da abordagem de Marx sobre a relação entre mais-valia e lucro é: "a mais-valia tem sua origem no processo de produção em virtude da relação de classe entre o capital e o trabalho, mas é distribuída entre cada capitalista segundo regras da concorrência.". (HARVEY, 2015, p. 116)

Assim, pode-se propor, a partir dos elementos anteriormente elencados, que a função da cidade nos processos de formação, realização e distribuição da mais-valia se faz presente nos três circuitos de acumulação de capital descritos por Desai (figura apresentada anteriormente) que, dessa forma, atuam no processo de formação do espaço urbano e regional. No entanto, a focalização excessiva no processo de formação encobre algumas características essenciais da produção do espaço que se encontram no processo de distribuição da mais-valia e está associado à existência da renda 
da terra que, como apontado por Harvey (2015, p. 128), "À primeira vista, não parece haver uma posição lógica para a renda na circulação do capital" da forma exposta por Desai.

Resumidamente, as relações sociais de distribuição são as que determinam a apropriação de "c", no referido esquema de Desai. Nos três circuitos de acumulação de capital nada é dito em relação àquilo no que "c" é gasto. Parte dele é consumido, mas parte substantiva remunera a renda da terra. É para isso que Harvey chama atenção ao apontar que se trata de uma outra disputa de classes, entre capitalistas e proprietários de terra. E essa disputa se dá sob as regras da renda da terra e, com isso, coordena a alocação de capital fixo, produzindo espaço e submetendo a produção imediata às regras da produção global, como veremos adiante.

Se a formação da mais-valia é uma resultante da luta entre capital e trabalho, a distribuição dessa mais-valia entre os diferentes capitalistas se dá por uma disputa entre capitais:

O efeito distributivo geral pode ser apresentado de uma maneira muito simples. Cada capitalista contribui para o maisvalor agregado total na sociedade, de acordo com a força de trabalho que cada um emprega, e se baseia no mais-valor agregado segundo o capital total que cada um adianta. (HARVEY, 2015, p. 118)

O fato de a parte da renda da terra no valor total da terra não estar descrita nos três circuitos da circulação de capital de Desai sugere que o foco no processo de formação da mais-valia por meio da tópica da "produção imediata" está longe de conseguir explicar os elementos constitutivos do processo de produção do espaço.

No próximo item, detalharemos o papel da renda da terra na teoria do valor, que confere importância à produção global do espaço e sua interrelação com a produção imediata, lembrando que "[...] vincular a origem do preço da terra a uma renda fundiária capitalizada não esgota toda a importância do que pode ser dito sobre os mercados fundiários no capitalismo.". (2015, p. 471) 


\subsubsection{O papel da renda da terra e o circuito ampliado de circulação do capital.}

Uma vez compreendida a origem da renda e, por conseguinte, explicitada a origem da parte do valor da propriedade da terra que parecia incompreensível (por não ser produto do trabalho), cabe ainda buscar compreender a função e a importância da renda no processo de distribuição da mais-valia nos circuitos de circulação de capital. Fundamental aqui notar que o reconhecimento de que a renda tem uma função importante no processo de distribuição implica necessariamente dizer que, e por causa disso, acaba por também ter uma função importante nas próprias condições de produção e formação da mais-valia. Para entender este duplo aspecto - importância na distribuição e para as condições de produção - Harvey (2015, p. 124) elabora uma comparação bastante didática e postula que "temos de considerar uma possibilidade muito real de que a renda e 0 juro desempenham papéis importantes como condições de produção."

Desta forma, Harvey está equiparando a renda ao juro como mecanismos reguladores da oferta e da demanda dos recursos aos quais seus preços fazem referência, quais sejam, a terra e o dinheiro.

Lembrando do cuidado aqui já expressado de não se fazer uma leitura estanque e compartimentada da obra de Marx, Harvey nos lembra que "a maneira sequencial da apresentação - movendo-se da produção para a distribuição da mais-valia - não deve nos levar a pensar que as relações de distribuição não têm importância para entender a produção". (2015, p. 124)

De fato, essa importância passa pela função de coordenação na alocação de recursos para o processo de produção que estas duas categorias eminentemente distributivas (renda e juro) operam na teoria do valor. Harvey estabelece um paralelo entre as funções de coordenação estratégica no modo de produção capitalista do juro e da renda: "A circulação do capital que rende juros não produz valor diretamente, mas ajuda a coordenar a produção de valor excedente [...] Então, será que a circulação do capital em busca da renda poderia desempenhar um papel de coordenação análogo?" (2015, p. 429). O que Harvey vai buscar mostrar nas páginas seguintes é que uma resposta positiva a essa questão está "profundamente enraizada nos escritos de Marx " 
(p. 429) e que essas funções de coordenação "são adquiridas à custa de permitir formas insanas de especulação da terra". (2015, p. 429)

De onde vem esse caráter especulativo (presente tanto na remuneração do juro quanto da renda)? A solução existente na teoria do valor para a atribuição de preço da terra vincula a renda da terra ao trabalho futuro que nela poderá ser comandado (diferentemente do trabalho realizado para as mercadorias comuns). Harvey sintetiza postulando que:

A teoria da renda fundiária resolve o problema de como a terra,
que não é um produto do trabalho humano, pode ter um preço
e ser trocada como mercadoria. A renda fundiária, capitalizada
como juro sobre algum capital imaginário, constitui o 'valor' da
terra. O que é comprado e vendido não é a terra, mas o direito
à renda fundiária produzido por ela [...] O comprador adquire
um direito sobre as receitas futuras antecipadas, um direito
sobre os frutos futuros do trabalho. (HARVEY, 2015, p. 471
grifos nossos)

A terra, ao permitir ao capitalista apropriar-se de "dons naturais" monopolizáveis e alienáveis, é base para comando de força de trabalho futura, para produção de mais-valia. Essa valoração futura tem esse caráter especulativo essencial para permitir a circulação do capital. Valoração essa que passa a ser "lastreada" em expectativas em relação à capacidade que um determinado capital terá de comandar força de trabalho futura. E, como expectativa, esta é bastante sensível a movimentos especulativos. A importância desta característica, segundo Harvey, é maior do que aquela que foi por Marx atribuída:

Buscando ativamente a apropriação de valores, os proprietários de terra podem impor novas configurações à produção na terra e até pressionar a produção de valor em uma escala e intensidade que do contrário não poderiam ocorrer. Assim, é claro, condenam o trabalho futuro a níveis de exploração sempre crescentes em nome da própria terra. (2015, p. 472)

Esta característica de "capital fictício" da terra, que faz com que ela realize essa função de coordenação dos usos, tanto do recurso terra quanto da força de trabalho (e também do capital fixo), é a grande contribuição da renda para a teoria do valor e é o que "legitima e justifica a apropriação da renda dentro da lógica geral do modo de produção capitalista". (2015, p. 472) 
Os proprietários de terra, na busca por melhorar a renda de suas terras, "criam um dispositivo de triagem que filtra os usos da terra e impõem as alocações do capital e do trabalho que do contrário não poderiam acontecer". Harvey aponta também que, quanto maior for o bom funcionamento desses mecanismos e quanto mais ativos forem os proprietários de terra, mais dinâmico será o mercado fundiário e "mais ajustável se tornará o uso da terra em relação às exigências sociais - no presente momento, a acumulação de capital" (2015, p. 473), apontando para o papel importante que a renda da terra tem, ao selecionar usos e alocar capital, para a formação do espaço, seja ele urbano ou regional. No entanto, uma ressalva importante e que demonstra uma certa ordenação de hierarquia entre as lógicas presentes na relação de proprietários de terra e capitalistas aponta para a compreensão da relação entre produção imediata e produção global do espaço:

No caso de uma aliança ativa entre o proprietário da terra e o capitalista, o primeiro assume o papel de arrendatário que busca captar as rendas melhoradas enquanto o capitalista busca o lucro. Situações desse tipo observadas por Marx podem muito facilmente ser criadas: as rendas aumentadas superam em muito o lucro a ser obtido do investimento direto. (HARVEY, 2015, p. 473 grifos nossos)

Harvey conclui essa passagem apontando que tanto a propriedade da terra quanto a apropriação da renda têm papel fundamental para o circuito amplo do capitalismo, no qual as relações de formação, realização e distribuição da mais-valia encontram-se intimamente interligadas, interconectadas mutuamente, e postula que "Quanto mais livremente o capital que rende juros perambular pela terra buscando títulos para os arrendatários da terra se apropriarem, melhor ele conseguirá desempenhar o seu papel de coordenador." (2015, p. 473). Essa coordenação, por sua vez, é "vital na luta para organizar o uso da terra de modo a contribuir para a produção de maisvalor e para a estruturação das formações sociais capitalistas em geral " (2015, p. 473), incluindo as formas espaciais urbanas.

Um paralelo importante pode aqui ser feito, lembrado que é a propriedade privada que coordena o processo de distribuição de mais-valia. Tanto a propriedade privada imobiliária, que coordena a alocação no espaço; quanto a propriedade privada mobiliária, que coordena a alocação de capital no 
tempo. A primeira definido o onde (a que distância) se poderá produzir; a segunda definindo o quando (por quanto tempo) se poderá produzir e, portanto, definindo onde e quando ocorrerá a produção de mais-valia.

Portanto, entendemos que, por um lado, a produção imediata (formação de mais-valia no momento da incorporação de capital fixo a partir do comando da força de trabalho no canteiro de obras) é submetida à produção global do espaço (resultante do processo de coordenação dos usos da - e na terra- , advindos da apropriação da renda) ao mesmo tempo que a possibilidade de a renda ser alterada (aumentada) por essa incorporação de capital fixo da produção imediata acaba por realimentar o processo da acumulação ampliada do capital e, por conseguinte, efetivamente operar na produção do espaço. Em outros termos, é na produção imediata que a formação da mais-valia ocorre, mas é a função da renda em coordenar espacialmente a alocação do capital fixo que mobiliza força de trabalho nessa produção da mais-valia que ocorre a produção global do espaço urbano e regional. Portanto, a questão se coloca de fato muito mais como a interrelação desses dois "momentos" da produção do espaço do que como a predominância de um ou de outro.

Esta interrelação entre esses dois momentos está no âmago da compreensão da noção de centralidade que estamos trabalhando aqui. Ao falar de centralidade, falamos de lugares que assumem determinadas características. Enquanto lugares, são, no capitalismo, monopolizáveis e alienáveis, como vimos. Enquanto lugares alienáveis, podem concentrar capital visando o comando de força de trabalho, no processo de formação de maisvalia. Permitem, portanto, enquanto lugares, a apropriação da mais-valia no presente, regida por regras de mercado no processo de realização. Por outro lado, enquanto lugares monopolizáveis, excluem a concorrência de se beneficiarem desse lugar no presente, mas também no futuro, garantindo ao detentor desse monopólio de uso o fluxo futuro de mais-valia a ser formada, futuramente, pela força de trabalho que será comandada pelo capital. Desta forma, enquanto monopolizáveis, os lugares permitem a negociação desses valores futuros no presente que, como vimos, é a base do mercado fundiário e que permite a venda de parte desse valor futuro (a um preço definido pelas expectativas em relação à mais valia futura) a valores presentes. Essa venda, 
entre capitalistas, é o que está na base dos processos de centralização de capital, como resultante da disputa capital-capital, na qual grandes grupos ampliam sua capacidade de comando diversificando sua atuação, seja em termos de tipos de produtos, setores econômicos ou de lugares de atuação.

Em suma, queremos salientar a compreensão de que a centralidade, formada por processos de concentração e centralização, como visto anteriormente, do ponto de vista analítico, pode ser entendida como um processo que opera a categoria renda da terra nessa sua dupla função. Como condição ao processo de formação de mais-valia, sendo "suporte" para a relação capital-trabalho e dessa, permitir a extração de mais-valia a partir do processo de concentração; mas também condição para o processo de distribuição de mais-valia (e seu papel de coordenação de alocação de capital fixo), na disputa capital-capital, cujo resultado é a centralização de capital nas mãos dos grupos econômicos dominantes.

Historicamente, esses dois processos se apresentam, de forma hegemônica (no sentido discutido anteriormente), de diferentes maneiras. No desenvolvimento inicial do capitalismo, ainda sob a égide liberal, da chamada concorrência perfeita (pelo menos ao nível da teorização), a concentração era praticamente dominante, havendo poucos processos de centralização. Foi a época da consolidação das cidades industriais. Com o desenvolvimento do capitalismo fordista a formação de oligopólios está intrinsecamente ligada à força dos processos de centralização, que levaram ao processo de diferenciação regional, à hierarquização do sistema de cidades e a consolidação das grandes metrópoles mundiais, como vimos anteriormente. Nesse momento histórico, concentração e centralização eram, em sua maioria, espacialmente coincidentes. Ou seja, ocorriam no mesmo lugar. Portanto, entre esses dois períodos históricos temos apenas uma diferença de magnitude dos dois processos, não configurando uma ruptura radical entre formas de urbanização.

No entanto, sob a racionalidade neoliberal a situação é bastante distinta. A financeirização da sociedade, o desenvolvimento dos meios de comunicação e a disseminação da lógica da concorrência para todos os níveis da sociedade permitiram a cisão espacial da centralidade dos lugares, passando a ser 
possível (não obrigatória) a concentração em lugares centralizados por outros. Como vimos, foi isso que levou à fragmentação das hierarquias de cidades e a constituição de uma outra camada, a de cidades em rede, comandadas à distância pelas megarregiões no processo chamado de metropolização que, desta forma, não se constitui, como visto, em um continuum dos processos de urbanização anteriores, mas sim em uma nova forma de produção de espaço. A essa nova forma foi dado o nome de Metropolização.

\subsubsection{Metropolização}

O debate apresentado até aqui descreveu a constituição e a consolidação de uma abordagem teórico-metodológica para o fenômeno urbano contemporâneo. A metropolização enquanto lógica do processo de urbanização de um mundo marcado pelo predomínio de uma racionalidade neoliberal, como descrito por Dardot e Laval (2010), vem sendo estudada por diferentes abordagens, a partir da noção de metropolização do espaço. Para além da análise da constituição em si de grandes metrópoles, inicialmente compreendidas como o crescimento das grandes cidades mundiais, buscou-se compreender, primeiro, o processo de expansão e fragmentação dos espaços de influência dessas grandes cidades, indicando um modelo de crescimento urbano bastante diferente daquele característico do processo de urbanização moderno.

Pode-se dizer com tranquilidade que o debate sobre a metropolização se inicia tendo como inspiração o trabalho pioneiro de Kayser (1969), no qual o autor define o que chamou de "espaço não metropolizado" enquanto "un 'espace restant', ceux-ci sont caractérisés par leur absence de rapports fonctionnels étroits avec une grande ville provinciale"103 (KAYSER, 1969, p. 372), evidenciando sua heterogeneidade e refletindo sobre seu "destino".

A importância das reflexões contidas em Kayser (1969) se deve ao fato de refletirem indagações presentes à época, sobre o que se poderia esperar do desenvolvimento urbano da França não-metropolitana, espaço que, nas palavras do autor, são definidos por exclusão, pela ausência, em relação aos

103 - "espaço remanescente", estes são caracterizados por sua falta de relações funcionais estreitas com uma grande cidade provincial 
espaços metropolizados e o que nestes podemos encontrar. Partindo da pergunta sobre se "L'espace non-métropolisé est-il condamné ?"104 (KAYSER, 1969, p. 376), o autor, dialogando com a necessidade de se pensar o futuro destes espaços dentro das grandes políticas territoriais francesas da época, baseadas na estratégia de fomento das chamadas "metrópoles de equilíbrio"; busca mostrar que as novas tecnologias levariam ao desenvolvimento e fortalecimento justamente desses espaços não-metropolizados. Assim, afirma que "Les futurs modèles d'urbanisation, qui devront être en accord avec la technologie d'après l'an 2000, favoriseront l'espace non-métropolisé."105, ecoando uma visão bastante forte e dominante nos anos subsequentes, de que essas novas tecnologias poderiam promover o reequilíbrio entre regiões desigualmente urbanizadas, descongestionando as grandes metrópoles, colocando os espaços não-metropolizados como uma "véritable alternative à I'urbanisation mégalopolitaine." ${ }^{106}$. (KAYSER, 1969, p. 378)

Dessa compreensão de que os espaços não metropolizados poderiam ser, no futuro, uma alternativa à quebra da "tirania" das metrópoles, não por um retorno a uma "ruralidade", ou falta de "urbanidade", mas por uma transformação a partir de um espraiamento dos conteúdos metropolitanos, é que nasce a ideia de metropolização.

Contudo, em Kayser (1969), isso se operaria por um processo onde

les progrès des techniques d'informatique et de télécommunication permettront une large décentralisation des activités tertiaires et quaternaires. Enfin, parce que l'augmentation de la part du repos et du loisir, de l'enseignement et de la culture, dans l'existence, inciteront l'homme à satisfaire ses aspirations dans un cadre spatial qui lui procure le maximum de liberté. ${ }^{107}$. (KAYSER, 1969, p. 377)

Isso nos permite dizer que Kayser (1969) conseguiu, pioneiramente, nos mostrar o movimento maior, de espraiamento de conteúdos metropolitanos

104 - O espaço não-metropolizado está condenado?

105 - O modelos futuros de urbanização, que deverão estar de acordo com a tecnologia pós anos 2000, favorecerão o espaço não metropolizado.

106 - Verdadeira alternativa à urbanização megapolitana.

107 - avanços na informática e tecnologia de telecomunicações permitirá uma ampla descentralização das atividades terciárias e quaternários. Finalmente, porque o aumento na parcela do descanso e do lazer, do ensino e da cultura, na existência, incentivará o homem para satisfazer suas aspirações em uma estrutura do espaço que the dê a liberdade máxima. 
para os espaços não-metropolitanos, metropolizando-os. Contudo, ainda com bastante antecedência em relação à consolidação das transformações estruturais da virada dos anos 2000, expressa mais um desejo, de que essas tecnologias nos permitissem quebrar a "inércia do espaço" que até então se apresentava concentradora em grandes metrópoles congestionadas. Em sua visão, a tecnologia nos libertaria das rugosidades espaciais. Contudo, sabemos e vimos que, ao contrário, a tecnologia acrescenta novas camadas de rugosidades e torna mais complexo esse movimento.

Quase 30 anos depois, à luz das grandes transformações do capitalismo contemporâneo, e após o relativo fracasso das políticas de reequilíbrio regional na França, Levy (1997, p. 1), se contrapondo à leituras como as de Kayser (1969), que, de certa forma, poderiam ser vistas como buscando negar "la tendance de l'urbanisation à épuiser le stock des populations rurales et à se localiser de manière privilégiée dans les villes préexistantes"108, se defronta com fatos indiscutíveis: "croissance des villes et notamment des plus grandes, accompagnée d'une recomposition des espaces urbains marquée par une extension et une perte de densité des espaces bâtis"109. (LEVY, 1997, p. 1)

Fatos estes que confrontam também uma grande gama de estudos que enfatizavam o fim das cidades. Levy (1997), da mesma forma que a literatura sobre Cidades Globais e Cidades-região e, futuramente, da megarregião, dirige a eles a refutação desta proclamada tendência.

Dans la dernière période, les "nostalgiques" rêvant d'une nouvelle ruralité se trouvaient rejoints par des "prophètes", qui annonçaient la fin des villes au nom de ce qu'ils estimaient être une rationalité technique : la mobilité matérielle (transports) et immatérielle (télécommunications) rendrait inutile la concentration urbaine et aboutirait à une dispersion générale des hommes et des activités. ${ }^{110}$. (LEVY, 1997, p. 1)

108 - a tendência da urbanização de esgotar o estoque de populações rurais e de localizar de forma privilegiada em cidades pré-existentes.

109 - crescimento das cidades, especialmente as maiores, acompanhadas de uma recomposição de espaços urbanos marcados por uma extensão e perda de densidade de espaços construídos

110 - No último período, os "nostálgicos" que sonham com uma nova ruralidade foram unidos por "profetas", que anunciaram o fim das cidades em nome do que consideravam ser uma racionalidade técnica: a mobilidade material (transporte) e (telecomunicações) tornaria a concentração urbana desnecessária e levaria a uma dispersão geral de pessoas e atividades 
Dessa forma, Levy (1997) identifica na generalização do uso do termo metropolização uma necessidade "d'identifier ce nouveau 'cycle' urbain, moins marqué que le précédent par les logiques spatiales de l'industrie, et de repérer les configurations correspondant à des villes qui continuent de croître". (1997, p. 1)

Necessidade essa que se satisfaz a partir de dois campos de pesquisa. O primeiro, aquele que busca compreender a continuidade do crescimento das grandes cidades. É a literatura que dialoga diretamente com a das Cidades Globais e das Cidades-região e que estão muito bem representadas, na França, pela Escola de Bordeaux, sobretudo na abordagem da Ciência Econômica, como vimos anteriormente.

No entanto, como nos foi lembrado por Ascher (1999), a agenda de pesquisa da metropolização não deveria se esgotar aí, afinal, como aponta Levy (1997) esse novo ciclo urbano, menos marcado pela lógica espacial da indústria, incide tanto em espaços metropolitanos quanto não metropolitanos. Desta forma, entendemos, e adotamos aqui a perspectiva, de que

La métropolisation n'est donc pas un simple phénomène de croissance des grandes agglomérations. C'est un processus qui fait rentrer dans l'aire de fonctionnement quotidien de ces grandes agglomérations, des villes et des villages de plus en plus éloignés et qui engendre des morphologies urbaines de types nouveaux. ${ }^{111}$ (ASCHER, 1999, p. 18)

E é justamente para compreendermos essa incorporação à lógica metropolitana de cidades cada vez mais distantes, que afirmamos ser preciso abordar os processos de concentração e centralização de capital, de forma a buscar entender a produção do espaço a partir da relação entre cidades distantes e as grandes metrópoles, na passagem de sua modernidade para sua contemporaneidade.

Lencioni (2007), a partir da compreensão da distinção entre processos de concentração e centralização, sistematiza essa ruptura entre a consolidação da metrópole moderna (que apontamos anteriormente como resultante do

\footnotetext{
111 - A metropolisização não é, portanto, um mero fenômeno de crescimento de grandes áreas urbanas. É um processo que traz para a área operacional diária dessas grandes cidades, vilas e aldeias cada vez mais remotas e gera morfologias urbanas de novos tipos.
} 
fordismo) e a constituição da metrópole contemporânea (que indicamos ser resultante do neoliberalismo, entendido em sentido amplo).

Resumidamente, para Lencioni (2007, p. 16), se a metrópole moderna é marcada por processos de urbanização, com uma aglomeração concentrada, coesa, territorialmente contínua, constituidora de redes hierárquicas, à base da concentração das atividades de produção, que caracterizam o momento de valorização do capital; a metrópole contemporânea é marcada pelo processo de metropolização, com uma aglomeração dispersa, difusa, territorialmente fragmentada, constituinte de redes anastomosadas, baseada na camada adicional do processo de centralização de capital representado pela gestão dos grandes grupos, que nelas se localizam, reforçando a importância dessas cidades no processo de distribuição do valor dentro da acumulação ampliada do capital.

Vale lembrar que isso não quer dizer que não havia centralização na metrópole moderna e que não há concentração na metrópole contemporânea. Estamos, ainda, falando de processos hegemônicos, lembrando que no mundo pré-financeirização a centralização de capital, em sua maioria, coincidia espacialmente com a concentração de capital, na constituição da centralidade dos lugares, enquanto que, na metrópole contemporânea, processos de concentração se reforçam, como os serviços às empresas, as finanças e atividades de alto conteúdo de conhecimento, mas que agora estão subordinados aos processos de centralização do capital de alcance global.

Se o processo de urbanização, constitutivo das metrópoles modernas, ainda era o reino da lógica topográfica, que "está relacionada à distância entre dois lugares e tem como referência a rede de infraestrutura de circulação" (LENCIONI, 2007, p. 17), e que, portanto, é uma lógica que estrutura lugares (fixos), hierarquizando-os, o estudo desses lugares, suas dinâmicas e trajetórias se constituiu como o principal foco da literatura de estudos urbanos em geral, como visto anteriormente.

No entanto, com a prevalência de uma lógica topológica, que "insere a distância numa lógica virtual possibilitada pela revolução da informática e comunicações [...] e no seu limite, pode chegar à instantaneidade, anulando-se o intervalo e, consequentemente, a própria distância" (2007, p. 17), os lugares, 
que eram definidos mutuamente por suas distâncias, perdem poder explicativo para os fluxos, que passam a ser as principais variáveis definidoras das dinâmicas urbanas. Desta forma, focar o estudo da metropolização na metrópole em si, quando nisso se esgota, seria não compreender a efetiva transformação entre o momento moderno e o contemporâneo.

Se o estudo dos lugares, nos capitalismos liberal e fordista, era a forma de capturarmos o urbano, com o desenvolvimento da sociedade metropolitanofinanceira esse movimento passa a ser capturado também pela compreensão dos fluxos. Sem eles, temos apenas uma "contabilidade dos lugares", e continuamos a fazer hierarquias, sem compreender que, dado que, para boa parte dos fenômenos que definem a contemporaneidade, o que explica os novos movimentos são os fluxos, temos que o metropolitano-neoliberal é global, e que conecta ou não-conecta lugares. No entanto, quando conecta, não é a distância topográfica que importa. Portanto, o estudo do processo de metropolização não deve se restringir apenas às próprias metrópoles em si, nem ao seu entorno imediato, bem como já adiantado por Ascher (1998).

A reflexão acima é importante porque muitas vezes esquecemos, quando estudamos lugares/fixos metropolitanos, que boa parte desses lugares são, na realidade, centralizados, comandados, por outros lugares numa rede bastante complexa de comando no capitalismo financeirizado global.

Seguindo a lógica da construção do argumento desta tese de compreender o processo de metropolização como a etapa do desenvolvimento das metrópoles (configuradas agora em megarregiões) num contexto de um capitalismo neoliberal, financeirizado, portanto, insistimos que essa abordagem não significa buscar compreender o processo de formação das atuais metrópoles, que entendermos terem-se constituído ainda no capitalismo fordista, por mais que ainda continuem a concentrar pessoas e capitais.

É nosso entendimento que essa concentração, que ainda se observa, mesmo que de forma dispersa (e voltaremos a esse ponto na sequência) se dê ainda em bases fordistas (como já foi dito anteriormente quando discutimos 0 caráter concentrador das atividades relacionadas ao processo de capitalização, de geração de valor nas finanças), de necessidade de proximidade física, topográfica, entre os fatores de produção. É o que justifica a concentração 
metropolitana das atividades de prestação de serviços empresariais, das atividades das finanças e das atividades de alto conteúdo tecnológico. Elas se concentram nas megarregiões por fatores de aglomeração clássicos, de necessidade de proximidade entre fatores de produção e mercado consumidor.

Contudo, cada megarregião tem também lugares não contínuos, perto e longe topograficamente, sob gestão de capitais centralizados por ela (e daí o processo de dispersão), ou concentrados nela, centralizados a partir de outras megarregiões numa cadeia bastante complexa de interdependência entre os espaços de metropolização conectados numa proximidade topológica que permite o encadeamento de estruturas de comando, que coordenam a alocação de capital fixo e atuam na distribuição do valor gerado globalmente.

Entendemos, portanto, que o processo de metropolização, como configuração da metrópole contemporânea, acrescenta aos processos fordistas, que não deixam de existir, e com eles se relaciona, como novidade explicativa, os processos de concentração e dispersão de circuitos ampliados de acumulação de capital materializados nesse encadeamento de estruturas de comando entre o conjunto das metrópoles mundiais, por onde o capital circula no processo de otimização de estratégias de enraizamento e desenraizamento nos territórios. Desta feita, afirmamos com Lencioni (2006a, p. 47) que, quando nos referimos ao processo de metropolização, "falamos tanto de um processo que transforma as cidades em metrópoles como de um processo socioespacial que impregna o espaço de características metropolitanas" e, desta forma, a "metropolização do espaço imprime ao território características que até então eram exclusivas da região metropolitana [...] fazem com que não só as práticas sociais, mas, inclusive as identidades dos lugares fiquem sujeitas aos códigos metropolitanos" (LENCIONI, 2003, p. 35).

De forma mais ampla, e indicando o caráter disruptivo do processo de metropolização, Lencioni classifica a metropolização como o "momento mais avançado" do processo de urbanização (2006b, p. 73), configurando-o como "uma segunda natureza" desta $(2015$, p. 37).

Esse aspecto disruptivo do processo de metropolização se origina no próprio processo disruptivo que a globalização e a financeirização representaram para a sociedade contemporânea, que buscamos mostrar 
quando discutimos a emergência de um momento metropolitano-neoliberal do capitalismo, e do qual a metropolização é a expressão socioespacial, conforme (LENCIONI, 2006a, p. 72)

A metrópole contemporânea pode ser considerada uma espécie de tradução urbana da manifestação sócio espacial da globalização. Ela apresenta uma forma territorial nova, que pode ser descrita como uma ampliação da metrópole moderna, herdada do processo de urbanização e industrialização. Ela é produto do processo de metropolização, que nada mais é do que uma metamorfose do processo de urbanização.

Essa metamorfose do processo de urbanização, produto da metamorfose do capitalismo contemporâneo, permite que a metrópole contemporânea guarde características da metrópole moderna, oriunda da urbanização fordista, e que, como vimos, está baseada na importância ainda presente de processos de concentração de capital em lugares capazes de gerar efeitos aglomerativos para as mais diversas indústrias, inclusive as indústrias de serviços (das quais a "indústria dos fundos financeiros" trabalhada por Pessanha (2019) é uma).

Ao mesmo tempo, essa metropolização, baseada, sobretudo, na cisão da noção de centralidade dos lugares, permitida pelo capitalismo metropolitano-neoliberal, como vimos anteriormente, permite concentrar capital em proximidades topológicas mesmo que a distâncias topográficas, ou seja, permite ao capital comandar enraizamento de capital fixo em lugares que não possuem capacidade de centralizar tal capital, sendo centralizado por agentes econômicos localizados dispersamente na rede de cidades globais que comandam a economia mundial, em geral metrópoles modernas que estão em transição, justamente por sua capacidade de centralizar capital concentrado à distância, para um padrão de metrópole contemporânea.

Importante frisar que essa metamorfose gera outro processo urbano.

A expansão territorial da metrópole constitui uma região, precisamente uma região metropolitana de outro tipo, o que não pode ser confundida com a região metropolitana relacionada ao processo de industrialização e urbanização que caracterizaram grande parte do século XX. (LENCIONI, 2006a, p. 72) 
Processo urbano esse que está fortemente enraizado na forma hegemônica de acumulação capitalista de nossa época metropolitanoneoliberal, associada às finanças. Portanto, para muito mais além do que a simples concentração (mesmo que dispersa) das atividades e pessoas nas metrópoles contemporâneas, o conceito de metropolização mobiliza novas lógicas do processo de produção do espaço, associadas à reprodução ampliada do capital, englobando a compreensão da simultaneidade dos momentos de produção e distribuição de mais-valia, que nos permitem compreender não só o processo de produção do espaço na própria metrópole contemporânea, como o fez, por exemplo, Leopoldo (2018), para citar apenas o estudo mais recente, como também nos permite avançar para a compreensão da formação dos espaços regionais sob a égide do capitalismo metropolitanoneoliberal, uma vez que não apenas a metrópole (neste caso a moderna, ao se tornar contemporânea) foi colocada a serviço do capital, mas todo o "metropolitano", como "reprodução ampliada da metrópole", a partir do processo, e como resultante, da metropolização.

Desse modo, a metropolização não significa a concentração nas metrópoles e suas regiões metropolitanas, mas o novo momento da produção do espaço. Nesse movimento, a reprodução ampliada da metrópole foi colocada à serviço do capital, visto que a metropolização se tornou também um negócio. (LEOPOLDO, 2018, p. 93)

Em total sintonia com Leopoldo (2018), entendemos que o estudo do processo de metropolização pode tanto ser focado na compreensão da transição entre a modernidade e a contemporaneidade das metrópoles quanto focado na compreensão da metropolização para além das metrópoles, que também se configuram como momentos de "metropolização do espaço".

Em outras palavras, a metropolização do espaço vai para além das metrópoles e regiões metropolitanas, pode estar por toda parte, inclusive em áreas ditas agrárias ou pequenas aldeias. Não é apenas a paisagem metropolitana com a presença massiva de objetos metropolitanos que configuram momentos da metropolização do espaço, mas também os lugares onde chegam com mais ou menos velocidade e intensidade as representações e valores metropolitanos, emanados da metrópole, que crescentemente ganham a totalidade do espaço mundial. Esses espaços não são necessariamente metropolitanos, mas fazem parte da lógica metropolitana e 
reproduzem a "economia metropolitano-financeira" (LEOPOLDO, 2018, p. 92-93)

É com esse olhar para esses espaços que "não são necessariamente metropolitanos", como o baixo Tapajós, que pretendemos contribuir para a compreensão dos processos de formação de espaço numa sociedade metropolitano-neoliberal, buscando somar esforços com aqueles que estudam as próprias metrópoles, para compreendermos a amplitude dos processos sociais produtores de espaço e sociabilidades no capitalismo contemporâneo.

\subsubsection{Metropolização do espaço}

Nesta transição do moderno para o contemporâneo, as concentrações de capital centralizados pelas metrópoles contemporâneas espraiam para os demais lugares (no processo de coordenação da alocação de capital fixo orientado pela renda da terra), sejam eles a proximidade não contínua, ou mesmo a distâncias topográficas bastante grandes, processos de valorização de capital, de produção e apropriação de mais-valia, de atividades portadoras da lógica metropolitano-neoliberal.

Esse processo imprime ao território características
metropolitanas não importando o porte da cidade. Esse é o
caso, por exemplo, de algumas cidades litorâneas
reconvertidas pela atividade turística por meio da atuação do
grande capital, a exemplo de Cancun, que apesar do porte
urbano apresenta características que, até então, eram
exclusivas das metrópoles, como a presença de um aeroporto
internacional. Ou, o caso de cidades de porte médio que por
estarem diretamente relacionadas à economia global
apresentam algumas condições gerais de produção e
determinados serviços que, anteriormente, só eram
encontrados nas metrópoles modernas. (LENCIONI, 2006a, p.
72)

Em seu estudo que busca compreender a potência da teorização acerca da metropolização para a compreensão de espaços não metropolitanos, Soares (2018) sintetiza a agenda de pesquisa sobre esse tema em três frentes:

(1) a metropolização como a difusão regional da dinâmica metropolitana; (2) a metropolização como conexão dos espaços urbanos aos circuitos hegemônicos da economia globalizada; e (3) a metropolização mobilização de agentes 
políticos, econômicos e sociais regionais visando ao desenvolvimento regional conectado à economia metropolitana. (SOARES, 2018, p. 29)

A primeira frente, talvez a mais conhecida e explorada, busca estudar 0 "processo espacial de difusão e concentração das condições gerais de produção (infraestruturas) para a acumulação ou de difusão da dinâmica metropolitana". (2018, p. 29)

Nesta frente, verifica-se uma leva de estudos que buscam compreender como essa lógica de conformação dos espaços metropolitanos se replicam e espraiam em outros espaços, emprestando-lhes características novas, que os aproximam das características das grandes cidades mundiais. Essa bibliografia é farta em buscar demonstrar a predominância dessa lógica de metropolização para o desenvolvimento urbano brasileiro, indicando como que características metropolitanas passam a ser encontradas em diversas cidades brasileiras, em especial em algumas capitais ou regiões metropolitanas. ${ }^{112}$

No entanto, como visto anteriormente, para além da identificação dos conteúdos, se metropolitanos ou não, presentes em uma determinada cidade ou região, é de suma importância, para a compreensão do processo de metropolização, o entendimento do processo de estruturação das redes de comando e controle entre os diferentes espaços metropolizados. No nosso entendimento, para a compreensão das dinâmicas contemporâneas produtoras de espaço, passa a ser relevante identificar os elos de conexão entre esses espaços à luz do desenvolvimento dos processos de financeirização e de espraiamento da racionalidade neoliberal.

Para além de se buscar "características metropolitanas" nos diferentes espaços regionais, defende-se aqui a abordagem que busca "o outro lado da moeda", ou seja, se a metropolização é marcada pela centralização do capital, e seu respectivo poder de comando e controle, entendemos ser relevante e importante sermos capazes de demonstrar o quanto algumas regiões e/ou cidades são, ou passam a ser, "comandadas e controladas" a partir de uma ou várias regiões metropolitanas, sedes de grandes grupos empresariais e fundos

112 - Lembrando que utilizamos aqui a expressão região metropolitana apenas em seu sentido administrativo. 
de investimentos, independentemente de sua posição relativa na hierarquia urbana de sua região de inserção. Esta abordagem se filia à segunda frente indicada por Soares (2018), que indica que

\begin{abstract}
do ponto de vista econômico, implica a relação do processo de metropolização com os modelos de desenvolvimento mais ou menos territorializados, podendo aproveitar das vantagens comparativas dos sistemas produtivos locais, ampliá-las a partir de circuitos de cooperação e inovação e conectá-las com a economia global. (2018, p. 29-30)
\end{abstract}

A terceira frente, menos estudada empiricamente aqui no Brasil, discute a "constituição política das aglomerações metropolitanas" na qual "os atores regionais criam uma nova escala de poder e articulação regional, com o caráter e o alcance regional, mas profundamente relacionado com o metropolitano e 0 global”. (SOARES, 2018, p. 30)

Como vimos anteriormente, o baixo Tapajós, especificamente Itaituba, vem sendo o locus de desenvolvimento de várias frentes econômicas nas últimas décadas. De sua tradição minerária, passando pelo avanço da fronteira do agronegócio como expansão da produção da soja vinda do Mato Grosso e, sobretudo, da consolidação do Corredor do Tapajós e seu caráter de intermodalidade que conecta as extensas áreas de produção agrícola com os portos de exportação por meio do desenvolvimento de diversas estações de transbordo de cargas (ETCs).

Portanto, dentre as características monopolizáveis (fundamentais para a constituição da renda da terra) que a propriedade da terra na região de Itaituba hoje permite alcançar estão tanto o acesso a recursos minerários quanto às extensas áreas para produção de soja inseridas em rota privilegiada de escoamento. Além disso, e mais recentemente, o acesso à oportunidade de um posicionamento logístico adequado permitir a apropriação da mais-valia produzida pelo agronegócio em todo o Centro-Oeste, que hoje tem seu escoamento feito através de portos do Sul e Sudeste. Não à toa é que os principais players que hoje buscam se instalar na região com ETCs são ou produtores de soja do Mato Grosso ou as grandes empresas compradoras dessa soja, como Bunge e Cargill, numa disputa acirrada para conseguir se 
apropriar da economia que o escoamento feito pelos portos do Norte propicia em relação aos demais.

Sendo assim, postula-se que é possível buscar compreender a formação do espaço regional do baixo Tapajós a partir da abordagem marxista do valor, quando entendido a partir do circuito ampliado de circulação do capital, como visto acima, tanto no aspecto do desenvolvimento de alguns loca de concentração de capital, produtor de valor, quanto no papel que a busca (da parte de grandes empresas e fundos de investimentos cuja centralização comanda esse capital à distância) por localização estratégica no processo logístico de escoamento da produção de grãos tem para a captura de maisvalia produzida em outros locais, no processo de distribuição.

A compreensão da produção do espaço regional se evidencia pressupondo-se essa simultaneidade de processos e circuitos do capital que caracterizam tanto os processos de concentração quanto de centralização de capital, evidenciando, desta forma, a capacidade que o conceito de metropolização tem, ao se basear na leitura simultânea desses dois processos, de explicar o processo de urbanização contemporâneo, mesmo na região amazônica.

Desta forma, no próximo item, vamos lançar o olhar sobre a dinâmica econômica atual do Baixo Tapajós e a maneira como este se insere, hoje, na lógica de metropolização do espaço nacional. Nesta análise, atenção especial será dada às características dos grandes investimentos que vêm ocorrendo ou estão previstos para a região. 


\subsection{O Baixo Tapajós no início do século XXI}

Itaituba entra no século XXI trazendo consigo a herança do período colonial e a de seu desenvolvimento como cidade em uma sociedade urbanofordista, como visto no item 1.3. Tais características e tendências não deixam de existir e não são superadas por novas. Aqui, indicaremos movimentos novos, específicos do momento metropolitano-neoliberal, que apresentam novos elementos para refletirmos acerca do desenvolvimento urbano do baixo Tapajós.

Após termos compreendido como Itaituba teve sua centralidade fordista alterada (e, consequentemente, tendo também sua hierarquia alterada) pela implantação de grandes projetos no final do século passado, poderíamos ser tentados a continuar adotando o arcabouço das teorias de localização (no caso da REGIC) ou das teorias de polarização para compreender o que está ocorrendo e o que pode vir a ocorrer com a centralidade de Itaituba desde a implantação de grandes empreendimentos no início deste século XXI. Desta maneira, poderíamos ser tentados a perguntar qual seria sua nova posição no sistema de cidades do baixo Tapajós, a partir de sua relação com Santarém, com as cidades por ela centralizadas ou até mesmo, devido à sua crescente conexão com o agronegócio do Mato Grosso, se, neste momento, ela não estaria passando a ser polarizada por Alta Floresta e até mesmo Sorriso, numa reconfiguração radical, mas possível, das redes de cidades associadas ao agronegócio.

De fato, esta seria uma tentadora linha de pesquisa. No entanto, como vimos, teria de recorrer a arcabouço teórico desatualizado em relação ao presente momento histórico e, com isso, poderia não captar importantes novas tendências do desenvolvimento urbano da região, que se somam às tendências existentes.

Pela perspectiva de que esse desenvolvimento contemporâneo de Itaituba esteja associado ao momento metropolitano-neoliberal do capitalismo, entendemos que é preciso buscar compreender como que as características marcantes deste momento histórico se estariam apresentando (ou não) nessa 
região. Para tanto, tivemos um olhar bastante aberto para expressões locais da racionalidade neoliberal, conforme apontada por Dardot e Laval (2010b), sobretudo no que tange ao caráter global e financeirizado de sua inserção nos circuitos ampliados de acumulação de capital.

Como já indicado, o município de Itaituba hoje é considerado foco de um conjunto de investimentos produtivos e de infraestrutura em andamento no Estado do Pará, dos quais se destacam o Complexo Hidroelétrico do Tapajós e - Corredor Logístico do Tapajós, parte integrante do chamado Arco Norte. Esses investimentos, caracterizados como grandes empreendimentos, podem ser considerados como os principais vetores de possíveis novas espacialidades, a partir da virada do século XXI. Eles são constituídos por projetos que vão da construção do Complexo Hidrelétrico do Tapajós, composto pelas usinas de São Luiz do Tapajós, Jatobá, Jamanxim, Cachoeira dos Patos e Cachoeira do Caí; e pela constituição do Corredor Logístico do Tapajós.

Esse corredor logístico é um dos elementos estruturantes do Arco Norte - alternativa de escoamento da produção agropecuária do Centro-oeste vias portos do Norte - que contará com o asfaltamento das rodovias federais BR230 (Transamazônica) e BR-163 (Cuiabá-Santarém), a viabilização da Hidrovia do Tapajós, que deverá interligar a o norte do Mato Grosso, a partir da Cidade de Apiacás, até o Porto de Santarém. Hoje, essa hidrovia tem uma parte navegável, a partir das cachoeiras de São Luiz do Tapajós até Santarém, passando por Itaituba, e um trecho ainda não navegável, que necessita de dragagem e de retirada de pedras. Além disso, a parte não navegável da Hidrovia do Tapajós hoje tem seu uso disputado com a implantação das usinas hidroelétricas. Para que seja implantada definitivamente, os projetos hidroelétricos precisam passar por ajustamento, para prever esse compartilhamento de uso, o que acarretará um encarecimento dos projetos. Por último, ainda em fase de projeto, completará o Corredor a implantação da Ferrogão, ferrovia que pretende interligar a cidade de Cuiabá a Santarém, cujos estudos para o trecho entre Sinop-MT e Itaituba já se iniciaram, com um traçado semelhante ao da BR-163. Os principais elementos constitutivos do Corredor Logístico do Tapajós encontram-se no Mapa 2 abaixo. 
Mapa 2 - Corredor Logístico do Tapajós

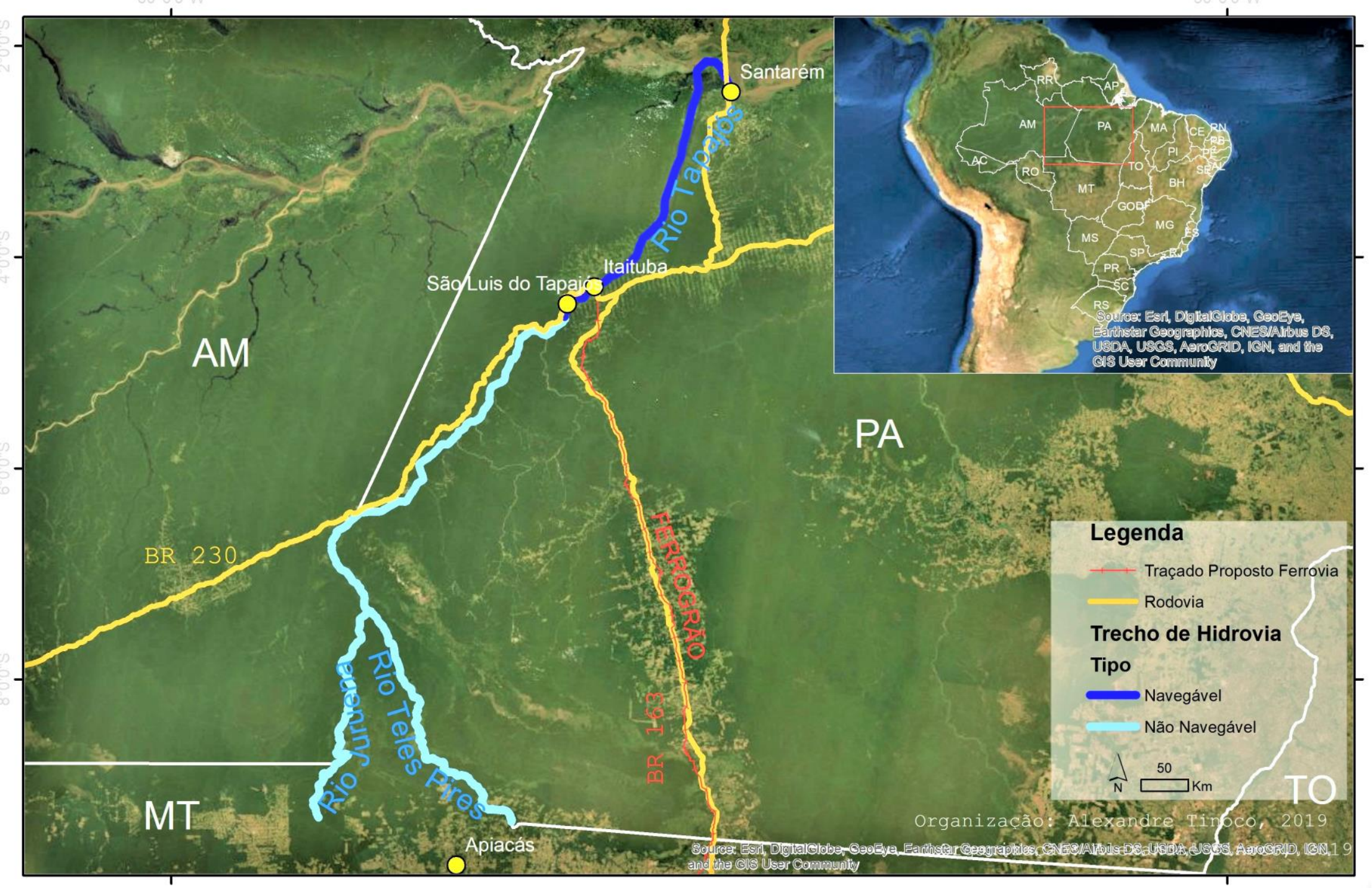


Para a viabilização deste corredor logístico multimodal é necessária a implantação de várias estações de transbordo de cargas (ETC) nas imediações de Miritituba (localizado em Itaituba) e Fordlândia (localizado em Aveiro), que analisaremos na sequência.

A importância e o montante desses investimentos nos levam a tentar compreender quais novas lógicas de uso do espaço eles podem estar trazendo para a região. Assim, decidimos realizar uma visita à Secretaria de Meio Ambiente e Sustentabilidade do Pará (SEMAS) no primeiro semestre de 2017, quando pudemos constatar a consolidação de um montante bastante elevado de investimentos em curso na região, sobretudo em atividades de logística, com a implantação de Estações de Transbordo de Carga (ETC), que visam a consolidação do Corredor Logístico do Tapajós como alternativa infraestrutural para o escoamento e a exportação da produção de grãos do agronegócio do Mato Grosso.

A partir desses dados, vamos verificar a consolidação dessa função logística de escoamento da produção agrícola do Centro-Oeste brasileiro, sobretudo de soja e milho, sob uma perspectiva de integração produtiva global, tendo como mercados principais a China e a Europa.

Poderemos também especificar como a constituição dessa função logística nova é fruto da lógica neoliberal de uma intricada relação entre Estado e interesses privados, em um movimento que não é nem resultante quase exclusivamente de projetos estatais de investimentos, nem apenas da atuação livre dos interesses privados. Tal racionalidade neoliberal imprime uma lógica de concorrência generalizada nesse e desse território com outros, que fazem ou podem fazer parte da mesma cadeia capitalista de valor.

Por último, mostraremos como essa consolidação vem ocorrendo segundo uma lógica financeirizada, imprimindo a esses territórios características novas que, como vimos, são específicas do momento metropolitano-financeiro. Como resultante, mais do que buscarmos compreender como que a centralidade de Itaituba estaria se rearranjando e reconfigurando segundo os esquemas urbano-fordistas de hierarquia de cidades e o quanto ela estaria se aproximando de Santarém ou concorrendo com esta, ou liberando-se dela, e associando-se a outras cidades-polo 
importantes da região, pudemos constatar como que Itaituba, pelas características acima citadas de integração produtiva à lógica de acumulação de capital global, sob uma racionalidade neoliberal e financeirizada, está conectando-se às principais redes mundiais de mercadorias e capitais, ligando-se diretamente a grandes metrópoles mundiais, em especial a metrópole de São Paulo.

Mostraremos também como isso se deu segundo uma lógica na qual a racionalidade neoliberal passa a ser uma racionalidade de Estado, que assume o papel fundamental de promover as condições para que tais grandes empreendimentos se instalem.

Para iniciarmos, é importante entendermos o contexto geral dos desafios e oportunidades logísticas associados ao Arco Norte. Segundo os dados do United States Departament of Agriculture - USDA -, o Brasil foi, na safra de 2014/2015 o segundo maior produtor mundial de soja, atrás dos Estados Unidos, com cerca de $30 \%$ da produção mundial. No entanto, é o maior exportador, alcançando cerca de 40\% das exportações mundiais (MTPA, 2017, p. 24). Segundo o MTPA (2017, p. 15) em 2015 o Brasil exportou 70,8 milhões de toneladas de soja. No entanto, as perspectivas futuras são impressionantes.

conforme aponta o MAPA (2015), a produção de grãos deverá passar de 200,7 milhões de toneladas em 2014/15 para 259,7 milhões de toneladas em 2024/25. Em valores relativos representa um acréscimo de $29,4 \%$, porém, no limite superior da variação, a projeção de produção poderá ser de 301,3 milhões de toneladas, cuja variação seria de 50,1\%. (MTPA, 2017, p. 24)

Dessa forma, e imaginando que 0 adicional de soja produzido nos próximos 10 anos seja destinado quase que exclusivamente à exportação, devido à saturação e estagnação econômica do mercado doméstico, poderíamos dizer que esse adicional de 59 milhões de toneladas/safra deverão procurar novas rotas e portos de escoamento, representando um aumento de mais de $80 \%$ em relação ao volume exportado anteriormente. Portanto, para além do desafio logístico associado ao custo de transporte, muito caro pelo Sul e Sudeste, é evidente que, de fato, estamos falando de um gargalo logístico de grande monta. 
Do ponto de vista do custo, a título de exemplo, de acordo com o relatório da Região de Integração Tapajós (IDESP, 2014), atualmente, para escoar a safra agrícola de Sorriso, no médio norte do Estado do Mato Grosso até o porto de Santos (SP) em um trajeto rodoviário e ferroviário, o produtor rural tem o gasto de $\mathrm{R} \$ 227,15 /$ tonelada. Cálculos do Movimento PróLogística ${ }^{113}$ apontam que, por meio da hidrovia, direcionando a produção para o porto de Santarém (PA), o custo seria reduzido para $R \$ 60,12 /$ tonelada.

Diante disso, a partir da década de 2000, a pavimentação da BR-163 é vista como alternativa para a criação de rotas alternativas de escoamento da produção de soja do cerrado, o que leva a uma articulação de atores econômicos participantes do processo de produção agrícola com vistas a viabilizar as obras necessárias para a pavimentação desta rodovia, a CuiabáSantarém. Dentre as possibilidades aventadas naquele momento, houve a proposta de viabilização da pavimentação da BR-163 por meio da iniciativa do setor privado, interessado na resolução do problema de infraestrutura, por meio de um instrumento de Parceria Público-Privada (PPP), no qual as empresas ligadas à produção de soja assumiriam os custos das obras na rodovia. (IDESP, 2014)

Outra obra considerada estratégica para o setor produtivo é a hidrovia Tapajós-Teles Pires, que poderá favorecer o escoamento da produção agrícola e também a geração de renda em diferentes setores, com justificativas econômicas e geopolíticas amplas e diferenciadas. Como apontam Correa e Ramos (2010), a ineficácia do transporte da soja produzida no Centro-Oeste do Brasil reside na escolha do modal rodoviário como unimodal, ao passo que a conexão multimodal (rodo-ferroviário ou rodo-hidroviário) para interligar a origem e o destino das cargas seria a escolha mais acertada (2010, p. 450). Vale notar, ainda, que, no que diz respeito às perdas atualmente geradas pelo uso incorreto de modais para longas distâncias no Mato Grosso, são calculadas em aproximadamente dois bilhões de reais (IDESP, 2014), o que tem levado à pressão, por parte dos produtores, de investimentos para realização dessas obras. 
Atualmente, e como alternativa mais viável, os investimentos preveem a utilização da parte já navegável do baixo Tapajós, integrando, via Estações de Transbordo de Carga, a intermodalidade com a BR-163 no seu encontro com o rio na região de Itaituba. Nesse trecho está prevista (ou já concluída) a construção de oito portos na margem direita do Tapajós, em frente a Itaituba. Dentre eles: a Estação de Transbordo de Carga / ETC Itaituba, empreendimento da Companhia Norte de Navegação e Portos (CIANPORT); a Estação de Transbordo de Carga / ETC Miritituba e a Estação de Transbordo de Carga HBSA Tapajós e a Estação de Transbordo de Cargas ETC Cargill. A operação desses portos tornará desnecessário percorrer os $2.300 \mathrm{~km}$ de estradas que separam a região Centro-Oeste dos portos do Sul do Brasil (Paranaguá/PR e Santos/SP).

Sobre cada um desses portos, temos que a Estação de Transbordo de Carga / ETC Itaituba, - empreendimento da Companhia Norte de Navegação e Portos (CIANPORT) - fará o transporte de cargas pela hidrovia TapajósAmazonas até os terminais portuários de Santana, no Amapá. Já as ETCs HBSA Tapajós e HBSA Miritituba serão locais dedicados à movimentação de grandes volumes de grãos e farelos trazidos de zonas produtoras norte-matogrossenses, transportados desse ponto até o Terminal de Uso Privativo Misto de Vila do Conde, em Barcarena-PA. Por sua vez, a Estação de Transbordo da CARGILL foi projetada para realizar operações portuárias e de transporte de cargas na região de influência da BR-163. Dessa maneira, a carga seguirá pela hidrovia Tapajós até o terminal próprio da Cargill em Santarém-PA.

Em janeiro de 2017 foram feitas duas visitas à Secretaria de Meio Ambiente e Sustentabilidade do Estado do Pará para levantamento dos dados acerca dos empreendimentos que estão em processo de licenciamento na região de Itaituba. Foram levantados 18 empreendimentos nos municípios de Itaituba, Rurópolis e Santarém. Ao todo, somam cerca de $\mathrm{R} \$ 4,5$ bilhões em investimentos, seja em estações de transbordo de carga (ETC), seja em terminais de uso privado (TUP).

Sob a perspectiva da etapa de licenciamento, que divide os empreendimentos por tipo de impacto que já estariam causando no território, temos que 6 deles, ou 38\% do total de investimentos previstos, já estão em 
fase de Licença de Implantação ou de Operação - Etapa 4; outros 6 empreendimentos, que contam com $36 \%$ dos investimentos previstos, ainda estão em fase de estudos de impacto ambiental (EIA) - Etapa 3; 5 deles ainda estão em fase de carta consulta - Etapa 1, indicando $21 \%$ dos valores previstos (apesar de, nessa etapa, os valores não serem muito precisos) e apenas um, com $5 \%$ do total de investimentos, ainda em fase de Licença Prévia - Etapa 2, conforme Gráfico 3 abaixo:

\section{Gráfico 3 - Distribuição dos investimentos previstos por etapa do processo de licenciamento ambiental}

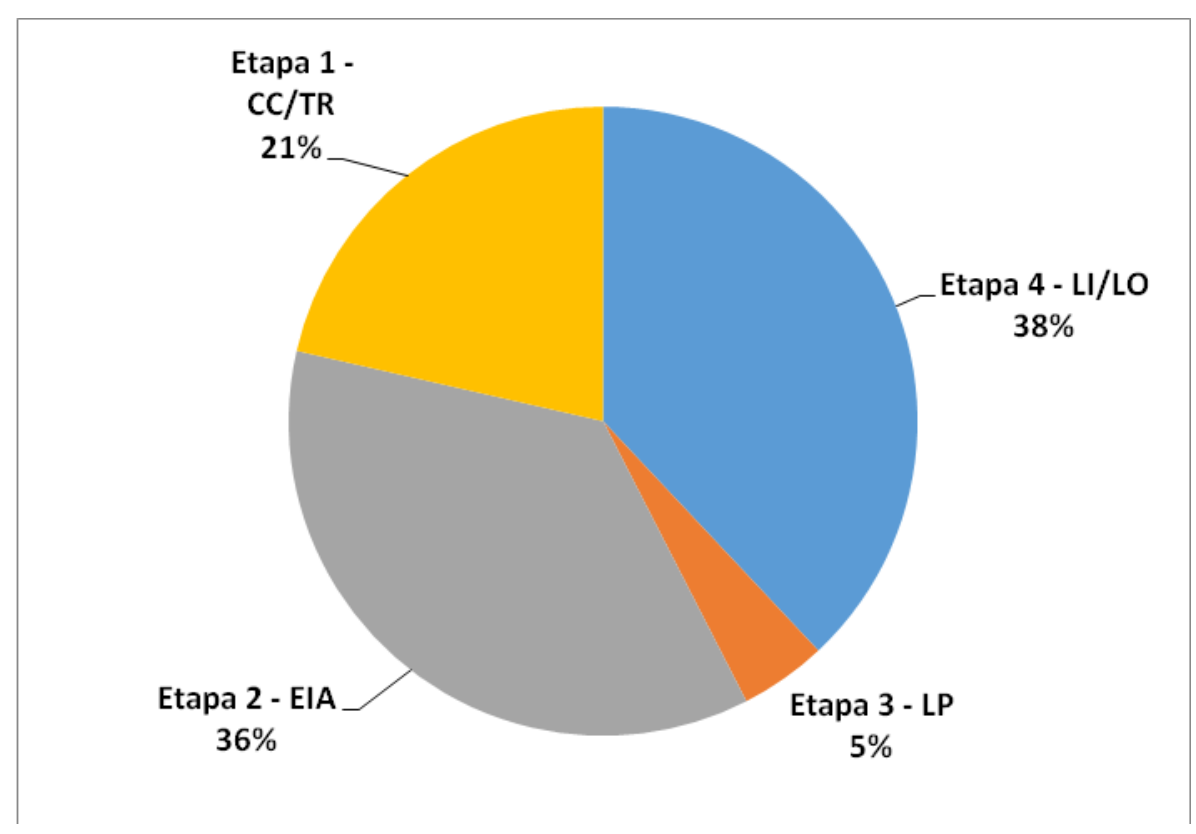

Fonte: Secretaria de Meio Ambiente e Sustentabilidade do Pará - elaboração própria

Importante também apontar (Tabela 4) que, dentre esses 18 novos investimentos (alguns já em operação), cerca de $75 \%$ ( $R \$ 3,5$ bilhões) do valor total a ser investido se concentrarão em Itaituba e Rurópolis, e apenas 16,5\% em Santarém, indicando a forte capacidade que, hoje, esses dois municípios têm de concentrar esse tipo de investimento, o que se deve, sobretudo, ao fato de o porto de Santarém já ser um porto consolidado, com dificuldades tanto locacionais quando de licenciamento ambiental para expansão. 
Tabela 4 - Participação dos investimentos previstos por município

\begin{tabular}{lr} 
Município & \% dos investimentos \\
Itaituba & $45,59 \%$ \\
Rurópolis & $29,37 \%$ \\
Santarém & $16,47 \%$ \\
Em estudo & $8,56 \%$ \\
\hline \hline Total Geral & $\mathbf{1 0 0 , 0 0 \%}$
\end{tabular}

Fonte: Secretaria de Meio Ambiente e Sustentabilidade do Pará - elaboração própria

Esse montante de investimentos previstos para esses municípios (Itaituba e Rurópolis) corresponde a cerca de 1,9 vezes o Produto Interno Bruto (PIB) desses 2 municípios para 2016, configurando-se, portanto, como um conjunto de investimentos capazes de promover profundas mudanças na região ao contribuírem para a estruturação do Corredor Logístico do Tapajós.

Para compreendermos essas mudanças, vamos, a seguir, apresentar o contexto territorial de inserção desses investimentos em uma cadeia logística global que, grosso modo, insere-se conforme indicado no mapa abaixo, integrando os mercados da Europa e da China, mobilizando o principal sistema portuário do Estado do Pará: 
Mapa 3 - Rotas de exportação de grãos a partir do baixo Tapajós

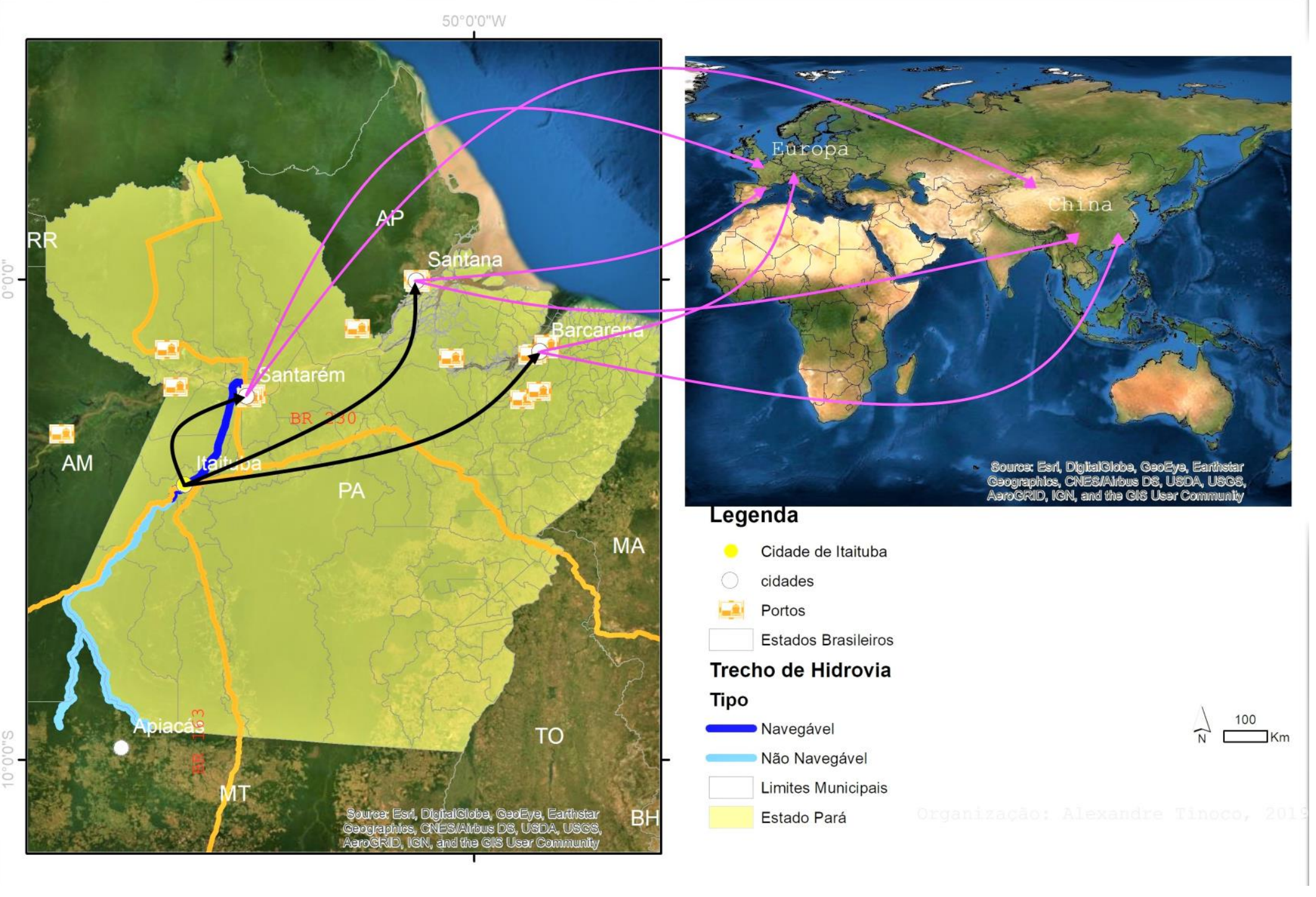




\subsubsection{A infraestrutura das cadeias de valor globais}

Como já adiantado, o Corredor Logístico do Tapajós faz parte do conjunto de corredores estratégicos de desenvolvimento constituintes do chamado Arco Norte, objeto do planejamento do Ministério dos Transportes, Portos e Aviação Civil (MTPA) ${ }^{114}$, visando "dotar o país de um sistema de transportes adequado, confortável, integrado, seguro, eficiente, acessível e com o menor custo possível". (MTPA, 2017, p. 10)

Segundo a definição do próprio MTPA, Corredores Estratégicos de Desenvolvimento devem ser entendidos como lugares ou eixos indutores de desenvolvimento "por meio de investimentos e da constituição de mercados produtores e consumidores". (MTPA, 2017, p. 13)

A importância do caráter logístico desses corredores se deve ao fato de que :

Esse sistema é composto de rotas modais e multimodais que viabilizam o transporte de cargas produzidas em sua área de influência. Usualmente, desde 1971, vem sendo denominado esse conjunto de rotas de transportes, com suas facilidades, de corredor de transporte, pois para ele convergem as movimentações ou fluxos de cargas que ali se processam ou entram e saem de sua área de influência. (MTPA, 2017, p. 13)

Em um mundo conectado e globalizado, onde as cadeias produtivas se estruturam em nível mundial, a definição de logística enquanto o elemento que permite o fluir é importante para compreendermos a forma com que se opera a territorialização do capital. Assim, Castillo e Frederico (2010), apoiando-se em Arroyo $(2001,2005)$, postulam que logística deva ser entendida como

o conjunto de competências infraestruturais (transportes, armazéns, terminais multimodais, portos secos, centros de distribuição etc.), institucionais (normas, contratos de concessão, parcerias público-privadas, agências reguladoras setoriais, tributação etc.) e operacionais (conhecimento especializado detido por prestadores de serviços ou operadores logísticos) que, reunidas num subespaço, podem conferir fluidez. (CASTILLO; FREDERICO, 2010, p. 21) 
Desta forma, os elementos viabilizadores da logística devem ser entendidos como a essência dos fluxos, sejam eles materiais ou imateriais, de pessoas, mercadorias ou capitais. O grau de fluidez (geralmente expresso em custo ou tempo) passa a ser uma característica diferenciadora do espaço, capaz de permitir, ou não, a conexão de lugares (fixos) à rede de fluxos.

\subsubsection{A constituição do Arco Norte}

O Arco Norte é constituído de três grandes corredores logísticos, que articulam diferentes modalidades de transporte. O Corredor Noroeste, associado ao Rio Madeira; o Corredor Centro-Norte, do Complexo Logístico do Tapajós e; o Corredor Nordeste, via utilização do Rio Tocantins. Constitui-se de um conjunto de iniciativas públicas e privadas que buscam articular toda a logística do Norte do Brasil visando a maior fluidez das exportações brasileiras, sobretudo de grãos. Segundo Menezes (2017) a constituição do Arco Norte se deu em cinco fases:

- Primeira fase: ocupação da Amazônia (1970-1980) Transamazônica;

- Segunda fase: Corredor Noroeste: HERMASA (1994-1997);

- Terceira fase: Corredor Noroeste: CARGILL (1999-2003);

- Quarta fase: Corredor Centro-Norte: BUNGE (TERFRON) (20042014) - BR 163;

- Fase atual: Corredor Centro-Norte e Nordeste: Consolidação do Arco Norte (2014-2020).

O Corredor Noroeste, estabelecido desde 1995 e já bem consolidado, possui duas rotas. Ambas se utilizam da Rodovia BR-364 que liga Vilhena a Porto Velho e, em seguida, via o porto de Porto Velho, recorre-se à Hidrovia do Rio Madeira quando, enfim, ou vão até o porto de Itacoatiara ou para o Porto de Santarém. É um corredor que não apresenta mais um grande potencial de expansão.

Por sua vez, o Corredor Nordeste, em processo de consolidação e que, portanto, possui muitas alternativas ainda em estudos, está sendo constituído por seis rotas diferentes. Uma rota de escoamento via Porto de São Luis se utiliza da BR-158 e das rodovias estaduais PA-284, TO-336 e TO-335 até o 
Terminal Ferroviário de Colinas do Tocantins, de onde a Ferrovia Norte-Sul faz o deslocamento até à Ferrovia dos Carajás.

As cinco outras rotas fazem, ou farão, o escoamento via Porto da Vila do Conde. Seja, atualmente, por via rodoviária pelas BR-158 e BR-155 e pelas rodovias estaduais PA-150, PA-151 e PA-483, seja, futuramente, utilizando-se da futura Hidrovia do Tocantins, da futura Ferrovia Paraense ou de futuras rodovias estaduais do Tocantins e da Ferrovia Norte-Sul.

O Corredor Centro-Norte, por sua vez, que cruza o baixo Tapajós, cria a possibilidade de quatro rotas de escoamento. Duas rotas via Porto de Santarém, uma utilizando-se apenas do modal rodoviário via BR-163 de Sinop até Miritituba e depois a BR-230 ou a continuidade da BR-163 de Miritituba até Santarém. A outra, mais ágil, se utilizaria das Estações de Transbordo de Carga em Miritituba para levar a carga até o Porto de Santarém.

Essas mesmas ETCs poderiam ser utilizadas para levar carga até o Porto de Santana, ao conectar a Hidrovia do Tapajós com a do Amazonas ou até o Porto da Vila do Conde, alcançando a futura Hidrovia do Tocantins através da passagem pelos estreitos da llha de Marajó.

Para a viabilização dessas quatro rotas muitos investimentos já estão ocorrendo, mas muitos outros ainda precisam ocorrer. Nos planos governamentais ainda será necessário viabilizar as concessões da rodovia BR163 para que seja feito seu asfaltamento e da Ferrovia Ferrogrão, ligando Lucas do Rio Verde, no Mato Grosso, a Itaituba (que acrescentaria ainda mais um modal às rotas apresentadas anteriormente). Segundo Menezes (2017, p. 50), o Corredor Centro-Norte é uma alternativa logística que "se concretizadas as iniciativas públicas e privadas em desenvolvimento, tenderá a se tornar o mais intenso e competitivo corredor de exportação de agrogranéis do Brasil", podendo chegar a escoar 32 milhões de toneladas de grãos, bem acima de qualquer outra alternativa logística do Arco Norte, conforme Figura 4 abaixo. 
Figura 4 - Capacidade de escoamento de grãos pelo Arco Norte.

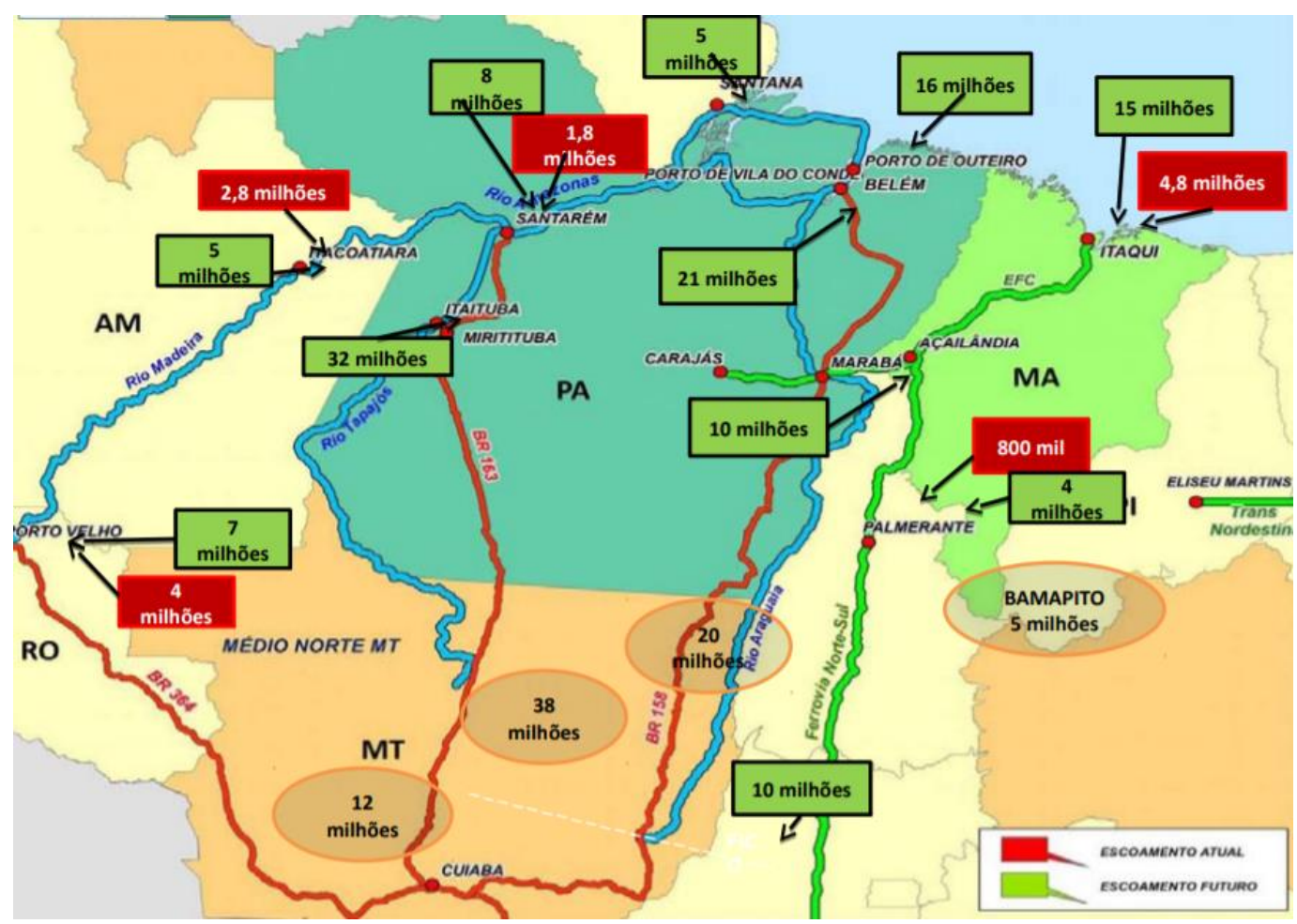

Fonte: Menezes (2017)

Das alternativas e potenciais apresentados acima ficam patentes duas características importantes para compreendermos o caráter contemporâneo dos processos de formação dos espaços regionais no baixo Tapajós. Primeiro, uma lógica de investimentos em logística que hoje são integradas com as cadeias produtivas globais. Diferentemente de alguns grandes projetos do final do século XX que visavam desbravar a fronteira de ocupação do país, viabilizando acesso, os grandes empreendimentos do século XXI são investimentos diretos da cadeia produtiva global, integrando territórios de produção, circulação e consumo de mercadorias em escala mundial.

A segunda característica é a atuação conjugada do Poder Público com a iniciativa privada em que fica claro que, para ser possível o investimento privado nesse sistema de logística, o Estado tem um conjunto grande de obrigações a cumprir, como bem nos lembra Rodrigues (2018, p. 210)

O Arco Norte é um projeto do Estado brasileiro em sinergia com setores empresariais do agronegócio. Nesse projeto, o Estado, vem assegurar e organizar as condições necessárias para instalações portuárias e logísticas: 1) abertura e pavimentação de estradas, construção de ferrovias e hidrovias; 2) financiamento público a obras privadas; 3) incentivos fiscais e energéticos; 4) dispositivos jurídicos que possibilitem 
ampliação da chamada segurança jurídica, mais direitos e concessões ao setor empresarial; 5) viabilidade do licenciamento ambiental; 6) qualificação de mão-de-obra; 7) Elaboração de estudos e pesquisas que possam otimizar a movimentação de mercadorias.

Desta forma, diferentemente da maneira estatalmente dirigida dos investimentos que marcaram a época keynesiano-fordista, a racionalidade neoliberal de um Estado viabilizador de condições necessárias para a livre atuação do setor privado, inclusive com a privatização de alguns serviços e infraestruturas, está bem presente no desenvolvimento atual de todo o Arco Norte, especialmente em seu Corredor Centro-Norte e na importância do Corredor Logístico do Tapajós.

Para Martner-Peyrelongue (2014, p. 107), esses novos portos (e suas extensões como as ETCs), como elementos de logística de um mundo marcado pela intensificação dos fluxos, podem ser chamados de "portos da globalização". Essa espécie de porto pode ser caracterizada como sendo

o porto da integração das redes, é o porto dos movimentos rápidos, da aceleração do tempo, da diferença do tempo lento do porto do protecionismo.

A distinção entre "porto do protecionismo" e "porto da globalização" é bastante significativa da passagem do mundo urbano-fordista para 0 metropolitano-neoliberal e de como esse tipo de infraestrutura opera na produção dos espaços regionais. Os primeiros, historicamente associados a grandes investimentos (e gestão) públicos, "eram concebidos como componentes logísticos, como rodovias, ferrovias, hidrovias e aeroportos, e não por serem eixos de articulação nacional-global, de fluxos materiais e imateriais intra/extraescalar" (RODRIGUES, 2018, p. 205), como lugares de arrecadação de tributos (que financiam o Estado), onde se operam os controles de volumes exportados e importados pelo país e que, com isso, se transformam em elementos ativos nas políticas de incentivo à atividade econômica nacional, são elementos importantes de uma forma de atuação de Estado característica do modelo fordista-keynesiano de desenvolvimento. Do ponto de vista espacial, é ao redor desse portos ou nas proximidades deles, que fazem a fronteira com 0 
que é externo, que se estruturam as grandes cidades e muitas de nossas regiões metropolitanas.

Por sua vez, o "porto da globalização", resultante dos sistemas intermodais e multimodais de transporte e de informação, diferentemente da época urbano-industrial,

[...] donde el puerto resaltó su condición de borde, de valla de contención frente al exterior, ahora se revaloriza como espacio vinculante e interactivo, principalmente entre el ámbito local y el global [...] el centro de procesamiento, distribución e integración de cadenas productivas fragmentadas internacionalmente. ${ }^{115}$ (MARTNER PEYRELONGUE, 1999, p. 7)

Desta forma, na época metropolitano-neoliberal "os portos passam a serem gestores e articuladores, no tempo e no espaço, de fluxos que abastecem processos territorialmente dispersos e fragmentados." (RODRIGUES, 2018, p. 205), exercendo o importante papel de articuladores dos fluxos internacionais tão marcantes do processo de globalização. Ou seja, os processos de importação e exportação de mercadorias no mundo metropolitano-financeiro não se resumem a trocas comerciais entre países. Para além disso, se constituem como fluxos necessários para o processo ampliado de acumulação de capital ao integrar cadeias produtivas espacialmente fragmentadas. Neste processo, colocam lugares em concorrência, inserindo alguns nessas cadeias globais e excluindo outros.

Se, de um lado, o "porto da globalização" integra cadeias produtivas a partir de territórios fragmentados, poderíamos dizer que o "porto do protecionismo" integrava os territórios nacionais, ao fragmentar as cadeias internacionais por meio de medidas protecionistas e barreiras à entrada. De fato, isso gera arranjos espaciais bastante diferentes e demanda formas distintas de ação estatal.

Essa mudança na forma da ação estatal pode ter seu marco identificado no início dos anos 1990, em pleno processo de abertura comercial brasileira,

115 - "onde o porto destacou seu status como uma borda, cerca de contenção versus o exterior, agora é revalorizado como um espaço vinculativo e interativo, principalmente entre o local e o global [...] o centro de processamento, distribuição e integração de cadeias de produção internacionalmente fragmentadas 
primeiro com o fim do órgão governamental responsável pela gestão dos portos nacionais, a Empresa de Portos do Brasil S.A (PORTOBRÁS), em 1990, por meio do Programa Nacional de Desestatização para, em seguida, já no Governo Itamar Franco, com a lei 8630/1993, que redesenhou o marco regulatório do setor portuário. (GOULARTI FILHO, 2007; MONIÉ, 2011)

Podendo ser compreendido como bastião do neoliberalismo no setor portuário, esse redesenho visava implantar, nesse setor, a racionalidade neoliberal que discutimos anteriormente, uma vez

que buscavam promover uma reengenharia institucional e legal para ampliar a competitividade dos ambientes portuários, ao estimular a atuação concorrencial entre os portos (interportos) e no interior dos mesmos (intraportos)." (RODRIGUES, 2018, p. 205)

No entanto, por mais que esses dois momentos expressem um afastamento do Estado como ator nessa área de logística, também permitiram novas bases de sua atuação.

O Estado brasileiro, para chegar até a compreensão, supostamente mais avançada de sociedade e de Estado, do qual os portos são gestores e articuladores de fluxos, precisou efetuar, sobretudo, a partir do início da década de 1990, políticas públicas para área portuária de forma um pouco mais intensa e continuada. (RODRIGUES, 2018, p. 205)

No Governo Fernando Henrique Cardoso, avaliava-se que esse redesenho institucional bastaria para trazer previsibilidade para os agentes econômicos que, assim, estariam livres para atuar de forma a promover 0 desenvolvimento do setor portuário no Brasil, ao buscarem estabelecer-se nesse mercado. No entanto, sabemos que as coisas não funcionam muito bem assim e, de fato, uma atuação do Estado ainda mais alinhada com a racionalidade neoliberal (no sentido tratado por Dardot e Laval (2010b) seria ainda necessária. Dessa forma, no segundo Governo Lula,

O Estado brasileiro, a partir de 2007, vem planejando e executando políticas públicas de infraestrutura de maneira continuada e de longo prazo, sobretudo, na área portuária, por meio de financiamento público, incentivos fiscais, concessões de terras e autorizações para construção de portos privados em diversas regiões do Brasil [...] começou a ser constituída, pelo menos de forma mais agressiva, uma visão estratégica 
nacional orientadora do planejamento no país, e no seio do aparelho indutor do processo produtivo brasileiro, do Estado brasileiro. (RODRIGUES, 2018, p. 204)

Depois de anos de desregulamentação do setor, sem que isso tenha se convertido em investimentos privados espontâneos, o Estado assume o papel de grande articulador, viabilizando inclusive com parte dos investimentos, a partir de uma

visão estratégica nacional [que] passou a ser exposta em uma série de programas e políticas horizontais ${ }^{116}$, na maioria dos investimentos e em discursos políticos, como forma de superar - chamado custo-Brasil, a multimodalidade. (RODRIGUES, 2018, p. 207)

E não foi pouco investimento. Entre 2007 e 2014, só o PAC, segundo Rodrigues (2018, p. 207), "injetou, na área de infraestrutura, particularmente de infraestrutura portuária e de transporte, rodoviário, ferroviário, hidroviário e aeroviário, 132,3 bilhões de reais". O PIL, por sua vez, previa um investimento, entre 2016 e 2019, de mais " $R \$ 54,2$ bilhões, destinados a estimular os arrendamentos de áreas dentro dos portos e a construção e ampliação de Terminais de Uso Privativo - TUPs". Por último, o II PNLP destinou outros R $\$$ 51,28 bilhões, entre projetos de novos arrendamentos, novas instalações privadas e investimentos em dragagens. (RODRIGUES, 2018, p. 208)

Desta forma, no cenário nacional, nos últimos 12 anos, avaliou-se ou investiu-se um montante de cerca de $R \$ 235$ bilhões para infraestrutura logística, em especial portuária. Entre os projetos, encontram-se os necessários para viabilização do Arco Norte que, para além de um simples conjunto de projetos de engenharia, e associados às lógicas territoriais de atuação das empresas da cadeia global as soja, evidenciam que a

ampliación territorial del circuito se produce como resultado de un conjunto de condiciones técnicas y políticas, o sea gracias a la creación de una alta productividad espacial para el cultivo de la soja. En efecto, al stock de recursos naturales preexistentes

116 - Dentre eles, o Programa de Aceleração do Crescimento (PAC), em 2007; a Política de Desenvolvimento Produtivo (PDP), em 2007; a Política Nacional de Logística e Transporte, em 2007; Plano Nacional de Viação, em 2008; a Política Nacional de Transporte Hidroviário (revisada em 2010); a Política Nacional de Aviação Civil, em 2009; e, o Plano Hidroviário Estratégico, em 2010. (CASTRO, 2012) 
(topografía, temperatura, distribución de lluvias y días de radiación solar), se van agregando otros factores. Por un lado, se introducen diferentes prácticas, tales como el uso de fertilizantes, los sistemas de irrigación, la utilización de máquinas e implementos modernos y, sobre todo, el uso de semillas mejoradas y de otros insumos (herbicidas, funguicidas e insecticidas). Por otro lado, los gobiernos estatales y federales organizan programas especiales de financiamiento, establecen sistemas de créditos, incentivos fiscales $y$ subsidios. ${ }^{117}$ (ARROYO, 2014, p. 164-165)

Essa articulação público-privada que se observa de forma generalizada no Brasil se opera também especificamente no Arco Norte. Nisso, o posicionamento do então Ministro da Integração Nacional, Helder Barbalho, quando de seu discurso no 1ํFórum de debates: a logística voltada para 0 Arco Norte, realizado em Santarém/PA no dia 24 de junho de 2016, demonstra bem o que seria o papel do Estado neoliberal neste momento.

O mercado internacional precisa sentir segurança para aplicar seu capital e executar o que planeja. Além disso, o Brasil precisa dialogar e entender que sua regulação não pode ser excessiva. É necessário um ambiente mais desburocratizado em nosso país para incentivar o desenvolvimento. (SOARES, 2018, p. 213)

De forma ampla, a estruturação do Arco Norte é tratada, nessa interface entre interesse público e interesse privado, com o objetivo de contribuir para estruturar a cadeia global de grãos, "aproximando o mercado de grãos ao mercado chinês, isto é, estimulando a competitividade do agronegócio no mercado internacional e alimentando lucros de bancos, fundos de investimento e multinacionais". (SOARES, 2018, p. 213)

Importante também chamar atenção ao fato de que essa imbrincada relação público-privada de viabilização dessa alternativa extremamente rentável de logística, mais do que um esforço exclusivo da esfera Federal, tem sido capaz de articular todos os níveis da Federação, passando pela

117 - [a] ampliação territorial do circuito se produz como resultado de um conjunto de condições técnicas e políticas, ou seja, graças à criação de uma alta produtividade espacial para o cultivo da soja. Com efeito, ao estoque de recursos naturais preexistentes (topografia, temperatura, distribuição de chuvas e dias de radiação solar) vão-se agregando outros fatores. De um lado, introduzem-se diferentes práticas, tais como o uso de fertilizantes, os sistemas de irrigação, a utilização de máquinas e implementos modernos e, sobretudo, o uso de sementes melhoradas e de outros insumos (herbicidas, fungicidas e inseticidas). Por outro lado, os governos estatais e federais organizam programas especiais de financiamento, estabelecem sistemas de créditos, incentivos fiscais e subsídios. 
elaboração de políticas na esfera federal, inserindo o Arco Norte nos Planos do Estado do Pará, por exemplo, e chegando aos Planos Diretores Municipais. Segundo a leitura de Rodrigues (2018, p. 216):

A presença do "rei da soja" no MAPA 118 sinaliza certo consenso de commodities sobre o projeto Arco Norte. Além da sinergia entre as esferas federal, estadual e municipal no estado do Pará. $\mathrm{Na}$ escala estadual, essa construção de consenso, efetuada via o plano PARÁ 2030 e na escala municipal, com a atualização dos planos diretores de Itaituba e Barcarena, em 2015 e 2016, respectivamente.

Como resultado desse interesse e esforço conjunto,

A participação do Arco Norte, que há 5 anos, segundo dados do Ministério da Agricultura, escoava $8 \%$ do total de soja e milho destinado ao mercado internacional, já alcança $20 \%$ dos embarques totais do País. (CÂMARA DOS DEPUTADOS, 2016, p. 145)

Volume esse que, segundo a ANTAQ, já chegava, em 2015, a 30 milhões de toneladas de grãos (soja e milho) por ano. De acordo com as estimativas do MAPA (2016) de uma economia de U\$ 50 por tonelada, representam uma captura extra de cerca de U\$ 1,5 bilhão por ano devido à diminuição dos custos de transporte, a ser apropriado pelas empresas que operam essa logística e que irão remunerar seus acionistas.

Em um esforço de compreender a relação entre a dinâmica regional dos espaços agrícolas e a globalização, Castillo e Frederico (2010, p. 24) vão na mesma linha de compreensão, de que essa conjunção de interesses entre público e privado visava a inserção de "forma competitiva nos mercados internacionais".

No entanto, essa inserção competitiva nos mercados não é questão "apenas" do comércio de mercadorias. Esse movimento está inserido, de forma mais ampla, numa estratégia de inserção competitiva "nos circuitos produtivos e financeiros globais, via aumento de exportações de commodities", que na realidade são estratégias de "inserção no processo/circuitos monopolísticos- 
financeiro internacionais de acumulação-ampliação do capital". (RODRIGUES, 2018, p. 203)

Lembrando que estamos vivenciando uma era organizada por fluxos e que um dos critérios de competitividade é justamente a fluidez desses fluxos, o processo que acabamos de descrever, de alinhamento de interesses públicoprivados visando a inserção em circuitos de acumulação ampliada do capital, visou especificamente

criar estratégias para reduzir o tempo de armazenamento de mercadorias, promover a maior fluidez e o aumento da integração entre os elementos do sistema complexo de produção mundial, de relações e redes informacionais/relacionais e financeiras. Consistindo, assim, na formação de um espaço global de fluxos de mercadorias. (RODRIGUES, 2018, p. 203)

O resultado disso é o relativo descolamento que as regiões que se inserem nesses circuitos passam a ter em relação às antigas hierarquias de lugares onde estavam inseridas, para passarem a fazer parte da rede mundial de cidades que estruturam esses circuitos de acumulação ampliada do capital.

Uma vez entendido o papel do Estado no processo de constituição de tais estratégias, é importante agora compreendermos como o setor privado atua nessa relação e nessa cadeia global em específico.

A cadeia global de grãos é fortemente estruturada pelas grandes companhias de trading que dominam o mercado mundial de grãos. As empresas do chamado grupo ABCD, ADM, Bunge, Cargill e Louis Dreyfus Company, passaram, desde o final do século passado, por processos de verticalização e hoje atuam "além da compra, armazenamento, processamento (com produção de óleo e farelo) e venda e exportação de soja - na produção e venda de fertilizantes e adubos, oferta de financiamentos, assessoria técnica". (FIORAVANTI, 2019, p. 189)

Além da verticalização, que internaliza todas as etapas do processo, essas grandes empresas controlam processos indiretamente relacionados à sua cadeia produtiva e, assim,

Essas grandes empresas do agronegócio dominam, cada vez mais, o beneficiamento (classificação, limpeza, secagem), a 
assistência técnica, o processamento agroindustrial, o mercado de fertilizantes, o mercado de sementes, o armazenamento, o financiamento da produção, a comercialização e a exportação. Controlam indústrias processadoras, armazéns e silos, empresas de colonização, empresas de comercialização de produtos agrícolas e seus derivados; atuam no transporte rodoviário, ferroviário, fluvial e marítimo, possuem terminais em portos fluviais e marítimos, centros de distribuição, escritórios exportadores, postos avançados de compra de grãos; fornecem crédito de custeio e investimento, prestam assessoria técnica a produtores conveniados, estabelecem parcerias com empresas de logística entre outras ações que variam segundo as especificidades do circuito de cada produto. (CASTILLO; FREDERICO, 2010, p. 24)

Esse conjunto de novas estratégias utilizadas por estas empresas para controlarem e monopolizarem o comércio de grãos tem na terra um elemento importante, e que, agora, passar a ter uma nova função,

além do seu tradicional papel na obtenção de empréstimos e
na produção agrícola, transforma-se em um ativo financeiro de
grandes empresas [...] ancorando-se na produção de
commodities, nas bolsas de mercadorias e de futuro.
(FIORAVANTI, 2019, p. 188)

Essa nova função da terra acaba por se ajustar a diferentes estratégias adotadas por essas tradings. Segundo Oliveira A. (2015, p. 241),

\begin{abstract}
essas empresas monopolistas mundiais (global monopoly companies) articulam-se através de dois processos monopolistas territoriais no comando da produção agropecuária e florestal mundial: a territorialização dos monopólios (territorialization of monopolies) e a monopolização do território (monopolization of territory).
\end{abstract}

Tradicionalmente, a agricultura capitalista se baseia na propriedade da terra como elemento básico para produção agrícola. Como vimos, essa tem também um papel importante para obtenção de crédito. É por essa estratégia que, uma vez proprietários de terra, essas empresas podem usufruir das rendas oriundas da terra, como vimos anteriormente e, nessa economia globalizada e financeirizada, podem comercializar esses direitos no mercado financeiro, potencializando sua capacidade de financiamento e abrindo oportunidades para capital de terceiros (sobretudo de fundos de investimentos) participarem dos benefícios advindos da renda da terra. Desta forma, com a 
expansão e aquisição de novas terras (para as quais o mercado financeiro contribui),

a territorialização dos monopólios ocorre através do controle da propriedade privada da terra, do processo produtivo no campo e do processamento industrial da produção agropecuária e florestal. (OLIVEIRA, A., 2015, p. 242)

Por outro lado, as empresas podem adotar estratégias de monopolização dos territórios, que
se dá através das empresas de comercialização (trading companies) e/ou processamento industrial da produção agropecuária, que não produzem diretamente no campo, porém, controlam através de mecanismos de subordinação, a produção dos camponeses e dos capitalistas produtores do campo. (OLIVEIRA, A., 2015, p. 242)

Percebemos aqui a importância da propriedade da terra para os empreendimentos de logística, como são as ETCs. Podemos até entender as ETCs como o local de encontro dessas duas estratégias. A monopolização do território, a partir do qual se controla a apropriação de mais valia produzida no campo, é potencializada pela territorialização do monopólio da logística eficiente que a propriedade da terra das ETCs Ihes permite operar (da mesma forma que o silo de armazenamento). Desta forma, esse mix entre estas duas estratégias permite alavancar a magnitude da mais valia apropriada no processo de distribuição de mais valia, aumentando ainda mais o poder de monopólio e, consequentemente, de mercado destas grandes empresas.

É precisamente isso que está acontecendo no Corredor Logístico do Tapajós, no Arco Norte, o encontro dessas duas estratégias. E, nesse encontro, os processos de financeirização também possuem um lugar central. Ou seja, a estruturação de cadeias produtivas globalizadas, feita a partir de uma imbricada relação entre setor privado e Estado, é também um reflexo da financeirização dessas relações. Em conclusão, Rodrigues (2018, p. 220) estipula que,

a modernização, concessão e construção de terminais privados vão além da integração física nacional e internacional e defesa do território amazônico, inserem-se na lógica do aumento dos fluxos de mercadorias, a captura de capitais, a fluidez nas 
relações de trocas e a inserção ao processo de expansão do capitalismo financeirizado.

Isso porque

Esses complexos portuários graneleiros significariam, a expressão e resultado de territorialização de dinâmicas territoriais circunscritas à escala regional e com conexões aos circuitos globais financeiros, com a preponderância/protagonismo do Estado como agente territorial, mediador, regulador, jogador e organizador político do jogo. (RODRIGUES, 2018, p. 220)

Configurando-os como uma síntese bastante completa do mundo neoliberal em que vivemos e que tem atraído bastante atenção de novos investidores, como apontado por Aguiar (2017, p. 64) até mesmo dos chineses, grandes compradores de soja do Brasil, uma vez que

o aprofundamento da participação privada em toda a cadeia de transporte multimodal [...] intensifica a neoliberalização da agenda de investimentos em infraestrutura no país.

Esse processo de transformação pelo qual a região do baixo Tapajós vem passando, com forte presença da racionalidade neoliberal que pressupõe a conexão dessa região aos circuitos globais de produção e distribuição do valor, por meio de processos de produção globalizada e financeirização, sob uma lógica neoliberal de relacionamento entre Estado e iniciativa privada operou, entre outras coisas, a transformação de portos de protecionismo em portos da globalização. No final das contas, a resposta que buscamos dar com a estruturação de uma lógica metropolitano-financeira refere-se a um questionamento que também pode ser colocado da seguinte maneira:

What happens to a system in which ports, as nodes of material interchange, convert into elements of global investment strategies and thus become nodes of financial and virtual transactions (cf. Baird,(2013) on the role of private equity funds in port ownership). ${ }^{119}$ (MONIOS; WILMSMEIER, 2016, p. 249)

119 - O que acontece a um sistema no qual portos, como nós de intercâmbio material, convertem-se em elementos de estratégias de investimento global e assim se tornam nós de transações financeiras e transações virtuais? (Cf. Baird, (2013) sobre o papel de fundos privados de equidade na posse de portos). 


\subsubsection{A presença dos Grupos Econômicos}

As dezesseis Estações de Transbordo de Carga cujos licenciamentos ambientais estão atualmente sob acompanhamento da Secretaria de Meio Ambiente e Sustentabilidade do Estado do Pará, na região do baixo Tapajós, são elementos centrais nessa transformação dos portos do Pará e do Amapá em portos da globalização, como vimos acima. Ao todo, somam $R \$ 3,8$ bilhões de investimentos, alguns já realizados, outros em implantação e alguns ainda em estudo, conforme estágio do licenciamento ambiental apresentado no Gráfico 3.

Essas ETCs apresentam-se também como lugares de conexão entre os processos vistos anteriormente de territorialização de monopólios e de monopolização de territórios (OLIVEIRA, A., 2015). Com Isso, colocam-se como mais uma oportunidade de captura de mais-valia. No entanto, diferentemente da captura de mais-valia proveniente dos processos de subordinação financeira e de insumos típicos das tradings no caso da logística, o que garante a possibilidade de apropriação de mais-valia é a propriedade privada da terra onde a operação de transbordo se realizará, conectando modais distintos de transporte (rodo/ferroviário com o fluvial, no caso). Vale ressaltar que isso não é um processo novo.

El circuito espacial de producción de la soja está controlado por un número reducido de grupos económicos nacionales $y$ extranjeros que, la mayoría de las veces, también actúan en las actividades de logística y transporte asociadas al circuito. De ese modo, articulan bajo un mismo movimiento diversas instancias productivas, fortaleciendo la tendencia a un uso corporativo del territorio. ${ }^{120}$ (ARROYO, 2014, p. 169)

Como vimos (Tabela 4), Itaituba e Rurópolis receberão cerca de $75 \%$ do total desses investimentos. Dos $25 \%$ restantes, cerca de $16 \%$ estão destinados a empreendimentos no Município de Santarém e 9\% ainda em estudo.

Esse direcionamento expressivo para Itaituba e Rurópolis (que, na realidade, localiza-se no entorno do Distrito de Miritituba, em Itaituba), referente

120 - O circuito espacial de produção da soja está controlado por um número reduzido de grupos econômicos nacionais e estrangeiros que, na maioria das vezes, também atuam nas atividades de logística e transporte associadas ao circuito. Desse modo, articulam num mesmo movimento diversas instâncias produtivas, fortalecendo a tendência a um uso corporativo do território. 
a 11 dos 16 empreendimentos, por si só já expressa um relativo deslocamento de importância, no baixo Tapajós, de Santarém para Itaituba, com possíveis reflexos na hierarquia urbana existente entre elas e indicadas pela análise das REGICs que fizemos no item 1.3 desta tese.

No entanto, primeiramente, pela característica do tipo de empreendimento, de logística, de transbordo de modal de transporte, são investimentos com poucos encadeamentos para a frente e para trás, no sentido de Hirschman, conforme discutido no item 2.2 desta tese. Essa falta de encadeamento se deve ao baixo conteúdo de compras locais e de geração de empregos locais, referentes aos encadeamentos para trás; e, no sentido de encadeamentos para frente, pela baixa incorporação, no mercado local, dos serviços ou produtos provenientes dessa atividade. Com isso, esse tipo de investimento tem baixo potencial de alterar a posição de Itaituba na hierarquia da rede de cidades de Santarém.

Por outro lado, esses investimentos podem ser considerados vetores dos novos elementos de centralidade que discutimos anteriormente, levando para a região uma lógica de ocupação dos lugares do tipo metropolitanoneoliberal.

Já vimos que a estruturação do Arco Norte, do qual o Corredor Logístico do Tapajós faz parte, estrutura-se numa lógica de parceria e investimentos público-privados atrelados à racionalidade neoliberal. Falta-nos mostrar que os investimentos estão, eles também, inseridos nessa racionalidade, ou seja, estruturando as cadeias globais de produção de valor, de forma financeirizada.

Para tanto, optamos por estudar e compreender a titularidade e a origem do investimento dos dezesseis empreendimentos em andamento na região.

Pelo levantamento realizado, pudemos identificar o nome do investidor. A partir disso, efetuamos um levantamento acerca das participações acionárias nesses investimentos.

Além de altamente concentrado no entorno de Miritituba, pudemos verificar que apenas $8,5 \%$ dos investimentos são feitos por empresas locais (geralmente do próprio setor de logística), originárias da própria Amazônia, sejam elas públicas ou privadas. Por outro lado, mais de $51 \%$ são de origem 
internacional, com forte presença do grupo ABCD; e 37\% dos investimentos provêm de empresas sediadas, ou com histórico de fundação, no Estado de São Paulo (cidade de São Paulo e Campinas). Esses dados são bastante esclarecedores sobre o tipo de dinâmica de acumulação de capital que está se dando nessa região. Uma oportunidade gerada pela possibilidade de definição de novas frentes logísticas põe em disputa pelo uso da terra capitais distintos e de diferentes regiões. Seja do capital do próprio agronegócio da região e do Cerrado brasileiro, seja o capital internacional de produção e transporte de grãos, seja de capitais nacionais, sobretudo sediados em São Paulo, que buscam construir estratégias financeiras capazes de posicioná-los na disputa pela apropriação de mais-valia por meio da renda da terra existente naquele território, frente à perspectiva de obtenção de lucros advindos da localização privilegiada em termos de logística mundial de grãos.

Tabela 5 - Participação dos investimentos previstos por origem do capital

\begin{tabular}{lr} 
Origem do capital & \% dos investimentos \\
\hline Agronegócio & $2,98 \%$ \\
Internacional & $51,12 \%$ \\
Regional & $8,56 \%$ \\
São Paulo & $37,34 \%$ \\
\hline \hline Total Geral & $\mathbf{1 0 0 , 0 0 \%}$
\end{tabular}

Fonte: Secretaria de Meio Ambiente e Sustentabilidade do Pará - elaboração própria

Mas quem são, de fato, esses investidores? E de onde vem o recurso investido? Essas são as questões que procuramos responder ao destrinchar as participações societárias das empresas proprietárias desses 16 empreendimentos.

Para tanto, buscamos informação acerca da fundação e controle destas onze empresas (algumas têm mais de um empreendimento): Bunge; Hidrovias do Brasil S.A.; Cianort; Cargill, Embraps; Cevital; Ceagro; LDC; Transportes Bertolini; Companhia Docas do Pará e Odebrecht Transport.

Em relação aos dados de participação acionária das empresas, e para mantermos a relevância dos dados levantados, decidimos por limitar a informação para no máximo cinco acionistas. Com isso pudemos identificar a propriedade, setor de atuação e região e/ou cidade de origem do capital de 
$88 \%$ do total de investimentos. Isso se aplica especialmente à Bunge, que possui ações listadas na Bolsa de Nova lorque e os 5 maiores investidores institucionais correspondem a $39 \%$ de seu capital, o restante estando disperso ou em pequenos investidores institucionais ou nas mãos de pessoas físicas espalhadas pelo globo. No caso da empresa Hidrovias do Brasil, esse recorte deixou de fora apenas $2,9 \%$ de seu capital, com os restantes $97,1 \%$ nas mãos de apenas 5 investidores.

As quatro ETCs já em operação são as mais próximas da sede do Distrito de Miritituba. São da Bunge, Hidrovias do Brasil S.A., Cianort e Cargill. Juntas, somam cerca de $R \$ 1,5$ milhão de investimentos já realizados.

Figura 5 - Localização das ETCs existentes na margem direita do rio Tapajós, no Distrito de Miritituba (2019)

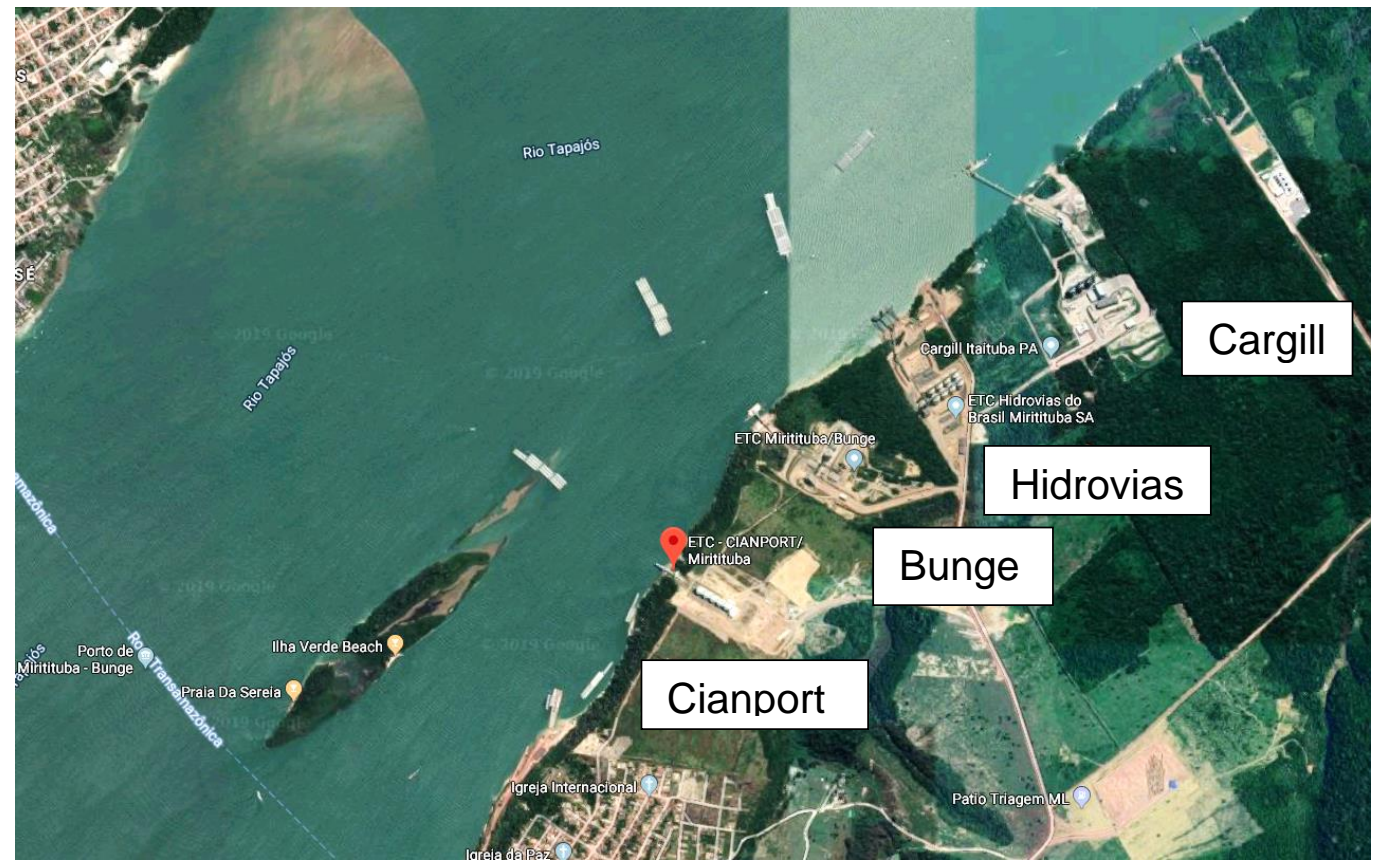

Fonte: Google Earth (2019)

\section{Bunge $^{121}$}

A Bunge do Brasil pertence à holding Bunge Limited, e tem sua sede em White Plains, Nova Iorque, nos Estados Unidos (EUA). Em 2016 faturou globalmente U\$ 42,6 bilhões e contava com 32 mil funcionários atuando em 40 países. Sendo uma empresa de origem familiar que surgiu em Amsterdam, Holanda, em 1818, decidiu-se por se lançar no mercado de capitais em 2001. 
Hoje, cerca de $80 \%$ de suas ações, negociadas na NYSE (Bolsa de Valores de Nova lorque), encontram-se nas mãos de 442 instituições financeiras, como grandes fundos de pensão e Hedgs Funds, sendo o maior deles o Price $T$. Rowe Associates, sediado em Baltimore, com cerca de $11,2 \%$ do total de ações. Os cinco maiores acionistas institucionais somam 39\%, conforme Gráfico 4 abaixo

\section{Gráfico 4 - Participação acionária na Bunge - julho de 2019}

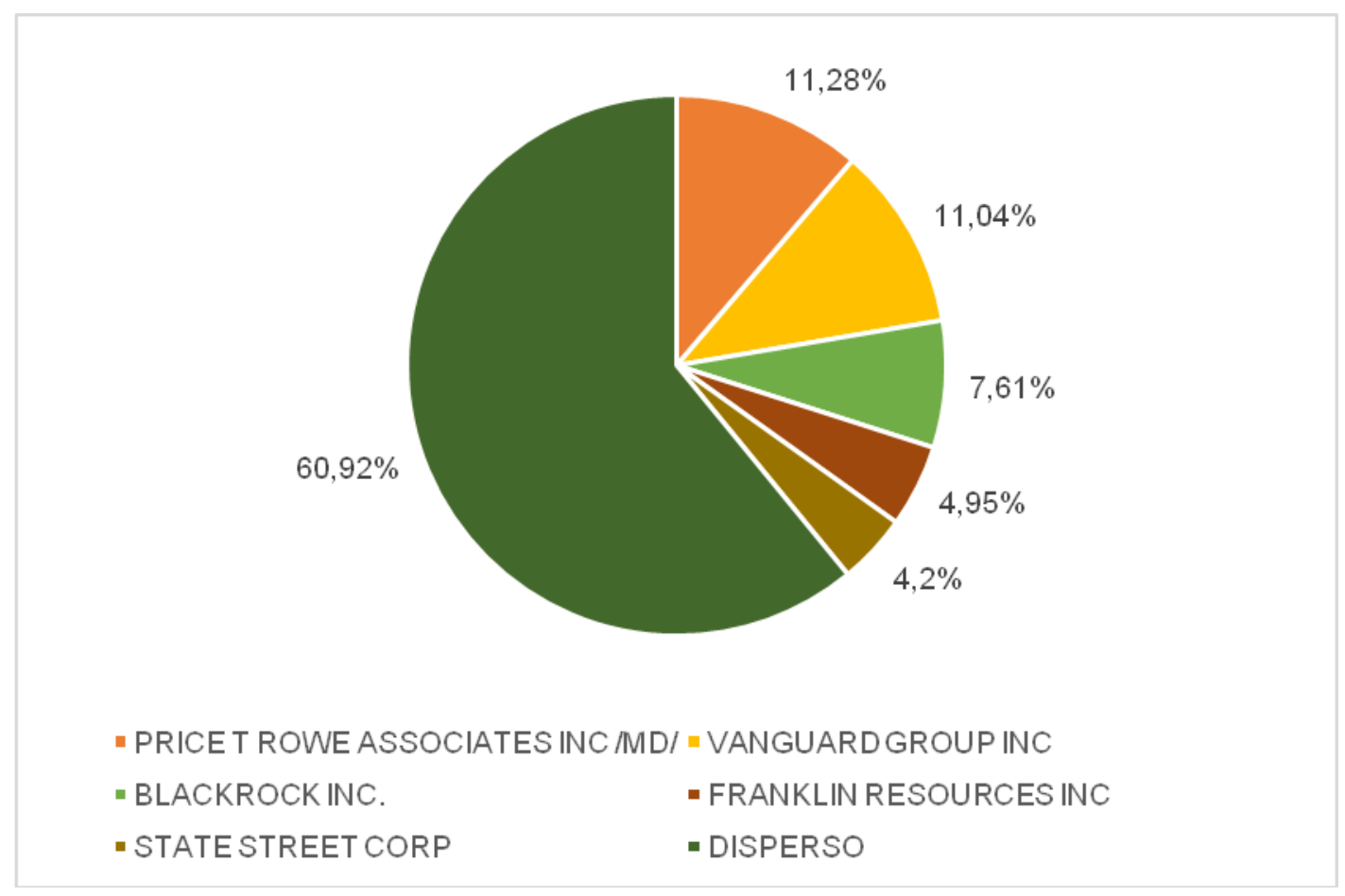

Fonte: https://www.nasdaq.com/symbol/bg/institutional-holdings em 01/07/2019

O fundo Price T. Rowe Associates é gerido pela empresa T. Rowe Price, sediada em Baltimore. Foi fundada em 1937, atua nos ramos de gerenciamento de fundos e fundos de pensão para pessoas físicas e investidores institucionais. Gerenciou em 2018 mais de U\$ 900 bilhões e atua em 47 países.

Faremos aqui uma pequena digressão acerca das dinâmicas de valorização em bolsa tanto da Bunge quanto da gestora de fundos para buscar deixar claro alguns aspectos importantes da racionalidade neoliberal da indústria de fundos e sua dinâmica enquanto alocação de recurso na economia mundial. 
A própria gerenciadora de fundos tem suas ações cotadas na Bolsa de Nova lorque e suas ações valorizaram, nos últimos 5 anos, cerca de 53\%, passando de 75 para 115 dólares a ação, em um movimento inverso ao da própria Bunge que, nesse mesmo período, caiu 36\%, conforme pode ser visto pelos gráficos abaixo.

Gráfico 5 - Variação diária da cotação das ações da Bunge (BG) na NYSE de out $/ 14$ a set/19

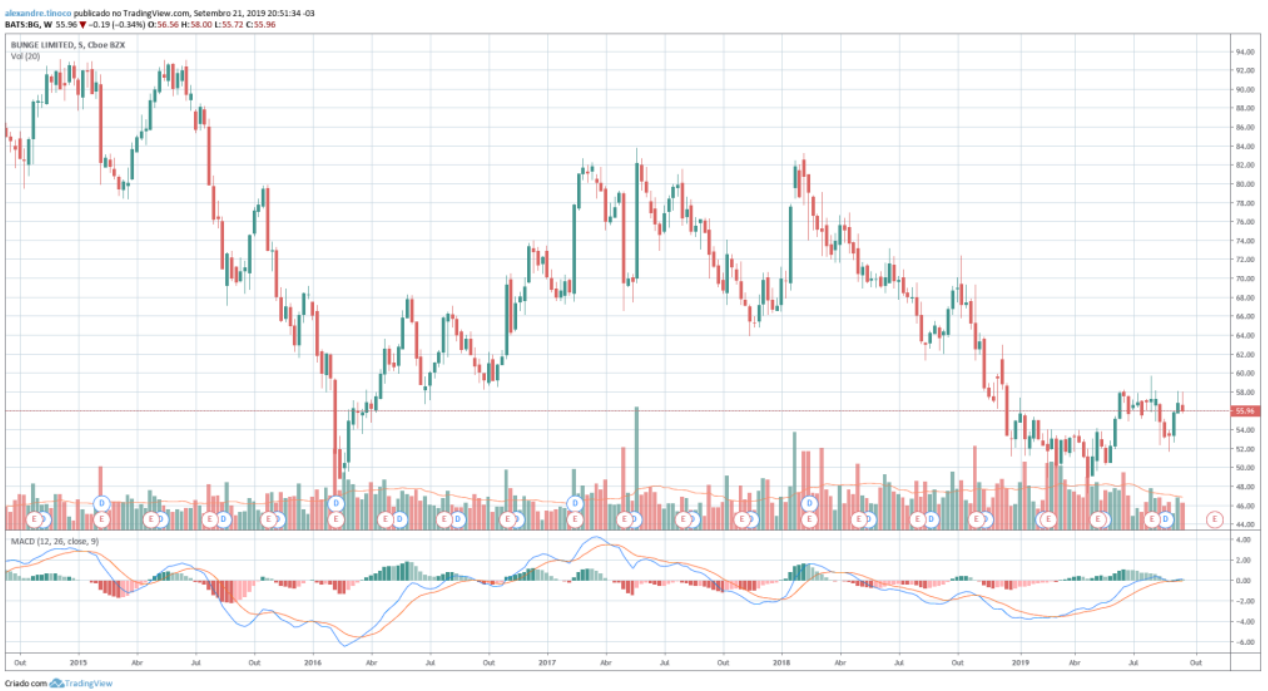

Fonte: https://br.tradingview.com/symbols/NYSE-BG/

Gráfico 6 - Variação diária da cotação das ações da Price T. Rowe (TROW) na NYSE de out/14 a set/19

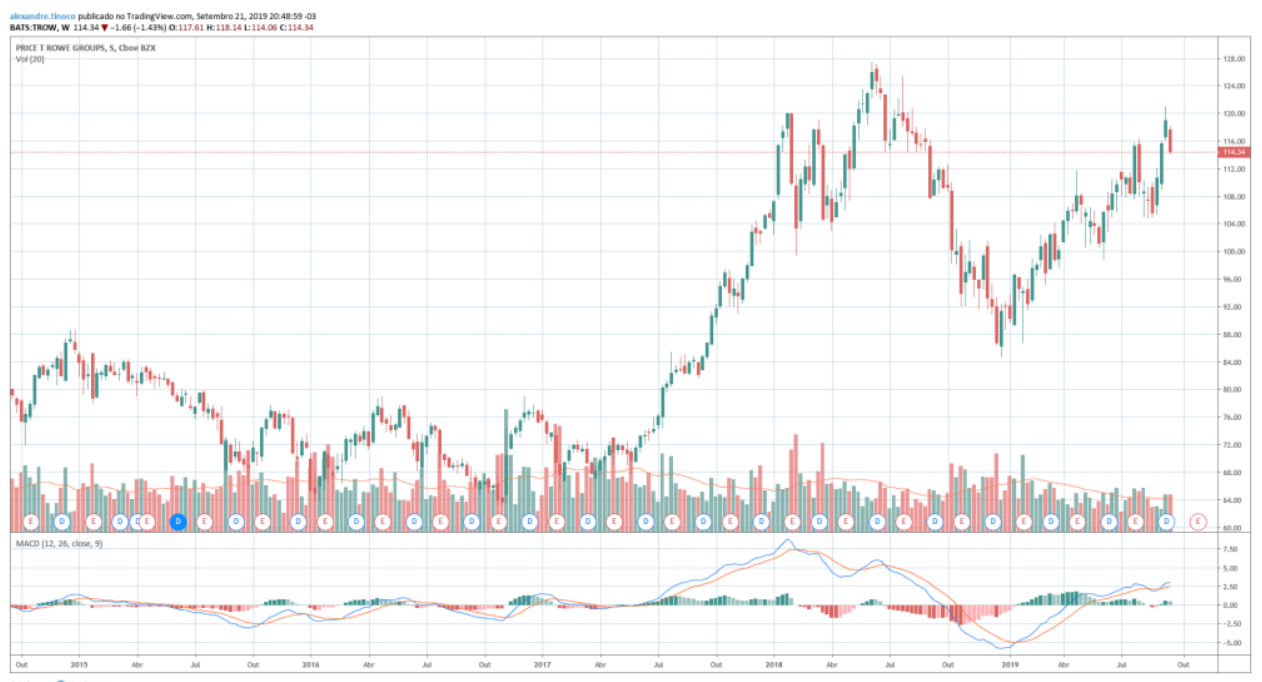

Fonte: https://br.tradingview.com/symbols/NASDAQ-TROW/

Do contraste desses dois gráficos pode-se perceber uma parte da estratégia de gerenciamento de riscos que é o investimento indireto em fundos 
de investimento, ao invés de diretamente em empresas da economia real, como é o caso da Bunge. Mesmo sendo o maior acionista institucional individual da Bunge, a gerenciadora de fundos Price T. Rowe ${ }^{122}$ foi capaz de apresentar valorização mesmo quando um ativo importante em seu portfólio apresentou perdas no mercado acionário, muito possivelmente por adotar estratégias diversificadas e uma gestão ativa de riscos.

A queda do valor das ações da Bunge, que investe e atua globalmente, atuando de forma diversificada, inclusive no investimento da ETC de Miritituba significa dizer que os acionistas da Bunge perderam dinheiro? Do ponto de vista do capital-fictício, sim. Os valores investidos no início de 2015 eram quase o dobro do valor de hoje. Mas o investidor que busca valorização de capital de longo prazo, para formação de aposentadoria, por exemplo, recebeu durante todo esse período o pagamento de dividendos. De acordo com o último dividendo pago, no dia 19/08/19, de 0,50 centavos de dólar por ação, podemos estimar que a Bunge paga, hoje, 3,63\% ao ano de dividendos em relação ao capital investido. Ou seja, uma remuneração de cerca de $80 \%$ acima da taxa de juros de referência no Estados Unidos, que hoje está em 2\% ao ano.

Portanto, deter a propriedade de ações da Bunge pode ser uma boa estratégia para quem deseja receber um fluxo constante de recursos, visando o longo prazo, acima da remuneração dos títulos do Tesouro norte-americano. No entanto, para diversificar o risco desse investimento, pode-se optar por investir em um fundo de pensão (que, ele também, ao investir na Bunge, irá receber os dividendos e distribuir para seus cotistas).

Desta forma, direta ou indiretamente, milhares de acionistas distribuídos pelo mundo todo são proprietários dos ativos da Bunge e deles usufruem todas as formas de produção e apropriação de mais-valia. Uma delas vem da renda da terra, como vimos no item 2.3.

A mesma lógica se aplica aos demais fundos que investem na Bunge. $O$ segundo maior acionista é The Vanguard Group ${ }^{123}$. Fundado em 1975, sediado na Pensilvânia, é o maior gerenciador de mutual funds do mundo, com uma 
carteira de $\bigcup \$ 5,3$ trilhões sob gerenciamento em setembro de 2018. O terceiro maior acionista é a gerenciadora Black Rock ${ }^{124}$, sediada em Nova lorque, fundada em 1988, é a maior gestora de ativos do mundo, tendo U\$4,72 trilhões sob seu gerenciamento, especialmente em ativos e gestão de risco. Atua globalmente, com 13.000 funcionários em 2016 e faturou em 2017 U\$ 12,5 bilhões.

O quarto maior acionista, com quase $5 \%$, é a gestora de fundos Franklin Templeton Investments ${ }^{125}$, fundada em 1947, em Nova lorque, mas que hoje é sediada em San Mateo, na Califórnia, a meio do caminho entre São Francisco e o Vale do Silício. Gerencia cerca de U\$ 740 bilhões, em mais de 200 fundos distintos.

Por último, o quinto maior acionista é um banco sediado em Boston, fundado em 1792 (segundo banco mais antigo dos EUA), o State Street Company ${ }^{126}$, que possui U\$ 31,6 trilhões sob sua custódia e administração.

Por último, importante notar que a Bunge possui filial no Brasil, com sede na Cidade de São Paulo, de onde gerencia suas operações e sua ETC em Miritituba.

\section{Figura 6 - Foto aérea da ETC da Bunge, Miritituba}

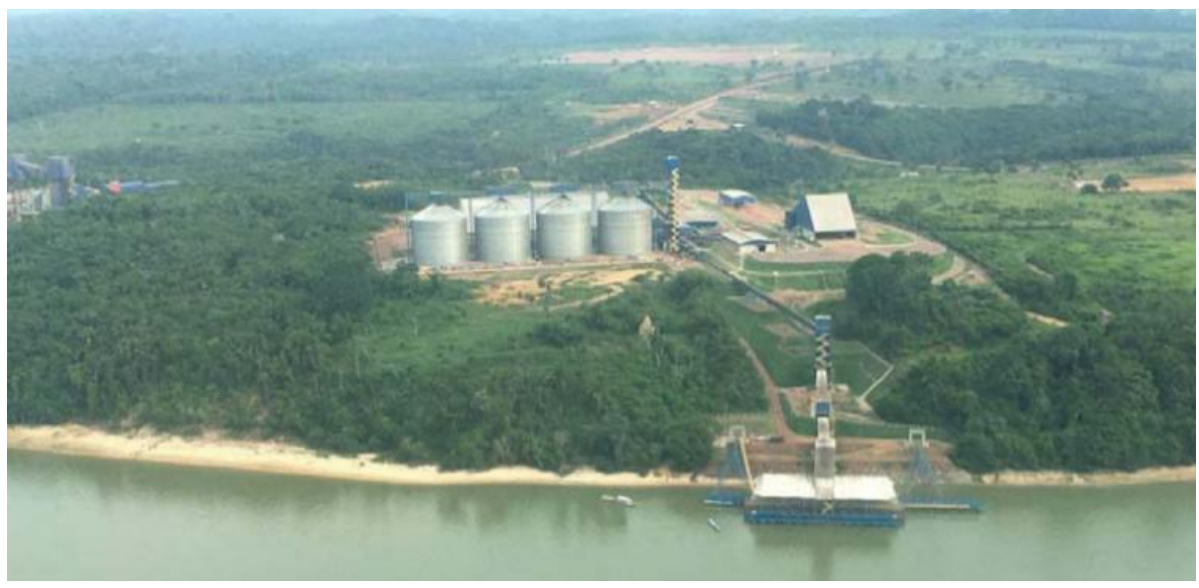

Fonte: Menezes (2017)

\section{Hidrovias do Brasil S.A.}

124 - https://pt.wikipedia.org/wiki/BlackRock

125 - https://en.wikipedia.org/wiki/Franklin_Templeton_Investments

126 - https://en.wikipedia.org/wiki/State_Street_Corporation 
A Hidrovias do Brasil S.A foi criada em 2010 especificamente para explorar projetos de logística na América Latina. Desde então vem atuando no transporte de minério de ferro, grãos e fertilizantes, tendo, nesse período, alavancado U\$ 697 milhões de aportes financeiros junto a seus investidores. Segundo dados da própria empresa ${ }^{127}$, cerca de $56 \%$ do capital está nas mãos do Grupo Pátria ${ }^{128}$ que se associou, em 2007, com o gigante de private equity The Blackstone Group, a maior firma do gênero em Nova lorque, que ainda detém, diretamente, mais $9,3 \%$, totalizando mais de $65 \%$ do capital sob sua influência.

\section{Gráfico 7 - Composição acionária da Hidrovias do Brasil S.A.}

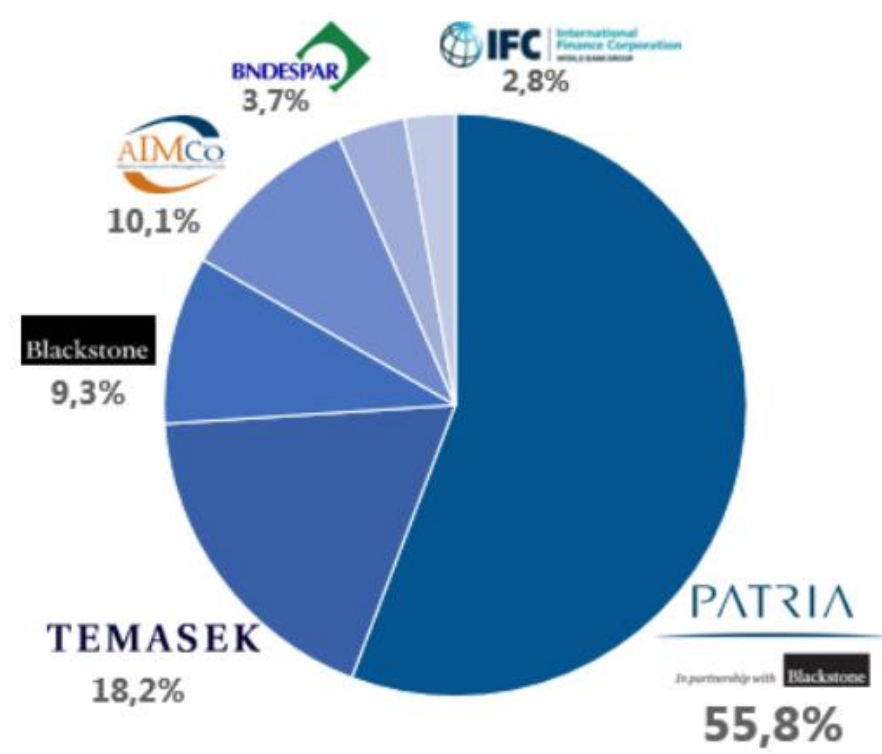

Fonte: http://hbsa.com.br/ - acessado em 01/07/19

127 - Segundo http://hbsa.com.br/, acessado em 01/07/19

128 - O Pátria que originou como Patrimônio, foi fundado no final da década de $1980 \mathrm{em}$ parceria com o banco Salomon Brothers. Com a entrada de investimento estrangeiro, o Patrimônio cresceu, e se tornou banco até ser vendido, em 1999, para o Chase Manhattan. Depois, os mesmos fundadores do Patrimônio fundaram o Pátria com a mesma proposta. 
O segundo maior shareholder, com $18,2 \%$, é o fundo Temasek, sediado em Cingapura, fundado em 1974 e que hoje gerencia mais de U\$ 308 bilhões em sua carteira ${ }^{129}$. Importante notar a participação de duas instituições financeiras de fomento, o BNDESPAR, com 3,7\%, e o IFC, com 2,8\%, sinalizando tanto o interesse do Governo Nacional em fomentar esse tipo de investimento quanto $o$ interesse de instituições multilaterais em estruturar a logística de cadeias globais de valor.

Figura 7 - Foto aérea da ETC da Hidrovias do Brasil, Miritituba

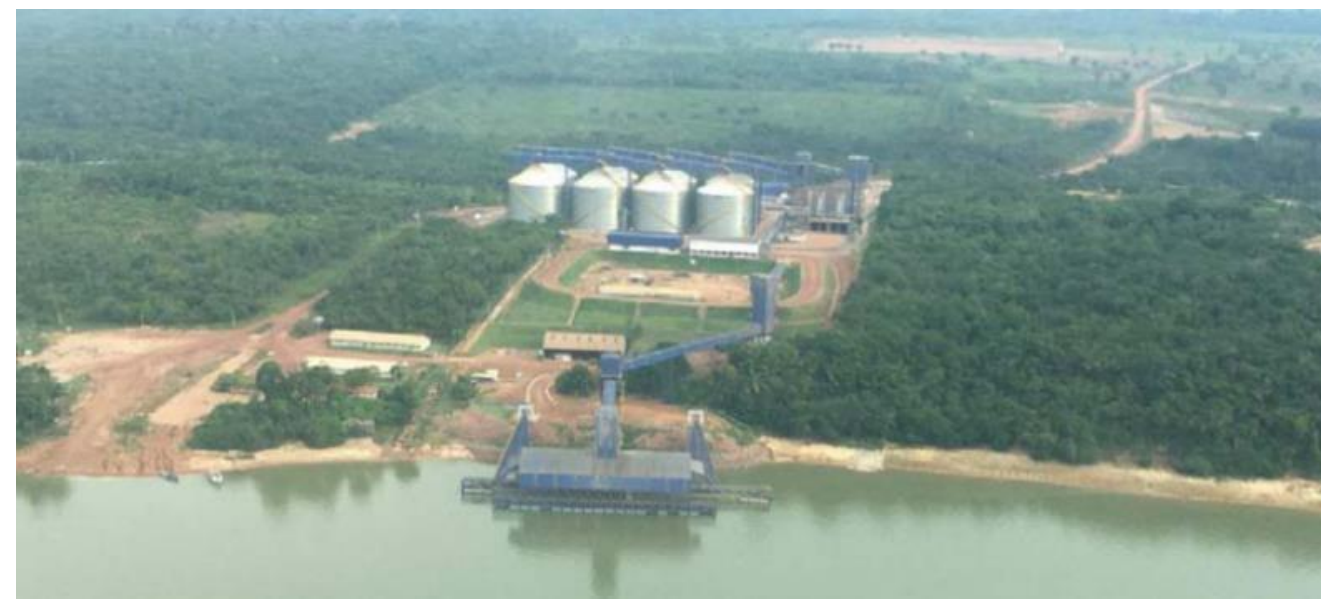

Fonte: Menezes (2017)

Além da ETC já construída em Miritituba, a Hidrovias do Brasil S.A. tem mais uma ETC em fase de estudos.

\section{CianPort}

A CianPort (Companhia Norte de Navegação e Portos) é formada pela Agrosoja de Sorriso, de propriedade de Cláudio Zancanaro, e pela Fiagril ${ }^{130}$, com sede em Lucas do Rio Verde (MT), do empresário Marino Franz. Com a venda de participações acionárias da Fiagril para, em 2014, o fundo de investimento Amerra Capital Management (25\%), sediado em Nova lorque, especializado em investimentos no agronegócio e em aquacultura, nas Américas e na Europa; e em 2016 para as chinesas Hunan Dakang e sua controladora Pengxin (57,57\%), sediada em Shangai, a composição acionária da Cianport ficou da seguinte forma:

129 - Segundo https://www.temasek.com.sg/en/who-we-are/about-us.html, acessado em 01/07/19 130 - https:/exame.abril.com.br/negocios/fundo-americano-amerra-compra-25-da-fiagril/ https://lavca.org/2016/04/29/chinas-hunan-dakang-invests-brazils-fiagril-em-portugues/ 
Gráfico 8 - Composição acionária da Cianport - 2019

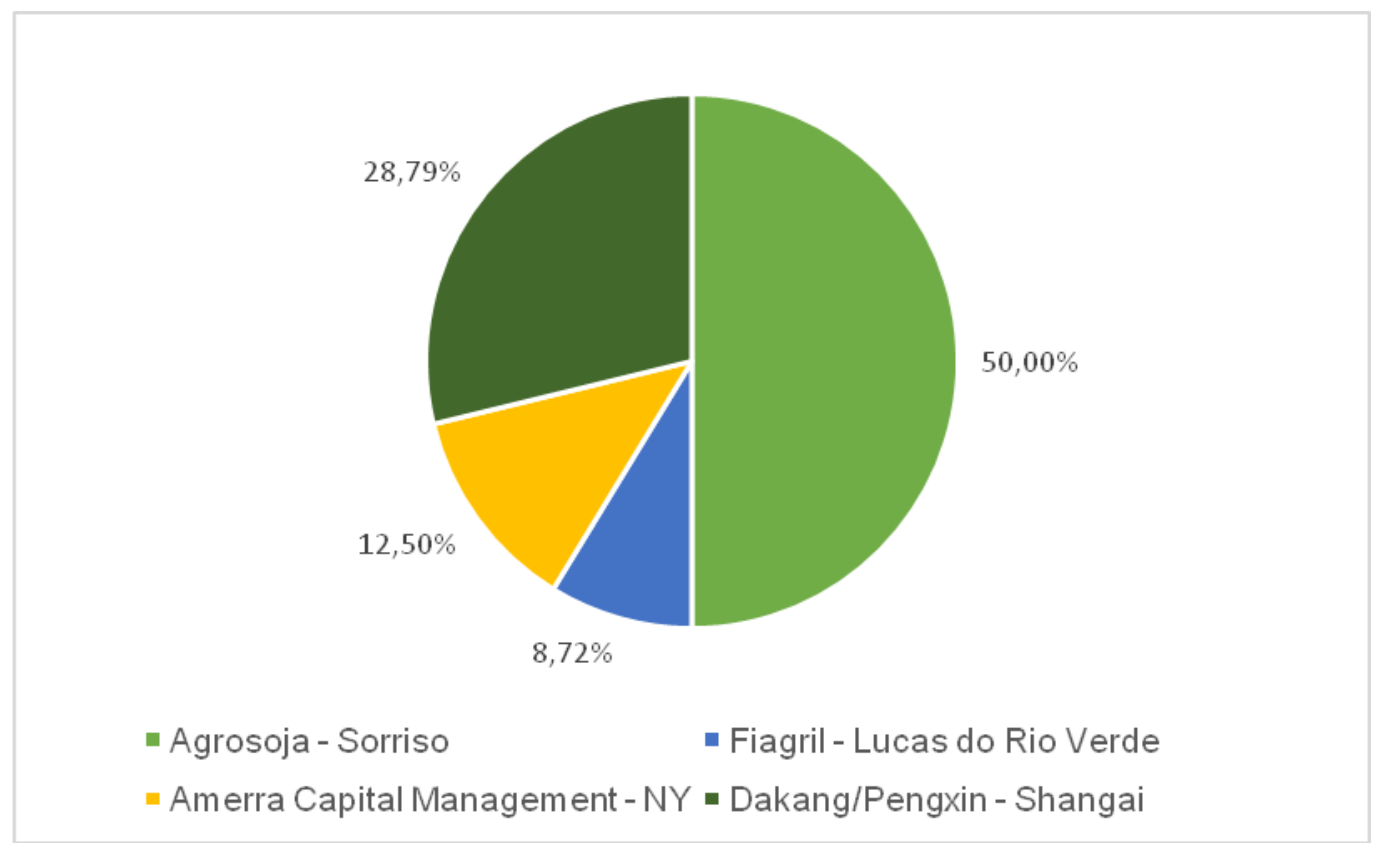

Fonte: elaboração própria

Desde 2013, a CianPort aposta em tradings regionais, em que movimentava cerca de 2 milhões de toneladas de soja e milho por meio das operações barter, que consiste na troca de insumos por produção agrícola. $O$ corredor logístico do Tapajós proporcionaria, de acordo com estimativas da empresa, cerca de 10 a $15 \%$ de economia nos custos dos fretes dos produtores do Estado de Mato Grosso. Além disso, em 2017, começa a operar em seu ciclo completo, da lavoura ao porto, do Centro-Oeste ao vetor de exportação Arco Norte, com o intuito de reduzir custos no transporte de soja e milho.

Figura 8 - Foto aérea da ETC da Cianport, Miritituba

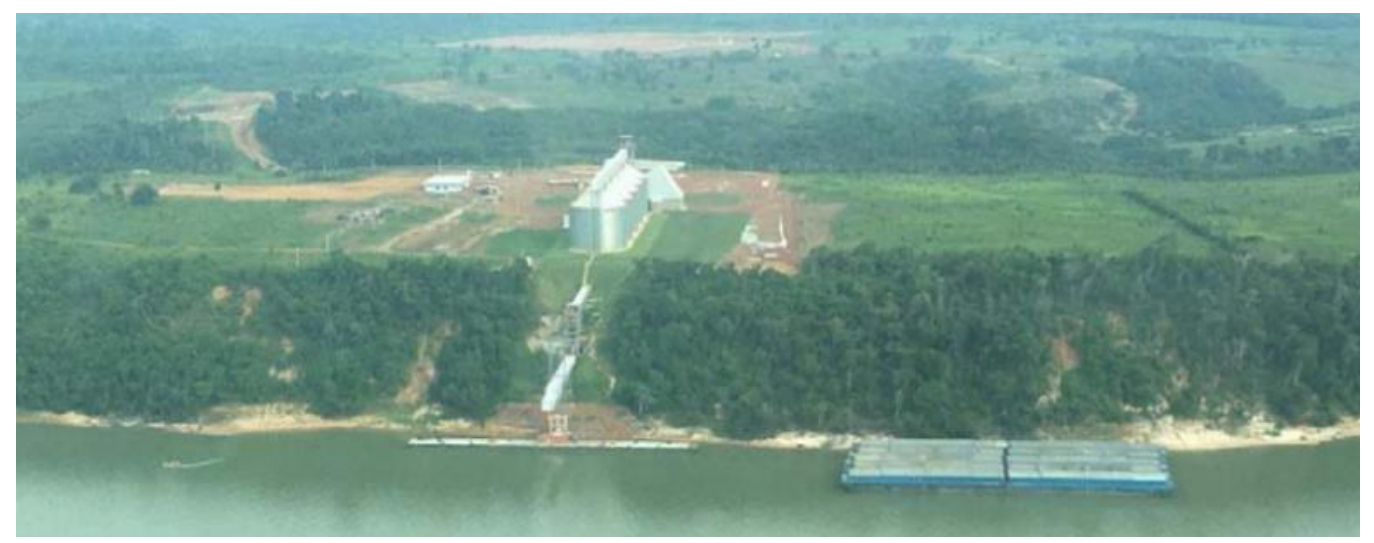

Fonte: Menezes (2017) 
Além da ETC já em funcionamento em Miritituba, a Cianport tem mais um projeto em fase de elaboração de EIA com instalação prevista para Rurópolis.

\section{Cargill}

É uma multinacional privada cuja matriz global se encontra nos EUA, Minnesota, na cidade de Mineápolis e sua atividade está centrada na produção e processamento de alimentos. Tornou-se a maior empresa de capital fechado do mundo. Distribuída em 70 países, sua sede no Brasil está localizada em São Paulo. Tem como subsidiárias a NatureWorks, Cargill Ltd., Cargill Meat Solutions, dentre outras. No Brasil, emprega cerca de 8 mil funcionários e está no ramo da comercialização de commodities agrícolas, produção de ingredientes para indústria alimentícia. Além disso, a empresa foi a primeira a instalar um porto graneleiro privado na cidade de Santarém, iniciando uma importante fase na região.

Figura 9 - Foto aérea da ETC da Cargill, Miritituba

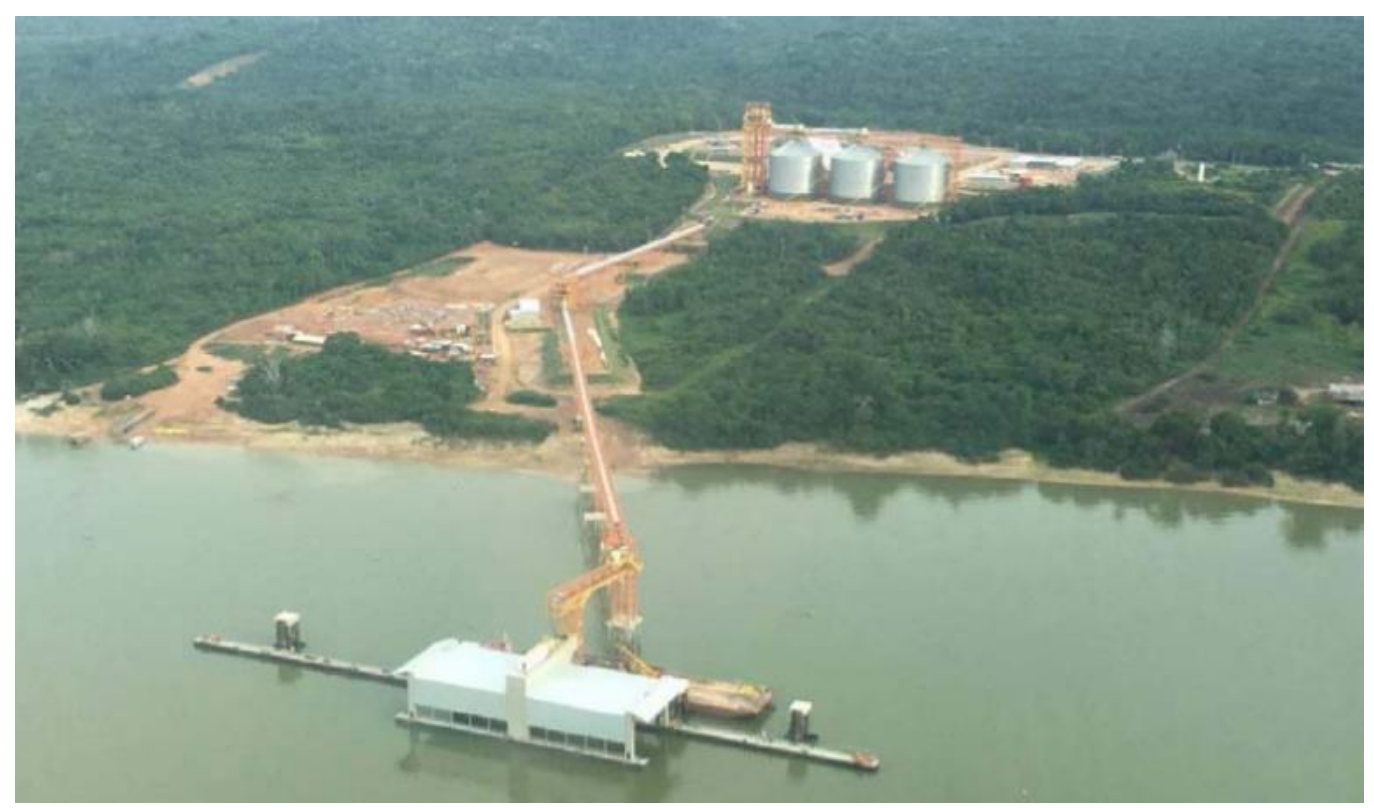

Fonte: Menezes (2017)

Além das ETCs já em operação, foi possível identificar mais 9 ETCs e 2 TUPs em fase de estudos ambientais em 2017, época da realização da pesquisa de campo. Abaixo, apresentamos, brevemente, o perfil de cada uma, sendo que 4 delas deverão se localizar a jusante no Rio Tapajós, também na margem direita, já em Rurópolis, conforme figura indicativa abaixo. 
Figura 10 - Foto aérea com indicativo de instalação de quatro novas ETCs, a jusante das já existentes.

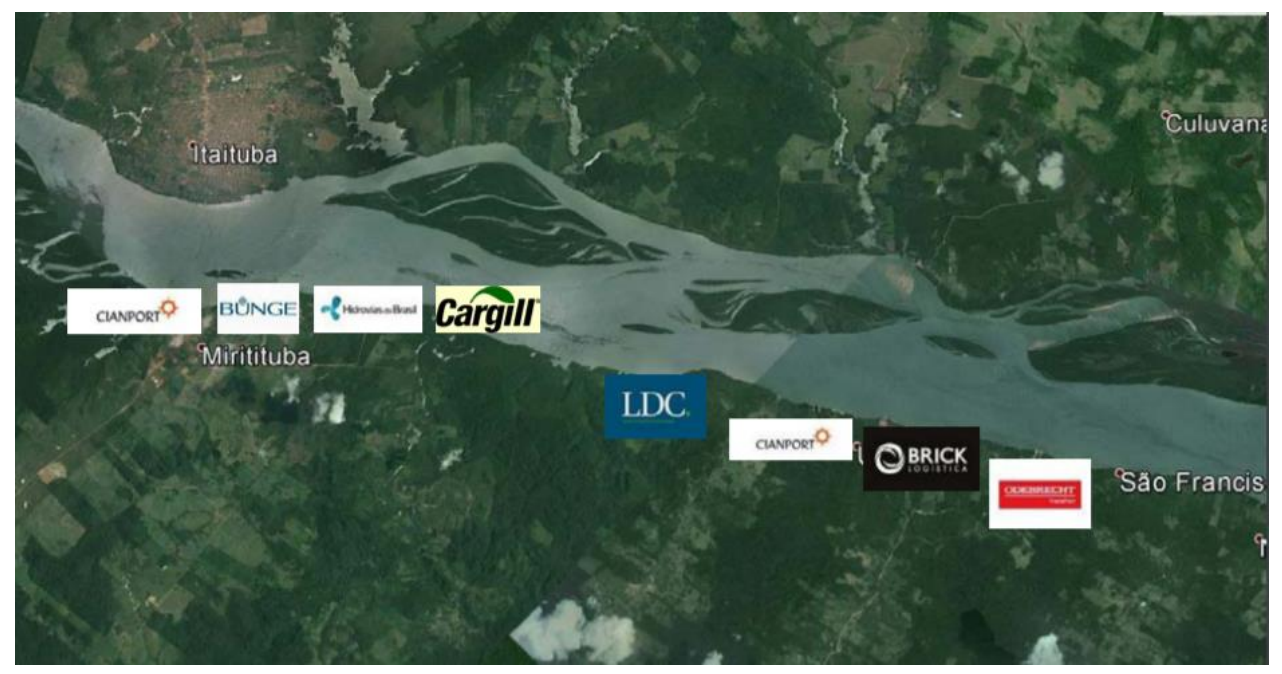

Fonte: Menezes (2017)

\section{EMBRAPS}

A Empresa Brasileira de Portos de Santarém é uma empresa de capital nacional, genuinamente santarena, que se originou do agronegócio e da pecuária do Mato Grosso em 2012. É administrada pelo empresário Pedro Riva. Demonstrando a imbricada relação entre setores públicos e privados, foi idealizada como um projeto de desenvolvimento econômico previsto pelo Plano Diretor Municipal. Com objetivo de reduzir custos (de 147 para 59 dólares por tonelada transportada, segundo estimativas da própria empresa), o projeto teve como investimento realizável mais de 650 milhões de reais na primeira fase e 250 milhões na segunda (segundo informado pela própria empresa). Um investimento na região que gerou a contratação de cerca de 800 empregos diretos no período de dois anos e meio de construção do projeto (FADESP, 2016). ${ }^{131}$

\section{Cevital}

Empresa privada multinacional fundada na década de 1970 na Argélia que investe em vários setores da economia, dentre eles o agronegócio e 
grande distribuição/logística, eletrônica e siderúrgica. No Brasil, a Cevital importa açúcar cru e exporta açúcar refinado para a Tunísia, Líbia e outras partes do Oriente Médio. Em 2016, a Cevital havia acordado com o Governo brasileiro a construção de uma siderúrgica em Marabá que não avançou em decorrência de impasses na negociação com a Vale quanto ao preço do minério de ferro. Tem sede na cidade de Argel.

\section{Ceagro $^{132}$}

Sua sede é em Campinas-SP, tendo sido fundada no final da década de 1980. Além disso, possui outras unidades operacionais nos Estados da Bahia, de Goiás, do Paraná, do Mato Grosso, do Mato Grosso do Sul, do Rio Grande do Sul e de São Paulo.

A Ceagro é uma empresa $100 \%$ brasileira que atua no comércio, importação, exportação e industrialização de produtos agrícolas e derivados no Brasil e no mundo. Ela está presente no mercado de soja, milho, sorgo, açúcar, defensivos, fertilizantes, armazenagem e logística. Os insumos representam quase $90 \%$ do custo da produção e são também fornecidos por meio do processo barter, como a CianPort.

\section{Louis Dreyfus Company ${ }^{133}$}

Com a sede brasileira na cidade de São Paulo, a Louis Dreyfus Company B.V. é uma das maiores empresas multinacionais de comércio no ramo agrícola - processamento de alimentos, transporte internacional e finanças. Na década de 1940, a empresa entrou no mercado brasileiro, tendo sido fundada em 1851, na França. Atualmente, a sede da holding do grupo fica em Amsterdã. No primeiro semestre de 2018, faturou US\$ 19 milhões empregando um total de 17 mil pessoas em mais de 53 países.

Está em fase de elaboração de EIA para a implantação de uma ETC no município de Rurópolis.

\section{$\underline{\text { Transportes Bertolini LTDA. - TBL }}{ }^{134}$}

132 - Disponível em: www.ceagro.com

133 - Disponível em: https://www.ldc.com/br/

134 - www.tbl.com.br 
Fundada há quarenta anos no Rio Grande do Sul, a empresa faz transporte de carga por diferentes modais (rodoviário e hidroviário), expandindo seu alcance para outras regiões do Brasil, com vinte filiais no Norte, Sul, Sudeste e Centro-Oeste. Está presente nas cidades de Manaus, Santarém, Belém, Macapá, Juruti, Paragominas e Porto Velho, principais portos de atendimento da frota hidroviária. As principais rotas estão nos rios Amazonas, Madeira, Tapajós e Capim. No Pará, operam sete unidades instaladas: Belém, Santarém, Itaituba, Juruti, Paragominas, Marabá e Altamira.

Está em fase de estudos ambientais para instalação de ETC em Rurópolis.

\section{Companhia Docas do Pará}

Fundada em 1967, a empresa administra os portos do Estado brasileiro do Pará. Em 1969 se tornou uma empresa de economia mista, tendo como acionista majoritário o Governo Federal. Além disso, exerce controle sobre as hidrovias da Amazônia Oriental. A Companhia é responsável por uma oferta de infraestrutura adequada a assegurar que o complexo portuário seja eficiente e seguro.

\section{Odebrecht Transport - OTP ${ }^{135}$}

A Odebrecht é um grupo global de origem brasileira fundado em 1944. Atualmente está presente em mais de 20 países nos setores de engenharia e construção, indústria, imobiliário, assim como no desenvolvimento e operação de projetos de infraestrutura e energia.

Em 2010 é formada a OTP que tem como subsidiárias a Odebrecht Rodovias S.A. e a Agrovia do Nordeste S.A. Ela tem como principais diretrizes implantar, operar e participar "de projetos nas áreas de mobilidade urbana, rodovias, portos e sistemas integrados de logística" (OTP, 2019). Sua participação acionária é composta por quase $60 \%$ da Odebrecht, 30\% de FGTS e $10 \%$ da BNDESPAR.

Deste breve levantamento sobre os agentes presentes nos novos investimentos que estão sendo realizados no baixo Tapajós visando a 
estruturação do Arco Norte, percebe-se uma gama bastante variada de players e estratégias. Encontramos tanto empresas de logística da região amazônica que buscam estar presentes nessa nova etapa, quanto empresas do próprio agronegócio, sobretudo do Mato Grosso, que buscam alternativas mais baratas para escoamento de sua produção. Junto com essas empresas, encontramos a estruturação da presença e expansão das atividades das tradings tradicionais, já há muito tempo presentes nessa região, bem como empresas estrangeiras que viram a oportunidade de entrar no mercado brasileiro com uma escala considerável (caso da argelina Cevital e da chinesa Pengxin).

Em quase todas essas formas de atuação, um elemento é presente: a atuação de fundos de investimentos, seja via participação acionária direta ou via detenção de lotes bastante significativos de ações negociadas na bolsa de valores de Nova lorque.

Desta forma, o Arco Norte, especificamente no baixo Tapajós, tem-se configurado em território de intensa disputa capital-capital visando a apropriação de mais-valia produzida no âmbito do agronegócio, configurando um espaço estruturado por uma centralidade do tipo metropolitano-neoliberal, entendida aqui enquanto a importância do lugar para o processo ampliado de acumulação de capital, seja para produção, seja para a distribuição de mais valia, ou ambos.

Para finalizar, vamos analisar, a partir dos mapas abaixo, como essa centralidade metropolitano-neoliberal se configura em termos de inserção na rede de cidades.

Em um primeiro recorte de análise, o que chamamos de conexão direta dos investimentos em Estações de Transbordo de Carga na região do baixo Tapajós, podemos identificar, pelo Mapa 4 abaixo, dois padrões bastante claros. 
Mapa 4 - Origem de capital do investimento no baixo Tapajós - conexões diretas, por percentual do investimento total (2017)

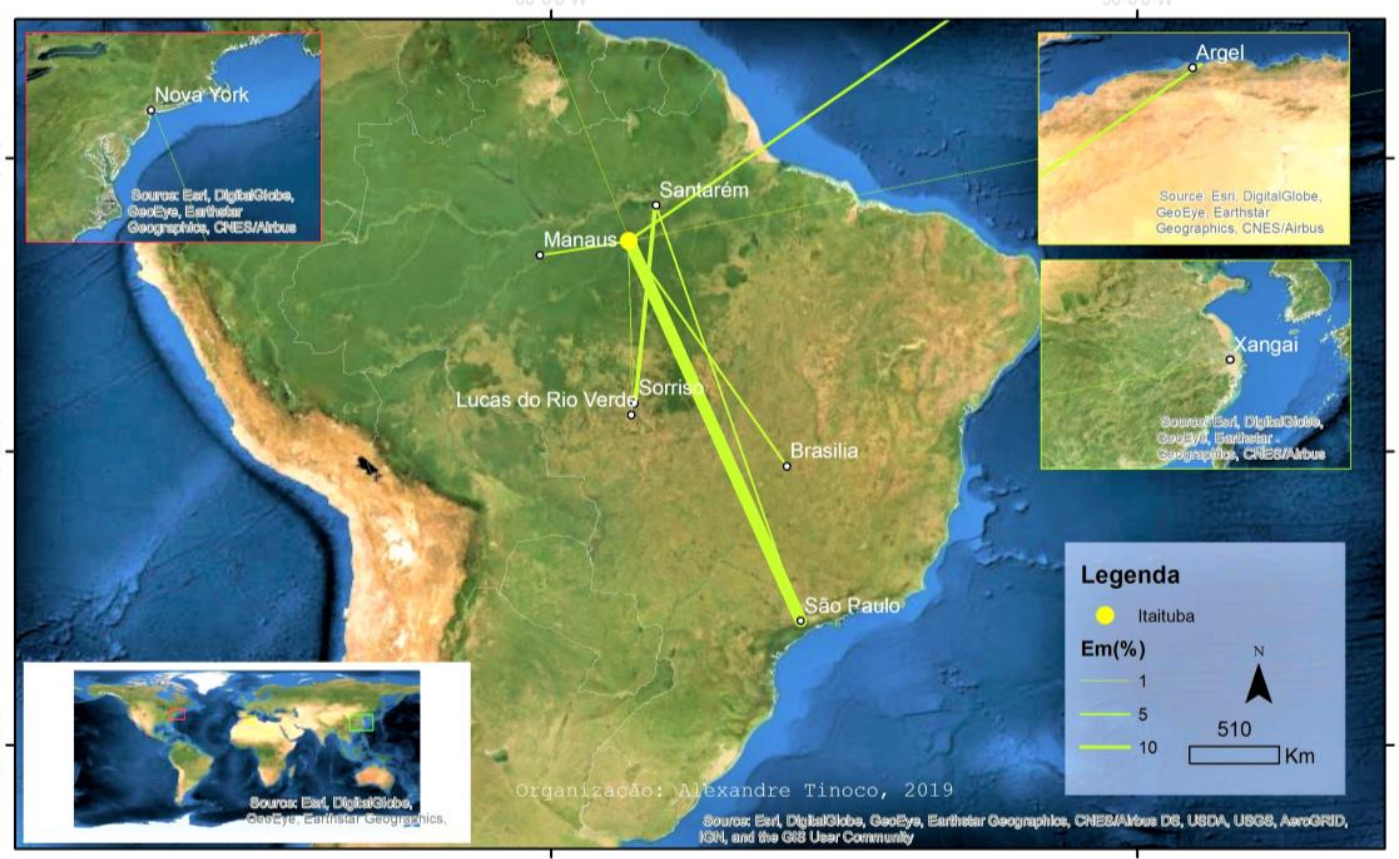

Primeiro, uma diferença muito grande entre a intensidade de investimento entre Santarém e a região de Itaituba. Lembrando que não evidenciamos a origem de capital de quase $12 \%$ do investimento total, Itaituba e Rurópolis foram e têm sido destino de 68\%, enquanto Santarém apenas de $20 \%$ do total de investimentos para a região. Essa "preferência" por Itaituba se deve, sobretudo, à maior disponibilidade de terra às margens do Tapajós e na proximidade da BR-163 - nas proximidades do Distrito de Miritituba (que faz fronteira entre Itaituba e Rurópolis, como vimos), com menos conflito de uso com áreas urbanas e menor poder de organização social das comunidades impactadas pelos projetos, em relação a Santarém, o que tem acelerado indevidamente os processos de licenciamento.

Um segundo padrão se evidencia pela leitura desse Mapa. Primeiro, que Santarém, diferentemente de Itaituba, não recebe investimento diretamente de nenhuma região externa ao Brasil, como pode ser visto também pelo Gráfico 9. Apresentando apenas três origens distintas - Sorriso-MT (13,58\% do total de investimentos), São Paulo $(5,18 \%)$ e, intermediada por São Paulo, de Mineápolis-EUA (1,17\%), Santarém parece demonstrar uma maior articulação com o poder econômico do próprio agronegócio. 
Gráfico 9 - Cidade de origem dos investimentos em Santarém - em participação percentual no total de investimentos no baixo Tapajós - 2017

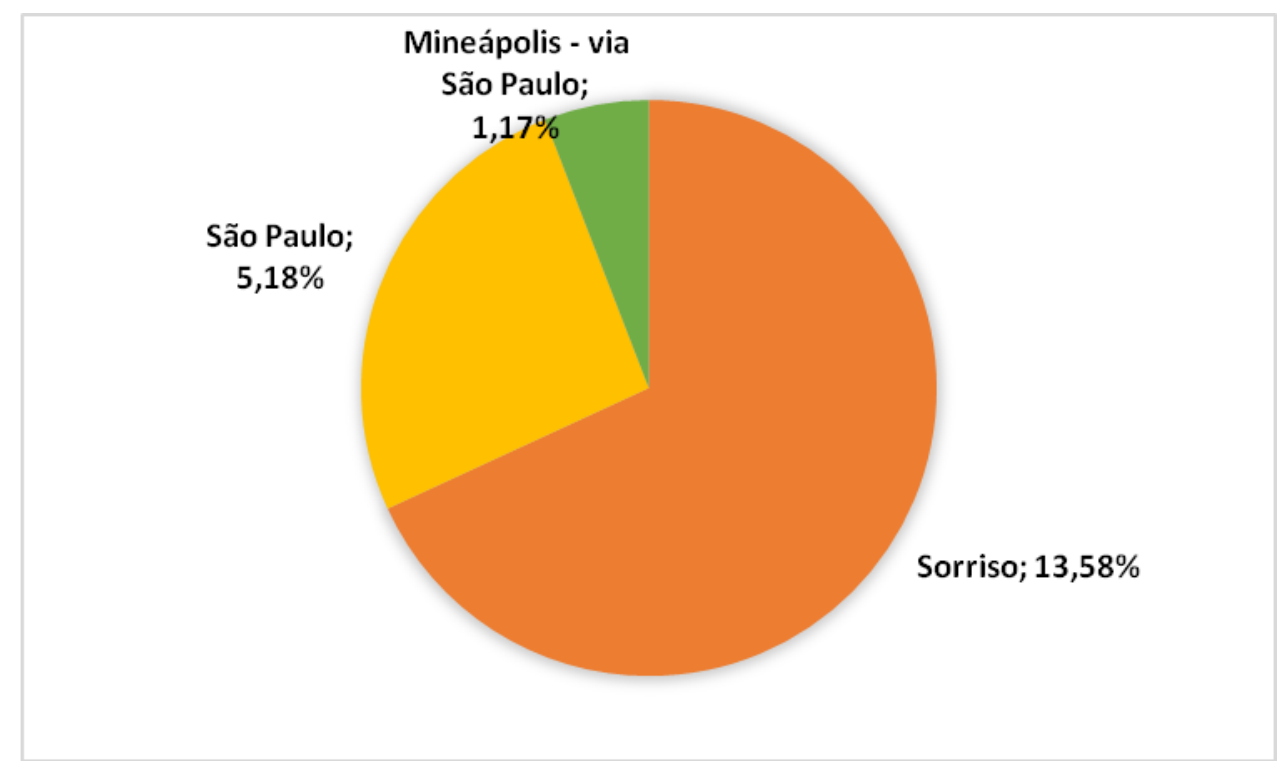

Fonte: elaboração própria

Itaituba, por sua vez, de acordo com o Gráfico 10, apresenta-se como alternativa a novos players e interesses mais difusos. Isso se evidencia quando vemos que Itaituba apresenta sete destinações diretas de investimentos, incluindo três internacionais, como as Cidades de Argel (10,36\% dos investimentos totais), na Argélia, Xangai (0,18\%), na China e Nova lorque $(0,26 \%$ dos investimentos totais) nos Estados Unidos. Isso quer dizer que capitais sediados nessas cidades, por meio de participações acionárias ou investimentos diretos (caso dos argelinos), investem diretamente em Itaituba, articulando-se junto aos parceiros e poderes locais. 
Gráfico 10 - Cidade de origem dos investimentos em Itaituba e Rurópolis - em participação percentual no total de investimentos no baixo Tapajós - 2017

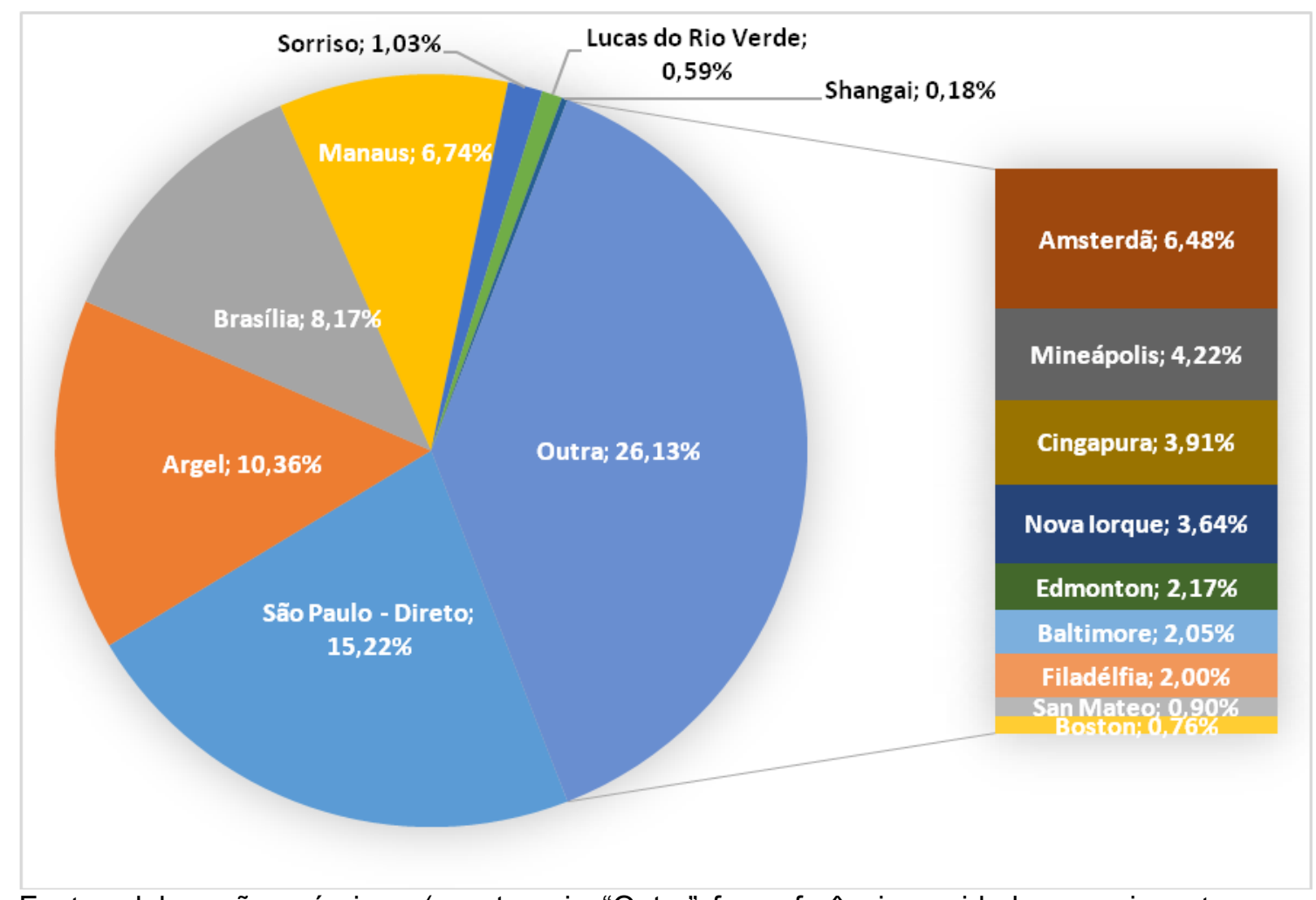

Fonte: elaboração própria - (a categoria "Outra" faz referência a cidades que investem em Itaituba por intermédio da sede de empresas localizadas em São Paulo)

No entanto, mais um segundo elemento se evidencia pelo Mapa 4. A enorme conexão de Itaituba com São Paulo, de onde, de forma direta, se originam $15,22 \%$ do investimento total na região, o que acaba também por indicar que a centralidade metropolitano-neoliberal, diferentemente da centralidade urbano-fordista que se dá por lógica de exclusão (o que polariza e o que é polarizado), se dá por lógica de complementariedade, na qual a intensificação da centralidade de Itaituba, por exemplo, se dá de forma concomitante ao reforço da centralidade da megarregião de referência no Brasil, no caso São Paulo.

Importante notar que esse processo não ocorre de forma excludente. Itaituba também se fortalece na relação com outras cidades brasileiras importantes, como é o caso de Brasília, sede dos fundos governamentais presentes na região e que contribuem com $8,17 \%$ do total dos investimentos; e Manaus, polo tradicional de empresas de logística na Amazônia, que representa 6,74\% desse investimento. O que também não impede Itaituba de se atrelar diretamente a interesses do agronegócio do Mato Grosso, com 
$1,03 \%$ dos investimentos provenientes de Sorriso e $0,59 \%$ provenientes de Lucas do Rio Verde.

No entanto, para compreendermos claramente a constituição conjugada dessa centralidade metropolitano-neoliberal de Itaituba, em conjunto com São Paulo, espacializamos, no Mapa 5 abaixo, a categoria "Outra" do Gráfico 10.

Isso nos permitiu analisar as conexões operadas a partir da intermediação da principal cidade brasileira, São Paulo, que mostra que mais do que a quarta parte $(26,13 \%)$ dos investimentos na região são provenientes do Exterior, de outras nove grandes cidades mundiais, que se articulam por meio de São Paulo para atuarem na região do baixo Tapajós.

Dentre elas, destacam-se Amsterdã, sede da LDC, com 6,48\% dos investimentos; Mineápolis, sede da Cargill, com 4,22\% e mais sete cidades, sedes de empresas gestoras de fundos de investimentos, que somam $15,43 \%$ do total de investimentos.

Ou seja, esta análise nos permite mostrar que, em termos de localidade de maior influência nos investimentos em andamento no Corredor Logístico do Tapajós, os fundos de investimento, que agregam investimentos de milhares de pessoas ao redor do mundo, são a "localização" de maior influência, com $15,43 \%$ do total, à frente da própria cidade de São Paulo, e das cidades de Sorriso e de Argel (dentre as que possuem fatia superior a 10\%).

Desta forma, podemos dizer que uma parte significativa dos investimentos no baixo Tapajós são a-espaciais, que se encontram nessa esfera dos fluxos financeiros globais. Em parte esta afirmação estaria correta, no entanto, esses fundos são gerenciados a partir dessas cidades, de suas sedes, que, uma vez atuando de forma global, conectando-se a nós importantes da rede global de produção de valor, como é o caso de São Paulo, conseguem se territorializar em projetos produtivos em vários lugares do mundo, dentre os quais o baixo Tapajós. Desta forma, a "localização" desses investimentos é a própria definição de rede de cidades mundiais que, por meio dos fluxos de capital, formam uma estrutura (em parte) única, de coordenação de alocação de capital fixo ao redor do globo. E é isso que imprime a Itaituba 
características de uma centralidade metropolitano-neoliberal, como a definimos.

Vale notar, a título de encerramento, que esse processo de territorialização de investimentos globais e locais em Itaituba, em grande medida intermediado por São Paulo, uma vez que entre recursos diretos ou indiretos, São Paulo comanda $41,35 \%$ dos investimentos de estruturação do Corredor Logístico do Tapajós, imprime e fortalece a própria centralidade metropolitano-neoliberal de megarregião de São Paulo, demarcando uma diferença nítida em relação a padrões de centralidade predominantes em outras épocas históricas, como, por exemplo, a centralidade urbano-fordista que marcou o auge do processo de industrialização da metrópole paulista. 
Mapa 5 - Origem de capital do investimento em Itaituba por tipo de conexão (2017)

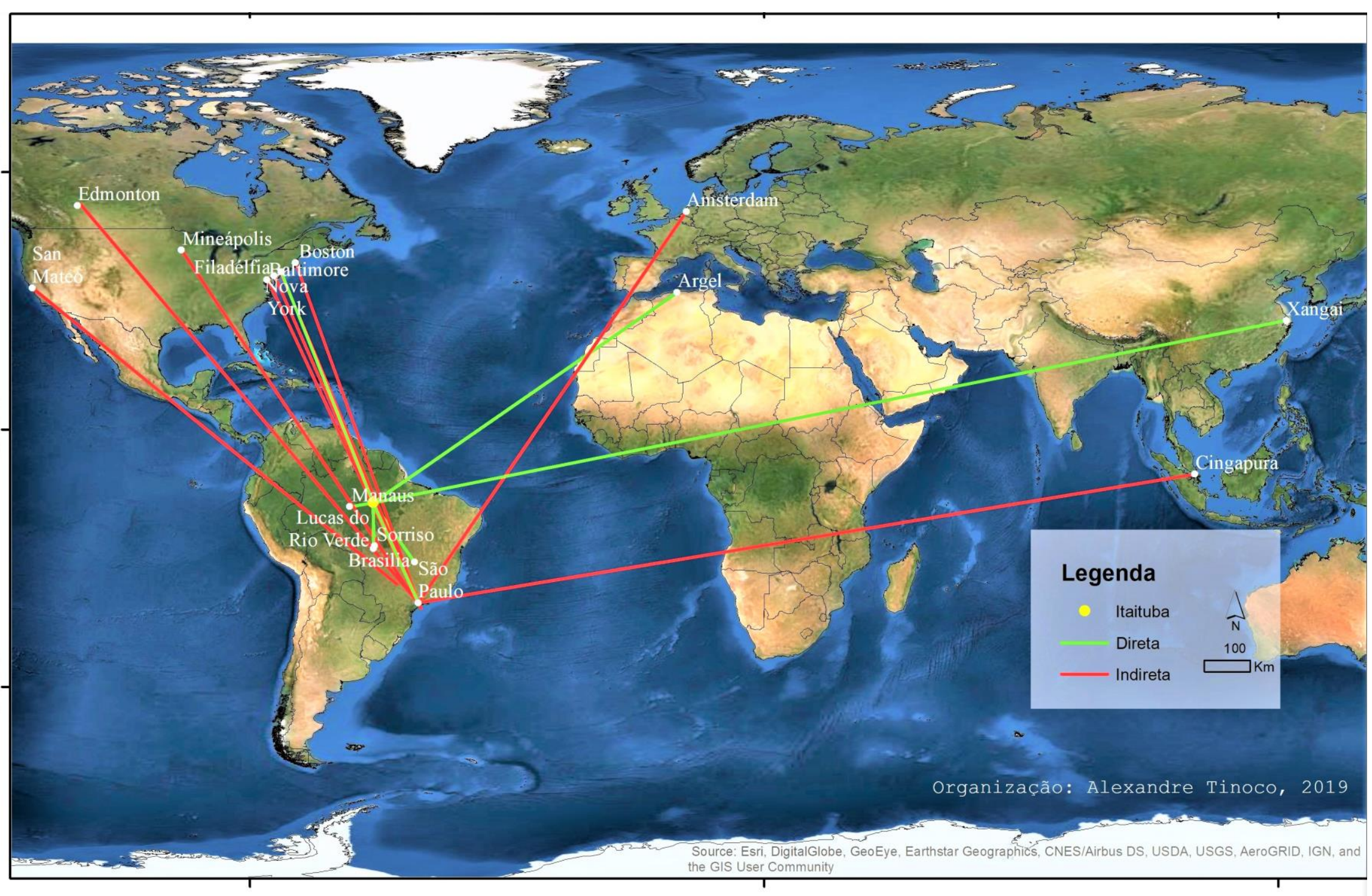




\section{Considerações finais}

Esta tese buscou promover o diálogo entre algumas correntes teóricas distintas, mas que se cruzam e se influenciam mutuamente, em um esforço de compreensão da contemporaneidade metropolitana como fenômeno urbano, tão marcante neste início do século XXI. Para tanto, ao retomar os passos que nos levaram a refletir, durante esses 20 últimos anos, acerca do estatuto desse metropolitano, ampliamos a abrangência e o alcance dos fenômenos estudados. Assim, a partir de um exemplo que consideramos icônico acerca dos processos produtores de espaço na sociedade que chamamos de metropolitano-neoliberal, pudemos captar elementos importantes da constituição da centralidade das megarregiões por meio da compreensão do modo como os elementos definidores dessa racionalidade metropolitanoneoliberal operam em um local em intenso processo de territorialização de capital fixo, o baixo Tapajós.

Do conjunto das reflexões e argumentações apresentadas nesta tese pudemos compreender (e defender) que a metrópole moderna não é uma resultante do processo de globalização. Ao contrário, ao promover a concentração e centralização de capital em níveis nunca antes alcançados, a metrópole moderna é uma das condições para o processo de globalização financeira dado que, nela, as possibilidades de reprodução ampliada do capital começam a se esgotar (entraves ao crescimento da produtividade, numa leitura neoclássica), justamente no momento em que os processos característicos do capitalismo financeiro neoliberal global se instauram. Nesta conjunção histórica específica, buscou-se fazer uma leitura que, reconhecendo as diferenças profundas entre as correntes de pensamento, almeja contextualizá-las em seus momentos históricos e, com isso, mostrar o que possuem de complementar para a compreensão desse movimento de múltiplas facetas do processo de desenvolvimento urbano contemporâneo.

Como resultado, argumenta-se que o movimento estudado indica que a metrópole moderna primeiro se conecta ao mercado financeiro global, quando se estabelecem as hierarquias das Cidades Globais e se reforçam os fluxos internacionais de capitais. Num segundo momento, tendo encontrado um 
arranjo territorial mais propício para sua reprodução ampliada, o capital relega para áreas até então não metropolitanas parte do capital fixo que, outrora concentrado na metrópole, deu-lhe sua forma e sua função enquanto cidade industrial. Nesse momento testemunhamos o esvaziamento industrial das grandes metrópoles, os processos de desindustrialização e crescimento de cidades médias num processo de desconcentração espacial da produção. É o chamado processo de dispersão metropolitana que, na realidade, dispersa 0 urbano da metrópole, deixando-a "livre" para exercer seu caráter de Cidade Global.

Com o novo fôlego que essas Cidades Globais adquirem, uma vez inseridas e atuantes nesses novos circuitos de acumulação ampliada do capital, fortalecem-se ainda mais e, na concorrência global entre cidades, constituem-se em Cidades-região, ainda a meio caminho entre uma metrópole de comando nacional ou regional e uma região de comando da economia mundial. É neste processo que a centralidade dessas grandes cidades e regiões se cinde, concentrando capital fixo em lugares com melhores oportunidades de comando da força de trabalho que passam e ser centralizados a partir das grandes cidades que, neste momento, e quanto mais centralizam capital, ao comandar capital concentrado, seja em seu entorno imediato, seja à distância, comandam a economia mundial e se constituem, então, em Megarregiões, expressão máxima da contemporaneidade metropolitana.

O caminho trilhado para chegar a essa compreensão se iniciou ainda em meu mestrado, quando, buscando compreender o que vinha ocorrendo com a metrópole paulista no final do século $\mathrm{XX}$, busquei propor a passagem de uma centralidade do tipo fordista para outra de tipo schumpeteriana, buscando acentuar a importância da cidade de São Paulo para o processo de difusão de informação para o processo de inovação.

$\mathrm{Na}$ sequência, estudei as externalidades dinâmicas de conhecimento e sua especificidade territorial, para compreender as lógicas de localização intraurbana das atividades inovadoras, com a preocupação de que seria necessário entender a racionalidade de localização dentro de uma cidade para que fosse possível entender a localização da atividade econômica nela. 
Simultaneamente às preocupações de cunho acadêmico, minha atuação profissional me levou a estudar o impacto de grandes empreendimentos nos territórios em que se instalam, em várias regiões do Brasil. De empreendimentos de mineração, de infraestrutura e do setor de óleo e gás, a implantação das Estações de Transbordo de Carga no baixo Tapajós nos chamou bastante a atenção pelo seu caráter articulador da cadeia global de produção do agronegócio, pelo potencial que têm de alterar fortemente a hierarquia das cidades da rede em que estão inseridos, devido à magnitude do investimento frente a economias municipais de pequeno porte.

A partir do aprofundamento da compreensão desses investimentos no Corredor Logístico do Tapajós, decorrente de uma pesquisa de campo junto à Secretaria de Meio Ambiente e Sustentabilidade do Pará, e do levantamento de dados secundários acerca da estrutura acionária desses projetos, pudemos identificar que o maior "investidor individual" nessas ETCs vem da chamada "indústria de fundos de investimento", o que adiciona à nossa compreensão o caráter financeirizado (para além do globalizado) dos investimentos em questão.

Ao mesmo tempo, decorre desses levantamentos a visão de que esses investimentos são também expressão dos fluxos financeiros globais que contribuem para a estruturação da rede de cidades globais, devido à grande quantidade de cidades sede dos fundos de investimento que, por meio de participações acionárias, atuam no baixo Tapajós, mesmo que à distância. Estados Unidos, Europa, Ásia se articulam nesses investimentos que contribuem para a expansão da cadeia produtiva global de grãos, especialmente soja e milho e, para isso, concentram capital fixo na região de Itaituba.

Como nó mais importante dessa articulação entre global e local, mostramos que a megarregião de São Paulo comanda, direta ou indiretamente, mais de $40 \%$ do investimento nas ETCs do baixo Tapajós, o que nos permite argumentar que sua centralidade, em conjunto com a alteração da centralidade de Itaituba, se consolida nessa lógica metropolitano-neoliberal de forma articulada, em um movimento de incorporação de Itaituba, por meio de São Paulo, à rede de cidades mundiais, naquilo que entendemos como também 
sendo uma expressão do processo de metropolização, processo para cuja compreensão, ao fim e ao cabo, esperamos ter contribuído nesta tese. 


\section{Referências}

ABRAMO, Pedro. A Regulação Urbana e o Regime Urbano: a Estrutura Urbana, sua Reprodutibilidade e o Capital. Ensaios FEE - ISSN:0101-1723 p. $43,1995$.

ABU-LUGHOD, Janet Lippman. Comparing Chicago, New York and Los Angeles: testing some world cities hypothesis. In: KNOX, Paul L.; TAYLOR, Peter J. (Orgs.). . World Cities in a World System. New York: Cambridge University Press, 1995. p. 171-191.

AGLIETTA, Michel. Régulation et crises du capitalisme. Paris: [s.n.], 1976. .

AGUIAR, Diana. A geopolítica de infraestrutura da China na América do Sul: um estudo a partir do caso do Tapajós na Amazônia Brasileira. Rio de Janeiro: ActionAid Brasil, 2017. 88 p. .9788589473194.

AMIN, Ash. Post-Fordism: Models, Fantasies and Phantoms of Transition. In: ASH, Amin (Org.). . Post-Fordism: a reader. Oxford: Blackwell Publishers Ltd, 1994. p. 1-40.

AMORIM, Teresinha. Tapajós: história, riqueza e exploração do mais belo rio do mundo. Revista do Instituto Histórico e Geográfico do Tapajós , 2013.

ARIENTI, Wagner Leal. Uma análise regulacionista das reformas do estado capitalista: rumo ao estado pós-fordista? Textos de Economia v. 8, n. 1, p. 1$36,2002$.

ARRIGHI, Giovanni. A ilusão do desenvolvimento. São Paulo: Vozes, 1997. . ARROYO, Mónica. Fluidez e porosidade do território brasileiro no contexto da integração continental. In: SILVEIRA, María Laura (Org.). . Continente em chamas: globalização e território na América Latina. São Paulo: Civilização Brasileira, 2005. p. 211-242.

ARROYO. Mónica. Flujos mercantiles y división territorial del trabajo en Brasil Goods flows and territorial division of labor in Brazil today. Revista Geográfica Venezolana [S.I: s.n.], 2014.

ARROYO, Mónica. Território nacional e mercado externo: uma leitura do Brasil na virada do século XX. Universidade de São Paulo, 2001. 250 p.

ASCHER, François. La République contre la ville. Essai sur l'avenir de la France urbaine. , 1998.

ASCHER, François. Los Nuevos principios del urbanismo: el fin de las ciudades no está a la orden del día. Madrid: Alianza Editorial, 2004. .8420641987 .

ASCHER, François. Métapolis : ou L’avenir des villes. [S.I.]: Éditions Odile Jacob, 1995. Les grandes villes sont le lieu par excellence où les hommes créent, échangent, se rencontrent. Comment mieux maîtriser le développement urbain? Quel urbanisme mettre en oeuvre?2738103170.

ASCHER, François. Une nouvelle révolution urbaine ? In: LACOUR, Claude; PUISSANT, Sylvette. (Orgs.). . La métropolisation : croissance, diversité, 
fractures. Paris: Anthropos, 1999.

BAIRD, Alfred J. Acquisition of UK ports by private equity funds. Research in Transportation Business and Management v. 8, p. 158-165, out. 2013.

BARON-TOE, Catherine. Autonomie et intégration des espaces urbains africains. Université de Bordeaux-IV, 1995.

BAUMONT C., P.-P. COMBES et al. Économie Géographique: Les théories à l'épreuve des faits. Paris: ECONOMICA, 2000. .

BAUMONT, C; HURIOT, J M. L'interation agglomération-croissance en économie géographique. In: BAILLY, A; HURIOT, J M (Orgs.). . Villes et Croissance: Thèories, modèles, perspectives. Paris: Anthropos, 1999.

BECATTINI, G. O distrito marshalliano. As Regiões Ganhadoras: distritos e redes, os novos paradigmas da geografia econômica. Lisboa: Celta, 1994. p. 19-32.

BENABOU, Roland. Equity and Efficiency in Human Capital Investment: The Local Connection. The Review of Economic Studies v. 63, n. 2, p. 237 , abr. 1996.

BINET, Marie-Estelle. Mobilité territoriale et comportements dépensiers des collectivités territoriales. Université de Rennes-1, 1997.

BOUDEVILLE, Jacques-R. Les spaces économiques. Paris: Press Universitaires de France, 1961. 127 p. .

BOURDEAU-LEPAGE, Lise; HURIOT, Jean-Marie. Metropolises and Global Coordination. A Historical perspective. 2003, Paris: AFSE congress 2003, 2003.

BOYER, Robert. Théorie de la régulation. Une analyse critique. Paris: La Découverte, 1986. .

BRANCO. Maria Luiza Castelo. Espaços urbanos: uma proposta para o Brasil. [S.I: s.n.], 2003.

BRENNER, Neil. Debating planetary urbanization: For an engaged pluralism. , 2013.

BROUSSEAU, E; RALLET, Alain. Technologies de l'information, organisation et performances économiques. Paris: Commissariat général du Plan, 1999. .

BROWDER, John O; GODFREY, Brian J. Cidades da floresta: urbanização, desenvolvimento e globalização na Amazônia brasileira. Manaus: Ed. UFAM, 2006. .

CÂMARA DOS DEPUTADOS. Centro de Estudos e Debates Estratégicos.

Arco Norte: um desafio Logístico. Brasília: Edições Câmara, 2016.9788540205666.

CASTELLS, Manuel. A sociedade em rede. São Paulo: Paz e Terra, 1999. .

CASTILLO, Ricardo; FREDERICO, Samuel. Dinâmica regional e globalização: espaços competitivos agrícolas no território brasileiro. Mercator v. 09, n. 18, p. 17-26, 2010.

CASTRO. Edna. Expansão da fronteira, megaprojetos de infraestrutura e 
integração sul-americana. [S.I: s.n.], 2012.

CATIN, Maurice. Externalités. Encyclopédie d'Économie Spatiale. Paris:

Econômica, 1994.

CHARLOT, Sylvie. Economie géographique et croissance régionale : le rôle des infrastructures publiques. Université de Bourgogne, 1999.

CHESNAIS, François. A mundialização financeira: gênese, custos e riscos. 1. ed. São Paulo: Xamã, 1998. 334 p. .

CHRISTALLER, Walter; BASKIN, Carlisle W. Central Places in Southern Germany. New Jersey: Prentice-Hall, 1966. .

CICCOLELLA, Pablo; MIGNAQUI, lliana. Metrópolis latinoamericanas:

fragilidad del Estado, proyecto hegemónico y demandas ciudadanas . [S.I: s.n.]. , 2008

CLARK, C. Urban population densities. Journal of Royal Statistical Society 114 p. 490-494, 1951.

CLEMENTE, Ademir; HIGACHI, Hermes Y. Economia e desenvolvimento regional. São Paulo: Atlas, 2000. .

COMBES, P P. Intégration économique - Localisation et régulation des entreprises. EHESS, 1996.

CORADE, Nathalie. Métropolisation et dynamique métropolitaine. , 1993.

CORBOZ, André. Hyperville. Cahier 8 p. 112-128, 1994.

CORNU, J-Y. Les cofinancements entre collectivités publiques. Université Paris X-Nanterre, 1999.

CORRÊA, Roberto Lobato. A organização urbana. Geografia do Brasil:

Região Norte. Rio de Janeiro: [s.n.], 1990. 3 v. p. 255-271.

CORRÊA, Roberto Lobato. A periodização da rede urbana amazônica. Revista Brasileira de Geografia v. 3, n. 49, p. 39-67, 1987a.

CORRÊA, Roberto Lobato. A periodização da rede urbana amazonica Correa recorte. Revista Brasileira de Geografia v. 49, n. 3, p. 39-68 , 1987b.

CORRÊA, Roberto Lobato. A rede urbana. São Paulo: Ática, 1989. .

CORRÊA, Roberto Lobato. Estudos sobre a rede urbana. Rio de Janeiro:

Bertrand do Brasil, 2006. .

CORRÊA, Roberto Lobato. Redes Geográficas: Reflexões Sobre Um Tema

Persistente. Revista Cidades v. 9, n. 16 , 2012.

CORREA, Vivian Helena Capacle; RAMOS, Pedro. A precariedade do transporte rodoviário brasileiro para o escoamento da produção de soja do Centro-Oeste: situação e perspectivas. RESR v. 48, n. 02, p. 447-472 , 2010.

DARDOT, Christian; LAVAL, Pierre. A Nova Razão do Mundo. Paris: Boitempo, 2010a. .

DARDOT, Christian; LAVAL, Pierre. La nouvelle raison du monde: essai sur la société néolibérale. La Découve ed. Paris: [s.n.], 2010b. 504 p. .

DERYCKE, Pierre-Henri. Comprendre les dynamiques métropolitaines. La 
metrópolisation. Croissance, Diversité, Fractures. Paris: Anthropos, 1999. p. 1-19.

DERYCKE, Pierre-Henri. Regards sur l'économie urbaine 40 ans de recherches francophones (1965-2007). Revue d'Économie Régionale \& Urbaine v. avril, n. 2, p. $239,2009$.

DIAS, Catharina Vergolino. Vida urbana na Amazônia. Revista Econômica BASA v. 1, n. 2, p. 13-20, 1972.

DINIZ, Clélio Campolina; CROCCO, Marco. Introdução - Bases teóricas e instrumentais da economia regional e urbana e sua aplicabilidade ao Brasil: uma breve reflexão. In: DINIZ, Clélio Campolina; CROCCO, Marco (Orgs.). . Economia Regional e Urbana: Contribuições Teóricas Recentes. 1. ed. Belo Horizonte: Editora UFMG, 2005. p. 9-31.

DIXIT, Avinash K; STIGLITZ, Joseph E. Monopolistic Competition and Optimum Product Diversity. American Economic Association, N. 3 v. 67, p. 297-308, jun. 1977.

DURANTON, Gilles. La nouvelle économie géographique: agglomération et dispersion. 131 p. 1-24 , 1997.

DURANTON, Gilles; PUGA, Diego. Diversity and Specialisation in Cities: Why, where and when does it matter? Urban Studies v. 37, n. 3, p. 533-555, 2000.

ELLISON, G; GLAESER, E. Geographic Concentration in U.S. Manufacturing Industries: A Dartboard Approach. Journal of Political Economy v. 105, p. 889-927, 1997.

ENGLMANN, F C; WALZ, U. Industrial centers and regional growth in the presence of local inputs. Journal of Regional Science v. 35, p. 3-27, 1995.

FADESP. RELATÓRIO DE IMPACTO AMBIENTAL TERMINAL DA EMBRAPS. [S.I: s.n.], 2016.1514399628.

FAVARDIN, Pierre. La compétition entre collectivités locales. Revue économique v. 47, n. 2, p. 365-381, 1996.

FERREIRA, José Freire da Silva. Rede urbana amazônica: subsídios para uma política de desenvolvimento regional e urbano. Cadernos NAEA v. 3 , 1977.

FIORAVANTI, Lívia Maschio. Do agronegócio à cidade como negócio: a urbanização de uma cidade mato-grossense sob a perspectiva da produção do espaço. Universidade de São Paulo, São Paulo, 2019. Disponível em: <http://www.teses.usp.br/teses/disponiveis/8/8136/tde20052019-130648/>. Acesso em: 5 set. 2019.

FLORIDA, Richard. Foreword. In: ROSS, Catherine Laverne (Org.). . Megarregions: planning for global competitiveness. [S.I.]: Island Press, 2009. p. 307.

FLORIDA, Richard. The Rise of the creative class: And How It's Transforming Work, Leisure, Community and Everyday Life. [S.I.]: Basic Books, 2002. .

FLORIDA, Richard; GULDEN, Tim; MELLANDER, Charlotta. The rise of the mega-region. Cambridge Journal of Regions, Economy and Society v. 1, n. 3, p. 459-476, nov. 2008. 
FORAY, D. L'economie de la connaissance. Paris: La découverte, 2000. .

FREEMAN, C; PEREZ, C. Structural crises of adjustment: business cycles and investment behavior. In: DOSI, G. et al. (Orgs.). . Technical Change and Economic Theory. London: Pinter Publishers, 1988. p. 38-66.

FREEMAN, Christopher; CLARK, John; SOETE, Luc. Unemployment and Technical Innovation; A Study of Long Waves and Economic Development. Westport, Connecticut: Informa UK Limited, 1982. 214 p. .

FRIEDMAN, Jonathan. The World Cities hypothesis. Development and Changes v. $4,1986$.

FUJITA, Masahisa; KRUGMAN, Paul; VENABLES, Anthony. The spatial economy : cities, regions and international trade Masahisa Fujita, Paul Krugman, Anthony J. Venables.ill. ; 24 cm. Cambridge, Mass.: MIT Press, 1999. xiii, 367 p. .0262062046 (hc. alk. paper).

FUJITA, Masahisa; OGAWA, Hideaki. Multiple equilibria and structural transition of non-monocentric urban configurations. Regional Science and Urban Economics v. 12, n. 2, p. 161-196, 1982.

GASCHET, F. La structure d'un espace urbain polycentrique: la métropole bordelaise. In: P.-H, Derycke (Org.). . Structure des villes, entreprises et marchés urbains. Paris: L'Harmattan, 2000.

GASCHET, Frédéric. La polycentralité urbaine. Bordeaux, Université Bordeaux IV, 2001.

GASCHET, Frédéric; LACOUR, Claude. Métropolisation, centre et centralité. Revue d'Économie Régionale \& Urbaine v. février, n. 1, p. 49 , 2002.

GASPAR, Elizete dos Santos. Os bamburrados do Tapajós. Universidade Federal da Paraíba, 1990.

GASPAR, J; GLAESER, G. Information Technology and the Future of Cities. Journal of Urban Economics v. 43, p. 136-156, 1998.

GHIO, S; VAN HUFFEL, C. Intégration économique et disparités spatiales dans I'Union européenne. Revue d'Économie Régionale et Urbaine 2 p. 249-269, 2001.

GHIO, S; VAN HUFFEL, C. L'impact des infrastructures de transport inter et intra-urbaines sur la répartition spatiale des activités dans les pays en développement. Région et Développement 11 p. 13-32 , 2000.

GOULARTI FILHO, Alcides. Melhoramentos, reaparelhamentos e modernização dos portos brasileiros: a longa e constante espera. Economia e Sociedade v. 16, n. 3, p. 455-489, dez. 2007.

GRAVIER, JeanFrançois. Paris et le désert français. Paris: Le Portulan, 1947. 414 P. .

GUERRA, Elaine Linhares de Assis. Do fordismo à acumulação flexível: uma análise sobre as mudanças nos papéis dos atores sociais relevantes.

Educação \& Tecnologia v. 5, n. 2, p. 71-75, 2000.

HARRISON, John; HOYLER, Michael. Megaregions: Foundations, frailties, futures. Megaregions: Globalization's New Urban Form? [S.I.]: Edward Elgar 
Publishing Ltd., 2014. p. 1-28. 9781782547907.

HARVEY, David. A condição pós-moderna. 4. ed. São Paulo: Loyola, 1994. 349 p. .

HARVEY, David. Os limites do capital. São Paulo: Boitempo, 2015. .

HIRSCHMAN, Albert O. Estratégia do Desenvolvimento Econômico. Rio de Janeiro: Fundo de Cultura S.A., 1961. .

HOOVER, E M. Location theory and the shoe and leather industries.

Cambridge: Harvard University, 1936. .

IBGE. Censo Demográfico. Disponível em: <https://www.ibge.gov.br>.

IBGE. IBGE / Cidades@ / Pará / Itaituba / História \& Fotos. Disponível em: $<$ https://cidades.ibge.gov.br/brasil/pa/itaituba/historico>. Acesso em: 25 set. 2019.

IBGE. Regiões de influência das cidades. Rio de Janeiro: Ministério do Planejamento Orçamento e Gestão / Instituto Brasileiro de Geografia e Estatística / Diretoria de Geociêncas / Coordenação de Geografia, 1987. .

IBGE. Regiões de influência das Cidades 2007. [S.I: s.n.], 2008a.

IBGE. Regiões de influência das Cidades 2007. Rio de Janeiro: [s.n.], 2008b.

IBGE. Regiões de influência ds cidades 1993. Rio de Janeiro: Ministério do Planejamento Orçamento e Gestão / Instituto Brasileiro de Geografia e Estatística / Diretoria de Geociêncas / Coordenação de Geografia, 2000. .

IDESP. Região de Integração Tapajós: relatório técnico. Belém: [s.n.], 2014. INDOVINA, Francesco. La città diffusa. Venecia: DAEST: [s.n.], 1990. . IPEA; IBGE; UNICAMP/IE/NESUR. Caracterização e tendências da rede urbana do Brasil: redes urbanas regionais: Norte, Nordeste e CentroOeste. Brasília: IPEA, 2001. 4 v. .

ISARD, W. The general theory of location and space-economy. Quarterly Journal of Economics v. 63, p. 476-506, 1949.

KAYSER, Bernard. L'espace non-métropolisé du territoire français. Revue géographique des Pyrénées et du Sud-Ouest v. 40, n. 4, p. 371-378, 1969.

KRUGMAN, Paul. Geography and trade. Cambridge, Mass.: MIT Press, 1992. KRUGMAN, Paul. Increasing Returns and Economic Geography. Journal of Political Economy 99(3) p. 483-499, 1991.

KRUGMAN, Paul; ANTHONY J VENABLES. Globalization and the inequality of nations. Quarterly Journal Of Economics 110 v. CX, p. 857-880, 1995.

LACOUR, C. Méthodologie de recherche et théorisation des villes. In: LACOUR, C; PUISSANT, S (Orgs.). . La Métropolisation. Croissance, diversité, fractures. Paris: Anthropos, 1999. p. 62-113.

LACOUR. C. Métropolisation ou la ville oubliée. Plan Urbain - DATAR-CGP, Mutations Economiques et Urbanisation: cinq ans de recherches et d'éxpérimentation. [S.I: S.n.], 1993.

LACOUR, C; PUISSANT, S. La Métropolisation Croissance, Diversité, 
Fractures. Paris: Anthropos, 1999. .

LACOUR. Claude; CORADE. Nathalie. La métropolisation: analyse et commandements. [S.I: s.n.], 1995.

LACOUR, Claude; PERRINI, Evelyne; AL., Et. Les nouvelles frontières de l'économie urbaine. Paris: Éditions de l'aube, 2005. .

LACOUR, Claude; PUISSANT, Sylvette. La métropolisation : croissance, diversité, fractures. [S.I.]: Anthropos, 1999. Notes bibliogr.9782717838961.

LALANNE. Aurlie; POUYANNE. Guillaume. La métropolisation, entre approfondissement et détournement Controverses économiques du début du XXIème siècle Aurélie Lalanne et Guillaume Pouyanne. [S.I: s.n.], 2011.

LAURENT. Eloi; MAURICE. Joël; FITOUSSI. Jean-Paul. Ségrégation urbaine et intégration sociale. [S.I: s.n.], 2004. Disponível em: <https://halsciencespo.archives-ouvertes.fr/hal-00972694>. Acesso em: 26 set. 2019.2110055073.

LEFEBVRE, H. A cidade do capital. Rio de Janeiro: DP\&A editora, 1999. .

LENCIONI, Sandra. Concentração e centralização das atividades urbanas: uma perspectiva multiescalar. Reflexões a partir do caso de São Paulo. Revista de Geografia Norte Grande p. 7-20 , 2007.

LENCIONI. Sandra. Concepções da metamorfose metropolitana. São Paulo: [s.n.], 2019.

LENCIONI, Sandra. Da Cidade e sua Região à Cidade-região. In: SILVA, José Borzacchiello Da; LIMA, Luiz Cruz; ELIAS, Denise (Orgs.). . Panorama da Geografia Brasileira I. São Paulo: Annablume, 2006a.

LENCIONI, Sandra. Metrópole e sua lógica capitalista atual face ao regime de acumulação patrimonial. Mercator v. $14,2015$.

LENCIONI, Sandra. Reconhecendo metrópoles: território e sociedade. In: SILVA, C.; FREIRE, D.; OLIVEIRA, F. (Org.). . Metrópole: governo, sociedade e território. DP\&A ed. Rio de Janeiro: [s.n.], 2006b.

LENCIONI, Sandra. Uma nova determinação do urbano: o desenvolvimento do processo de metropolização do espaço. In: CARLOS, Ana Fani A. (Ana Fani Alessandri); LEMOS, Amália Inês Geraiges (Orgs.). . Dilemas urbanos: novas abordagens sobre a cidade. São Paulo: Contexto, 2003.

LEOPOLDO, Eudes. Financeirização Imobiliária e Metropolização

Regional: o Alphaville na implosão-explosão da metrópole. 2018.

LEOPOLDO, Eudes. FROM URBAN-INDUSTRIAL ECONOMY TO

METROPOLITAN-FINANCIAL ECONOMY. Mercator v. 15, n. 4, p. 7-14, 2 dez. 2016.

LEVY, Jacques. Penser la ville: un imperatif sous toutes les latitudes. Cahiers d'études sur la Méditerranée orientale et le monde turco-iranien , 1997.

LIPIETZ, Alain. Fordismo, Fordismo Periférico e Metropolização. Ensaios FEE - ISSN:0101-1723 v. 10, p. 33 , 1989. Disponível em:

<http://revistas.fee.tche.br/index.php/ensaios/article/view/1381/1745>.

LIPIETZ, Alain; LEBORNE, D. Flexibilidad ofensiva, flexibilidad defensiva, dos 
estrategias sociales en la producción de los nuevos espacios económicos. In: BENKO, Georges; LIPIETZ, Alain; SALOM CARRASCO, Julia (Orgs.). . Las regiones que ganan : distritos y redes. Los nuevos paradigmas de la geografía económica. Valência: Alfons el Magnànim, 1994. 9788478221431.

LÖSH, August. The Economics of Location. Yale Unive ed. New Haven: [s.n.], 1954. .

MADIĖS, Thierry. Concurrence fiscale, competition entre collectivites locales et localisation des entreprises : modeles de jeux. Université de Paris 1, 1997.

MAPA. Exportações de soja e milho pelos portos do Arco Norte cresceram quase 54\% em 2015 - Ministério da Agricultura, Pecuária e Abastecimento. Disponível em: <http://www.agricultura.gov.br/noticias/exportacoes-de-soja-emilho-pelos-portos-do-arco-norte-cresceram-quase-54-em-2015>. Acesso em: 26 set. 2019.

MAPA. Projeções do agronegócio : Brasil 2014/15 a 2024/25, Projeções de Longo Prazo. Brasília: [s.n.], 2015.

MARCUSE, Peter; VAN KEMPEN, Ronald. Globalizing Cities: A New Spatial Order? [S.l: s.n.], 2000. 340 p. .

MARSHALL, Alfred. Princípios de Economia. São Paulo: Abril Cultural. Coleção Os Economistas, 1983. .

MARTIN, P; OTTAVIANO, G I P. Growing locations: industry location in a model of endogenous growth. European Economic Review v. 43, p. 281-302, 1999.

MARTÍNEZ TORO, Pedro Martín. La metropolización afectada por la globalización: reflexión epistemológica sobre la nueva revolución urbana.

Cuadernos de Geografía: Revista Colombiana de Geografía v. 25, n. 2, p. 77,5 jul. 2016.

MARTNER PEYRELONGUE, Carlos. El puerto y la vinculación entre lo local y lo global. EURE v. XXV, n. $75,1999$.

MARTNER PEYRELONGUE, Carlos. O Porto como Nó de Articulação entre os Âmbitos Local e Global. n. 2, p. 101-122 , 2014.

MARX, Karl. Elementos fundamentales para la crítica de la Economia Política (Grundrisse) 1857-1958. México: Siglo XXI Editores, 1980. I, II E II v. . MARX, Karl. O Capital. São Paulo: Abril Cultural, 1983. .

MATOS, R. Espacialidades em rede: População, urbanização e migração no Brasil contemporâneo. Belo Horizonte: Editora, 2005. .

MATTEO, Miguel. Teoria de Desenvolvimento Territorial. Brasília: IPEA, 2011. .

MAURICE, Joël. Économie urbaine et cohésion sociale. In: LACOUR, Claude; PERRINI, Evelyne; ROUSIER, N (Orgs.). . Les nouvelles frontières de l'économie urbaine. La Tour d'Aigues: éd. de l'Aube, 2005. p. 182.

MENEZES. Kleber. Corredor Logístico Multimodal do Arco Norte. Belém: [s.n.], 2017.

MOLLENKOPF, J H; CASTELLS, M. Dual city: restructuring New York. New 
York: Russell Sage Foundation, 1991. .

MONASTÉRIO, Leonardo; CAVALCANTE, Luis Ricardo. Fundamentos do Pensamento Econômico Regional. Economia regional e urbana: teorias e métodos com ênfase no Brasil. Brasília: IPEA, 2011. p. 43-78.

MONIÉ, Frédéric. Globalização, modernização do sistema portuário e relações cidade-porto no Brasil. In: SILVEIRA, Márcio Rogério (Org.). . Circulação, transporte e logística: diferentes perspectivas. São Paulo: Outras Expressões, 2011. p. 299-330.

MONIOS, Jason; WILMSMEIER, Gordon. Between path dependency and contingency: New challenges for the geography of port system evolution .Journal of Transport Geography. [S.I.]: Elsevier Ltd. , 1 fev. 2016 MONTE-MÓR, Roberto Luís. No Title Urbano, O Q U E É O. , 2006. MTPA, Ministério dos Transportes Portos e Aviação Civil. Corredores Logísticos Estratégicos: Complexo de Soja e Milho . Brasília: MTPA. , 2017 MYRDAL, Gunnar. Teoria econômica e regiões subdesenvolvidas. Rio de Janeiro: ISEB, 1960. .

NIELSEN, Klaus. Towards a flexible future - theories and politics? . [S.I.]:

Edward Elgar Publishing. , 1991

NORTH, D. Teoria da Localização e Crescimento Econômico Regional.

Economia Regional - textos selecionados. [S.I.]: CEDEPLAR/MINTER, 1955. p. 291-313.

OGAWA, H; FUJITA, Masahisa. Equilibrium land use patterns in a nonmonocentric city. Journal of Regional Science v. 4, p. 455-475, 1980.

OGAWA, H; FUJITA, Masahisa. Nonmonocentric urban configuration in a twodimensional space. Environment and Planning A v. 21, p. 363-374, 1989.

OLIVEIRA, Adélia Engrácia. Ocupação humana. Amazônia:

desenvolvimento, integração e economia. São Paulo: Brasiliense, 1983. p. 144-327.

OLIVEIRA, Ariovaldo Umbelino De. A mundialização do capital e a crise do neoliberalismo: o lugar mundial da agricultura brasileira. GEOUSP: Espaço e Tempo v. 19, n. 2, p. 229-245, 2015.

OLIVEIRA, Francisco De. As contradições do ão: Globalização, nação, região e metropolização. In: DINIZ, Clélio Campolina; CROCCO, Marco (Orgs.). .

Economia regional e urbana: contribuições teóricas recentes. 1. ed. Belo Horizonte: Editora UFMG, 2005. p. 33-60.

OTP. A empresa / OTP. Disponível em: <https://www.otp-sa.com.br/pt-br/otp>. Acesso em: 26 set. 2019.

PATY, Sonia. Essais sur la concurrence fiscale. Université de Lille 1, 2000.

PEGUY, P.-Y.; GOFFETTE-NAGOT, F; AL., Et. L'étalement urbain. Économie Géographique: les théories à I épreuve des faits. Paris: Economica, 2000. p. 214-276.

PERROUX, F. A economia do século XX. Lisboa: Herder, 1967. . 
PERROUX, F. Note sur la notion de pôle de croissance. Économie Appliquée v. 8, p. 307-320, 1955.

PESSANHA, Roberto Moraes. A "indústria" dos fundos financeiros: potência, estratégias e mobilidade no capitalismo contemporâneo. 1. ed. Rio de Janeiro: Consequência, 2019. 228 p. .978-85-69437-64-2.

PIORE, Michael J; SABEL, Charles F. The second industrial divide: possibilities for prosperity. New York: Basic Books, 1984 .

POLANYI, Karl. A grande Transformação: as origens de nossa época. Rio de Janeiro: Editora Campus, 2000. .

POLANYI, Michael. The tacit dimension. London: Routdedge \& Kegan Paul, 1966.

RIBEIRO. Miguel Ângelo. A complexidade da rede urbana Amazônica: três dimensões de análise. [S.I: s.n.], 1998.

RIBEIRO, Miguel Ângelo. Transformações na rede urbana: o exemplo da Amazônia. Boletim Goiano de Geografia v. 17, p. 63-72, 1997.

RODRIGUES, Jondison Cardoso. O Arco Norte e as políticas públicas portuárias para o Oeste do estado do Pará (Itaituba e Rurópolis): apresentação, debate e articulações. Revista NERA p. 202-228 , 2018. Disponível em:

<http://revista.fct.unesp.br/index.php/nera/article/view/5693/4275>.

RUIZ, Ricardo Machado. Políticas Regionais na Nova Geografia Econômica. In: DINIZ; Clélio Campolina; CROCCO, Marco (Orgs.). . Economia Regional e Urbana: Contribuições Teóricas Recentes. Editora UF ed. Belo Horizonte: [s.n.], 2006. p. 143-172.

RYCHEN, F. Le rôle des infrastructures dans le développement économique loca. Université de Aix-Marseille-II, 1998.

SASSEN, Saskia. Cities in a world economy Saskia Sassen.ill., maps; $23 \mathrm{~cm}$. Thousand Oaks, Calif.: Pine Forge Press, 1994. xv, 157 p. .0803990057 (pbk. alk. paper).

SASSEN, Saskia. The global city : New York, London, Tokyo Saskia Sassen.24 cm. Princeton, N.J.: Princeton University Press, 1991. xvi, 397 p. .0691078661 (alk. paper).

SATHLER, Douglas; MONTE-MÓR, Luis Roberto; CARVALHO, José Alberto Magno De. As redes para além dos rios: urbanização e desequilíbrios na Amazônia brasileira. Nova Economia v. 19 (1), p. 11-39 , 2009.

SAXENIAN, A. Regional Advantage: Culture and Competition in Silicon Valley and Route 128. Cambridge: Harvard University Press, 1994. .

SCHOR. Tatiana; COSTA. Danielle Pereira Da. Rede urbana na Amazônia dos grandes rios: uma tipologia para as cidades na calha do rio Solimões - Amazonas - AM. [S.I: s.n.], 2006.

SCHOR, Tatiana; COSTA, Danielle Pereira Da; OLIVEIRA, José Aldemir De. Notas sobre a tipificação da rede urbana na calha do rio Solimões, Amazonas. 2007, [S.I.]: ANPUR, 2007.

SCOTT, AJ et al. Cidades-regiões globais. Espaço \& Debates , 2001. 
SELOD, Harris. Structure des villes et ghettos urbains : le cas des EtatsUnis et de l'Afrique du Sud. Université de Paris 1, 2002.

SERFATI, Claude. O papel ativo dos grupos predominantemente industriais na ficenceirização da economia. In: CHESNAIS, François (Org.). . A

mundialização financeira: gênese, custos e riscos. 1. ed. São Paulo: Xamã, 1998. p. 334.

SMITH, Adam. A riqueza das nações: investigação sobre sua natureza e suas causas (L. J. Baraúna, Trad.) (Vol. I). São Paulo: Editora Nova Cultural (Obra original publicada em 1776), 1996. 471 p. .

SOARES, Paulo Roberto Rodrigues. Metropolização, aglomerações urbanoindustriais e desenvolvimento regional no sul do Brasil. Cadernos Metrópole v. 20, n. 41, p. 15-34, 2018.

SOLOW, Robert M. Congestion, Density and the Use of Land in Transportation. The Swedish Journal of Economics v. 74, n. 1, p. 161 , mar. 1972.

SOLOW, Robert M. Congestion Cost and the Use of Land for Streets. Bell Journal of Economics v. 4, n. 2, p. 602-618, 1973.

SOUZA, Carlos Augusto de Silva. Urbanização na Amazônia. Belém do Pará: UNAMA, 2000. .

TAYLOR, P J; LANG, R E. The Shock of the New: 100 Concepts Describing Recent Urban Change. Environment and Planning A v. 36, n. 6, p. 951-958, jun. 2004.

THÉRY, Hervé. Situações da Amazônia no Brasil e no continente. Estudos Avançados p. 37-49 , 2005. Disponível em: <https://halshs.archivesouvertes.fr/halshs-00150575>. Acesso em: 25 set. 2019.

THISSE, Jacques-François. Geografia Econômica. Economia Regional e Urbana. Brasília: IPEA, 2011. p. 17-42.

THÜNEN, Von. The isolated State. New York: Pergamon Press, 1966. .

TIEBOUT, Charles M. A Pure Theory of Local Expenditures .Journal of Political Economy. [S.I.]: The University of Chicago Press. Disponível em: <https://www.jstor.org/stable/1826343>. Acesso em: 26 set. 2019. , 1956

TINOCO, Alexandre de Carvalho. Competitividade, inovação e concentração: repensando o conceito de centralidade da Região Metropolitana de São Paulo. Universidade Federal de Minas Gerais, Belo Horizonte, 2001. $180 \mathrm{p}$.

TOURINHO, Helena Lúcia Zagury. Estrutura urbana de cidades médias amazônicas: análise considerando a articulação das escalas interurbanas e intraurbanas. Universidade Federal de Pernanbuco, 2011. 576 p.

TRINDADE JÚNIOR, Saint-Clair Cordeiro Da. Cidades médias na Amazônia oriental. Revista Brasileira de Estudos Urbanos e Regionais v. 13, n. 2 , 2011.

TRINDADE JÚNIOR, Saint-Clair Cordeiro Da. Grandes projetos, urbanização do território e metropolização na Amazônia. Revista Terra Livre p. 177-194 , 2006. 
UNITED NATIONS HUMAN SETTLEMENTS PROGRAMME. State of World's cities 2010. London ; Washington, D.C.: Earthscan, 2010. xx, 220 p. $30 \mathrm{~cm}$ p. .9781849711753.

VELTZ, P. Firmes globales et territoires: des rapports ambivalents. Économie globale et réinvention du local. Paris: Éditions de l'Aube, 1995. p. 27.

VELTZ, P. Mondialisation, villes et territoires. L'Économie d'archipel. Paris: PUF, 1996. .

WALZ, Uwe. Transport costs, intermediate goods and localized growth.

Regional Science and Urban Economics v. 26, n. 6, p. 671-695 , 1996.

WEBER, Alfred. Theory of the location of industries. Chicago: The University of Chicago Press, 1929. .

XIMENES. Tereza; CORREA. Eufrosina Maria. Itaituba, a cidade do ouro: coletânea de monografias. Belém: [s.n.], 2003.

ZAHAVI. Y. Travel characteristics in cities of developing and developed countries. [S.I: s.n.], 1980. 